\title{
THe RHETORICAL CONSEQUenCES OF MR. KEYNES: INTELLECTUALS AND THE COMMUNICATION OF ECONOMIC IDEAS
}

\author{
By \\ Larry Lepper
}

A thesis

submitted to the Victoria University of Wellington in fulfilment of the requirements for the degree of Doctor of Philosophy in Economic History

Victoria University of Wellington 2010 


\section{Abstract}

Economists interested in the communication of ideas often turn their attention to the importance of information to the economic exchange process and in so doing often focus on specific aspects of an economy. For example, economists who highlight the importance of institutions see information as an institution's lifeblood, while economists interested in technology often see information as key to technological advances and economic development. This dissertation takes a broader view of information, by analysing Maynard Keynes' The Economic Consequences of the Peace and focusing on the processes and ways in which economists successfully communicate their ideas, especially to non-economists.

Keynes was particularly effective in communicating his ideas, especially following the publication of Economic Consequences in December 1919. At this time Keynes was already regarded as an eminent economist and his book helped cement his reputation and established him as a public intellectual. Despite its success, the book was a controversial work, critics often accusing Keynes of being more a political propagandist than a serious economist. Keynes was stung by the criticism and consistently maintained Economic Consequences was a serious work of economics. The conclusion of this dissertation is that Keynes was correct in his assertion. The key to this understanding can be largely attributed to his rhetoric.

First, he provided a wide range of statistics, many from official sources, to support his central argument that if the terms of the Versailles Treaty were imposed on Germany, not only would Germany suffer, but all Europe would be reduced to an economic dark age and likely face further destructive warfare. Furthermore, his inductive and descriptive use of statistics was rhetorically successful as it provided a "factual, objective and neutral" authority for his arguments.

The second way Keynes communicated his economic arguments was with his frequent and rich use of metaphors. By using the tools of literary criticism it is demonstrated that all Keynes' arguments have an economic focus. His use of metaphors enabled him to reach a wide audience with persuasive rhetoric, unusual in a serious work of economics. 
The third indicator that Economic Consequences was a serious work of economics can be found in the economic and cultural contexts that surrounded Keynes. His writing style was influenced by his friendships in the Cambridge Apostles and Bloomsbury circles, especially those of Lytton Strachey and Virginia Woolf. These, and other influences such as Eton, Moore's philosophy and psychological realism, help explain Keynes' unique style of writing and why his explicit attempts at persuasion were often successful.

The examination presented here of Keynes' activities as a public intellectual, his use of statistics, a literary criticism of his prose, and the influences on his writing style, allow a re-reading of Economic Consequences and adds to our understanding of how economists can successfully communicate their ideas. 


\section{Acknowledgements}

A thesis with Maynard Keynes as the central character of inquiry can be a little intimidating; such is the industry that has grown up around the man and his works. Surprisingly, however, there is still much to learn from this remarkable individual. I am indebted to Dr. John Singleton for helping me realise this. Also to Dr. Charles Ferrall whose expertise in the area of literary criticism opened up a range of insights into Keynes' economics that have been surprising and revealing. Both John and Charles have been a constant source of inspiration and support as my journey of discovery has unfolded.

I am also grateful to Dr.'s Edwyna Harris and Weibe Zwaga who read and provided feedback on a later draft. Dr. Jim McAloon commented on an earlier draft chapter and Professor Emeritus Gary Hawke provided helpful comments on the seminal chapters. Thanks to both. Among the many fellow economic historians I have come to know through my association with the Economic History Society of Australia and New Zealand (EHSANZ) I am particularly grateful to those who provided comments and suggestions on papers I presented at the Sydney, Melbourne, Tokyo and Wellington Conference's'.

During my first year of study I was fortunate to have won the McComish Prize for Economic History. This enabled me to travel to the Melbourne Conference. I am grateful to the Trustees' of the Trinity College Foundation at Melbourne University and Bruce McComish, founder of the foundation, for their generous assistance and encouragement.

One of the highlights of a course of study such as this is the opportunity of working through archives of original material. I am grateful to Professor Morris Altman for his support enabling me to travel to King's College, Cambridge where the bulk of Keynes' original material is kept. The King's College Archivists' were extremely helpful in finding all the material I had identified as being important to my research.

Also thanks to Mark Tunnicliffe whose knowledge of the mysterious workings of Microsoft products is as impressive as it is helpful. This has meant a far better presented dissertation than I could have achieved on my own. To friends John Lockhart, Peter Bloor, Louise Collins and Bernie White, whose interest extended to requests to read a later draft, 
your interest has been a source of encouragement. There are many more friends and colleagues whose interest and support helped keep the motivation and spirits high. I am most appreciative, in particular to my work colleagues, who expressed interest in what I was up to right to the very end.

Of course the most closely impacted by this intense course of study has been my family and in particular my wife Christine. Without their understanding and support it would not have been possible to complete this dissertation. Many thanks.

The final word is for my good friend and colleague Professor Gordon Boyce. A number of years ago Gordon saw a capability I never thought I possessed and through his encouragement and assistance ensured I made it this far. 


\section{Table of Contents}

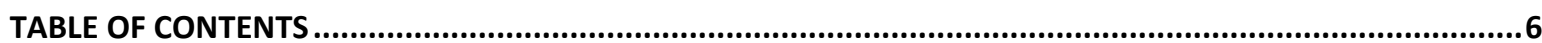

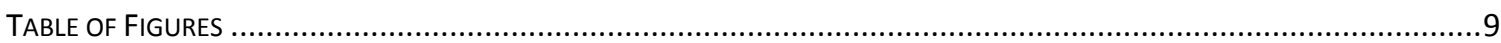

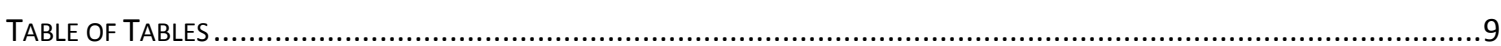

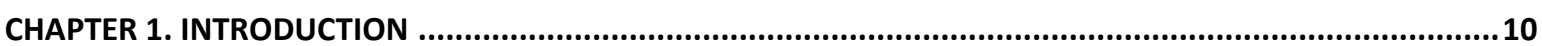

CHAPTER 2. JOHN MAYNARD KEYNES AND THE ECONOMIC CONSEQUENCES OF THE PEACE .....................16

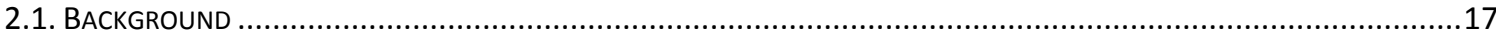

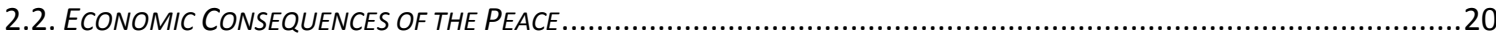

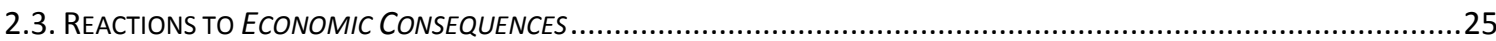

CHAPTER 3 INTELLECTUALS AND THE COMMUNICATION OF ECONOMIC IDEAS.........................................53

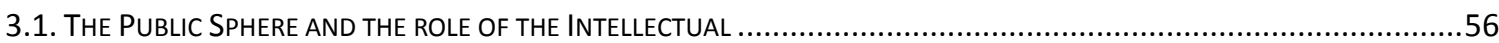

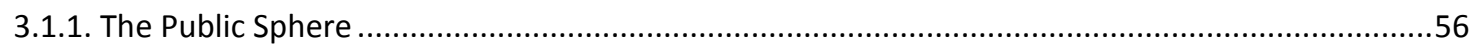

3.1.2. Towards a Definition of the Public Role of the Intellectual .......................................................61

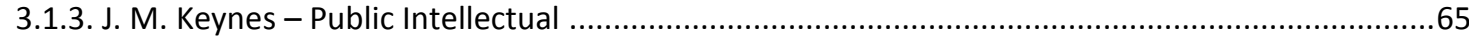

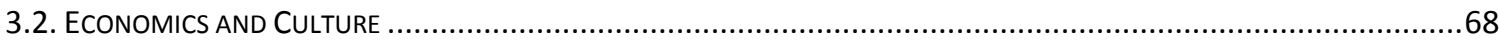

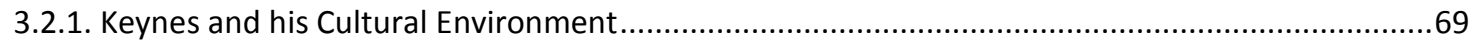

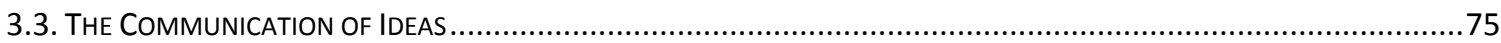

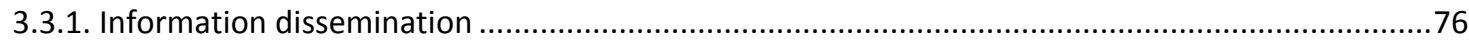

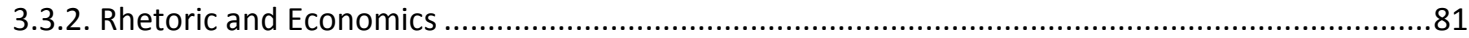

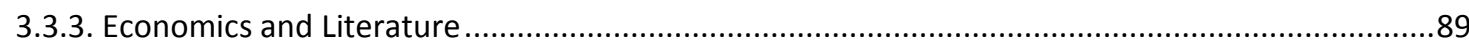

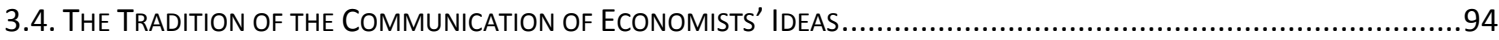

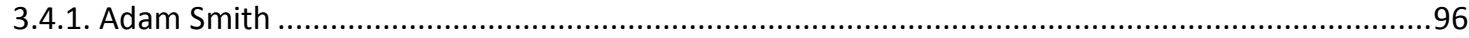

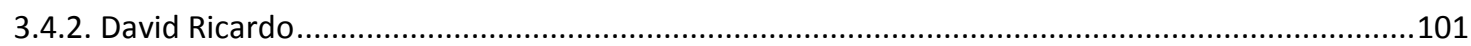

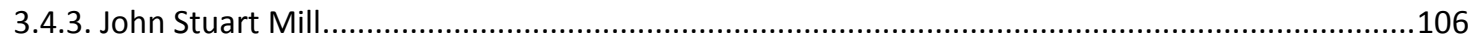

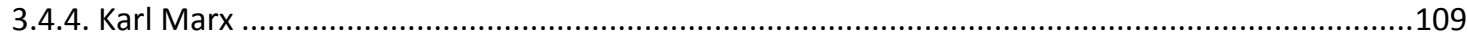

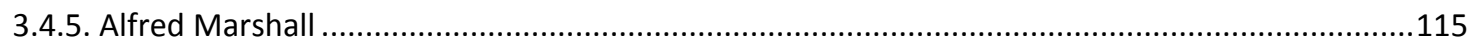

3.5. SUMMARY - INTELLECTUALS AND THE COMMUNICATION OF ECONOMIC IDEAS .................................................122

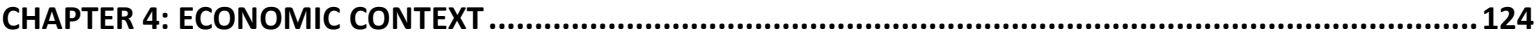

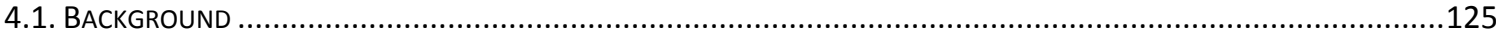

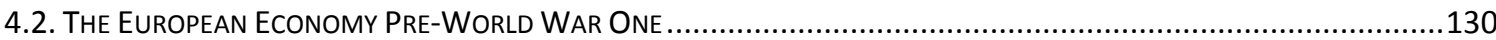

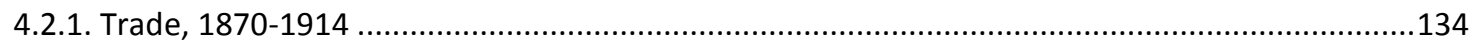

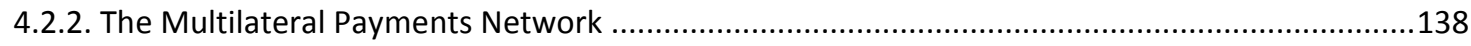

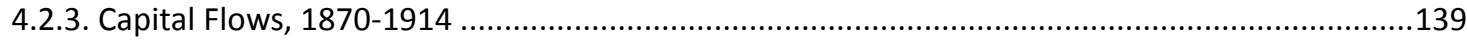

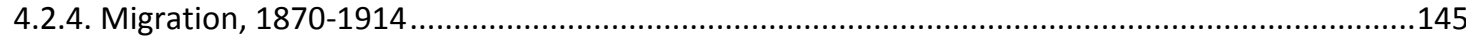

Page 6

8-Jun-11 
4.2.5. Trade in knowledge 148

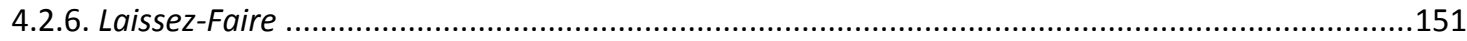

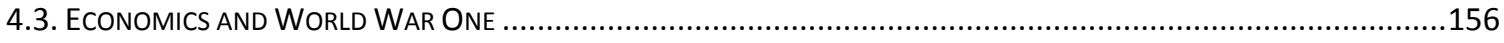

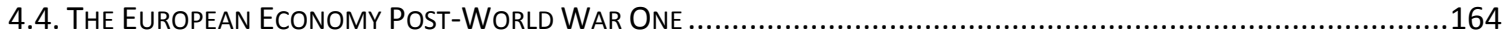

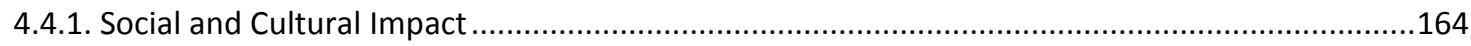

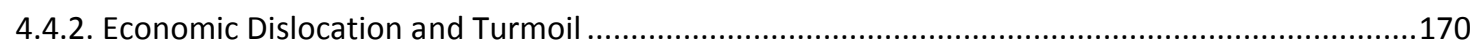

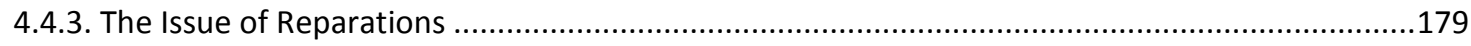

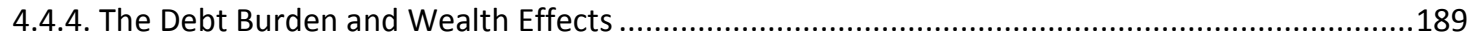

4.5. SUMmARY - THE EUROPEAN ECONOMY POST-WORLD WAR ONE ........................................................192

CHAPTER 5. KEYNES' USE OF STATISTICS IN THE ECONOMIC CONSEQUENCES OF THE PEACE ..................194

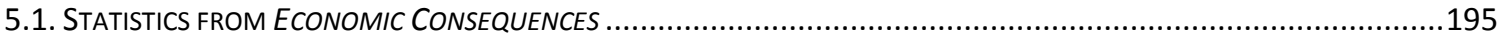

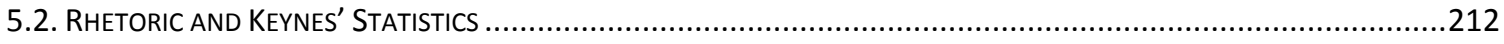

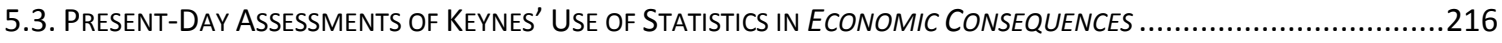

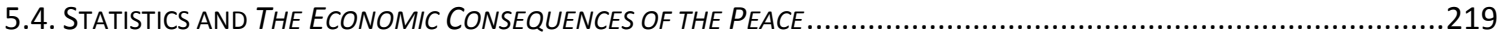

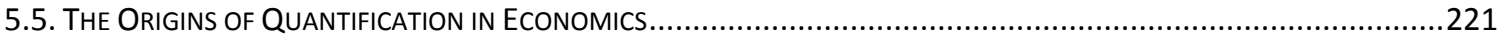

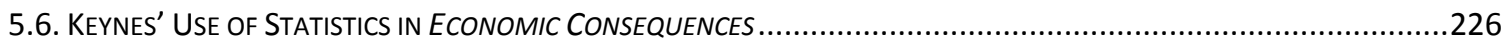

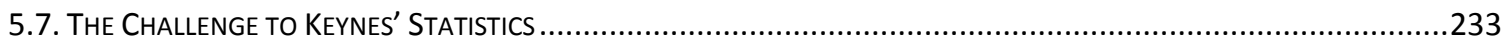

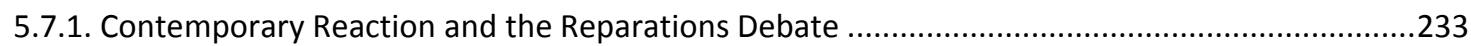

5.7.2. Étienne Mantoux: The Carthaginian Peace or the Economic Consequences of Mr. Keynes .........240

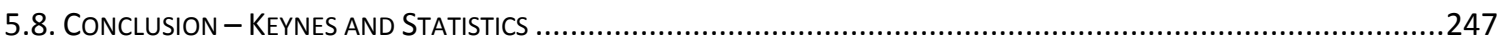

CHAPTER 6. ECONOMIC CONSEQUENCES OF THE PEACE: PROSE STYLE ...........................................248

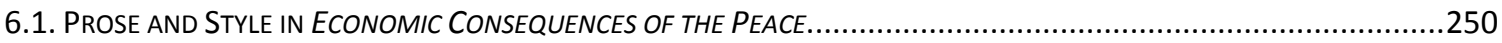

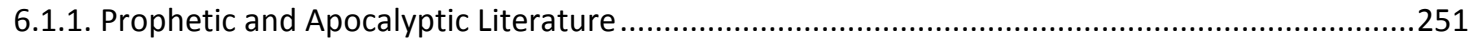

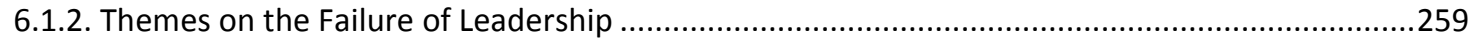

6.1.3. Other Themes: Allusions to the Classical World ...................................................................266

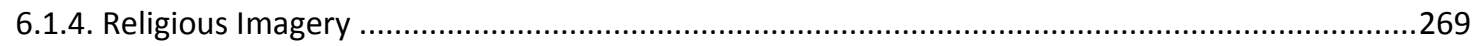

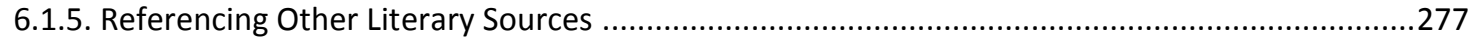

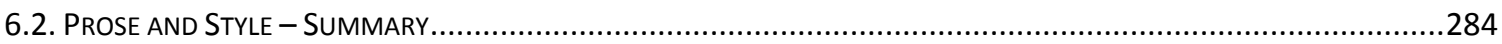

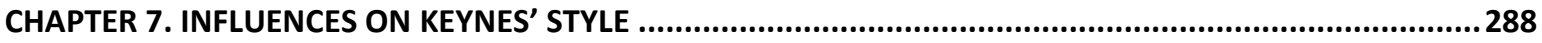

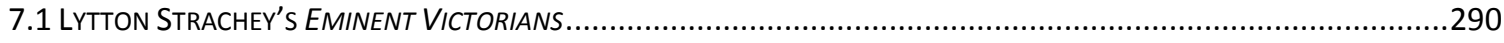

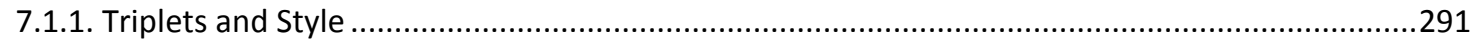

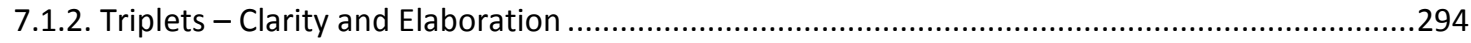

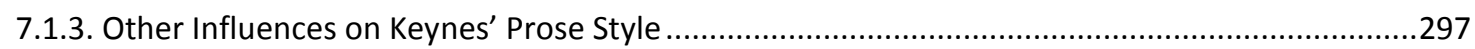

7.1.4. Innovation and Style in Keynes' and Strachey's Prose ....................................................305

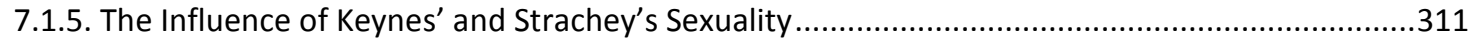

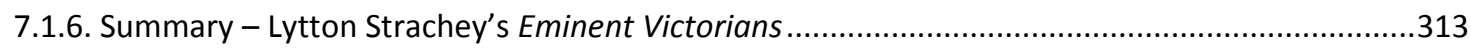




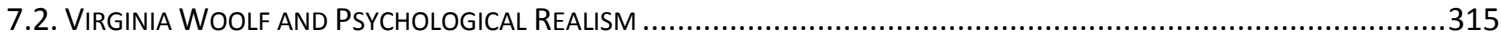

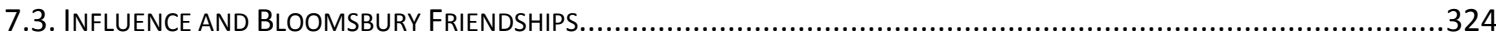

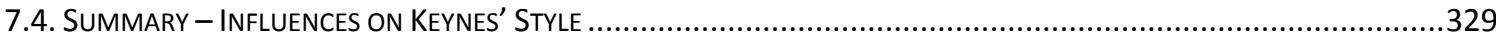

\section{CHAPTER 8. THE LEGACY OF ECONOMIC CONSEQUENCES AND OTHER SELECTED WORKS FROM THE EARLY}

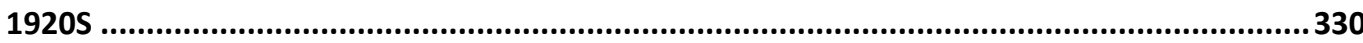

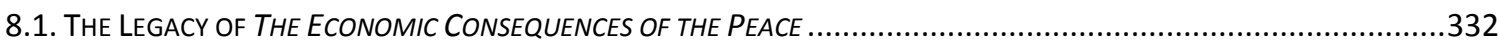

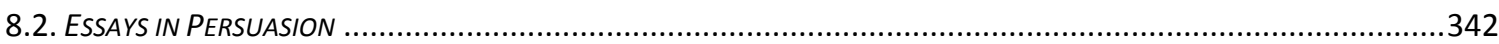

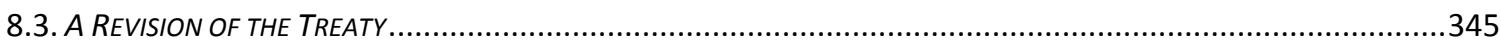

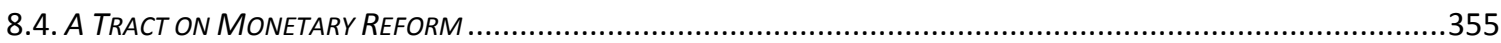

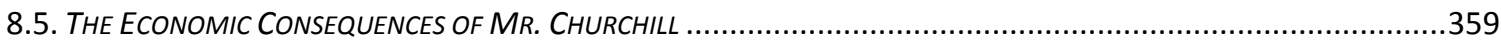

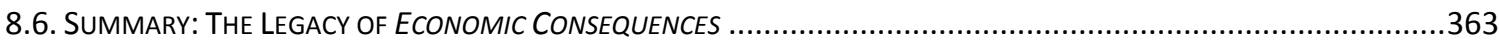

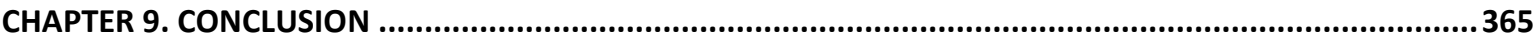

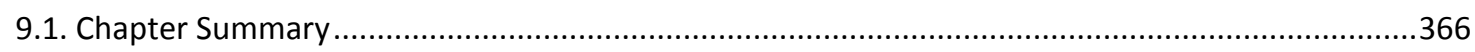

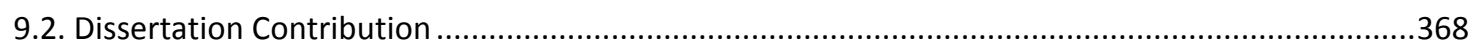

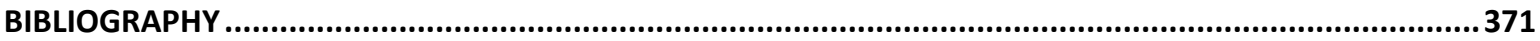

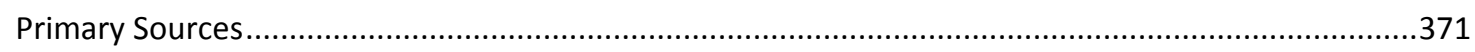

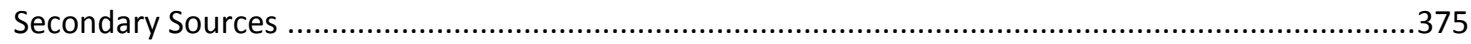




\section{Table of Figures}

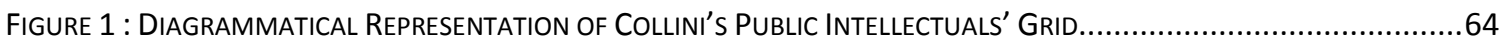

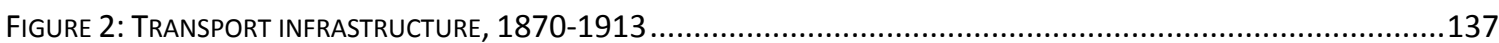

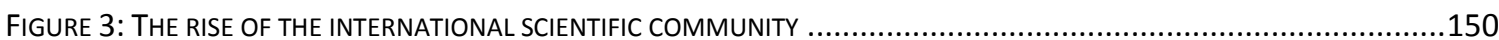

FigURE 4: EXAMPLE OF HOW KeYNES 'CUT AND PASTED' fROM MEMORANDA INTO ECONOMIC CONSEQUENCES................230

\section{Table of Tables}

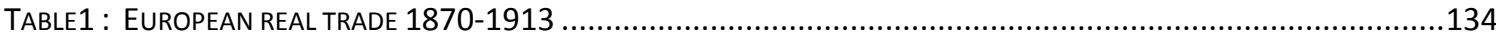

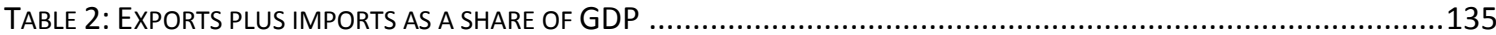

TABLE 3: DestinAtION OF ENGLISH, FRENCH AND GERMAN FoREIGN INVESTMENT .................................................144

TABLE 4: EURoPEAN EMIGRATION RATES BY DECADE (PER 1000 MEAN POPULATION) ..............................................146

TABLE 5: THE WARTIME CHANGE IN REAL GDP: 1914-1918, BY COUNTRY ...........................................................159

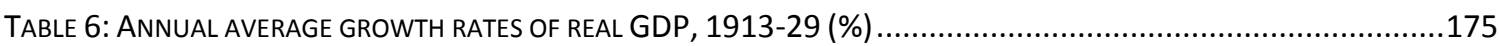

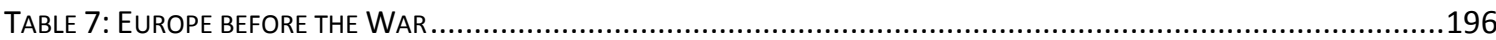

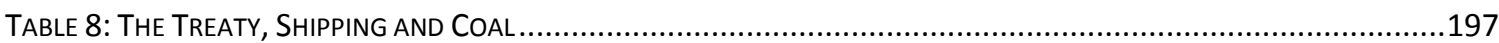

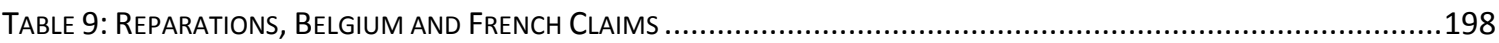

TABLE 10: Reparations; BRItISH AND Other Country ClaImS; Summary of ClaIMS .........................................199

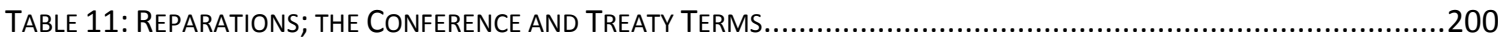

Table 12: Reparations; Germany's Capacity to Pay; Immediately TranSFerable Wealth..................................201

TABle 13: Reparations; Germany's Capacity to Pay; Property in Ceded TerRItoRies or suRRended UNDER the

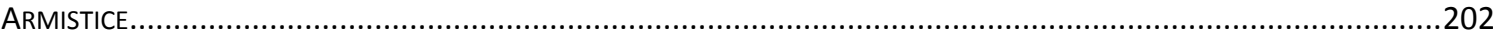

Table 14: Reparations; Germany's Capacity to Pay; Annual Payments SPREAd oVer Ten Years .........................203

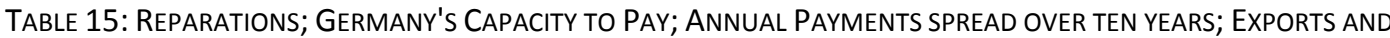

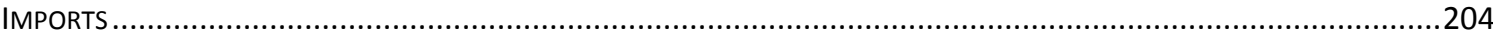

Table 16: Reparations; Germany's Capacity to Pay; Annual Payments spread over Ten Years; Summary ..........205

Table 17: Reparations; Germany's Capacity to Pay; Annual Payments spread over Ten Years; Proviso's ..........206

Table 18: The ReParation Commission AND the German Counter-Proposals................................................207

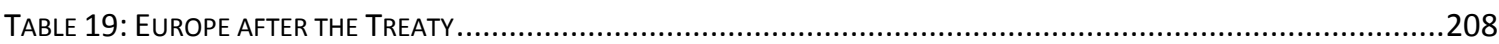

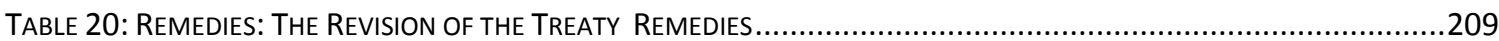

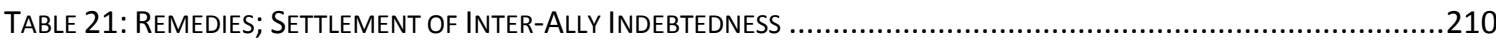

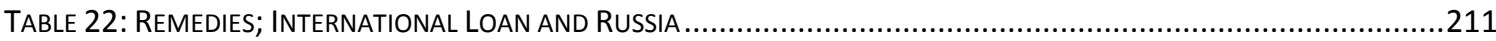

TABLE 23: EXTRACTS FROM THE WRITING OF VIRGINIA WOOLF, LYTTON STRACHEY, AND MAYNARD KEYNES FROM A PSYCHOLOGICAL REALISM PERSPECTIVE. 


\section{Chapter 1. Introduction}

Keynes enjoyed success in communicating his ideas, views and opinions. He worked tirelessly to persuade, shape and change opinions at a time of global economic uncertainty, which acted as a driver for his passionate calls for reform. He sought to explicitly persuade what he called 'inner' and 'outer' opinion. The 'inner' opinion is the élites in society who provide leadership and have the power to bring about change. However, élites in a democracy need the support of 'outer' opinion. 'Outer' opinion is the educated public who apply pressure to the élites. Keynes directed his communication efforts at both as he realised real change would only occur when 'inner' and 'outer' opinion were aligned.

Publication of The Economic Consequences of the Peace (Economic Consequences) in December 1919 brought him to the attention of a wide audience and by the time of publication of The Economic Consequences of Mr. Churchill in July 1925 Keynes had become well known in both 'inside' and 'outside' circles for his economic views. Following Economic Consequences he increasingly drew on his background, knowledge and experience to cement his place as an influential public intellectual.

Economic Consequences was written following Keynes' attendance at the Conference of Versailles as an official with the British Treasury. However, he resigned before the conference ended and returned to Britain in a state of exhaustion and bitterness at what he judged was a serious failure of leadership, believing Europe to be on the brink of economic disaster. Within six months of returning home he had written Economic Consequences. Publication, when it came, was surprisingly successful, drawing condemnation and praise in more or less equal measure and establishing Keynes' reputation as its lasting legacy. First, Keynes became a respected public figure known for having important things to say on matters of economic concern. Second, his success in communicating economic ideas can be measured from the time of the book's appearance. 
Finally, many of his ideas, though not initially accepted, in time have become accepted economic orthodoxy.

He had numerous other books, journal and newspaper articles published during the 1920s and 1930s, in addition to making public appearances where he admonished politicians, economists, and policy makers for not doing enough to deal with economic instability. He saw the long shadow of the Versailles Conference holding back a return to prosperity. Some of the issues which concerned him most included inflation, and equally damaging, deflation, disparate price levels that proved difficult and often impossible to correct and bring into a workable equilibrium, as well as unemployment, which remained high in most European countries during the inter-war period.

The range of channels Keynes used to communicate these messages is of interest because they were so broad. Economists interested in the communication of economic ideas and the importance of information to the economic exchange process often do not concern themselves with such a wide scope, but rather treat the subject as a specific element in an economy. For example, North ${ }^{1}$ and Barnard ${ }^{2}$ see information as the lifeblood of economic institutions that make up an economy. Mokyr ${ }^{3}$ on the other hand is interested in the ways in which information and knowledge lead to improvements in technology, in turn stimulating economic development. Casson ${ }^{4}$ takes a different approach and looks at the ways in which information assists intermediaries in an economy to drive efficiencies into the exchange process. While all these lines of inquiry are important for an understanding of how economies work, there is limited research around the broader communication process and how economists can best disseminate their ideas

\footnotetext{
${ }^{1}$ North, (1990).

2 Barnard, (1958).

${ }^{3}$ Mokyr, (2002 and 2010).

${ }^{4}$ Casson, (1997).
} 
to all participants in an economy. This is not to say economists choose to ignore its importance. Quite the contrary; there is an established tradition from Adam Smith through John Stuart Mill, David Ricardo, Karl Marx, Alfred Marshall to John Maynard Keynes that has explicitly used a variety of methods and media to communicate ideas, and in the process establishing these economists as public intellectuals.

The term public intellectual and the development of a public sphere in which he or she operates are both recent phenomena. Most trace the evolution of the public sphere from the time of the Industrial Revolution (1760-1830). By examining the activities of economists from the time of Adam Smith (1724-1790), whose own activities helped contribute to the emergence of the public sphere, we have some way of providing explanations for how economic ideas are communicated through their activities as public intellectuals.

The specific focus of this dissertation is Economic Consequences and how it established Keynes as a public intellectual, enabling him to successfully communicate his ideas. The research undertaken is supported by an examination of a number of components important for an understanding of how economic ideas are communicated. First for consideration is what constitutes a public intellectual. Second, there is a review of the processes that enable information to be disseminated to public spheres. Finally, is an examination of the context within which intellectuals operate and a discussion of how cultural influences play a part in successful communication.

The views of Robert Solow are of particular interest in this examination because he raises a number of difficulties associated with the communication of economic ideas. Outside the community of economists Solow is concerned that most complex economic ideas "turn to mush". ${ }^{5}$ He argues there are three reasons for this. First, the public wants simple, short explanations for what are complex economic problems. For example, when

\footnotetext{
${ }^{5}$ Solow, (1989).
} 
Keynes published A Tract on Monetary Reform, shortly after publication of Economic Consequences, he had proposed a set of reforms for the money supply system that were largely misunderstood and unacceptable to many economists, who failed to grasp what they considered were radical and unworkable ideas. Some ten years passed before Keynes' ideas were accepted by the economics profession, politicians and policy makers. What chance then for the lay public to understand Keynes' arguments?

The second difficulty Solow has with the communication of "accurate" economic ideas is the political process through which ideas are disseminated. People want certainty from those who speak with authority but many economic ideas are highly uncertain and remain open to considerable debate, especially when economic factors change rapidly and without warning. An example is the gold standard, credited with bringing stability and prosperity to international trade in the late nineteenth and early twentieth centuries; its reintroduction in the 1920s can only be described as disastrous for a world disrupted and changed by the events of World War One. Many economists now accept the gold standard was a major contributor to the depth and longevity of the Great Depression, although it had underpinned the first great wave of economic globalisation from around 1870 to 1913.

Finally, Solow argues that problems associated with the communication of economic ideas come from within the economics profession itself. Standards other disciplines have for developing and testing theories in a robust manner often do not exist in the same way for economists. Solow uses the example of the development of regression tests, which when applied to economist's' models often provide the result the researcher would like to see. This is not to imply that the profession is deliberately unethical, for there are reputable ways of examining and testing many of its theories.

Some argue it is not possible to effectively communicate the complex ideas of scientific disciplines such as economics. However, this is similar to a doctor telling their patients they cannot tell them why they are dying because the explanation will be too complex for them to understand. Keynes would have understood the analogy well and 
would no more accept it than accept the notion there is little point in communicating economic ideas to the public. To bring about any real reform or change requires the message to be understood by the public, in the same way in which élites need to understand the message in order to effect change.

This dissertation is structured in a way that component parts of the communication process are examined before a detailed analysis and literary criticism of Economic Consequences is undertaken. In other words an examination of what is meant by the communication of economic ideas is undertaken before examining how economic ideas are communicated. The first inquiry is a descriptive examination of Economic Consequences, including reactions to the book so there is a foundation for an analysis of how Keynes communicated his ideas. Second, what is meant by the term public intellectual is examined so it can be better appreciated the part they play in the communication process. Third, the importance of cultural and environmental influences to the communication process is discussed as this involves understanding the audience an economist has to reach out and communicate to. Fourth, the variety of ways in which ideas are communicated is examined, with an emphasis on literary communication. While Keynes utilised any media he found useful, in reality most of his communication was in a literary form, which forms the scope for this inquiry. The final component of the foundation inquiry focuses on the economic context within which Economic Consequences was written. Keynes maintained his book was a serious work of economics and this inquiry into the extraordinary set of economic circumstances, which underpins Economic Consequences, helps confirm Keynes' claim and demonstrates that economic solutions are dependent on context.

Following this examination of what is meant by the communication of economic ideas, three chapters provide an analysis of what Keynes wanted to communicate so it is possible to demonstrate Economic Consequences was, as Keynes claimed, a serious work of economics. The first of these chapters, Chapter Five, deals with how Keynes used statistics descriptively and rhetorically in Economic Consequences. Chapter Six is a literary criticism of Keynes' prose, confirming that, rather than writing political propaganda as his Page 14 
critics accused him of doing, everything he wrote had a serious economic message.

Chapter Seven examines a number of influences on Keynes' writing style as this provides a number of clues as to how his unique writing style was so successful. The final chapter of inquiry examines the legacy of Economic Consequences and provides a discussion of some of Keynes' selected works from the early 1920s, as he built on his reputation as a public intellectual and demonstrated the ways in which he continued to successfully communicate his ideas. 


\section{Chapter 2. John Maynard Keynes and The Economic Consequences of the Peace}

Keynes' attendance at the Versailles Conference as an official representing the British Treasury was cut short when he tendered his resignation and returned to England in a dispirited frame of mind with what he believed was the failure of the Allied leaders to honour pledges made to Germany in return for her surrender. He believed the terms of the Treaty to be imposed on Germany and her allies were vindictive and vengeful and would mean economic ruin for all of Europe for years to come.

On returning home he immediately began writing a book of his experiences and views of the Conference. It took Keynes six months to write and when it was published during December 1919, it immediately became a best seller. While Keynes maintained this was a serious work of economics many of his critics judged him to be a pro-German sympathiser more interested in writing political propaganda than turning his attention to serious economic analysis. Keynes let much of the criticism pass, but he was stung by the criticism his book was more about politics than economics. Subsequently he spent the next several months responding and defending himself against the more considered criticism. 


\subsection{Background}

Since its publication Economic Consequences has attracted controversy ranging from extreme criticism to extreme praise. ${ }^{1}$ However, most acknowledge it has had a significant impact on both the events and literature of the twentieth century and is rated as one of Keynes' most important works. For example Skidelsky rates it as his 'best book.' ${ }^{2}$ Blaug argues this was Keynes' most carefully constructed and persuasive book and made him a household name. ${ }^{3}$ The economist and contemporary of Keynes, Joseph Schumpeter remarked that the book 'met with a reception that makes the word success sound commonplace and insipid. ${ }^{4}$ In Britain and the United States the book sold 60,000 copies in the first two months and over 100,000 copies by the end of July 1920. Translations in other languages followed: German, French, Dutch, Danish, Swedish, Italian, Spanish, Romanian, Russian, Japanese, and Chinese. Extracts and abbreviated versions were widely available. One historian described its role in the formation of opinion as 'epoch-making. ${ }^{5}$

Yet despite the widespread acknowledgement of its significance Economic Consequences remains controversial as many see its political arguments as more important than its economic content. In a review for The American Economic Review in June 1920, Clive Day stated that while the book

is written by an economist on an economic subject, it is not, and cannot have been designed to be, a contribution to economic literature. It is a political tract like the writings of Daniel Defoe and the British Merchant on the Peace of Utrecht, two hundred years ago,

\footnotetext{
${ }^{1}$ Keynes, (1919).

${ }^{2}$ Skidelsky, (1983, p. 384).

${ }^{3}$ Blaug, (1994, p. 1207).

${ }^{4}$ Moggridge, (1992, p. 335) from Schumpeter, (1946, p. 499).

${ }^{5}$ Moggridge, (1992, p. 335) from Lentin, (1984, p. 141).
} 
it is meant to rouse public interest and to force political action, and to reach that end it follows methods, which are far removed from those of the strict scientist. ${ }^{6}$

Smithies, writing fifty-two years later, also supports the view that the book is 'an amazing polemical performance. One is still almost overwhelmed by the vividness of phrase, the biting satire, and the wealth of allusion. ${ }^{77}$ Like Day, Smithies takes issue with the book being held up as a work of 'good' economics. He argues that the book's appeal is more emotive than analytical with 'most of the analytical structure [being] implicit rather than explicit' and 'Keynes' argument against the Treaty [as] political and moral, rather than economic. $^{8}$ While Keynes usually provided well sourced statistics to support his arguments, Smithies is critical of Keynes for having no economic analysis to show, though harsh, why the terms of the Treaty could not be carried out.

For other commentators, to treat this work as an economics text is to miss the point. For example, Harrod argues that Keynes intentionally designed the book to be polemic. He argues, 'it was composed in two months in a white heat of passion, immediately after the events (of the Paris Peace Conference).' In Harrod's view the book sought to influence public opinion as 'Europe was disintegrating and [needed to] be saved. ${ }^{9}$ Rather than being an analysis of the economics of the Treaty, Harrod argues Keynes' aim was to tell his public, the Peace Treaty was an act of wickedness and folly, though not because the main parties to it, Wilson and Lloyd George, were themselves wicked. Rather, Keynes' vivid character sketches were designed to show how personal weaknesses lay at the heart of everything that was wrong with the Treaty:

\footnotetext{
${ }^{6}$ Day, (1920, p. 301).

${ }^{7}$ Smithies, (1972, p. 471).

${ }^{8}$ Smithies, (1972, p. 473).

${ }^{9}$ Harrod, (1951, p. 259).
} 
The disillusion was so complete, that some of those who had trusted most hardly dared speak of it. Could it be true? They asked of those who returned from Paris. Was the Treaty really as bad as it seemed? What happened to the President? What weakness or what misfortune had led to so extraordinary, so unlooked-for a betrayal? Yet the causes were very ordinary and very human. ${ }^{10}$

While many economists share Harrod's view that Economic Consequences 'takes its place as one of the finest slices of polemic in the English language,' many of these same economists see the book as far more than mere political propaganda. ${ }^{11}$ For example Moggridge argues it is

several books in one: a trenchant political pamphlet attacking the morality of the Peace Treaty in the light of the understandings that had existed at the time of the Armistice; a technical discussion of the economic provisions of the Treaty; an illuminating, if nostalgic, discussion of relations between nations and classes before 1914; and a series of proposals for dealing with European problems as they existed in the second half of $1919 .^{12}$

The controversy that greeted the publication of Economic Consequences has continued to the present day with economists and non-economists remaining divided on the books central message.

\footnotetext{
${ }^{10}$ Keynes, (1919, pp. 35-36).

${ }^{11}$ Harrod, (1951, p. 258).

12 Moggridge, (1992, p. 324).
} 


\subsection{Economic Consequences of the Peace}

If, as Moggridge argues, Economic Consequences is several books in one, Keynes intended the central message be economic. He states,

my purpose in this book is to show that the Carthaginian peace is not practically right or possible. Although the school of thought from which it springs is aware of the economic factor, it overlooks, nevertheless, the deeper economic tendencies which are to govern the future. The clock cannot be set back. You cannot restore Europe to 1870 without setting up such strains in the European structure and letting loose such human and spiritual forces as, pushing beyond frontiers and races, will overwhelm not only you and your 'guarantees', but your institutions, and the existing order of society. ${ }^{13}$

Before deciding to write a book about the Peace and the longer the conference went on, Keynes became increasingly unsettled about the economic impact of what the Germans and their allies were being asked to agree to. This unease prompted him to consider leaving the Conference and resigning as a Treasury official. Austen Chamberlain had written to Keynes on 21 May 1919 seeking to convince him to remain:

Bradbury will write to you as to the other members of the staff but I could not leave to him the expression of my strong feeling that a continuation of your services is for the present of great importance in the public interest, nor can I refrain from making my personal appeal to you to continue your help until the situation is more clearly defined. ${ }^{14}$

Following his decision to resign and leave the conference, Keynes replied to Chamberlain on 26 May 1919:

\footnotetext{
${ }^{13}$ Keynes, (1919, p. 33).

${ }^{14}$ Keynes, (CW, XVI, p. 459).
} 
I appreciate your letter very much, just as I have had good reason to appreciate my treatment by the Treasury all through; and if the only grounds for leaving were the need for rest and the desire to get back to my own work, I could not resist your appeal. But that is not the position. I was so anxious to leave this conference on general grounds that I did not like to make too much fuss about my reasons arising out of disagreement with the policy which is being pursued here. .... I cannot express how strongly I feel as to the gravity of what is in front of us, and I must have my hands quite free. I wish I could talk to you about the whole miserable business. The Prime Minister is leading us all into a morass of destruction. The settlement which he is proposing for Europe disrupts it economically and must depopulate it by millions of persons. The new states we are setting up cannot survive in such surroundings. Nor can the peace be kept or the League of Nations live. $^{15}$

A month later Keynes was home, writing what was to become The Economic Consequences of the Peace. In a letter to his mother he wrote: 'On Monday [23 June] I began to write a new book ... on the economic condition of Europe as it now is, including a violent attack on the Peace Treaty and my proposals for the future. ${ }^{16}$

Clearly Keynes' intention was to write about Europe and how the Treaty would affect its economic future. His comprehensive analysis of the economic consequences he foresaw for Europe, if the terms of the Treaty were imposed, provides a revealing insight into how significant he considered economics to be for the future welfare of Europe. While he does focus on political issues, especially Chapters I (Introduction), II (Europe Before the War) and III (The Conference), each chapter deals with specific economic issues that lay a foundation for the chapters that follow, so that a continuous economic theme

\footnotetext{
${ }^{15}$ Keynes, (CW, XVI, pp. 459-460).

${ }^{16}$ As cited in Skidelsky, (1983, p. 376), from a letter discovered in Harrod's papers, now at King's College, Cambridge.
} 
runs throughout. When raising an economic issue, Keynes supports his argument with statistics, figures and financial analysis.

He finished the book with a set of suggested remedies (Chapter VII - Remedies) to head off the economic apocalypse he foresaw. They included a revision of the Treaty, a cancellation of inter-Allied debts, an international reconstruction loan for Europe, which would assist currency stabilisation and a change in the relations between Central Europe and Russia. He did admit that his suggestions were tentative and probably inadequate for the tasks at hand. ${ }^{17}$ His proposals focused on a significant reduction in Germany's economic obligations to the Allies and suggested 'the amount [of the payments] to be made by Germany in respect of Reparation and the costs of the Armies of Occupation [might] be fixed at $£ 2,000$ million. ${ }^{18}$ To meet this sum, the immediate transfer of ships, property in ceded territory and the like should be reckoned at $£ 500$ million and the balance of $£ 1,500$ million should be paid without interest in thirty instalments of $f 50$ million beginning in 1923. He argued, 'Germany would meet these instalments as she saw fit, any complaints about non-fulfilment being a matter for the League of Nations. ${ }^{19}$ There would be no further expropriations of German private property except to meet private debts abroad, and, as far as coal was concerned, the Treaty revision would eliminate German deliveries to everyone except France, where they would be limited and lapse if Germany lost Upper Silesia. The costs to Germany of the Saar arrangements would be substantially reduced. ${ }^{20}$ Moreover, Germany, Poland and the successor states of the

\footnotetext{
${ }^{17}$ Keynes, (1919, p. 236).

${ }^{18}$ Keynes, (1919, p 245).

${ }^{19}$ Moggridge, (1992, p. 334).

${ }^{20}$ The primary cost to Germany of the Saar arrangement was the loss of coal, which had to be shipped to France for a fifteen-year period, from 1920 to 1935. There were also costs associated with administration of this arrangement. The League Council (of the League of Nations) established a five-member commission to administer the Saar Basin, a geographically folded, minerally rich, ethnically German, economically important, industrialised area. At the end of the fifteen-year period the League was to administer a ...Footnote continued on next page...
} 
Austro-Hungarian and Turkish Empires would be required to join a free trade area for a decade. Keynes wanted to see Germany's economic life restored and he called for 'Germany to take up again her place in Europe as a creator and organiser of wealth for her Eastern and Southern neighbours.' ${ }^{21}$

The revision of inter-Allied indebtedness would see Britain renounce her share of reparations in favour of Belgium, France and Serbia and the complete cancellation of warrelated, inter-governmental debts amongst the Allied and Associated countries. Under such a scheme, the nominal losers would be Britain and the United States, the only creditors, with the American losses at around $£ 2,000$ million and Britain's $f 900$ million (of which $f 550$ million represented loans to Russia), but as in earlier papers he 'justified' the result in terms of relative sacrifices incurred during the war itself. Keynes acknowledged the loan proposal carried with it a weighty list of objections, given the existing policies of the European governments. He argued,

If I had influence at the United States Treasury, I would not lend a penny to a single one of the present governments of Europe. They are not to be trusted with resources. ${ }^{22}$

Nevertheless, Keynes argued the United States should point the way by having a plan and conditions on which the US would give aid for the renewing of economic life to Europe. Keynes proposed a loan to Germany of $£ 200$ million for food and raw materials, plus a guarantee fund of a similar size to support currency stabilisation. The United States, Britain and the European neutrals would provide the loan, while the guarantee fund would be the responsibility of all members of the League. The loan was to carry the best

referendum for the Saar citizens to decide whether to become part of Germany or join France. When the referendum was held the Saar citizens voted to become part of Germany. Krasno, (2004, p. 226).

${ }^{21}$ Keynes, (1919, p. 276).

${ }^{22}$ Keynes, (1919, p. 267). 
security available and 'its repayment would rank ahead of all internal or international governmental debts or obligations of the recipients. ${ }^{23}$

Keynes' economic arguments were, argues Skidelsky, 'a personal statement unique in twentieth-century literature' and in this one work Keynes was 'staking the claim of the economist to be Prince.' ${ }^{24}$ Whether his readers saw it this way and whether he was successful in disseminating his main ideas remains controversial. An examination of reactions to the book when it was first published highlights just how divisive Keynes' views were.

\footnotetext{
${ }^{23}$ Moggridge, (1992, p. 334).

${ }^{24}$ Skidelsky, (1983, p. 384).
} 


\subsection{Reactions to Economic Consequences}

Contemporary reactions to Economic Consequences were immediate, widespread, divided in opinion, and with little consensus emerging as to what the core message was. Of the books-in-one suggested by Moggridge, only two were of real interest to Keynes' peers, the politics and the economics. Of the two, many concerned themselves with Keynes' political discussion and observations. For example Johnson argues, 'Keynes' circle of English friends praised the book's brilliance and with their taste for gossip savoured the personality sketches with delight. ${ }^{25}$ Carl Melchior, who had refused offers to become Minister of Finance in the German Government and returned to banking business in Hamburg, wrote to Keynes on 19 December 1919:

I have read your book right through last night, and I must confess that I am still under the profound impression it has made on me. It is not only the contents, the relating of material facts, the way you judge them and your proposals for healing: it is the refined and magnetising art of representation that gave me the feeling of reading lugubrious, bewildering and lofty drama of which - fortunately or unfortunately only the first acts may be over. I can heartily wish that your book may be a landmark for a new development in the post war history. ${ }^{26}$

After receiving a pre-publication copy, the British Chancellor of the Exchequer, Austen Chamberlain, sent a long letter to Keynes on 22 December 1919, marked 'Confidential,' which expressed both concern and praise:

My dear Keynes,

\footnotetext{
${ }^{25}$ Keynes, (CW, XVII, p. 10).

Elizabeth Johnson is the editor of a number of the volumes that make up The Collected Writings of John Maynard Keynes. Where there is editorial comment made in The Collected Writings, reference has been made to Johnson.

${ }^{26}$ C. Melchoir to J.M. Keynes, 19 December 1919, King's College Archives, JMK/EC/2/1/65.
} 
..You say that you will be interested to know what I think of [your book], so you must not blame me if I obtrude criticism! Frankly I am sorry that one who occupied a position of so much trust and consequence in the British Delegation in Paris should feel impelled to write in such a strain of the part his country played in the peace negotiations; and though I readily recognise that you have betrayed no confidence in the sense of writing anything which, as far as information goes, might not have been written by any intelligent observer in Paris, yet I cannot help fearing that our international course will not be made easier by such comments from a late public servant.

But having said so much - and I could not say less on this topic - I must add that I am full of admiration for a brilliant piece of work. I read your description of the conference with malicious pleasure, especially what concerned the President, whose picture you have drawn with the brush - shall I say? - of a Sargent, who is always surprised that his brush reveals secrets which cause the observer to dislike or despise his sitter. ...

I wish that I thought your reasoning as to Germany's capacity to pay, and your economic picture of the state of Europe, less accurate than I do. I think you a little too pessimistic, but in the main I believe you to be right. ... I differ from you as to the moral relationship (if I may use the phrase) of the Treaty to Wilson's Fourteen Points and three speeches. That Wilson should have submitted this orgy of rhetoric to Germany without consultation with his associates was characteristic and deplorable ... It follows necessarily that Wilson's declarations could not be taken as a legal contract. ... Seriously, I am sorry that you should impute bad faith to all the Allied negotiators. The position is difficult enough, the need for some world agreement as to a solution is urgent enough, and I think your argument would have been more persuasive and compelling if you could have found it in your heart to 
base your case entirely on the economic facts and to omit the moral denunciations. $^{27}$

Chamberlain's comment that Keynes' argument would have been more persuasive and compelling if he had stuck to economic arguments goes to the heart of how an economist can be persuasive and convincing when communicating ideas. For example could Keynes have communicated his ideas just as effectively without the political sketches or elevated rhetoric that seemed to resonate so successfully with readers? It would have been interesting to know how Chamberlain thought Keynes could have been more compelling and persuasive if he had just kept to the economic arguments.

Keynes replied to Chamberlain, 'apart from the inevitable oppositions, I am delighted that you find so little to blame.' Keynes did, however, take issue with the criticism that he should have omitted the 'moral denunciations.' He felt it was his obligation to tell the truth as he saw it and posed the question, 'Would you not agree that one who holds such a view ought to express it? ${ }^{28}$ But this approach did not meet with such a balanced response from other colleagues and contemporaries. For example, Harrod wrote, the book 'incurred great odium in official circles' and lost Keynes influence with the Treasury for ten years. ${ }^{29}$ Two of Keynes' Treasury colleagues, Leith-Ross ${ }^{30}$ and Grigg, ${ }^{31}$ subsequently wrote accounts of their Treasury careers and their comments tend

\footnotetext{
${ }^{27}$ Keynes, (CW, XVII, pp. 10-11).

${ }^{28}$ Keynes, (CW, XVII, p. 13).

${ }^{29}$ Harrod, (1951, pp. 280-83).

${ }^{30}$ Sir Frederick William Leith-Ross (1887-1968) was first assigned to the finance division of Treasury in 1909. In 1911 he was appointed a private secretary to the Prime Minister, Herbert Asquith, but returned to the Treasury in November 1913. He enjoyed a long career with the Treasury, until 1932 when he was appointed chief economic advisor to the government. He subsequently served in a number of government and private business roles right up to his death in 1968. Source: Middleton, Roger, (ODNB, 2004, 34489)

${ }^{31}$ Sir Percy James Grigg (1890-1964) joined the Treasury in 1913 following his place as first in the examination for entrance to the administrative class of the civil service. For most of his working life Grigg ...Footnote continued on next page...
} 
to support Harrod's view. Writing of the reparations terms Leith-Ross maintained that 'the position was not helped by the publication of Maynard Keynes' vitriolic book on the Economic Consequences of the Peace. Britain became enemy No. 1 in the view of the French Press and of many French people. ${ }^{32}$ Grigg, in his reflections, says of Economic Consequences:

I have often thought - and the view has recently been developed in a study by M. Etienne Mantoux - that this book had a great and deplorable effect in causing the Americans to withdraw into their shell and in creating the legend of the 'Carthaginian Peace' which was so skilfully exploited by Hitler. And I believe that Keynes himself admitted before he died that it, too, had consequences consequences, which he had neither foreseen nor desired. ${ }^{33}$

If it was true Keynes later had regrets, at the time of publication Keynes only expressed the view he had been misunderstood, especially by many Americans. One American Treasury official objected that 'he attacks everything sound or established or generally accepted ... he is utterly irresponsible. He doesn't care how much harm he does. ${ }^{34}$ Expressions such as these took people's focus from the views Keynes intended. However, as Johnson argues, with portraits such as those of President Wilson, Keynes had handed the opponents of the President some 'red-hot political ammunition. ${ }^{35}$ Keynes had written a longer version of the preface for Economic Consequences in November 1919, which

worked in government appointed roles, both inside and outside the Treasury. Toward to end of his life he also held a number of directorships in private commercial firms. Source: Oxbury, H. F., (ODNB, 2004, 33585)

${ }^{32}$ Leith-Ross, (1968, p. 61).

${ }^{33}$ Other scholars have made this argument but it is an unconvincing one. There exists little substantial evidence that Keynes ever regretted what he had argued in Economic Consequences. It appears to be more a case of wishful thinking on the part of Keynes' most vociferous critics that he somehow would have had a “Damascus Road" experience.

${ }^{34}$ Holroyd, (1995, p. 464).

${ }^{35}$ Keynes, (CW, XVII, p. 42). 
contained a second paragraph acknowledging the mitigating circumstances of the President's illness and emphasising his basic sincerity, which may have served to placate some of the more severe reaction to his book, but Keynes had not used it. The appearance of the American edition in advance publication of three excerpts in the New Republic, had not helped, especially as the first excerpt was of Chapter Three with its account of Wilson, the bamboozled Presbyterian. As a result the book was met with bitterness by the American press, something Keynes 'marvelled' at and put him on the defensive. Keynes wrote to Paul Cravath, the American lawyer who had been his colleague on the InterAllied Council for War Purchases and Finance:

I suppose the American edition of my book has now appeared. I am rather sorry in many ways that extracts from it have come out in advance, although I dare say it is necessary for publicity reasons. The book is intended by its author to be taken very much as a whole, and its proper appreciation is very much prejudiced in his humble opinion by the perusal of partial extracts. The due and proper balance of the feelings and judgments it seeks to convey, are seriously upset by undue concentration on the book's flashier parts. ${ }^{36}$

But, as Johnson points out, the 'flashier parts' stuck, so in defence of his political and economic views, Keynes to some degree moved to qualify and soften his original judgment of the President. ${ }^{37}$

While reactions in some quarters were hostile and bitter, other contemporaries of Keynes were full of praise. Eddie Marsh, private secretary to Winston Churchill, wrote to Keynes:

My dear Maynard

\footnotetext{
${ }^{36}$ Keynes, (CW, XVII, p. 43).

${ }^{37}$ Keynes, (CW,XVII, p. 43).
} 
Winston asks me to thank you very much for sending him your book. .... I got it on Saturday and read it Sunday, I really must congratulate you on a most brilliant piece of work. The substance of it filled me with deepest gloom, but the treatment is a triumph, it is as easy to read as the best novel, and supremely lucid, it never occurs to me that the subject is Technical and might in other hands be stodgy. ${ }^{38}$

Other politicians, and those who mixed in political circles, also commented on the book. What is striking about reactions from within political circles and from politicians themselves is the degree to which Keynes' views carried with them a significant "air" of authority, even where there was disagreement with his views. For example, Lord Parmoor stated in the House of Lords:

There is [a] quotation I should like to make [from] ... Mr. Keynes, who is very well known to the Government ... [on the subject of] relief measures. ... "The situation is one which cannot be solved merely by measures of relief, by the mere distribution of food to populations that cannot pay for it. There is only one adequate measure which will meet the menace of the situation and that is to re-establish all the processes of normal economic life among the populations concerned. They must be enabled to get back to normal work and support themselves. No other solution can be adequate." ${ }^{39}$

Herbert Samuel, in a speech to the House of Commons on the question of inter-Allied debt, stated that 'we hear men like Mr. Keynes talking about cancelling the debt of Britain to America.' In this case Samuel used Keynes' name and reputation to support his own

\footnotetext{
${ }^{38}$ Eddie Marsh to J.M. Keynes, 15 December 1919, King's College Archives, JMK/EC/2/1/27.

${ }^{39}$ Hansard/House of Lords/22 December 1919.

Baron Parmoor (Charles Alfred Cripps, 1852-1941) established a large and lucrative law practice at the parliamentary bar, until entering parliament. In 1890 he became a queen's council and was appointed attorney-general to three successive Princes of Wales from 1895 to 1914 . Source: Williamson, Philip, (ODNB, 2004, 32629).
} 
arguments for the cancellation of debts owed to America following the war. ${ }^{40}$ Reference to Keynes' name and reputation was again made in the House of Commons when George Roberts addressed the house:

High prices, as the right hon. Gentleman opposite (Mr. Asquith) has stated, is a world phenomenon ensuing from the destruction of war, which has occasioned a real shortage. When there is a real shortage, as Professor Keynes has put it, the profiteer is a consequence, and not a cause, of the high prices. ${ }^{41}$

Addressing the House of Lords on the subject of reparations Lord Parmoor explicitly referred to the air of authority Keynes' name lent to the debate: 'The ... authority was [sic] Professor Keynes. Everyone knows that Professor Keynes is an authority whose moderation is well recognised. It is thought sometimes that he is too moderate. ${ }^{42}$

Other political speeches made explicit reference to Keynes' book. For example, Captain Benn intoned:

I have had to rely on such sources of information as are available to the public, but the charge has been made with greater authority than I could make it in Mr. Keynes' book, and I think it desirable to clear

${ }^{40}$ Hansard/House of Commons/10 February 1920.

Herbert Louis Samuel, first Viscount Samuel (1870-1963) had been involved in politics before going up to Oxford. His encounter with extreme poverty deeply affected him and from this early point he determined on a political career in the Liberal Party. Source: Wasserstein, Bernard, (ODNB, 2004, 35928).

${ }^{41}$ Hansard/House of Commons/15 March 1920.

George Henry Roberts (1868-1928) was a trade unionist and politician. He became active in the Independent Labour Party (ILP) in the mid-1890s. He was a member of the party's executive committee and an influential leader in the general Labour political movement in the pre-war years. Source: Tracey, H. T., (ODNB, 2004, 35769).

${ }^{42}$ Hansard/House of Lords/1 November 1921. No doubt some of Keynes' more trenchant critics would have taken issue with these views of Baron Parmoor! 
up, once for all, whether, in the view of the Government, the Peace Treaty actually carries out the pre-Armistice terms. ${ }^{43}$

Esmond Harmsworth, addressing the House of Commons stated:

I would venture at the outset of my statement very humbly and respectfully to warn the House against a certain attitude of mind that has been adopted very largely in regarding the Peace Treaties with our former enemies. This attitude has been expressed with singular literary skill by Mr. Keynes in his well-known book on the Peace Conference in Paris, a book which it is possible to read with great pleasure, although it is not always necessary to agree with $\mathrm{Mr}$. Keynes' views. The attitude I indicate amounts to this: it is the attitude of a man who, surveying the several Peace Treaties so far as they have now been drafted, seems to assume that if any of these Treaties fall short of what he thinks desirable, the fault lies altogether with the high contracting parties who have acted for the Allies. ${ }^{44}$

In a similar vein Sir W. Mitchell-Thomson, this time on the subject of what Germany should be expected to pay by way of reparations, provided the most detailed summary of any sitting Parliamentarian on Economic Consequences:

With regard to the question of payment, Mr. Asquith, as I say, boldly committed himself to two thousand millions as the total expected

${ }^{43}$ Hansard/House of Commons/8 February 1922.

William Wedgewood Benn (1877-1960) was a junior lord of the Treasury when first serving in Parliament from 1910-15. He resigned during the war to take part in active service and later published a book on his wartime experience. At the general election of 1918 he was returned to Parliament as member for Leith. Source: Hale, Leslie, (ODNB, 2004, 30705).

${ }^{44}$ Hansard/House of Commons/14 April 1920.

Esmond Cecil Harmsworth (1898-1978) was heir to the Associated Newspapers Group, his two elder brothers having been killed in the war. In 1919 he accompanied Lloyd George as his aide-de-camp at the Paris Peace Conference. He won a by-election in the same year and at only nineteen was 'the baby of the House.' In 1929 he abandoned Parliament to concentrate on his business interests. Source: Blake, Robert, (ODNB, 2004, 31202). 
from Germany, and I am bound to say I have a strong suspicion that, although the voice was the voice of Paisley, the inspiration really comes from somewhere very close to King's College, Cambridge, and that Mr. Keynes and his book are responsible for rendering vocal this sentiment which hon. and right hon. Gentlemen on the Front Opposition Bench have hitherto successfully subdued. I am bound to say something with regard to Mr. Keynes' book. I should like to say I recognise the sincerity of Mr. Keynes. I was a colleague of his with the Noble Lord for months in the Supreme Economic Council in Paris, but I would like the House to realise this, that the views which are put forward by Mr. Keynes, and which are now accepted as the new revelation by the right hon. Gentlemen and Member for Peebles and by Mr. Asquith, are not new views. They were held by Mr. Keynes months ago, and they were expressed by him months ago, and they were considered, weighed, judged, and rejected in Paris. I confess I am rather sorry that at this moment Mr. Keynes should have produced the book which he has issued. I think it is calculated to render the position of the Allies much more difficult than it was, and to embroil us in petty strife in America, and I think it is a departure, and in my judgment, I am bound to say quite frankly, a regrettable departure from the traditions which have hitherto governed the public service. ${ }^{45}$

Mitchell-Thomson goes on at some length dealing with the substance of the book, preferring his own, usually contrary, views. Perhaps it is not surprising that politicians freely commented on the book. Not only was it a publishing success among the general public, but Keynes had personally sent at least seventy-three copies to members of the Asquith and Lloyd George Governments, former Treasury colleagues, European bankers and financiers Keynes had met in connection with discussions of an international loan scheme in the autumn of 1919 , and to Bloomsbury friends and members of his family. ${ }^{46}$

\footnotetext{
${ }^{45}$ Hansard/House of Commons/12 February 1920. There is no entry for Mitchell-Thomson in the Oxford Dictionary of National Biography.

${ }^{46}$ Moggridge, (1992, p. 335).
} 
If the views and opinions among politicians were divisive, they were no less so among the scholarly community. Hawtrey ${ }^{47}$ was one of the first to comment and wrote to Keynes:

How many things you have said which greatly needed saying! And how well you have said them! I hope you mean to put on record a great deal more of the history of the world since 1914, but you will hardly find it possible to produce another volume as interesting and as vivid as this! $!^{48}$

Another admirer was Gilbert Murray ${ }^{49}$ who wrote to Keynes:

\section{Dear Mr. Keynes}

I dare say your book will bring you many letters and I am reluctant to add to the burden of them. But I must write to tell you of the great admiration and gratitude with which I am reading it. It is not merely admirably done; but it is exactly the thing that needed doing, and I cannot help hoping that it may have a great political effect. I have been denouncing the Peace Treaty ever since it was made at Liberal meetings and elsewhere, and have found no one to defend it with any fervour. But all the time we were at great disadvantage because we could not speak with knowledge and authority. ... It seems to me that

\footnotetext{
${ }^{47}$ Sir Ralph George Hawtrey (1879-1975) was elected to the Apostles at Cambridge and like Keynes came under the lasting influence of Moore's philosophy. He spent his working life as an economic adviser at the Treasury and learnt his monetary economics largely from experience there. Outside office hours he wrote and published more contributions on monetary theory than most of his academic contemporaries. He remained a close friend of Keynes following Cambridge. After Hawtrey's criticisms of some of the ideas in Keynes' Treatise on Money (1930), Keynes acknowledged them to have been 'tremendously useful' in helping him develop his General Theory of Employment, Interest and Money (1936). Source: Black, R. D. Collison, (ODNB, 2004, 31212).

${ }^{48}$ R. G. Hawtrey to J.M. Keynes, 18 December 1919, Elm Park Gardens, S.W. 10., King's College Archives, $\mathrm{JMK} / \mathrm{EC} / 2 / 1 / 56$.

${ }^{49}$ Gilbert Aimé Murray (1866-1957), classical scholar and internationalist.

Source: Stray, Christopher, (ODNB, 2004, 35159).
} 
the whole nation is suffering from a sort of inhibition of the higher faculties, both of thinking and feeling. And it is possible that your book may break it. ${ }^{50}$

Most contemporary scholars acknowledged the importance of Keynes' economic analysis but tended to devote their reviews to the political players whom Keynes held responsible for his pessimistic view of Europe's future, thus putting more emphasis on the politics than the economics. King perhaps expresses it best in his review, 'the book overemphasises the relative power and importance of individuals. ${ }^{51}$ But, having made this observation, King identifies that Economic Consequences

has attracted world-wide attention because of its analysis of Germany's ability to pay ... two decisions made since the book was written bear out the two main theses of the book which are that the indemnities were in excess of Germany's ability to pay and that the indemnities should be expressed in concrete terms. ... the author's economic analysis is significant. ${ }^{52}$

Others who reviewed Economic Consequences during 1920 shared similar views of the significance of both the book's political and economic analysis. For example Taussig, ${ }^{53}$ writing a little under two months after the book's publication, devotes much of his review

\footnotetext{
${ }^{50}$ Gilbert Murray to J.M. Keynes, 17 December 1919, Yatscombe, Boar's Hill, Oxford, King's College Archives, $\mathrm{JMK} / \mathrm{EC} / 2 / 1 / 48$.

${ }^{51}$ King, (1920, p. 173). Clyde Lyndon King (1879-1937) was an American economist/writer who wrote at least 10 books, often around the regulation of municipal utlities and associated economic issues. The two books he seems best known for were The World's Food, (1917), American Academy of Political and Social Science, Philadelphia and The Price of Milk, (c. 1920), University of Toronto, Philadelphia.

52 King, (1920, p. 173).

${ }^{53}$ Frank Taussig (1859-1940) was an American economist who taught at Harvard University, and worked on international trade. His articles and books on tariffs, both in theory and in empirical studies of industry and history, form the foundation for how trade theory is taught today. He was editor of the Quarterly Journal of Economics.

Source: The Online Library of Liberty. http://oll.liberty.org/
} 
to the way in which Keynes discussed the 'dictatorial' attitudes of the 'bourgeois French' and the 'imperialistic Britain.' Taussig believed Keynes went to 'great lengths' to lay the responsibility for the Treaty outcome on President Wilson and argues that 'the high hopes inspired in 1918 are contrasted with the distress and heart sinking of 1919.' Taussig also took issue with Keynes' political observations and argues, '[the] degree of intimacy with the characters of the actors is vouchsafed only to writers of fiction. ${ }^{54}$

Taussig, however, devotes as much space to a discussion of Keynes' economic analysis as he does to his political views. While he finds himself in 'general accord with what Mr. Keynes says,' he does not agree with everything he argues. For example, Taussig 'cannot agree with Mr. Keynes in all his conclusions concerning the weakening of German industries through the loss of territory.' Taussig argues, 'sooner or later I cannot but believe that a modus vivendi will be reached between France and Germany under which each will supply the materials indispensable to the other.' But, Taussig goes on, 'it is true that if the extreme policy of industrial imperialism dominates France, an unstable situation will remain and the economic and political future of all Europe will be gravely imperilled.' In other arguments Taussig finds Keynes promoting 'utopian' solutions. Two of these were Keynes' advocacy of a Free Trade Union for the countries into which central Europe has been split up and his proposals on the question of international loans. ${ }^{55}$

Robertson, ${ }^{56}$ who, for much of the 1920 s worked in close collaboration with Keynes, reviewed the book in March 1920. He acknowledged the importance of Keynes'

\footnotetext{
${ }^{54}$ Taussig, (1920, pp. 381-384).

${ }^{55}$ Taussig, (1920, pp. 384-385).

${ }^{56}$ Sir Dennis Holme Robertson (1890-1963) spent his professional life at Cambridge from 1919, apart from five years (1939-44) at London University and the Treasury. In 1944 he succeeded A. C. Pigou as professor of political economy and held the chair until his retirement in 1957. He was a prolific publisher and made contributions in several areas of economics but chiefly to the relationship between money, the trade cycle, and economic growth. Although Robertson worked closely with Keynes during the 1920s, they began to part ways in the 1930s as Keynes increasingly questioned the views of the classical economists. Robertson ...Footnote continued on next page...
} 
economic analysis but also points out how closely linked this is with the political discussion, to the point where the politics overwhelms the economics:

Mr. Keynes' book is like a banquet of which the more austere and filling courses are both heralded and crowned by a number of more succulent and alluring dishes. His detailed dissection of the economic clauses of the Treaty of Versailles occupies the central tract of the work; but the reader is, as it were, lured into the midst of it, and again rewarded for the patient attention which it demands, by a series of vivid and arresting pictures of men, of institutions and tendencies. Indeed the first impression left on the mind is not merely that Mr. Keynes has written a very powerful and important book, but that he has written two, or possibly three - a mordant political pamphlet, a masterly technical discussion of the economic provisions of the Treaty, and interwoven with both an impressive and largely original philosophical critique of the economic relations of nations and classes. $^{57}$

Robertson does however see through the 'flashier parts' to what he believes Keynes really wanted to make clear: First, the sums which the Treaty proposed to extract from Germany by way of indemnity are excessive and impossible to obtain; second, the impossibility of obtaining them was at least partly due to the cumulative effect of the other clauses of the Treaty; and finally, these other clauses, taken in the mass, are in themselves unwise and suicidal.

Max Handman and Charles Bushnell, in reviews of June 1920 (Handman) and September 1920 (Bushnell), recognised the importance of the dual nature of Keynes'

became an increasingly embittered critic of Keynes' new economics, the main differences centering on the nature of saving, and the relationship between investment, saving, money and the rate of interest.

Source: Fletcher, Gordon, (ODNB, 2004, 35776).

${ }^{57}$ Robertson, (1920, p. 77). 
book. ${ }^{58}$ For example, Bushnell states that 'Keynes' delineations of the characters and circumstances of the chief actors at the Peace Council are picturesque, brilliant, and probably about as accurate as the conclusions of any close observer can be expected to be at the present time. ${ }^{59}$ The remainder of Bushnell's comments are restricted to the economic remedies Keynes proposes. Handman agrees with Keynes that sections of the Treaty are 'immoral' because they 'go contrary to engagements solemnly taken and that they are absurdly extravagant and impossible and dangerously arbitrary.' However, Handman argues, 'Keynes understates the ability of Germany to pay, provided she is allowed to produce and to sell her products.' Only when Germany is not allowed to do so do 'Keynes' calculations assume the shape of irrefutable truths. ${ }^{60}$

For many contemporary lay people it was the rhetorical style of the book, particularly the descriptions of politicians and the politics surrounding the Conference, that captured their attention rather than anything of note in Keynes' economic analysis. For example Johnson argues, 'with its under-current of anger and aura of behind-thescenes revelation, Economic Consequences transformed a demonstration of economic thinking into a sensational publishing success.' It has been highlighted how in the United States it was a political bombshell and Johnson commented, '[the book was] gleefully seized upon by the opponents of the President.' Germany saw a champion in the 'ranks of

\footnotetext{
${ }^{58}$ Max Sylvius Handman (1885-1939) was born in Romania and educated in the US. He taught at the University's of Chicago, Missouri, Texas and Michigan. He was Professor of Sociology and Economics while at Texas University. Source: http://www.utexas.edu/faculty/council/2000-

2001/memorials/AMR/Handman/handman.html

Charles Joseph Bushnell (1875-1950) graduated from Chicago University with a PhD in Sociology in 1901. His thesis was on the social problems of the Chicago stock-yards. From 1901-3 he was Sociology Professor at Albany College and President of Pacific University from 1914-17. From 1918 he was Professor of Sociology at the University of Toledo.

Source: http://www.pacificu.edu/about/inauguration/documents/Presidential_HistoryFIN11.pdf

${ }^{59}$ Bushnell, (1920, p. 239).

${ }^{60}$ Handman, (1920, p. 8).
} 
the enemy,' France the 'perfidy of an ally turned adversary.' On the Continent it was reported that the book was 'being passed from hand to hand. ${ }^{61}$ According to Keynes' friends 'everybody' was reading the book. For example Lytton Strachey wrote to Keynes:

Your book arrived yesterday, and I swallowed it at a gulp. ... I think it is most successful. In the first place, extremely impressive; there is an air of authority about it, which I think nobody could ignore. I was rather afraid at Charleston that it might appear too extreme, but I don't think this is at all the case. The slight softenings in the Clemenceau and Wilson bits seem to me distinct improvements, adding to the effect, rather than otherwise. Then the mass of information is delightful. I had never, for instance, had any definite idea as to what the Provisions of the Peace Treaty really were - it was impossible to gather from the newspapers, and the import of the Treaty itself would have been clearly incomprehensible - so that your exposé, apart from the argument, was most welcome; and of course this is only one of a great number of extraordinarily interesting sets of facts. As to the argument it is certainly most crushing, most terrible. I don't see anyone can stand up against it ... one thing I doubted ... whether, on your own showing, even your proposed terms were not far too harsh. Is it conceivable that the Germany, which you describe should be able to or in fact would pay 50 million a year for 30 years? ${ }^{62}$

Passing reference was the way most people noted the economic content; most were more impressed, as Strachey was, with the overall effect of the book. For example Kenna, ${ }^{63}$ wrote to Keynes:

\footnotetext{
${ }^{61}$ Keynes, (CW, XVII, p. 15).

${ }^{62}$ L. Strachey to J.M. Keynes, 16 December 1919, The Mill House, Tidmarsh, Pangbourne, King's College Archives, JMK/PP/45/316/5/64.

${ }^{63}$ R. Kenna should not be confused with the ex-Chancellor Reginald McKenna. The archives are explicit in carrying the handwritten name of R. Kenna, there being no obvious link to Reginald McKenna, unless McKenna forgot, or was in the habit of leaving the Mc from his name when sending correspondence.
} 
My dear Keynes

I have read and re-read your book. Not until I felt sure of my impressions would I write to you. It is indeed a powerful work. I don't know which of its excellences I should place highest - style, vigour, reasoning, truth, suggestiveness, power of convincing - they are all there in full measure. ${ }^{64}$

Written with strong feeling, 'the book frequently provoked strong feeling' and was the subject of much public debate. As has been illustrated references were made in the Houses of Commons and Lords. Mention was also made in church sermons and the legislatures from a number of countries. Its thesis was 'taken up enthusiastically by internationally minded and pacifist organisations.' ${ }^{65}$ In addition to scores of congratulatory letters from famous people,

Keynes received many from private individuals who wrote in sympathetic response to his message - a Parisian dentist, a Brooklyn lawyer, an engineer in Texas, a distant relative in Ohio, a mother in Frankfurt, a man in Mainz, to name only a few. In two days, he told his mother (11 January), he answered fifty. ${ }^{66}$

This response was an indicator that Keynes had successfully communicated beyond a select group of élites.

The response from many of the leading newspapers and periodicals of the day was no less enthusiastic. For example, The Economist carried a review of the book and opened:

Those who agree with Mr. Keynes that "the most serious of the problems which claimed the attention of the Peace Conference were

\footnotetext{
${ }^{64}$ R. Kenna to J.M. Keynes, 27 December 1919, Munstead House, Goldaming, King's College Archives, $\mathrm{JMK} / \mathrm{EC} / 2 / 1 / 129$.

65 Johnson, (CW, XVII, p. 16).

${ }^{66}$ Johnson, (CW, XVII, p. 16).
} 
not political or territorial, but financial and economic, and that the perils of the future lay not in frontiers and sovereignties, but in food, coal, and transport," will perhaps be a little disappointed that the title of his book is not more descriptive of its contents. .. [but] problems of food, coal, and transport deserve to be considered dispassionately, just because they affect, more perhaps than anything else, the lives and happiness of millions of our fellow-men. To approach them from the point of view of a "cold economist" is not to be blind to their emotional significance; on the contrary, the surest way of defeating the ends of decency and good sense is to involve their discussion, with that of other extraneous issues, racial, political, and moral, and this is what Mr. Keynes has chosen to do.

Nevertheless, the reviewer praises Keynes' economic analysis and argues the economic aspects of the Treaty are 'brilliantly presented, and closely and lucidly argued in great detail, with a mastery over a very wide range of intricate facts, which probably no one else has had the opportunity to acquire.' While The Economist shared the view of many commentators that Keynes' descriptions of politicians and the politics of the Conference will 'prove a source of infinite rage or delight, [the reader should not miss the main thesis of the book, which] is economic, not political or moral. ${ }^{67}$

The Times Literary Supplement (TLS), in its review, chose rather to focus on the political and moral content of the book and argued 'this is not the place to attempt a technical analysis of the very complicated economic problems with which the author deals. ${ }^{68}$ The TLS acknowledged Keynes' 'great literary ability, [with his] clear grasp of

\footnotetext{
${ }^{67}$ Withers, Hartley, (ed.), (December 27, 1919), "The Peace Treaty," The Economist, pp. 1192-1193. Hartley Withers (1867-1950) was the editor of The Economist at this time, having taken the post in 1916 where he remained until 1921. He left The Economist to join the Saturday Review from 1921 to 1928, when he abandoned financial journalism. Source: Porter, Dilwyn, (ODNB, 2004, 36984).

68 The reviewer was James Wycliffe Headlam-Morley (1863-1929), a distinguished historian who had been educated in both Britain and Germany and frequently wrote for The Times Literary Supplement. He participated in the Paris peace conference and his most notable service was to act as interlocutor between the Foreign Office staff and the British prime minister's secretariat. Following the signing of the Peace Treaty ...Footnote continued on next page...
} 
general principles, [which] the "non-technical student" can read with pleasure [on] the questions of coal, exchange, and reparation.' ${ }^{69}$ The TLS saves its 'ultimate criticism' for the 'political side,' in which Headlam-Morley argued Keynes had 'little interest or understanding.' For this reviewer political issues were far more important than economic ones. Only once questions of territory and government were resolved should economics be considered:

After all, it is surely to them (principles of the Treaty) whether it is one to be welcomed or not, that Germany emerges from the war with her unity undestroyed and her territorial integrity unhampered, except in those districts in which cession of territory was clearly enjoined by the principles of the Peace. Mr. Keynes seems to us far too ready to bring charges of insincerity; he speaks with scarcely disguised contempt of the Danzig settlement; surely he might have recognised that here there is to be found for instance, a genuine endeavour to solve the very difficult problem presented by the right of Poland to have full access to the sea, and the principle that populations should not be handed from one country to another contrary to their will. .... We may suggest that when the territorial settlement is reviewed by historians it is not the German Treaty which will be open to the most serious criticism; and it will ultimately be recognised that there is much more to be placed to the credit of the account of the President and of the Prime Minister than readers of Mr. Keynes' book would imagine. ${ }^{70}$

he was appointed to a specially created post of historical adviser to the Foreign Office.

Source: Goldstein, Erik, (ODNB, 2004, 33785).

${ }^{69}$ Headlam-Morley, James Wycliffe, (15 January, 1920), "The Economics of the Peace," The Times Literary Supplement.

${ }^{70}$ Headlam-Morley, James Wycliffe, (15 January, 1920), "The Economics of the Peace," The Times Literary Supplement. 
For Blackwood's Magazine ${ }^{71}$ reviewer Keynes' economics are important but not for any positive reason. Rather, 'when Mr. Keynes drops the role of a man and an observer, and takes up that of an economist, he is less amusing and far more dangerous.' For this reviewer Keynes engaged in 'economic nonsense' whose one passion was 'to save Germany distress or inconvenience.' Where 'reproaches are hurled at the Allies on many a page' Keynes only once had a single reproof for Germany and that is that she actually initiated the war. Whether Germany can or cannot pay the 'just bill that has been presented to her we do not know. ${ }^{72}$

What mattered to Blackwood's was that Germany should be made to pay for the damage they alone had inflicted on the world. Because

Germany has brought the suffering on herself and on the world, and she must still bear the responsibility. That the sins of the fathers are visited on the children of the third and fourth generation is not a piece of rhetoric but rather a stern fact. ${ }^{73}$

For Blackwood's writers, who it would be safe to assume would be supported by a majority of its subscribers, Germany deserved to be demonised. Germany, the 'rough and

${ }^{71}$ Blackwood's Magazine was founded in 1817 and survived as a family run firm (Blackwood \& Sons) until 1980. The magazine enjoyed a strong literary tradition carrying articles from distinguished writers such as Walter Scott, George Eliot, Anthony Trollope and Joseph Conrad. 'Throughout its publishing history, the magazine's readers knew that in every issue they received they would find the same general layout and logo on its cover, and the same mix of Conservative tinged articles, editorials and fiction inside.' (Dr. David Finkelstein, "The Rise and Fall of the House of Blackwood's Magazine."

http://www.qmu.ac.uk/mcs/mcc/Blackwoods/blackhist.html).

This consistency was highlighted in a 1917 retrospective article written to commemorate its 100th anniversary. 'Ever since 1817, when it came into being,' wrote the author, 'it has held aloft the twin banners of sound criticism and Tory politics.' (Whibley, Charles, (April, 1917), "A Retrospect," Blackwood's Magazine, 201, p. 433).

72 Blackwood, William (ed.), (February, 1920), "Musings and Method: Economic Nonsense - The Real Wickedness of the Peace," Blackwood's Magazine, No. MCCLII, Vol. CCVII, pp. 287-300.

${ }^{73}$ Blackwood, William (ed.), (February, 1920), "Musings and Method: Economic Nonsense - The Real Wickedness of the Peace," Blackwood's Magazine, No. MCCLII, Vol. CCVII, pp. 287-300. 
greedy' country needed to be humbled in the way in which the Treaty intended because if Germany was not 'their military expansion would march, as always, with their industrial. ${ }^{74}$

There were many other writers and reviewers who saw in Keynes' book a proGerman bias they interpreted as an analytical weakness, albeit not necessarily in the extremist way viewed by Blackwood's. For example, Steed, editor of The Times, wrote a long review of Economic Consequences on 5 January, 1920 and 'marvelled' at the book's political inexperience and 'special tenderness' for Germany. ${ }^{75}$ The book, argued Steed, was an extremely 'clever' book on the Peace Conference and its economic consequences. Readers 'are prepared for a critical economic treatise,' which, argues Steed, they will not, in some respects, be disappointed by, but in others they

will be surprised, amused, shocked, and not a little mystified. How came it, they may ask, that the man who could write the pages of incisive portraiture, not to say caricature, that fill the chapter on "The Conference," came to hold the position of technical advisor to one of the most technical Departments of State? How, unless his bias had been throughout akin to that of the conscientious objector, could he place the Allies persistently on the same moral level as Germany in regard to the war?

Steed accepted that in many respects Keynes 'makes a strong case' against the terms of the Treaty but 'as a whole, his cry against the Peace seems to us the cry of an academic mind.' Furthermore, while acknowledging Keynes' criticism of the economic clauses of the Treaty has 'real value,' the book itself is a work of political exposition and

is little better than propaganda, calculated, though perhaps not designed, to help the enemy and to increase his conviction that, far from having been guilty of willing and making the war, he was the

\footnotetext{
${ }^{74}$ Blackwood, William (ed.), (February, 1920), "Musings and Method: Economic Nonsense - The Real Wickedness of the Peace," Blackwood's Magazine, No. MCCLII, Vol. CCVII, pp. 287-300.

${ }^{75}$ Johnson, (CW, XVII, p. 17).
} 
victim of a deep-laid and envious conspiracy on the part of the Allies of which the Peace Conference, with its "breach of faith," was but a final stage.

Furthermore while Steed acknowledged the 'many sane ideas' of Keynes' book, he argued it is 'so vitiated by a persistent pro-German bias that its value as a contribution to the study of the economic consequences of the war is seriously impaired. ${ }^{76}$

Despite charges of a pro-German bias, Keynes had many supporters among the general public. For example, Dr. Walter Walsh, delivered his religious address on 18 January, 1920 praising Keynes' "literary" work, 'which pierces the conscience like thorns, or grips the mind like a vice.' It was, he argued, a 'nobly-conceived' and 'nobly-worded' book. While Walsh found it difficult to single out a particular saying for 'pre-eminence,' he felt that the text which best expressed the spirit of Keynes' argument was that 'nations are not authorised, by religion or by natural morals, to visit on the children of their enemies the misdoings of parents or of rulers.' But that, according to Walsh, was just what the Peace Treaty did and 'how it came about forms an early, and, in a sorrowful sense, an entertaining chapter in the story. ${ }^{.77}$

The debates rumbled on throughout the 1920s, played out in all the major newspapers and periodicals. Of these The Times probably best highlights the controversy his book stirred up. Between 11 February 1920 and 11 December 1920 there were 37 references in the pages of The Times regarding views put forward in Economic Consequences. In one example, The Times correspondent argued, Wilson's political opponents in the United States were using Keynes' book to try and have the Treaty scrapped altogether. ${ }^{78}$ It has already been highlighted how Mitchell-Thomson gave the

\footnotetext{
${ }^{76}$ Steed, Wickham (ed.), (5 January, 1920), "A Critic of the Peace," The Times.

${ }^{77}$ Walsh, Dr. Walter, (18 January, 1920), "The Economic Consequences of the Peace;" or "The Doom According to Keynes," The Free Religious Movement, Address No. 142 in Steinway Hall, p. 7.

${ }^{78}$ Steed, Wickham (ed.), (11 February, 1920), "Treaty before the Senate," The Times, p. 17.
} 
House of Commons 'a good hostile review of Mr. Keynes' book on the economics of the Peace Conference. ${ }^{79}$ On the same day, The Times carried, in addition to the review of Mitchell-Thomson's speech, another three separate articles referring to Keynes' book. The first was a report from the American House of Representatives when The Times reported, 'the Republican [Party] "irreconcilables" are disconcerted. They hammered away today at the defects of the Treaty as supposed to have been revealed by Mr. Maynard Keynes and others. ${ }^{, 80}$ In its editorial of the same day, a review of Balfour's address to the House of Commons had The Times opining that it was easy to show that, if Germany thinks the economic terms imposed upon her and her inability to comply with them to be so great as does Mr. Keynes, she has her remedy in the provisions of the Treaty. ${ }^{81}$ Balfour is again quoted: 'I had some doubt as to whether this was to be a debate on Mr. Keynes' attack on the Conference and his apology for Germany, or rather his plea in favour of it. ${ }^{82}$ The following day The Times carried an account of a visit from Paul Mantoux (father of Etienne) who, in an interview with the Foreign Press Association acknowledged that Keynes 'had written a clever book about the Council of Four, but Mr. Keynes had never been present at one of its meetings. ${ }^{83}$ The implication that Keynes somehow exaggerated his account of the Conference attendees, due to his lack of attendance at some key meetings, was subsequently challenged by Keynes as being incorrect while Mantoux's son Etienne went on to write his own book in the early 1940s challenging many of Keynes' figures.

\footnotetext{
${ }^{79}$ Steed, Wickham (ed.), (13 February, 1920), “The State of Europe," The Times, p.12.

${ }^{80}$ Steed, Wickham (ed.), (13 February, 1920), “Mr. Wilson and the Treaty," The Times, p. 13.

${ }^{81}$ Steed Wickham, (ed.), (13 February, 1920), “Mr. Balfour on the Situation,” The Times, p. 13.

82 Steed Wickham, (ed.), (13 February, 1920), “Mr. Balfour's Reply,” The Times, p. 17.

${ }^{83}$ Steed, Wickham, (ed.), (14 February, 1920), “Interpreter's Stories," The Times, p. 16.
} 
However, it was not until a letter from John Foster Dulles, who had been legal advisor to the American financial delegation at Paris, was published in The Times that in Keynes' own estimation, the 'first serious and responsible criticism' of Economic Consequences was made. ${ }^{84}$ Dulles had taken a major part in framing the reparation and financial sections of the Treaty and as a member of the Provisional Reparation Commission had observed their practical application. Dulles advanced the idea in his letter, 'the very evils for which Keynes criticised the Treaty were nullified by safeguards contained in the Treaty itself.' Dulles also sought to correct what he considered were errors of fact made by Keynes. For example, where Keynes blamed the Americans for the inclusion of pensions and separation allowances in the Treaty, Dulles pointed out that this was rather included at General Smuts' prompting. Regarding Keynes' argument for Germany's reparation liability to be fixed at $£ 2,000$ million, Dulles argued that:

Mr. Keynes takes no account of the marked appreciation of values which has occurred ... the nature of the damage wrought was such that enormous sums must be spent in preliminary work (removing debris, etc.) ... [while] I do not consider that the damage amounts to such figures as has been intimated by some interested authorities, nevertheless I believe the amount of material damage substantially exceeds Mr. Keynes' estimate of from two to three thousand million pounds.

From here Dulles moved onto the crux of his argument:

The Treaty in its present form, while it can by no means be regarded as perfect, dealt with an intensely practical problem in what is believed to be a practical and constructive way .... The alleged excessive powers of the Reparation Commission are restricted to powers essential to an intelligent alleviation of terms and modes of

\footnotetext{
${ }^{84}$ Dulles started a diplomatic career in 1907 at the age of 19 . When he was 30 President Wilson named him as legal counsel to Versailles and afterwards he served as a member of the war reparations commission. He later served as secretary of state under President Dwight D. Eisenhower (1953-59). Source: McHendry,
} (1992). 
payment in the event that they prove to be excessive; the whole operation to be akin to that of a settlement in which the creditors recognise that their own interest lies in preserving and enhancing the economic vitality of their debtor.

Dulles concluded his letter by acknowledging, if the Reparation Commission were to exercise its functions in a spirit obviously destructive to the interests of the Allies, then Keynes' condemnation of the Treaty would be explicable. However, if, as Dulles believed it would, the Commission conducted itself with wisdom and 'in accordance with the true interests of the nations it represents,' then the treaty could be regarded as a 'statesmanlike accomplishment. ${ }^{85}$ Keynes replied to Dulles' letter on 19 February. He expressed 'sympathy' and 'respect' for Dulles as a colleague at the Conference and acknowledged his efforts to 'ensure a Peace which should be in accordance with the engagements of his country and of mine.' However, Keynes directly challenged four of Dulles' estimates with estimates of his own, and in an approach similar to that taken in his book, provided detailed explanations for how he had arrived at his own estimates. ${ }^{86}$

What in summary can we say about public opinion as expressed through the organs of The Times and other newspapers and periodicals of the period? Johnson comments that the following verses published in Punch on 14 January 1920 perhaps give a 'fair impression' of the reaction of the educated English middle class opinion Keynes sought to reach: ${ }^{87}$

\section{THE CANDOUR OF KEYNES}

(Suggested by the perusal of 'The Economic Consequences of the Peace')

\footnotetext{
${ }^{85}$ Steed, Wickham, (ed.), (16 February, 1920), The Times, p. 10.

${ }^{86}$ Steed, Wickham, (ed.), (19 February, 1920), “Reparation and Settlement," The Times, p. 10.

${ }^{87}$ Keynes, (1977, p. 17).
} 
There was a superior young person named KEYNES

Who possessed an extensive equipment of brains, And, being elected a Fellow of King's, He taught Economics and similar things.

On the outbreak of war he at once made his mark As a 'temporary', but Principal, Treasury Clerk, And the Permanent Staff and the CHANCELLOR too Pronounced him a flier and well worth his screw.

So he went to the Conference, not as a mute, To act as the CHANCELLOR'S chief substitute, And in this extremely responsible post

He mingled with those who were ruling the roost.

The Big and redoubtable Three, 'tis confessed, By his talent and zeal were immensely impressed; But, conversely, the fact, which is painful, remains That they failed to impress the redoubtable KEYNES.

So, after five months of progressive disgust, He shook from his feet the Parisian dust, Determined to give the chief Delegates beans And let the plain person behind the Peace scenes.

Though his title is stodgy, yet all must admit That his pages are seasoned with plenty of wit; He's alert as a cat-fish; he can't be ignored; And throughout his recital we never are bored.

For he's not a mere slinger of partisan ink, But a thinker who gives us profoundly to think; And his arguments cannot be lightly dismissed With cries of 'Pro-Hun' or of 'Pacifist'.

And yet there are faults to be found all the same; For example, I doubt if it's playing the game For one who is hardly unmuzzled to guy

Representative statesmen who cannot reply. 
And while we're amused by his caustic dispraise

Of President Wilson's Chadbandian ways,

Of the cynical TIGER, laconic and grim,

And our versatile PREMIER, so supple and slim -

Still we feel, as he zealously damns the Allies

For grudging the Germans the means to arise,

That possibly some of the Ultimate Things

May even be hidden from Fellows of King's. ${ }^{88}$

This review damned the book as 'clever' and marvelled at its political inexperience and special tenderness for Germany, but acknowledged that as a constructive criticism of the economic clauses of the Treaty it had real value. Many English and European critics simply accused Keynes of writing pro-German propaganda.

Keynes let most of the adverse criticism pass him by, responding only to what was illogical or a mis-statement of fact, and in general kept silent through a great deal of abuse. When he did answer, however, he could be extremely cutting. For example, on one occasion he sent a brief reply to Sir Herbert Stephen, who had written a long letter to The Times, and accused Keynes of making a 'virulent attack on the honour of our own and the French Governments' and argued that no legal contract had been entered into by the Allies, which bound them to the principles of Wilson's Fourteen Points. Keynes sent a curt reply to The Times dismissing Sir Herbert's arguments with a final sentence: 'It is an extraordinary commentary on the workings of the human mind that Sir Herbert Stephen should believe that he has thus contributed to the establishment of our good faith.' In an earlier draft of the letter, Keynes had written the last sentence: 'The existence of people like Sir Herbert Stephen does, however, render intelligible the present state of the world without resort to the hypothesis of moral turpitude. ${ }^{89}$

\footnotetext{
${ }^{88}$ Keynes, (1977, pp. 16-17).

${ }^{89}$ Keynes, (1977, p. 18).
} 


\subsection{Summary - Economic Consequences of the Peace}

The publication of Economic Consequences at the end of 1919 exceeded the expectations of Keynes' publishers, Macmillan \& Co., Limited, who did not expect it to be a best-seller and were conservative in their proposals to Keynes. This led Keynes to reverse the normal author-publisher relationship: he paid Macmillan ten per cent of the production costs as well as ten per cent on the sale price, and kept the resulting profits. He used this arrangement for everything else he would publish with Macmillan other than How to Pay for the War. ${ }^{90}$ The archives are silent on how Keynes' saw the likely success of his book but Keynes rarely, if ever, suffered from self-doubt, so it is more than likely that he felt vindicated by its publishing success.

But despite the success and the book's impact on contemporary 'outsider' public opinion and 'insider' élite opinion, Keynes expressed frustration that many readers failed to grasp the serious economic intent and message of his book. A number of contemporaries judged the book as nothing more than 'political polemic,' with economics playing a supporting and backstage role. For those who did accept the serious economic import of Keynes' arguments, it was seen as a prescient text that needed to be taken seriously if the failings of the Peace Treaty were to be addressed in time.

This analysis of the success or otherwise of Keynes' communication of his economic ideas highlights how difficult it is to judge communicative success. In Keynes' case there is little doubt that many of Keynes' economic ideas have become well known and understood with many accepted as economic orthodoxy. However, controversy still surrounds much of what he argued, even where his views have a ring of prescience about them. In their correspondence with Keynes, Chamberlain and Dulles had argued that if Keynes had stuck to just his economic arguments he would have been more persuasive.

${ }^{90}$ Source: Cairncross, Alec, (ODNB, 2004, 34310). 
Yet the weight of analysis and opinion tends to suggest that without the 'flashier' parts that characterised Keynes' rhetorical style, Economic Consequences may never have been a publishing success and consequently would have failed to communicate his economic ideas. The question is, then, what forms of communication will best enable an economist to have his or her ideas disseminated in ways that minimise distortion and misunderstanding? A close and critical examination of Economic Consequences will demonstrate that the answer is a mix of scientific exactitude, rhetorical style and intellectual public performance. 


\section{Chapter 3 Intellectuals and the Communication of Economic Ideas}

There are three sub-sections in this chapter. First, the definition and role of a public intellectual is discussed. Second, the place of cultural influences and intellectuals is examined. Finally, is an inquiry into the process of communicating and disseminating ideas.

Keynes, by the conventional standards of his day, was well educated at the time of writing Economic Consequences. He was a graduate of Eton and Cambridge University and a fellow of King's College. He was actively teaching at the time he wrote Economic Consequences and his association with King's continued for the rest of his life. During the war years he worked for the British Treasury and served as part of the official delegation at the Versailles Conference. During his time with the Treasury he was considered their expert on Reparations. He became editor of the Economic Journal in 1911, a position he held until near the end of his life. He also became a part-time journalist for the Manchester Guardian shortly after completing Economic Consequences, a role that enabled him to promote his ideas to a wide audience. During the first half of the 1920s he was better known in some circles for his public activities than for his scholarly works. In this regard his activities as a public intellectual are important to our understanding of how ideas are communicated.

In this chapter an examination is undertaken of what constitutes a public intellectual. The contention of this dissertation is that a successful public intellectual is a person who meets the criteria outlined by Collini in Absent Minds. ${ }^{1}$ First, Keynes' intellectual achievements were recognised by colleagues, politicians, businessmen, policy makers and the general public. Second, Keynes regularly and effectively utilised a variety

${ }^{1}$ Collini, (2006). 
of communication channels. Third, Keynes addressed general and practical concerns of the public. Fourth, he enjoyed a reputation for engaging the public by saying important and interesting things directly addressing public concerns. Finally, his success as a public intellectual was enhanced through the activities of followers and disciples who shared his interest in communicating his ideas.

The importance of cultural influences in the communication process is examined next. Keynes was explicit and often successful in his attempts at communicating ideas in a persuasive manner. Many of his ideas were shaped by his environment and he in turn helped shape his cultural surroundings. Much of this can be explained by an examination of a number of influences, especially when he was a younger man. His early education at Eton provided him with an anti-Benthamite sentiment towards capitalism, which never left him. His education at Cambridge and his membership of the Cambridge Apostles were life-long influences for two reasons. First, Keynes came under the sway of Alfred Marshall, his teacher and mentor in economics. Marshall was the first intellectual to seriously work for the professionalisation of economics, free from political economy and commerce in general in order for economics to be recognised as a legitimate social science. The attention to scientific exactitude and the professionalisation this involved came to define Keynes' career. The second way in which his time at Cambridge is significant were the influences of G.E. Moore's views and his lifelong friendship with Lytton Strachey. From Moore, Keynes learned to put friendship and community before all else. From Strachey, he drew literary inspiration enabling him to develop his own unique and successful style of communication. Another critical influence was his involvement with the Bloomsbury set. This circle of friends did not operate any form of membership but it did provide a rich intellectual environment from which Keynes drew inspiration.

The third and final sub-section of Chapter Three is an examination of the process of communicating ideas. Without an understanding of this, it is difficult to judge what we mean by successful communication. There are a number of components to this discussion. First, there is the process of information dissemination. Robert Solow's view that 'ideas turn to mush' is of particular interest as many readers of Economic Consequences did not Page 54 
grasp the seriousness of the books economic arguments. There were, of course, a number of reasons for this, which are examined. One of the more important was the dissemination difficulties of an intellectual communicating with a non-specialist audience. The second part of the examination of the communication process is the rhetoric used by economists. The meaning of rhetoric has changed in the last 100 years from when Keynes' generation of intellectuals were educated in the classics, and the rules of rhetoric were taken seriously. A rhetorician in this period was taught to write and present with the explicit purpose of persuading an audience, something Keynes proved to be particularly skilled at. The final component of an examination of the process of communicating economic ideas is a discussion of how economics has been treated as a literary subject. This is important because Keynes' primary communication medium was literary. This examination also shows the importance of the nineteenth century for the development of economics and literature, a tradition that influenced Keynes and served as a platform for him to build on, with new and innovative ways of communicating economic ideas. The chapter closes with a discussion of the tradition established by other economists who were successful public intellectuals. My selection includes Smith, Ricardo, Mill, Marx, and Marshall. All were successful public intellectuals and eminent economists who saw their ideas spread to a wider audience of non-economists. 


\subsection{The Public Sphere and the role of the Intellectual}

\subsubsection{The Public Sphere}

The notion that ideas spread through the activities of individuals who act as intellectuals in the public sphere is a powerful one. The implication is that we might in some way better understand the process of disseminating ideas by studying the views of people who devote themselves to the activity of thinking about public concerns. The label often used to describe these individuals is public intellectuals, which assumes we know what is meant by the term "public." But, our assumptions need closer scrutiny when questions are asked: what is "the public" and what kind of powers does it have in a representative democracy? Or: how does "public opinion" shape political power or policy? This test forms the central concern of Habermas. Habermas in The Structural Transformation of the Public Sphere (1962) explores the status of public opinion in the practice of representative government in Western Europe. In this and subsequent works Habermas argues that

by "the public sphere" we mean first of all a realm of our social life in which something approaching public opinion can be formed. Access is guaranteed to all citizens. A portion of the public sphere comes into being in every conversation in which private individuals assemble to form a public body. ${ }^{2}$ They then behave neither like business or professional people transacting private affairs, nor like members of a constitutional order subject to the legal constraints of a state bureaucracy. Citizens behave as a public body when they confer in an unrestricted fashion - that is, with the guarantee of freedom of assembly and association and the freedom to express and publish their opinions - about matters of general interest. In a large public body this kind of communication requires specific means for

\footnotetext{
2 Habermas' concept of the public sphere is not to be equated with that of "the public," ie of the individuals who assemble. Peter Hohendahl (in notes attached to the article by Habermas) argues that Harbermas' concept is directed instead at the institution, which to be sure only assumes concrete form through the participation of people. It cannot, however, be characterised simply as a crowd.
} 
transmitting information and influencing those who receive it. Today newspapers and magazines, radio and television are the media of the public sphere. ... The public sphere as a sphere mediates between society and state, in which the public organises itself as the bearer of public opinion, accords with the principle of the public sphere - that principle of public information which once had to be fought for against the arcane policies of monarchies and which since that time has made possible the democratic control of state activities. ${ }^{3}$

According to Habermas a public sphere only began to emerge in the eighteenth century through the growth of coffee houses, literary and other societies, voluntary associations, and the growth of the press. The successful operation of the public sphere depends on a number of factors. First, the extent of access to the public sphere should be as close to universal as possible. Second is the degree of autonomy within the public sphere. That is to say, citizens must be free of coercion. Third, there is a rejection of hierarchy so that each individual might participate on an equal footing. Fourth is the rule of law, necessary for a public sphere to exist. In particular the state must be subordinate to the law. A fifth and final factor is the quality of participation that involves a common commitment to the ways of logic. For Habermas the success of the public sphere was founded on rationalcritical discourse since everyone is an equal participant and the supreme communication skill is the power of argument. Furthermore he believes the public sphere can be most effectively constituted and maintained through dialogue, acts of speech, debate and discussion. Habermas claims public debate can be animated by "opinion forming organisations." These could be voluntary organisations, social organisations, churches, sports clubs, groups of concerned citizens, grassroots movements, and trade unions, usually expressing opinions that counter or refashion the messages of authority.

Habermas is not convinced, however, that the public sphere has ever been fully realised. As ethnic, gender, and class exclusions were removed through the nineteenth

\footnotetext{
${ }^{3}$ Habermas, Lennox and Lennox, (1974, pp. 49-50).
} 
and twentieth centuries, and the public sphere approached its ideal more closely, Habermas identifies a concurrent deformation of the public sphere through the advance of social welfare, the growth of cultural industries, and the evolution of large private interests. All three examples in some way involve large vested interests and powerful interest groups, subverting an individual's ability to communicate his or her personal opinions. Soules argues that 'large newspapers devoted to profit, for example, turned the press into an agent of manipulation. It became the gate through which privileged private interests invaded the public sphere. ${ }^{4}$ Others agree with Habermas' concerns, for example Jacques Ellul, Herbert Marcuse and Paul Rutherford, ${ }^{5}$ but Harbermas himself acknowledges it is these very institutions that are important for the formation of public opinion. The main concern for Habermas is to ensure 'undistorted communication' as this is a critical tool for human emancipation. The ideal speech for Habermas has four validity claims - comprehensibility, truth, appropriateness and sincerity, and he argues these have a social context in which they have to be justified.

Habermas' arguments mean the intellectual is an important conduit for the communication and dissemination of ideas in the public sphere. For example, while Habermas expresses misgivings about the public sphere being compromised with "distorted communication," due in part to the growth of powerful media outlets whose ownership is in the hands of privileged private interests, an important role for an intellectual is to counter these forces by upholding the ideals of the public sphere. For Keynes this required a process for shaping public opinion, which he expounds in A Revision of the Treaty. ${ }^{6}$ Written as a follow-up to Economic Consequences it gives a clear statement of Keynes' views of the role of public opinion in politics. ${ }^{7}$ Keynes believed reform and

\footnotetext{
${ }^{4}$ Soules, (2007, pp. 1-2).

${ }^{5}$ Soules, (2007, pp. 1-2).

${ }^{6}$ Keynes, (1922).

${ }^{7}$ Moggridge, (1992, p. 370).
} 
change were the products of discussion through which public opinion was formed and guided. The political élite of senior politicians, civil servants and 'higher' journalists were open to two influences, rational persuasion and public opinion. The élite are privy to their own 'inner opinion' expressed 'upstairs, backstairs and behind-stairs' as to what was feasible and desirable. ${ }^{8}$ In public speeches, newspaper articles and other forms of comment, however, the political leadership and 'higher' journalists were directly involved in the public sphere, what Keynes termed 'outer' or public opinion. Although in a democracy the élite was ultimately subject to public opinion, through its own links with that opinion it could significantly shape it. To Keynes, one of the duties of the élite was to prevent too wide a gap appearing between inner and outer opinion on any issue. If the gap became too wide, as it had become, in Keynes' opinion, over the treatment of Germany in 1918-19, the process of returning to sensible or feasible proposals could be lengthy and costly. What was needed was 'a concentrated assault on inside opinion [as a] necessary prelude to converting outside opinion. ${ }^{9}$ This is best illustrated by the first words in his preface to The General Theory: 'This book is addressed to my fellow economists. I hope that it will be intelligible to others. ${ }^{10}$

One complication Keynes saw was that 'outside' public opinion is never as dogmatic or definite as it appears in the press. For the wider public there is always an element of doubt, which leaves views vulnerable to changing events and open to persuasion, a view Keynes had dealt with in A Treatise on Probability. ${ }^{11}$ A further complication for Keynes in the process of shaping both 'inside' and 'outside' opinion was how long it seemed to take to persuade and mould opinions. Keynes' objective after all

\footnotetext{
${ }^{8}$ Keynes, (1992). Chapter 1 outlines these views.

${ }^{9}$ Clarke, (2009, p. 77).

${ }^{10}$ Keynes, (CW VII, xxi).

${ }^{11}$ Keynes, (CW VIII).
} 
was to see public opinion eventually aligned with his own views because only then did he believe the élites (insiders) would be swayed and take action. The time it took, however, did not greatly trouble him. In 1934 he was asked why he had so far been largely unsuccessful in aligning public opinion with his own views, to which he replied: 'Because I have not yet succeeded in convincing either the expert or the ordinary man that I am right. [But] it is, I feel certain, only a matter of time before I convince both; and when both are convinced, economic policy will, with the usual time lag, follow suit. ${ }^{12}$ The reason the time lag did not bother him was that, as important as persuasion was, it was equally important to ensure his ideas were 'scientifically' correct if they were to be rhetorically persuasive. Clarke argues, '[no matter how] attached he was to the method of rational persuasion, he had few illusions about the bloodless triumph of ideas as such. ${ }^{13}$

Keynes, then, saw persuasion as encouraging the formation of 'outside' opinion as well as altering the views of the élite. His own activities were directed at this development and alignment of 'inside' and 'outside' opinion. This usually meant old habits of thought or prejudices were, as a result, removed or undermined and the ground prepared among the public at large, 'so that the élite, once persuaded, could successfully lead rather than follow. ${ }^{14}$ In such a process, meetings with officials, ministers and MPs, public speeches, articles in the quality and popular press all played their part. In the early 1920s, Keynes was only beginning to learn how to use them to maximum advantage. He had been unsuccessful in changing opinions over the Peace Treaty but 'by the outbreak of the Second World War, he would be much more skilled - and perhaps more immediately successful. ${ }^{15}$

\footnotetext{
${ }^{12}$ Keynes, (CW XXVIII, p. 35).

${ }^{13}$ Clarke, (2009, p. 77).

${ }^{14}$ Moggridge, (1992, p. 370).

${ }^{15}$ Moggridge, (1992, p. 370).
} 


\subsubsection{Towards a Definition of the Public Role of the Intellectual}

The activities of an intellectual performing a public role require a definition, although there is a wide divergence of views on what defines a public intellectual. The term is so troublesome for some they prefer to drop the label 'public' altogether and rather focus on the activities of intellectuals, operating in the public sphere. Stefan Collini is among this group and he provides a definition broad in scope. ${ }^{16} \mathrm{He}$ argues, an intellectual playing a public role is any leading cultural figure who is a creator of ideas and shaper of public opinion, avoiding a definition that rests on measurement or formula. He also avoids a market-based approach, which means he does not accept an intellectual can claim the label public intellectual if he or she works in the public sphere for reasons of monetary reward. Collini does, however, recognise that intellectuals, like everyone else, must make a living. However, he rejects Russell Jacoby's argument that being an intellectual from the middle-to-end of the twentieth century to present day has meant an intellectual means 'almost exclusively [being a] professor.' ${ }^{17}$ Jacoby argues, when combined with the destruction of the independent intellectual's urban environment, intellectuals have been transformed from critics and bohemians into academics governed by the realities of bureaucratisation and tenured employment, and the result has been conformity and mediocrity.

What this difference in views highlights is that scholars have different ways of approaching a definition. For example, Posner defines a public intellectual as someone who expresses themselves in ways accessible to the public, with the focus of their

\footnotetext{
${ }^{16}$ Stefan Collini is Professor of Intellectual History and English Literature at the University of Cambridge and a Fellow of Clare Hall. A leading intellectual historian and cultural commentator, he is a frequent contributor to the Times Literary Supplement, The London Review of Books, and other periodicals both in Britain and the US. He is a Fellow of the British Academy and of the Royal Historical Society. Sourch: Collini, (2006).

${ }^{17}$ Jacoby, (2000 (a), p. 6). Russell Jacoby is the author of seven books, including The Last Intellectuals (Basic), Dogmatic Wisdom (Doubleday) and most recently The End of Utopia (Basic). He is currently Professor-inResidence in the Department of History at University of California, Los Angeles. Source: Jacoby, (2000 (b)).
} 
activities being on matters of general public concern, usually of a political or ideological nature. ${ }^{18}$ The public Posner is interested in is the 'educated general public' although an 'intellectual who cannot communicate with more than a coterie of specialist readers is not a public intellectual however interdisciplinary and politically significant his writings may be. ${ }^{\prime 19}$ Furthermore, for a specialist to be classified as a public intellectual means they cannot merely write for the general public in ways that explain their specialty. For example, scientists such as Paul Ehrlich, Stephen Jay Gould, Richard Lewontin, and Edward Wilson, who write for a general audience about the ethical and political dimensions of science, are public intellectuals, while a scientist who writes to explain science cannot make the same claim. Finally, Posner argues, a public intellectual is someone who undertakes this task because there is a market for his or her views. Individuals who do not espouse their views for a general audience but are nonetheless analysed in public do not fit Posner's definition of a public intellectual.

For Collini, Posner's demand and supply argument is not helpful. Rather, Collini, designates a public intellectual as someone who performs a role. As such it does not refer to an occupational category or a defining feature in terms of inclinations and capacities.

Terms such as 'teacher' and 'writer' are not useful. Nor are psychological characterisations, such as 'introvert/extrovert' or 'verbaliser,' or evaluative characterisations such as 'great mind' or 'genius.' Rather, Collini argues, a public

\footnotetext{
${ }^{18}$ Posner, (2003, p. 35). Richard Posner was appointed as a judge in 1981 to the US Court of Appeals, where he currently presides. He was chief judge of the court from 1993 to 2000 . He has written a number of books including, Economic Analysis of Law (7th ed., 2007), The Economics of Justice (1981), The Problems of Jurisprudence (1990) and A Failure of Capitalism: The Crisis of '08 and the Descent into Depression (2009). He has taught administrative law, antitrust, economic analysis of law, history of legal thought, conflict of laws, regulated industries, law and literature, the legislative process, family law, primitive law, torts, civil procedure, evidence, health law and economics, law and science, and jurisprudence. He was the founding editor of the Journal of Legal Studies and the American Law and Economics Review. Source: University of Chicago Law School, http://www.law.uchicago.edu/faculty/posner-r.

${ }^{19}$ Posner, (2003, p. 26).
} 
intellectual performs a role involving the intersection of four elements he calls a 'grid of co-ordinates.' First, the public intellectual attains a level of achievement in an activity that is esteemed for the non-instrumental, creative, analytical, or scholarly capacities it involves. Second, there needs to be an on-going availability of media or channels of expression that can reach the public unimpaired. Third, the role of the public intellectual involves an expression of views on themes, or topics, which successfully articulate or engage with some of the general concerns of the public. Fourth, to satisfy Collini's definition, the intellectual must have established a reputation for having important and interesting things to say on the general concerns of the public and have the willingness and capacities to say them effectively through the appropriate media. ${ }^{20}$ Individuals who perform as public intellectuals work within this grid of co-ordinates at different levels, sometimes only temporarily, if and when they have something to say that is of interest and addresses public concerns. They play the role of public intellectual permanently if they habitually and constantly enter into this role. Finally, "how "general" the message may be, will always be matters for judgment in particular cases, [especially where] questions [are] not resolvable by measurement or formula. ${ }^{21}$ While Collini only describes this grid we could view it diagrammatically:

\footnotetext{
${ }^{20}$ Collini, (2006, p. 52).

${ }^{21}$ Collini, (2006, p. 53).
} 


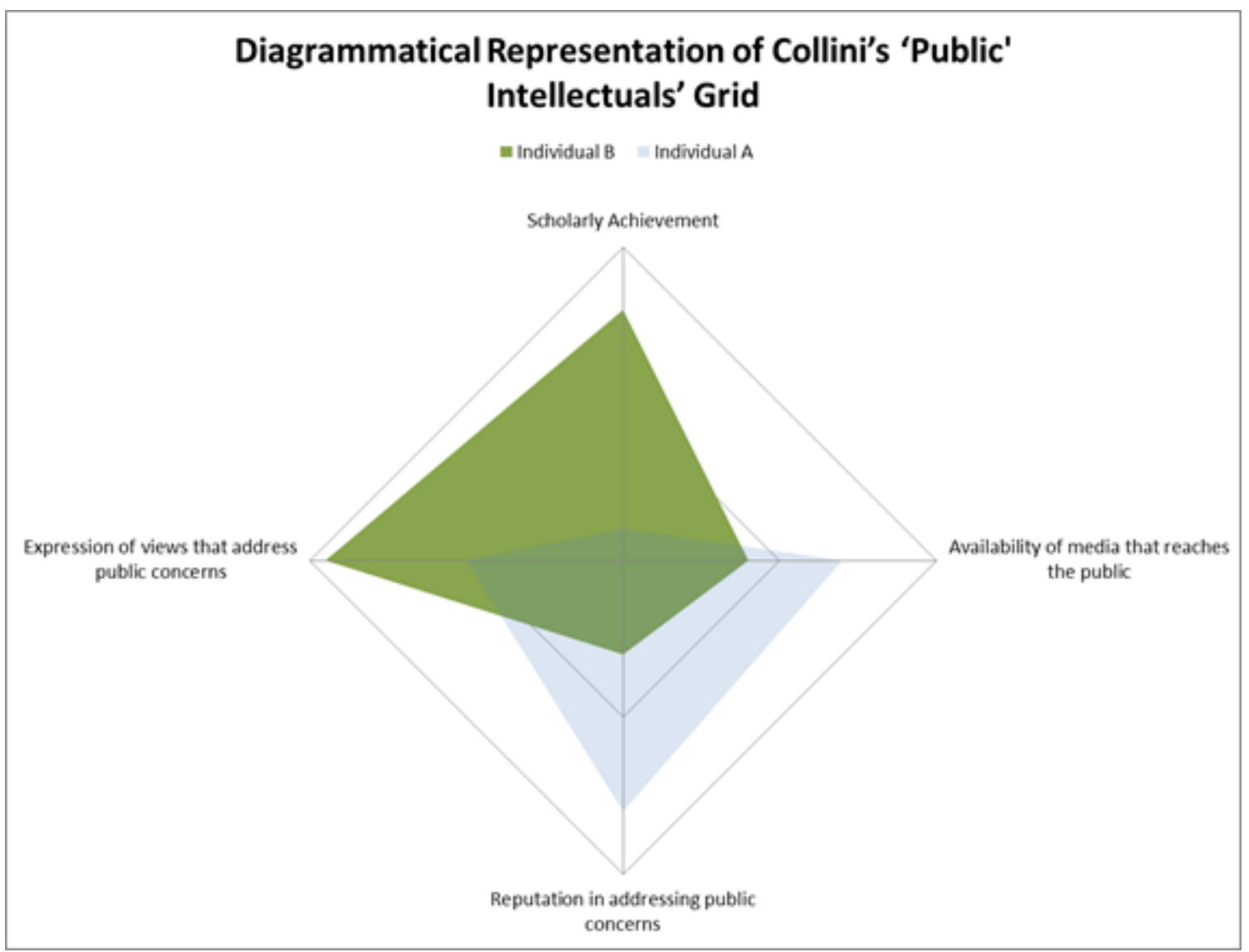

Figure 1 : Diagrammatical Representation of Collini's Public Intellectuals' Grid

In this representation the further the intellectual is from the centre signifies a greater degree of qualification in each attribute. In this example intellectual $B$ has greater credentials/qualifications than intellectual A. However intellectual A has a greater reach in terms of media outlets than intellectual B. Intellectual B on the other hand expounds views that express public concerns to a greater degree than intellectual $A$, although Intellectual A has a better reputation for addressing the issues than intellectual $B$. This diagram is designed to illustrate the holistic nature of the role of a public intellectual and is not meant to imply the role of an intellectual can be reduced to measurement or formula. 


\subsubsection{J. M. Keynes - Public Intellectual}

By almost all definitions Keynes was a public intellectual. Trevelyan, a contemporary of Keynes, believed Keynes engaged with the world in a serious and responsible way and exhibited 'immense disinterestedness and public spirit' and was something of an exception to other intellectuals whom he generally dismissed as "a decadent class." 22 Another contemporary of Keynes, Mackintosh, thought much could be attributed to Keynes' passionate belief in and concern for England. This was in contrast to many of his friends who belonged to what Mackintosh labels 'the rootless intellectuals of the nineteen-twenties and thirties. ${ }^{23}$ From the Economic Consequences to his last article in the Economic Journal, whether he was concerned with the 'dismemberment of Europe, the flexibility of the exchange rates, the relation between investment and income, or buffer stocks of food and raw materials, the pattern of his concern was what was best for England. ${ }^{24}$ While there is no doubt Keynes demonstrated this commitment it would be a mistake to say his passion was restricted to England. While much of Keynes' attention during the 1920s was directed at domestic English concerns, Economic Consequences had shown a concern for European problems, not just English ones. Nonetheless, his passionate calls for economic reform demonstrate how seriously he took public concerns.

\footnotetext{
${ }^{22}$ Cannadine, (1992, p. 39) from Collini, (2006, p. 125). George Maccaulay Trevelyan (1876-1962) was an English historian who became Regius Professor of modern history at Cambridge in 1927 and master of Trinity College in 1940. He was a fellow Apostle with Strachey and Keynes but disapproved of the homosexual influence both men had brought to the group. Source: McHendry, (1992) and Collini, (2006, pp. 124-126).

${ }^{23}$ Mackintosh, (1947, p. 380). William Archibald Mackintosh (1895-1970) was a professor of economics at Queen's University, Canada from 1922 to 1939. During WWII, he was an assistant to the Deputy Minister of Finance in Ottawa and later in the Depratment of Reconstruction and Supply. After the war he was the Dean of Arts and Sciences at Queen's until becoming Principal in 1951. He was a Director of the Bank of Canada and a member of its Executive Committee. Source: Queen's University www.queensu.ca/secretariat/cataraqui/mackintosh.html.

${ }^{24}$ Mackintosh, (1947, p. 380).
} 
His writings also addressed immediate practical problems. In Economic Consequences he argued that immediately following World War One politicians had concentrated so myopically on political solutions they failed to see the only way to build a lasting peace in Europe was to usher in a new economic model. Keynes argued the old days of laissez-faire were over, with some form of managed economy necessary for weathering the difficult days ahead and despite the controversy surrounding it, the influence of Economic Consequences was profound, ultimately changing 'inside' and 'outside' opinion.

For example, Keynes was among the first to alert the world to the dangers of interAllied war debts and German reparations, arguing they were a recipe for economic as well as political disaster. Wilson argues 'we can now see these factors to be the giant step in the descent to totalitarianism and world war. ${ }^{25}$ Keynes was also the first economist to break the news to a world very unwilling to hear it, 'that unemployment was unavoidable in the current economic situation. ${ }^{26}$ In these, as in other matters, Keynes attempted to persuade and influence opinion and public policy, which he did mainly through his writings and were, 'in effect "essays in persuasion." To intellectuals, Keynes was compellingly persuasive both as a writer and a speaker. He wrote with great economy, charm and vigour. $^{27}$

When Collini's definition is applied to Keynes there is a clear match to Collini's grid of role co-ordinates. First, Keynes' intellectual achievements were recognised and highly regarded by colleagues, politicians, businessmen, policy makers, and the general public. Second, Keynes effectively utilised many channels of communication open to him. This ranged from a steady stream of scholarly output, engagement as a journalist for the

\footnotetext{
${ }^{25}$ Wilson, (2005, p. 287).

${ }^{26}$ Wilson, (2005, p. 287).

${ }^{27}$ Mackintosh, (1947, p. 380).
} 
leading papers of the day, and participation in a wide range of public debates. He also used radio broadcasts and the emerging medium of the cinema. In one instance he sought to reassure a nervous public that the financial crisis resulting from the suspension of the gold standard, would not lead to a collapse of the financial system:

Suddenly Maynard appeared on the screen enormously big, in a wellappointed library, blinking at lights and speaking rather nervously, and told the world everything was now going to be all right, England had been rescued by fate from an almost hopeless situation, the pound would not collapse, prices would not rise very much, trade would recover, no one need fear anything. ${ }^{28}$

The third close match to Collini's grid of co-ordinates is the ways in which Keynes addressed practical problems concerning the public. For example, price instability plagued post-war Europe, inflationary and deflationary policies threatened standards of living, and the scourge of unemployment, were all economic issues directly affecting members of the public. Keynes addressed these issues frequently and directly to the public. Finally, he enjoyed a reputation for engaging the public by saying important and interesting things, directly addressing their concerns.

\footnotetext{
${ }^{28}$ Moggridge, (1992, p. 528). 10 ${ }^{\text {th }}$ October 1931.
} 


\subsection{Economics and Culture}

Collini's phrase "cultural authority" implies a public intellectual belongs in a cultural environment both as an influencer and as one who is influenced by his or her environment. ${ }^{29}$ However, the importance of a relationship between culture and economics does not enjoy widespread acceptance. Economists who think the link important often find themselves defending the notion that economics can be understood in cultural terms. Eagleton argues, the term culture is in crisis because we have no accepted notion of what it embraces. For some the term is all encompassing and of necessity economics is part of a culture. Others, however, take a narrower view and divorce reason, and by implication economics, from a definition of culture. ${ }^{30}$

However, Jones' view that economists do not give the subject of culture much thought is difficult to accept given the prominent role scholars of information dissemination give to it. Mokyr, ${ }^{31}$ Crémer, $^{32}$ North, ${ }^{33}$ Barnard, ${ }^{34}$ and Casson ${ }^{35}$ represent a handful of those who give a pre-eminent place to the role of culture in explaining how ideas are communicated. Bigelow ${ }^{36}$ and Klaver $^{37}$ argue culture is central to our understanding of economics and is an influence that is pervasive and without separation

${ }^{29}$ Collini, (2006, p. 452).

${ }^{30}$ Eagleton, (2000 (a))

${ }^{31}$ Mokyr, (2002).

${ }^{32}$ Crémer, (1993).

${ }^{33}$ North, (1990).

${ }^{34}$ Barnard, (1958).

${ }^{35}$ Casson, (1997).

${ }^{36}$ Bigelow, (2003).

${ }^{37}$ Klaver, (2003). 
from the subject of economics. When examining the works and economics of Keynes, in addition to his role as a public intellectual, cultural influences are particularly important in providing explanations for many of his views and activities.

\subsubsection{Keynes and his Cultural Environment}

Prior to Holroyd's first two-part biography Lytton Strachey, published in 1976, few paid much attention to Keynes' cultural environment. Holroyd discussed in some detail Keynes' education at Eton and his friendships in the Cambridge Apostles and Bloomsbury, and since then a number of researchers have increasingly argued the importance of these earlier influences on his economic ideas. Biographies by Skidelskey (1983, 1992 and 2001) and Moggridge (1992) both explained a number of Keynes' economic ideas and activities in the context of cultural environmental influences. Other works by Mini (1991) and Taddeo (2002) deal with cultural influences in considerable detail.

It has been highlighted, one of the most important influences was Moore's views, something Keynes himself acknowledged in Two Memoirs. ${ }^{38}$ Mini argues Keynes appropriated Moore's method for his own critical purposes, which led Keynes to take apart the basic components of the classical system of economics to which most of his contemporaries subscribed. Far from being impressed, Mini argues Keynes found the structure of the classical system illogical, self-contradictory, and superficial. One example is the classical relationship between savings and investment. Known as 'Say's Law' the classical economists regarded as practically synonymous the notion that to save was to invest. In part, this view of the classicists comes from the writings of David Ricardo and John Stuart Mill who rigidly defined the terms of supply and demand in a way that supported the definition of Say's Law as simply 'supply creates its own demand. ${ }^{39}$ However, Ricardo and Mills were just two economists during the nineteenth century who

\footnotetext{
${ }^{38}$ Keynes, (1949, p. 81).

${ }^{39}$ Sowell, (2008, p. 1).
} 
were part of a process of evolution when the basic terms of economics were being debated and continually redefined. While their position may now be judged as simplistic, Say's Law is a good example of a term that has a long history of controversy, which 'sheds light on the enormous difficulties involved when even intelligent thinkers with honesty and goodwill try to understand each other's theories without clearly defined terms and without a clear sense of the conceptual framework of the opposing views. ${ }^{40}$

Keynes' contribution to the debate was to take apart the simplistic conclusion of the classicists and to uncover a world of neglected mechanisms. First, he found an increase in savings reduces consumption. From this line of thought Keynes discovered that a fall in consumption reduces incomes, which has a negative effect on the business outlook, on sales prospects, and hence on the marginal efficiency of capital. Thus, if anything, an increase in savings means a decrease in investment. What to classicists seemed a straightforward flowing of non-consumption (savings) into business consumption (investment), is shown by Keynes to hide a world of complex linkages that must be analysed and, 'not taken for granted. ${ }^{41}$

Taking McClelland's argument, it is the relationship between groups, rather than the groups themselves we should be concerned about, and with Moore, it is the method rather than the outcome that should be the focus of inquiry. Then we have a way of addressing what C. P. Snow saw as the dangers of specialisation. Snow argued that specialisation often pursued by intellectuals has, in his words, come to define "two cultures" of the scientific and non-scientific world of literature and arts. Snow maintained that 'it is dangerous to have two cultures which can't or don't communicate. In a time

\footnotetext{
${ }^{40}$ Sowell, (2008, p. 3).

${ }^{41}$ Mini, (1991, p. 71).
} 
when science is determining much of our destiny, that is, whether we live or die, it is dangerous in the most practical terms. ${ }^{42}$

When Snow's "two cultures" terminology is applied to Keynes we find that as an economist (social scientist) and his association with the Cambridge Apostles and Bloomsbury (arts), Keynes spanned the "two cultures" in ways many other intellectuals have not done. Alexander argues, Keynes was 'perhaps the most influential reforming public intellectual of the twentieth century '[who] sought civil repair through democratic rather than revolutionary means.' Furthermore, Keynes' performance combined

brilliant truth telling with commitment to solidarity and repair, and the high dudgeon of moral denunciation with ethereal participation in an ideal aesthetic world far removed from everyday modern life. Keynes condemned capitalists for their demonic and irrational "animal spirits," but he fervently believed in the singular power of capitalist economies to provide the material means that were necessary, in his view, to facilitate the good life. ${ }^{43}$

Marr also believes Keynes played a unique public role and endorses Peter Hennessy's claim that he represented 'the real purpose of intellectuals in a society, which is to hold up evidence and truth to those in power, to provide the inconvenient analysis to those who want the swift and meretricious solutions. ${ }^{44}$ Once full material prosperity is achieved for all, Keynes thought 'all the unjust aspects of wealth distribution that serve only to inflate egos can be dispensed with,' sounding, argues Nelson, remarkably like Marx but without the necessity of violent revolution as the prelude to a new world of peace and harmony. In time Keynes came to distrust politicians and 'sought to influence public opinion directly,

\footnotetext{
${ }^{42}$ Snow, (1998, p. 68).

${ }^{43}$ Alexander, ( 2005, p. 10).

${ }^{44}$ Marr, (1996, p. 12) from Collini, (2006, p. 38).
} 
which he regularly did with great success. ${ }^{45}$ Keynes' ability to span the "two cultures" also helped establish his cultural authority, a process that had begun from when he was a young man.

Mini argues, we can only understand Keynes' economics by understanding the early influences of his youth, first from his education at Eton and its anti-Benthamite sentiment. Those in Keynes' circle rejected the harsh utilitarian views of Bentham, Keynes stating in his memoir that 'we were amongst the first of our generation, perhaps alone amongst our generation, to escape the Benthamite tradition. ${ }^{46}$ Keynes and his circle of friends turned rather to Coleridge's, and others', humanistic views. The second important influence were his activities with the Cambridge Apostles and the influence of Moore's philosophy. Keynes described that:

I went up to Cambridge at Michaelmas in 1902, and Moore's Principia Ethica came out at the end of my first year. I have never heard of the present generation having read it. But, of course, its effect on us, and the talk which preceded and followed it, dominated, and perhaps still dominates, everything else ... For us, those who were active in 1903 ... the influence was not only overwhelming ... it was exciting, exhilarating, the beginning of a renaissance, the opening of a new heaven on a new earth, we were the forerunners of a new dispensation, we were not afraid of anything. ${ }^{47}$

Keynes and his fellow Apostles took Moore's ethics as the philosophical basis for their deep friendship and community. Through his association with the Apostles the bonds of community and friendship took precedence over most other values. Others have also recognised the influence of the Apostles on Keynes and his friend Lytton Strachey. For

\footnotetext{
${ }^{45}$ Hoover, (2005, p 2).

${ }^{46}$ Keynes, (1949, p. 96).

${ }^{47}$ Keynes, (1949, p. 82).
} 
example, Taddeo argues, Keynes' and Strachey's affiliation with the Apostles provides an important chapter in our understanding of the history of sexuality and masculinity in early twentieth-century England. ${ }^{48}$ Both regarded themselves as rebels whose devotion to Plato was part of their larger opposition to Victorianism. This generation 'renounced religion and politics, proclaimed the death of God, and declared "'love is the only reality.",49 What this also meant was that it was highly unlikely the Apostles would easily lose touch with one another. In fact, Moore's 'highest good' proved strong enough to withstand the requirements of making a 'regular' living. Many of the Apostles of Keynes' generation settled in London in close proximity to each other, and from the original 'at homes' of some of them a new association eventually sprang up, looser than the Society, but one that, in time, would be a very important force in the cultural life of Britain. Those individuals who became the core of what is now known as Bloomsbury, were the third significant influence on Keynes, which stood for changing the cultural values of the nation away from utilitarianism and towards Moorean ethics. They were in the anti-Benthamite tradition of writers who viewed themselves as having a mission to teach higher values to the masses, and especially to prevent them being swallowed up by the crassness of a commercial civilization. In time its members would conquer one field after another, giving new directions to art and art appreciation, to the novel, to history and biography and to political economy. Rosenbaum argues, 'the first bastion to fall to this cultural attack was aesthetics, the last was economics. ${ }^{, 50}$

In addition to his rejection of Benthamite utilitarianism, a commitment to Moorean ethics of community and friendship, and rebellion against Victorian mores and conventions, a fourth influence on Keynes was the application of a psychological mode of

\footnotetext{
${ }^{48}$ Taddeo, (2002).

49 Lytton Strachey to Leonard Woolf, describing the "truths" that he has discovered as an Apostle, January 19, 1906, Berg Collection, Strachey-Woolf Letters, 112 A. L. S., New York Public Library, from Taddeo, (1997, p. 197).

${ }^{50}$ Rosenbaum, (1975, p. 61).
} 
thinking about literature. This method relied on psychology as an explanatory tool and it will be argued in Chapter Eight that Keynes used this method in Economic Consequences. These influences on Keynes were different from the scholarly surroundings of Cambridge, and the public policy work of the Treasury, which helps explain why Keynes believed economics was more than a science. What is perhaps surprising is that he gained acceptance among economists in a way his close friend Strachey did not among historians. This was, argues Mini, due less to the broad-mindedness of economists than to the superior tactics of Keynes and to the pressure of the times. Before the methods of Strachey and his Bloomsbury contemporaries could exercise any significant impact on economists, Keynes' primary works had already been turned into a science. As a result, 'neither the Cambridge Circus nor the great Depression could save Maynard's method from becoming substantially warped, as many economists now recognise. ${ }^{51}$

In summary, cultural influences were important in helping explain the development of Keynes' ideas, his activities as a public intellectual, and his efforts at changing 'inner' and 'outer' opinions. The influences of Moore, Eton, the Apostles, and Bloomsbury underpinned the ways he viewed the workings of economics. These included the rejection of Bentham's harsh utilitarian views; his lifelong acceptance of Moore's ethics as the preeminent philosophical basis of friendship and community; and the application of a psychological way of thinking about literary characters that was innovative and helps explain the successful publications of Keynes, Strachey and Woolf. This mix of cultural influences also helps explain many of Keynes' unique and innovative insights, as well the success he enjoyed in disseminating his ideas to a wide audience. At times they were captivated, often convinced, and at other times captured by the controversy his activities as a public intellectual courted. Whether his ideas are judged as right or wrong, as good or bad science, balanced or exaggerated, what cannot be easily dismissed is the importance and place of culture in shaping and supporting Keynes in the communication of his ideas.

${ }^{51}$ Holroyd, (1995, p. 132). 


\subsection{The Communication of Ideas}

The discussion above highlights the importance of the public intellectual and cultural influences for economic ideas to be successfully communicated. A third factor, the dissemination process, is also important for effective communication. The nineteenth century was an important watershed for economics and literature, with both having an impact on the communication of economic ideas. Briggs argues this period shaped not just the way in which economics is now communicated but influenced the very idea of knowledge diffusion and the aim of reaching larger and larger numbers of people. ${ }^{52}$ The 1826 foundation of The Society for the Diffusion of Useful Knowledge highlights the phenomenon of knowledge diffusion. This organisation published inexpensive texts intended to adapt scientific and similarly high-minded material for a rapidly expanding reading public. The Society was founded three years after the London Mechanics' Institution and both put self-education at the heart of the communication process. Whereas the cultural ideal of the nineteenth century 'spanned arts and sciences, the verbal and the visual, factual information and speculation' by contrast, in the twenty-first century, specialisation separates the "two cultures" of the arts and sciences. ${ }^{53}$

This separation between the "two cultures" was taking place at the time Keynes published Economic Consequences. ${ }^{54}$ Briggs argues a cleavage had started by the late nineteenth century and marked a shift away from the 'generalist' and the 'integrated' age of knowledge dissemination to the specialised era that continues to the present time. This period saw the founding of the Daily Mail, which epitomises the rapid growth of mass

\footnotetext{
52 I have discussed above that the term diffusion took on a specialist meaning for economists to describe the dissemination of technological ideas toward the end of the nineteenth century. However, when discussing the nineteenth century itself the term held a broader meaning to mean the diffusion of any form of knowledge. Briggs, (1973).

${ }^{53}$ Briggs, (1973, p. 8).

${ }^{54}$ Snow, (1998).
} 
media in the twentieth century, the arrival of the young Marconi in Britain with his new wireless patents, the first motor race to be held between London and Brighton, and the first cinema show in London's West End. Briggs explains, 'you can see how the cultural bearings were changing. This, indeed, was a hinge [moment in time] between the cultures of the nineteenth and twentieth centuries. ${ }^{, 55}$ When considering the activities of Keynes it is possible to see how his works often reflect this transitional period. On the one hand the worlds of science and the arts were integrated holistically, as can be seen when closely examining Economic Consequences, but on the other hand Keynes embraced his role as a professional economist and wrote works for a specialist audience of economists.

\subsubsection{Information dissemination}

Those interested in the role information and knowledge dissemination play are typically interested in specific aspects or perspectives of the dissemination process. For example, when economists use the term "diffusion" they refer specifically to the spread of ideas around technology. Mokyr is one of many economists who focuse attention on the contributions of technological progress to the wealth and health of nations. ${ }^{56}$ Mokyr takes the notion one step further and develops a theory of "useful knowledge," which he argues is the foundation of technological progress. While Mokyr's analysis of economic exchange and performance is based on the central premise that a store of knowledge holds the key to explaining the spread of economic ideas, others are interested in how this store of knowledge, and the ideas that make it up, are disseminated. For example North places the role of institutions at the heart of his analysis of how economic ideas are communicated and spread. ${ }^{57}$

\footnotetext{
${ }^{55}$ Briggs, (1973, p. 14).

${ }^{56}$ Mokyr, (2002).

${ }^{57}$ North, (1990).
} 
Crémer is another scholar interested in the role of information and knowledge and its dissemination, but his approach is different again. ${ }^{58}$ His interest is in the role played by culture, corporate culture in particular, and he argues, the cognition and belief systems that constitute culture provide an environment crucial to the efficient flow of information. He argues it is the patterns of conditioned thought and ingrained routines that generate consistent behaviour and efficiencies in information processing. North and Barnard, who both stress the importance of cultural values and beliefs in shaping human activities and institutional preferences, share these views. ${ }^{59}$ Casson also subscribes to the importance of culture and argues that the existence of 'high trust' culture underpins transaction cost efficiencies. ${ }^{60}$ This is an important element for Casson in understanding the role information plays in the process of economic exchange. He argues it is a mistake to think of an economy in purely material terms when trying to explain the process of economic exchange. What really matters is the information and organisation underpinning the material economy.

While these scholars provide important perspectives and clues for an explanation of how economic ideas are communicated and spread, they all define the subject in narrow terms: Mokyr as the diffusion of technological ideas, Crémer, Barnard and North as the communication and spread of ideas from an institutional perspective, and Casson as a way of examining the role of information in the economic exchange process. However, the examination of how ideas are communicated and spread from economists to the public sphere does not enjoy the same degree of scrutiny and research. Among the reasons for this are the difficulties in measuring outcomes from the transmission and diffusion process. Most groupings making up the public sphere expect and demand simple and short explanations for what are invariably complex ideas. The result often ends in

\footnotetext{
${ }^{58}$ Crémer, (1993).

${ }^{59}$ Barnard, (1958).

${ }^{60}$ Casson, (1997).
} 
confusion, misunderstanding and incorrect reinterpretation of original ideas. For example, a professional economist's understanding of monetarism is usually different to how a member of the public would understand it. A second reason for difficulties of measuring outcomes from the communication of economic ideas to the public sphere resides in the nature of the political process. Lay publics in particular typically expect a high degree of certainty from politicians and the political process. Economic ideas, however, are often highly uncertain. Finally, there is the difficulty of measuring communication outcomes. As a profession economics has not developed high enough standards of robustness in testing theory against application in ways that enable people outside the profession to easily comprehend the ideas economists communicate, which is why Solow argues that economic ideas often turn to 'mush. ${ }^{\text {, }}$

If this is the case we may be facing a potentially insoluble problem and perhaps the public should just learn to trust professionals to get on with the job. But this would mean economists could neglect an important professional responsibility, namely the need to clearly communicate and inform, no matter how difficult the task, the implications and consequences of ideas that have an impact on members of the public. For example, we would deem it unacceptable for a medical professional to tell his or her patient they will not understand why they are dying. This is no different to an economist refusing to explain the consequences of monetary policy on living standards because the public will not understand monetarism.

However, there are difficulties in the transmission of economic ideas from the 'professional' economist to the public. Solow argues that while economic ideas are complicated the transmission process is often not designed to interpret complexity and is itself imperfect. By the time an economic idea reaches its ultimate destination it has been changed and distorted in one way or another. By way of example, Solow states the

${ }^{61}$ Solow, (1989). 
average person-in-the-street has probably never heard of monetarism and among those who have, the picture in their heads is very likely to be quite different from what an elementary textbook conveys, and certainly not what any professional economist would understand, 'let alone what a specialist in monetary macroeconomics would teach to graduate students. ${ }^{62}$ Solow believes there are at least three sources for this debasement of economic ideas as they diffuse into the public arena. First, debasement of economic ideas is inherent in the diffusion process itself. Economics is a complicated subject, whether we are talking about macroeconomics, microeconomics, theoretical economics, or applied economics. A meaningful answer to any serious question cannot be accurately stated in one or two short sentences. Yet, short answers is what the world wants, and 'by and large those are what it gets. ${ }^{, 63}$

The second reason for this debasement is inherent in the demands of the political process, and its relation to economic thought. In addition to 'good' economics being complicated, 'good' economics is also uncertain. Even when the underlying principle is clear its application to particular circumstances is never direct. Too many other things are always happening at once. A politician does not need complexity and uncertainty, just the opposite. Solow argues, 'this demand for simplicity and confidence is strengthened by the fact that the political process is rarely interested in narrow economic policy for its own sake. $^{, 64}$

There is a third problem and this is the economics profession. Theory tends to outrun sound applied economics. Theory is always proposing hypotheses of such a degree of fineness that data cannot seriously test them, verify them, or improve them, while 'we [professional economists] propose more and more elaborate ways to exploit the pitifully

\footnotetext{
${ }^{62}$ Solow, (1989, p. 75).

${ }^{63}$ Solow, (1989, p. 81).

${ }^{64}$ Solow, (1989, p. 82).
} 
few real degrees of freedom history gives us. ${ }^{65}$ The result is that answers to economic questions lack credibility and reliability because it is too difficult to align empirical evidence with theory. Having gone so far, we find ourselves forced to pretend to believe the answers we get. We have, according to Solow, ways of making the data talk, yes, but, 'like any tortured soul they can be made to say whatever the torturer wants to hear.' ${ }^{66}$ While Solow, as a professional economist, does not have ready answers to the first two problems, he does believe the profession can get its own house in order. Economists need to ensure the standards of evidence are made more robust. An honest economist, according to Solow, will insist on robust results, which can only be confirmed by consulting a wide range of evidence. Unfortunately Solow does not explicitly explain where current standards fall short nor does he explain how wider ranges of evidence should be gathered, nor the types of evidence that will meet the criteria of robustness. However, we probably expect too much, for the very reasons we have the problems associated with the transmission of economic ideas. There are no accepted sets of standards or types of evidence to enable measurement in a way Solow would like. This in turn highlights that, to date there has been little attention paid to the problems associated with the communication and spread of economic ideas from professional economists to the public. Without further research it is unlikely the standards Solow would like to see will emerge any time soon.

Within these constraints highlighted by Solow, one of the research objectives of this dissertation is to determine the degree to which economic ideas, especially those outlined in Economic Consequences, were reliably transmitted to the public sphere of Keynes' generation and in what ways his role as a public intellectual helped ease the transmission process.

\footnotetext{
${ }^{65}$ Solow, (1989, p. 82).

${ }^{66}$ Solow, (1989, p. 83).
} 


\subsubsection{Rhetoric and Economics}

To this point it has been argued a public intellectual plays an important role in the communication of ideas to the public sphere. Furthermore, to enable the public intellectual to successfully communicate requires a cultural environment receptive to their views, with suitable media for the communication and dissemination of their message. There are numerous means through which communications pass - works of literature, newspapers, journals, speeches, magazines, radio and film and all were available and used by Keynes to communicate his ideas.

The scope of this dissertation, however, is limited to literary works. There are several reasons for this: it would require a wider scope of inquiry to examine a larger range of media; Keynes, while utilising several different media, used literary texts as his primary means of communicating; and of the ideas he did communicate these were often reworked into subsequent literary texts. ${ }^{67}$ But accepting the place of literature in itself is not enough. The ways in which literature is constructed and the techniques used by writers enable ideas to flow beyond the author's pen. Most literary theorists refer to this as a 'writer's style.' We need, then, an explanation for how and why a particular style persuades an audience, where other writers' ideas are not as persuasive. Literary critics often examine the rhetorical nature of a text to establish persuasiveness. Furthermore, the ways in which metaphors, analogies and allusions are used, can provide important clues as to why a piece of literature is persuasive.

All communication, whether verbal, written, numerical or visual, attempts to persuade and can therefore be described as rhetoric. ${ }^{68}$ Clower argues that 'all communicable knowledge rests in the final analysis upon persuasive rather than

\footnotetext{
${ }^{67}$ A good example was the set of "Reconstruction Supplements" Keynes wrote for the Manchester Guardian during 1922. In Keynes' book A Tract on Monetary Reform, published in 1923, he drew heavily on his own contributions to the Supplements.

${ }^{68}$ Carruthers, and Espeland, (1991).
} 
demonstrative argument. ${ }^{69}$ Rhetoric was part of a classics education at the turn of the twentieth century, and generally regarded as a "body of rules," enabling a speaker or writer to "express himself with eloquence" and "to persuade or influence others."70 Economists have been somewhat slower than many other branches of the social sciences to accept they are rhetoricians. According to Davis such thinking for economists remains unfamiliar and uninteresting. ${ }^{71}$ Instead they cling to the notion their form of science is the opposite of the rhetorician's world-view. In short, they believe the language they use will faithfully report on matters of fact uncoloured by any personal or partisan agenda or desire.

\subsubsection{Rhetoric and Persuasion}

McCloskey argues mainstream economists do not like to think of themselves as employing rhetoric; rather they regard themselves as scientists whose methodology insulates them from the appeal of special interests or points of view. ${ }^{72}$ Such thinking imposes significant

${ }^{69}$ Clower, (1973, p. 10).

70 The "rules of rhetoric" have their roots in classical Greece and Rome. By the time of Cicero (106-43BC) Aristotle's early views of rhetoric had been divided into five major canons; inventio (invention); dispositio (arrangement); elocutio (style); memoria (memory) and pronuntiatio (delivery)

Invention: the art of discovering ways to find an argument that would persuade an audience.

Arrangement: the method of organising an argument.

Style: presenting an argument in a way designed to stir the emotions. Diction and organisation of phrases (tropes) became one's style. This was divided into three levels: low (teaching), middle (persuading), and high (entertaining).

Memory: the ability to use mnemonic devices to call forth and sustain an argument.

Delivery: without effective delivery the other canons will not matter.

Source: Worthington, (2007).

${ }^{71}$ Davis, (2003, p. 572).

72 McCloskey, (1986, p. xvii). 
constraints on matters of economic inquiry. For example, an examination of a work of literature such as Fitzgerald's The Great Gatsby, would pose a problem for mainstream economists. The novel, written by a non-economist with no economic agenda, is a story of financial loss and ruin that deals with day-to-day consequences of real individuals whom Fitzgerald knew during the inter-war period. Such a book would have no value to those interested in economic history if they held the view that the discipline of economics does not operate outside the field of deterministic science. But, economists such as McCloskey argue such a viewpoint is flawed. Whereas many mainstream economists think their discipline will produce 'knowledge free from doubt, free from metaphysics, morals and personal conviction,' no such knowledge, according to McCloskey, is available. ${ }^{73}$ For those who share McCloskey's view, impersonal method is both an illusion and a danger.

For literary critics such as Stanley Fish, economists were merely catching up when the first conference was called in 1986 to consider McCloskey's arguments:

Each of the objections [heard at the conference] had already been formulated (or reformulated) in those disciplines that had heard rhetoric's siren song long before it reached the belated ears of economists. One needs to go back to the publication of Thomas Kuhn's Structure of Scientific Revolution (1962) for the source of revolutionary change in methodological thinking; 'arguably the most frequently cited work in the humanities and social sciences in the last [thirty] years.' 74

The views expressed in 1986 are now shared by a number of economists working in the field of economics and economic methodology. For example Davis argues there has been a high rate of change in methodological thinking since Kuhn's book which, 'combined with the considerable diversity in ideas that now characterise the field, alone justifies our

\footnotetext{
${ }^{73}$ McCloskey, (1986, p. 16).

${ }^{74}$ Fish, (1995, p. 211).
} 
saying that the field is currently in a state of permanent revolution. ${ }^{75}$ This is a strong judgement but the challenge Kuhn poses for the nature of scientific enquiry is significant. McCloskey argues, rather than the notion of the "motor" of science being moved by verification or falsification, post-Kuhn science moves by persuasion. What this means is that the economist's mathematical models, statistical tests and market arguments, are all 'figures of speech - metaphors, analogies, and appeals to authority. ${ }^{76}$

Why economists have been such reluctant adherents to the notion their discipline moves by persuasion is somewhat mystifying. While this reluctance has no doubt been based on many economists' that view theirs is an objective and deterministic science, since at least Aristotle's time most scholars accept any appeal to authority carries with it the intention to persuade. For example, in the domain of appeals to statistics, mathematics, logic and objectivity Aristotle labelled this particular appeal to authority as "logos," which in simple terms means the use of reasoning, either inductive or deductive, to construct an argument. For example, when Keynes claimed, 'if the loans which the United Kingdom has made to her Allies are reckoned to be worth 50 per cent of their full value ... the operation would involve her neither in loss nor in gain,' he has made an inductive and logical appeal with the use of statistics and he wants to persuade his readers the operation would result in 'neither loss nor gain. ${ }^{77}$

\footnotetext{
${ }^{75}$ Davis, (2003, p. 572).

${ }^{76}$ McCloskey, (1986, p. xvii).

${ }^{77}$ Keynes, (1919, p. 255).
} 


\subsubsection{Discursive and Non-Discursive Rhetoric ${ }^{78}$}

Discursive communication is usually associated with verbal and written or printed text and includes the kind of language-making in which we "string out" our ideas. It relies on language to be ordered, sequential, and adhering to the "laws of reasoning" often assumed to be synonymous with the "laws of discursive thought." ${ }^{79}$ Discursive texts often take the form of the expository essay, the oral presentation, research and argument papers, and common modes such as narrative and description. The primary limitation of discursive forms of rhetoric is that they assume the word is the only means to articulate thought and anything which cannot be conveyed by discursive means is mere feeling, or too "fuzzy" for serious study. Murray argues, 'the discursive, therefore, is commonly referred to as "verbal" or "written" communication because, like this paragraph and texts [such as Economic Consequences,] it aims to convey one idea after another. ${ }^{80}$

Conversely, non-discursive communication is free of such ordering. The main differences from discursive communication are: it is primarily reliant on image; has an immediate impact; and is often employed to symbolise what cannot be said or written directly by the discursive ordering of words. Murray argues, rhetoric and the symbols we use for purposes of persuasion include more than the ordered, grammatical and codified linearity of discursive text. ${ }^{81}$ While it can be difficult to separate discursive from nondiscursive forms of symbolisation, because the line between the two is often blurry, 'both

\footnotetext{
${ }^{78}$ Susanne Langer was the first to define the terms "discursive" and "non-discursive" in Philosophy in a New Key: A Study in the Symbolism of Reason, Rite, and Art (1942) from Murray, (2009, p. 3). Joddy Murray is Associate Professor of Rhetoric and New Media at Texas Christian University. His interests are in language theory, new media, multimodal composition, and the affective domain - 'all of which come together in the rhetorical analysis of image and imagination.' Source: Personal website http://personal.tcu.edu/jmurray/.

${ }^{79}$ Murray, (2009, p. 4).

${ }^{80}$ Murray, (2009, p. 4).

${ }^{81}$ Murray, (2009, p. 11).
} 
have elements of each other to some degree. ${ }^{82}$ However, the advantage of considering non-discursive texts is that 'all possibilities of symbolization become tools for the rhetor: the symbols of math, music, textiles, food, poetry, commerce, violence, action, and even silence. $^{83}$

In Chapters Five and Six it will be demonstrated how Keynes used a variety of rhetoric, including conventional discursive writing but also poetry and statistics as explicit ways of persuading his readers. As a committed patron of the arts Keynes would have understood the difference between discursive and non-discursive rhetoric, and on those occasions where he appeared on film or radio, for example, he would have appreciated the immediacy with which non-discursive rhetoric could reach an audience.

\subsubsection{Metaphor, Analogies and Allusions}

Although Keynes' primary means of communication was discursive, his regular, and at times flamboyant use of metaphors, including analogies and allusions, demonstrates he understood the importance of symbolism and images which makes the metaphor, when used correctly, a powerful literary tool. According to the Princeton Encyclopedia of Poetry and Poetics the nature and definition of metaphorical terms and relations between them have "both been a matter for much speculation and disagreement. ${ }^{84}$ The metaphorical relation has been variously described as 'comparison, contrast, analogy, similarity, juxtaposition, identity, tension, collision fusion and different views have been held regarding nature, operation and the function of the metaphor. ${ }^{85}$ In recent years there has been a growing acceptance the metaphor is the

\footnotetext{
${ }^{82}$ Murray, (2009, p. 13).

${ }^{83}$ Murray, (2009, p. 13).

${ }^{84}$ Preminger,(1974, p. 490).

${ }^{85}$ Preminger, (1974, p.22).
} 
radical process in which the internal relationships peculiar to poetry are achieved; some critics maintaining that metaphor marks off the poetics mode of visions and utterances from the logical or discursive mode; other; usually anthropological evidence, that all language is metaphorical.

The traditional view of metaphor (in poetics and prose), however, is 'it is a figure of speech, or a family of tropes, involving two (and occasionally four) operative terms, and that it is used for adornment, liveliness, elucidation, or agreeable mystification. ${ }^{86}$

Frye refers to this metaphorical process as tapping into the "imaginative cosmos," which is neither the objective environment studied by natural science nor the subjective inner space studied by psychology. ${ }^{87}$ This 'imaginative cosmos' is a creation of the reading process itself. Frye argues, 'when we read (or otherwise examine) a verbal structure, our attention is going in two directions at once. ${ }^{88}$ One direction is centripetal, trying to make sense of the words we are reading. The other is centrifugal, gathering up from memory the conventional meanings of the words used in the world of language outside the work being read. The resulting "imaginative cosmos" in the reader's mind, is an 'intermediate world in which images of higher and lower, the categories of beauty and ugliness, the feelings of love and hatred, the associations of sense experience, can be expressed only by metaphor. ${ }^{89}$

This central place of metaphor in literature might best be explained by describing literature as the art and content of words. The student of literature might be interested primarily in the art of words or in the content of the words themselves. If the interest is in the content the student is drawn in the direction of linguistics and semiotics where, 'the

\footnotetext{
${ }^{86}$ Preminger, (1974, p. 490).

${ }^{87}$ Frye, (1990, p. xxii).

${ }^{88}$ Frye, (1990, p. 3).

${ }^{89}$ Frye, (1990, p. xxii).
} 
ordinary boundary terms that we commonly use within verbal structures begin to dissolve. ${ }^{90}$ On the other hand, if the art of literature is emphasised, rather than the words used, there is a common-sense practical distinction indicating an area of words different from other areas so that

in this distinction Keats, let us say, is a poet and not a philosopher, and Kant is a philosopher and not a poet. We recall Magritte's highly representational picture of a pipe, which he called "this Is Not a Pipe." A picture is a picture, and cannot be identified with or defined by its representational content. Similarly, a work of literature cannot be identified with what it says: whatever is "said" in literature belongs to ideology and rhetoric, not to the poetic as such. ${ }^{91}$

In simple terms the literary style is of interest to the student of the art of literature whereas it is content that interests the linguistics student. For example, we can examine Economic Consequences as a body of economic content and treat the book as a text on the proceedings and terms of the Treaty of Versailles and the economic consequences. Or, we can examine the book's style and in so doing uncover an entirely different layer of meaning, as we will see in Chapter Six. Frye argues that both elements, content and style, make up the language that intensifies consciousness and 'all intensified language sooner or later turns metaphorical, and literature is not only the obvious but the inescapable guide to higher journeys of consciousness. ${ }^{92}$ In simple terms again, the use of metaphor gives a literary work a certain 'style' but also intensifies consciousness because it gives meaning to content.

\footnotetext{
${ }^{90}$ Frye, (1990, p. 63).

${ }^{91}$ Frye, (1990, p. 63).

${ }^{92}$ Frye, (1990, p. 28).
} 
Of course "metaphorical" is 'as treacherous a conception' as "truth" or "reality" could ever be. ${ }^{93}$ Some metaphors are illuminating; some are merely indispensable; some are misleading or lead to illusion; some are socially dangerous. For example, 'Wallace Stevens speaks of "the metaphor that murders metaphor." But for better or worse it occupies a central area - perhaps the central area - of both social and individual experience. ${ }^{94}$ Frye argues it is a primitive form of awareness, established long before the distinction of subject and object became normal, "but when we try to outgrow it we find that all we can really do is rehabilitate it. ${ }^{95}$

\subsubsection{Economics and Literature}

It has been highlighted that the nineteenth century casts a long shadow over the twentieth as it was a crucial period for both the development of economics as a discipline and the first serious attempt at disseminating economic ideas to wider audiences beyond scholarly communities, a process closely linked to the development of literature and learning. Bigelow argues a major shift in thinking about economics took place during this period and modern economic theory was 'formed not simply in the private studies of Victorian political economists, but in a broad matrix of philosophical literary debate.' ${ }^{96} \mathrm{He}$ supports this argument by examining a number of literary texts, specifically novels, from the Victorian era. These include Dickens' Bleak House and Elizabeth Gaskell's Mary Barton, Cranford and North and South ${ }^{97}$. Based on these works Bigelow traces how an idealised

\footnotetext{
${ }^{93}$ Frye, (1990, p. xxiii).

${ }^{94}$ Frye, (1990, p. xxiii).

${ }^{95}$ Frye, (1990, p. xxiii).

${ }^{96}$ Bigelow, (2003, p. 73).

${ }^{97}$ Bigelow also examines the place of Ireland at this time and the economic issues resulting from the Potato Famine. He draws on two books by Nicholson to examine the spread of economic thought resulting from the famine in Ireland. Nicholson was an American Protestant evangelist and abolitionist who travelled from New York to Dublin for the purpose of “investigating the poor." Source: O'Riordan, (2010).
} 
view of economics developed into an appreciation by economists of how an economy functions. This emerging "romantic" vision of markets and market forces, over time, moved from an idealised world to views that ultimately helped shape modern economic theory.

Klaver also recognises the importance of the nineteenth century literary influence on the communication and spread of economic ideas. Her analysis attempts to contest the traditional histories that trace the progress of economic thought, through the increasing rationalisation, mathematisation and specialisation of economic theory from Adam Smith and David Ricardo through Jevons and Alfred Marshall. This is because, she argues

in nineteenth century culture, theories about the social - including production, distribution, and consumption of material wealth - found little support when they were not embedded in the very discourses of morality, providentialism, and nationalism from which, according to such histories, economic theory had already been disaggregated. ${ }^{98}$

The nineteenth century is, according to Klaver, a complex moment in the history of economic discourse with three threads constituting the significance of this complexity. First, there is the emergence and convergence of scientific and economic modes of thought in such ways that scientific forms of knowledge about the economy began to attain a new kind of cultural authority. Second, this convergence took a number of material discursive forms from the time of Dickens' novels, which often contested the authority of political economy, through to the time of Jevons' mathematisation of economic theory and to a point at which economics became its own discipline free from political economy. The third thread in this critical historical moment is the discourse of morality, ethics, and virtue. Klaver sets about her task by laying out the basic history and historiography of classical or scientific political economy, beginning with a discussion of Ricardo rather than Smith as, she believes, Ricardo more than any of the political

\footnotetext{
${ }^{98}$ Klaver, (2003, p. xi).
} 
economists who preceded him, attempted to separate economic concerns from their broader moral, social and political contexts. Klaver shows how John Ramsey McCulloch successfully adapted Ricardian theory to more familiar genres and more readable prose but in the process altered the content of Ricardian economics. While Ricardo strove to be aggressively amoral, McCulloch's writing relied on large narrative structures that explicitly remoralised the stakes of profit and loss and of scientific knowledge itself. McCulloch created for economic theory a moral urgency that appealed directly to his reader's beliefs and fears. However, in successfully reaching a non-specialised public, McCulloch transgressed 'Ricardo's most fundamental economic laws.' ${ }^{\text {99 }}$

Another Victorian contemporary of McCulloch, Harriet Martineau, also had ambitions for educating the public. She wrote twenty-five novellas with the aim of illustrating the whole science of political economy, beginning with its basic definitions and principles and continuing through the more complex permutations of economic law in the final volumes. But, like McCulloch, Martineau's novellas often distorted the underlying economic theory. Whereas Martineau's novellas could appeal to an even wider range of readers than McCulloch, 'their reliance on the conventions of popular narrative fiction further complicated the theoretical core of her message. ${ }^{\prime 100}$ Because the generic conventions of such fiction were so far removed from the scientific tradition in which Ricardo's ideas were developed, Martineau's stories were riddled with tensions between the formal demands and expectations of the divergent traditions. Both Martineau and McCulloch's writings also had the effect of placing economic theory back within the moral, social, and political discourses from which Ricardo had so painstakingly isolated it. This

\footnotetext{
${ }^{99}$ Klaver, (2003, p. xxv).

${ }^{100}$ Solow, (1989, p. xxv).
} 
reinforces Robert Solow's concern that when attempts are made to spread ideas to the public, especially the lay public, they often end up as 'ideas that turn to mush.' ${ }^{101}$

Kaufmann argues, the communication of ideas was directly affected by the rapid growth and institutional consolidation of commercial capitalism during the nineteenth century. ${ }^{102}$ Demand for new descriptions and explanations of the economy, state morality, and citizenship grew with the increasingly rationalised public sphere. Kaufmann finds it no surprise that the 34-year period between the publication of Malthus's first Essay and The Great Reform Act was the same period when economics and the novel gained intellectual and critical respectability. The forces that unleashed the demand for literary explanations included periodic depressions, the agitation for Catholic emancipation, general institutional reform and the later repeal of the Corn Laws. These together questioned the legitimacy of existing institutions and helped pave the way for writers such as Keynes to continue in the tradition of nineteenth century literary explanations but to also propose change and reform in new and fresh ways.

An examination of the works of Bigelow, Klaver and Kaufmann ${ }^{103}$ demonstrates there is a rich tradition of economic writing that reaches back to professional economists such as Ricardo, Malthus, Jevons, Marshall, Malthus and Mill as well as novelists such as Dickens, Gaskell, Martineau, Carlyle, and Ruskin. It also highlights how the nineteenth century holds an important place for literature and the communication of economic ideas to wider audiences. Keynes respected these traditions, which is especially clear when examining Economic Consequences. However, as Chapters Five to Seven demonstrate,

\footnotetext{
${ }^{101}$ Solow, (1989).

${ }^{102}$ Kaufmann, (1995).

103 In addition to Bigelow, Klaver and Kaufmann; Pettit (2004), Shell (1993), and Henderson (1995) provide some interesting insights into the importance of the nineteenth century for the development of literary economics.
} 
while Keynes built on this foundation he did so in innovative and new ways of writing about economics.

Page 93

8-Jun-11 


\subsection{The Tradition of the Communication of Economists' Ideas}

As was the norm, and highlighted above, Keynes received training in the classics and would have been taught the importance of the "rules of rhetoric." ${ }^{104}$ That he went on to apply what he learned is without dispute. Keynes was explicit in attempts at persuasion and "expressed himself with eloquence." As if to make the point, in 1931 Keynes published in one book, Essays in Persuasion, a selection from his attempts at persuading public opinion. But Keynes' training in the classics and use of rhetoric as means of persuasion, were not unique for an economist. Keynes stood on the shoulders of some important individuals, which raises the question, what can usefully be learnt from studying the activities of economists who explicitly sought to communicate their ideas? Such an examination also enables us to address one of Collini's concerns. Unlike some scholars who date the activities of public intellectuals to the Dreyfus Affair in France, Collini argues, intellectuals often played a public role well before the nineteenth century. ${ }^{105}$ Furthermore 'there can be no doubt that at the beginning of the twenty-first century the term itself is alive and well and living in the English language. ${ }^{106}$

An examination of a selection of Keynes' predecessors and contemporaries reveals at least five who meet Collini's criteria for a public intellectual: Adam Smith (1724 to 1790), David Ricardo (1772 to 1823), John Stuart Mill (1806 to 1873), Karl Marx (1818 to

\footnotetext{
${ }^{104}$ Moggridge, (1992, p. 44). Moggridge notes that the heart of the curriculum at Eton was classics. While Keynes requested more time for mathematics and Henry Marten, who arrived at Eton in 1895 was the first master specialising in history, 'classics still took most of the student's time.'

${ }^{105}$ Collini, (2006, p. 27). Collini provides a history of both the word 'intellectual' and the Dreyfus Affair as the time period in which commentators and scholars increasingly talked of the role of an intellectual in the public sphere. He agrees with most scholars that the Dreyfus Affair brought into currency the term Public Intellectual but leaves open the fact that intellectuals played an important role in society throughout the sixteenth and seventeenth centuries even though they have traditionally not been referred to as public intellectuals.

${ }^{106}$ Collini, (2006, p. 40).
} 
1883), and Alfred Marshall (1842 to 1924). All had achieved intellectually; all spoke to the publics of their day using the available information channels; all established reputations for saying important and interesting things on the general concerns of the public; all became leading cultural figures (as far as economics is concerned); all created original economic ideas; and all became shapers of opinion. 


\subsubsection{Adam Smith}

The intellectual achievements of Adam Smith are well documented with his best known book being An Inquiry into the Nature and Causes of the Wealth of Nations (Wealth of Nations). Published in 1776, 'this book is said to have established economics as an autonomous subject and, at the same time, to have launched the doctrine of free enterprise upon an unsuspecting world. ${ }^{107}$ While this seminal book is viewed as the first comprehensive system of political economy Smith could be regarded more as a social philosopher than one of the founders of economics. Smith's economic writings constitute only the 'capstone' to an overarching view of political and social evolution. When this masterwork is viewed in relation to Smith's earlier lectures on moral philosophy and government, to allusions in The Theory of Moral Sentiments (1759) for a work he hoped to write on the "general principles of law and government, and of the different revolutions they have undergone in the different ages and periods of society," 'then The Wealth of Nations may be seen not merely as a treatise on economics but as a partial exposition of a much larger scheme of historical evolution. ${ }^{108}$ Furthermore, with the publication of The Complete Works and Correspondence of Adam Smith (1976-81) by the University of Glasgow new light has been thrown on Smith's total output, and this suggests he was 'a system-builder on a grand scale, ${ }^{109}$ something more than just an economist. Nevertheless, The Wealth of Nations is the record of Smith's most mature thought and was the most comprehensive attempt in his lifetime to analyse the workings of "commercial society," as it was then called, or the "capitalist economy," as it is now called. The book laid down a mode of treating questions of value and distribution that shaped the

\footnotetext{
${ }^{107}$ Blaug, (1986, p. 232).

${ }^{108}$ McHenry, (1992, p. 308).

${ }^{109}$ Blaug, (1991, p. ix).
} 
entire course of economic thinking until the "marginal revolution" of the 1870s, 'founding, in fact, a distinct school of English classical political economy. ${ }^{110}$

While this contribution to economics is an important and lasting one, if Smith's role as a public intellectual is to be better understood, an examination of how he was received in his own time and what accounted for the popular success he enjoyed, is also needed. One of the first instances of his coming to the public's attention was in 1748, at the age of 25, when invited to give a series of public lectures in Edinburgh, with the support of three men - the Lord Advocate, Henry Home, Lord Kames, and a childhood friend, James Oswald. The lectures, which are thought to have been primarily concerned with rhetoric and belles lettres (in today's parlance, literary criticism), earned Smith $£ 100$ a year and are thought to have been of a wide-ranging nature. ${ }^{111}$

His reputation as a lecturer soon led to election to the Chair of Logic at Glasgow University, again with the support of Lord Kames. According to John Millar, Smith's most distinguished pupil, much of his time was devoted to the delivery of a system of rhetoric and belles lettres, which was based on the conviction that the best way of

explaining and illustrating the various powers of the human mind, the most useful part of metaphysics, arises from an examination of the several ways of communicating our thoughts by speech, and from an attention to the principles of those literary compositions which contribute to persuasion or entertainment. ${ }^{112}$

A set of lectures discovered by Lothian in 1958 , relate to a lecture session during $1762 / 3$ and show the concern Smith had with such problems as the development of language,

\footnotetext{
${ }^{110}$ Blaug, (1991, p. ix). Smith, was of course Scottish so it is curious that Blaug should lay claim to his being English. Nonetheless, Smith could be regarded as the founder of a distinctly British school of classical economy.

${ }^{111}$ Smith, Correspondence, letter 25, dated 8 June 1758.

${ }^{112}$ Skinner (2008).
} 
style and the organisation of forms of discourse which include the oratorical, narrative and didactical. Eatwell argues 'Smith was primarily concerned with the study of human nature and with the analysis of the means and forms of communication. ${ }^{113}$ Smith's $^{\prime}$ lectures on language were also published in expanded form as Considerations Concerning the First Formation of Language, in the third edition of the Theory of Moral Sentiments in 1767. The first edition of this book in 1759 was well received by both the public and Smith's friends. Hume, a close friend of Smith's, reminded him of the futility of fame and public approbation, and having encouraged him to be a philosopher in practice as well as profession, wrote:

Supposing therefore, that you have duly prepared yourself for the worst by these Reflections; I proceed to tell you the Melancholy News, that your book has been most unfortunate: For the Public seem disposed to applaud it extremely (Correspondence letter 31, dated 12 April 1759.) $)^{114}$

This book was to establish Smith's reputation with revised editions in 1761, 1767, 1774, 1781 and $1790 .^{115}$

Wealth of Nations was published on 9 March 1776, and once more received a warm response from Hume:

Dear Mr. Smith: I am much pleas'd with your Performance, and the perusal of it has taken me from a State of great Anxiety. It was a Work of so much Expectation, by yourself, by your Friends, and by the Public, that I trembled for its Appearance; but am now much relieved.

\footnotetext{
${ }^{113}$ Skinner (2008).

${ }^{114}$ Skinner, (2008).

${ }^{115}$ Keynes would most certainly have known of Smith's fame and the warnings by Hume of the pitfalls associated with fame and public approbation. No doubt this would also have struck Keynes as somewhat ironic as his publisher, Macmillan, had not expected Economic Consequences to be a best-seller. (Source: Cairncross, ODNB, 2004, 34310).
} 
Not but the Reading of it necessarily requires so much Attention, and the Public is disposed to give so little, that I shall still doubt for some time of its being at first very popular (Correspondence letter 150, dated 1 April 1776). ${ }^{116}$

In fact, the book sold well, with subsequent editions in 1778, 1784, 1786 and 1789 . Price argues that 'unlike the mass of economic writing [Wealth of Nations] established itself in the affections of the layman as well as the expert' and enjoyed its status as a 'classic' piece of literature and 'a crown of abiding glory.' 117

Price believes there are two reasons for this. First, the book is a literary text as well as a scientific treatise. This approach has its critics and as Price acknowledges there are those who say 'Political Economy in its scientific character has suffered from the literary treatment, which it has often received at the hands of practiced writers, who wield the effective instrument of a facile pen.' Such critics argue, the accuracy of reasoning is sacrificed to 'finish of expression' and has permitted sciolists to enter the domains of science. While Price also argues Smith would most likely have shared these concerns, nevertheless, Wealth of Nations 'has a charm in its composition which reveals the literary artist, and that the happiness of many of its phrases has aided the recollection of what would otherwise have been speedily forgotten.' Its language is simple and clear with an unmistakable reality in his writing. Furthermore, Price argues, despite the drawbacks of the literary approach 'the layman will concern himself more closely and frequently with [a well written composition] than with most other sciences, and that he will be attracted by grace, and deterred by awkwardness of composition.' 118

\footnotetext{
${ }^{116}$ Skinner, (2008).

${ }^{117}$ Price, (1893, p. 240).

${ }^{118}$ Price, (1893, p. 240).
} 
Second, despite the temptation to do otherwise, Smith adheres to the principle of 'scientific exactitude.' Smith kept focused clearly on the exposition of the theory of economics, which 'must be carefully distinguished from its application in practice ... the 'theoretical expositor' must sternly preserve himself from the dangerous and deteriorating influence of motive or purpose of a practical nature. He must pursue truth and truth alone, turning neither to the right hand nor to the left.' Price also argues Smith's 'one dominant motive and one ruling purpose' was his 'passion' for freedom. Not only does this, in Smith's case, 'render the writer a cogent arguer but means his readers are willing listeners which lends a force to his book in the form of accurate reasoning. ${ }^{119}$ In short, Smith did not compromise his science to literary gimmicks but rather blended his commitment to his science with knowledge that good literary technique is essential to communicating ideas.

When comparing Smith to Keynes there are many attributes that ensured similar success in the communication of their ideas. First, as intellectuals, both Smith and Keynes performed a public role reaching out beyond the discipline of economics. They both used available communication channels so as to spread their ideas, especially in the area of literary output where their ideas were most effectively disseminated. They also expressed views that concerned the general public and both enjoyed a track record of saying important and interesting things on the general concerns of the public. Both understood the importance of rhetoric as the means for persuading their reading public(s): Smith was a teacher of the subject while Keynes explicitly stated its importance in communicating his ideas. And, both were criticised for putting literary method ahead of their scientific principles, yet were able to demonstrate their commitment to scientific exactitude did not come at the cost of communication methods. On the contrary both men found a way to span the two cultures of art and science, thus enabling them to spread their ideas beyond an élite group of similarly minded economists.

${ }^{119}$ Price, (1893, p. 242). 


\subsubsection{David Ricardo}

Whereas Smith won the hearts and minds of contemporaries and the lay public through the way his ideas were presented, in language they could understand and through his public visibility, Ricardo achieved public fame in quite different ways. This is all the more remarkable because 'among the post-Waterloo political economists the advocates of the complete Ricardian case were almost ludicrously few.' So uphill was the task of conversion, Checkland argues, on Ricardo's death in 1823 James Mill could write to M'Culloch that they were his 'two and only genuine disciples. ${ }^{120}$ But he was well known during his own lifetime. For example, The Times, reported, shortly following Ricardo's death, 'Mr. Ricardo was one of the ablest men the country has seen for many years.' ${ }^{121}$

Ricardo's fame from 1815 onwards followed his gradual retirement from his position as jobber on the stock market and loan contractor for government stock. ${ }^{122}$ Ricardo's retirement coincided with Britain finding itself the leading industrial power of the day. Napoleon's defeat at Waterloo ended a quarter century of civil and international warfare and France ceased to be a threat to British leadership, finding themselves a diminished power in European affairs. Germany was a semi-feudal state without political unity and still half a century away from its own industrial revolution. The United States of America remained an economic colony of Great Britain long after it had won political independence so that 'in the century from 1815 to 1914 it was in a true sense a "British century" [whose] hegemony rested upon industrial supremacy [and] England the "workshop of the world"'123

\footnotetext{
${ }^{120}$ Checkland, (1949, p. 40).

${ }^{121}$ Barnes, Thomas, (24 October, 1823), “News," The Times, p. 2.

${ }^{122}$ Peach, (2008).

${ }^{123}$ Dillard, (1953, p. 95).
} 
However, the supremacy of Britain's lead remained under threat for the three decades following Waterloo. This threat to economic development came from within the country itself. Despite the Industrial Revolution, the majority of Englishmen still pursued rural occupations, and the landowning class still dominated political life. Agricultural and commercial interests struggled against the representatives of industrial capitalism throughout this period and in 1815 the focus of the struggle was upon the Corn Laws. Dillard argues that one of reasons for the popularity of Ricardo's doctrines 'lay in their practical usefulness to the industrial capitalist class, especially in the historic corn-law issue. ${ }^{124}$ Ricardo's views had been set down in a slim tract published in 1815 and entitled "An Essay on the Influence of a Low Price of Corn on the Profits of Stock." Within two years he published a more substantial work On The Principles of Political Economy. These were not the first times Ricardo had written on economic matters, for he had long been in correspondence with leading figures of the day, and as early as 1809 he had written an anonymous article on "The Price of Gold" for the Morning Chronicle. But, as Gudeman points out, Ricardo's renown as an economist undoubtedly dates from the period when he withdrew from active participation in the City of London and devoted himself more intensively to economic problems of the times.

Ricardo usually linked his theoretical constructions to topical issues, such as the price of bullion or taxation policies. Gudeman argues, 'in the history of economics perhaps only John Maynard Keynes rivalled Ricardo in the ability to combine an immensely successful financial career with political involvement and contributions to economic thought of the first magnitude. ${ }^{\prime 25}$ Like Keynes he was highly regarded for his work in the area of economic analysis. Both Ricardo and Keynes had become well known as a result of their writing on topical economic concerns of the day. Whereas Keynes achieved public attention following publication of Economic Consequences, Ricardo enjoyed a public

\footnotetext{
${ }^{124}$ Dillard, (1953, p. 95).

${ }^{125}$ Gudeman, (1984, p. 92).
} 
profile following his tract of 1815 . He also applied himself to the then pressing issue in England, the Corn Laws.

As the Napoleonic War drew to a close, conflict between the landowning and manufacturing classes was beginning to emerge. Landowners still dominated England at this time, but mechanisation had begun, and the iron, coal, and textile industries were growing. In the same period a series of poor harvests and an expanding population were combining to drive up the price of agricultural goods. In 1815 Parliament debated and passed a bill that put tariffs on the import of corn. Corn, which referred to small grains such as oats, wheat, and barley, was used to make bread and though estimates vary, bread probably constituted 40 to 60 per cent of a worker's total expenditure. ${ }^{126} \mathrm{~A}$ tariff on corn would make bread even more costly and either lower a worker's real wages or raise the wage cost to employers. Tariffs, then, were opposed by capitalists and labourers but were supported by landowners. In his essay, Ricardo devised a model to reveal the economic basis of this clash, and he used it to justify low tariffs and support for the capitalist class.

The literature on the Essay and its place within Ricardian thought 'is now substantial, and the interpretations are so various as not to admit of compromise. ${ }^{, 127}$ According to some observers the Essay represents the first time a model was used explicitly in economics. However, the success of Ricardo's Essay is that he drew upon and developed certain cultural styles of exposition so as to make the changing British experience understandable to his readers. Gudeman maintains, 'their use allowed him to communicate a vision of the economic process to a specific audience. ${ }^{128}$ Ricardo, however, offered the model as a faithful reproduction of the world, a mirror of the inner

\footnotetext{
${ }^{126}$ Gudeman, (1984, p. 92).

${ }^{127}$ Gudeman, (1984, p. 93).

${ }^{128}$ Gudeman, (1984, p. 93).
} 
workings of the economy. For him the model's usefulness lay in the precision with which it reproduced reality, and because the model was realistic it had a rightful call upon behaviour. Gudeman argues Ricardo intended his model to be used and for this to happen he needed to ensure it was a persuasive statement or 'pleasing' to his audience. He achieved this by presenting his model within a known style utilising paradox and in a way recognisable to the English public.

It would, however, be a mistake to leave a discussion of Ricardo with the impression that it was through his literary style he came to fame. Most agree with Hollander that what he describes as Ricardo's "mental dissociation" is what marks him out as the preeminent economic thinker of his day. Gudeman states, 'Ricardo was able to view - to the extent that no economist before or since has attained - a complex phenomenon, to single out therefrom one primary element, and to trace its ultimate course free from the modifying or counteracting influence of opposing forces. ${ }^{129}$ Hollander argues, the skill he brought to bear in his writing was 'devoid of literary skill either as to plan or style' but it was effective writing because of its compact phrasing and often 'paradox-like whip.'130 From James Mill, Ricardo had learned that which Rousseau had confessed to Hume and which Hume had repeated to Burke: "The secret of exciting the attention of mankind was the employment of paradoxes." Ricardo used paradoxical phrases such as; "the compatibility of a rise of wages, with a fall of prices;" "population always increases or diminishes with the increase or diminution of capital;" and "the landlord is doubly benefited by difficulty of production."131

However, as well known as Ricardo became through his own writing and model building, without the 'intellectual tenacity, the irrepressible enthusiasm, and the

\footnotetext{
${ }^{129}$ Gudeman, (1984, p. 93).

${ }^{130}$ Gudeman, (1984, p. 75).

${ }^{131}$ Hollander, (1911, p. 75).
} 
propagandist activity' of the group of friends, disciples and expositors who surrounded him, his views may not have become as widespread as they did. ${ }^{132}$ Whereas Adam Smith made political converts and Dugald Stewart aroused student enthusiasm, Ricardo 'won aggressive disciples. ${ }^{133}$ McCulloch was one such convert and almost from his first contact with Ricardo during June 1816, he became a 'prolific and energetic expositor.' From 1817 to 1827 he wrote economic articles for the Scotsman, and for two years (1818-1820) he was editor of the journal. He became principal economic reviewer of the Edinburgh in 1818 , and continued in this role for twenty years. He contributed important articles to the "Supplement of the Encyclopaedia Britannica" in 1818-24, and to successive editions thereafter. McCulloch conducted classes and gave lectures on the study of political economy in Edinburgh and London to 'large audiences of Noblemen, Gentlemen, Merchants, and others.' In 1824 he was the first Ricardo Memorial Lecturer, and in 1828 he was appointed to the chair of political economy in University College. He wrote many books and pamphlets, compiled useful manuals, and rendered important editorial services and 'for two generations, or certainly until John Stuart Mill's apogee, McCulloch was the veritable keeper of the economic conscience of England; and McCulloch's exposition was dogmatically, aggressively Ricardian. ${ }^{134}$

From this synopsis we once again see influences that were to play a part in shaping Keynes' literary style. For example, Keynes related to both Ricardo's rigid adherence to 'scientific exactitude' in developing his economic theories, while at the same time developing his own style of communication. While Keynes set out a different stylistic course, he remained cognisant of the importance of style in developing persuasive rhetoric. Furthermore, both men have cemented their places as public intellectuals because they both appealed directly to the public sphere by addressing economic

\footnotetext{
132 Hollander, (1911, p. 76).

133 Hollander, (1911, p. 76).

${ }^{134}$ Hollander, (1911, p. 75).
} 
concerns of the day. The only contrast between Ricardo and Keynes was that Ricardo's ideas were quickly taken up and disseminated by a group of disciples, something that only began to occur for Keynes almost twenty years following publication of Economic Consequences.

\subsubsection{John Stuart Mill}

Whereas Ricardo came to the attention of the public primarily through promotion by his disciples, Mill, like Keynes, achieved a public persona through his own endeavours. After a visit to Paris, during the autumn of 1830, when just 24, Mill became a regular contributor to the main periodicals and newspapers of the day. A series of articles on "The Spirit of the Age" appeared in The Examiner during 1831. From 1832 to 1833 he contributed many essays to Tait's Magazine, The Jurist, and The Monthly Repository. In 1835 Sir William Molesworth founded The London Review, with Mill as editor. It was amalgamated with The Westminster, as The London and Westminster Review, in 1836, and Mill continued as editor and later as proprietor, until 1840. During and after 1840 he published several important articles in The Edinburgh Review. Some of the essays written for these journals were reprinted in the first two volumes of Mill's Dissertations and Discussions (1859), which demonstrated the increasing width of his interests. ${ }^{135}$

During these years Mill also wrote his great systematic works on logic and political economy. His reawakened enthusiasm for humanity had taken shape as an aspiration to supply an unimpeachable method of proof for conclusions in moral and social sciences. Aside from the influences on him, such as the French positivist philosopher/sociologist Comte, the English scientist and mathematician Newton and British philosophers such as

\footnotetext{
${ }^{135}$ Among the more important are, "Thoughts on Poetry and Its Varieties" (1833), "Writings of Alfred de Vigny" (1838), "Bentham" (1838), “Coleridge" (1840), “M. De Tocqueville on Democracy in America” (1840), "Michelet's History of France" (1844), and "Guizot's Essays and Lectures on History" (1845). McHenry argues that 'the twin essays on Bentham and Coleridge show Mill's powers at their splendid best and indicate very clearly the new spirit that he tried to breathe into English radicalism.' McHenry, (1992, p. 135).
} 
Locke, Hume, Bentham, and his own father, James Mill, he was determined the new logic should not simply oppose the old. At the age of 36 he made a name for himself with the publication in two volumes of $A$ System of Logic, which was published in $1843 .{ }^{136} \mathrm{His}$ reputation was further enhanced in 1848 by his treatise Principles of Political Economy. ${ }^{137}$ He lived for a further 25 years, during which his authority as an economist was unrivalled in his own country. Blaug argues that throughout the last half of the nineteenth century, during almost the whole of the Victorian age right up to the publication of Marshall's Principles (1890), Principles of Political Economy was the leading economic textbook of the English-speaking world. According to Blaug it drew its enormous appeal from its extensive coverage of contemporary economic issues: its judicious blending of economic analysis and historical illustrations; from its masterful synthesis of Ricardian doctrine with many of the qualifications introduced by Ricardo's critics;

its radical tone contained within the orthodox framework; its elegant style, and from the reputation of Mill as a logician, philosopher, political theorist and belle lettrist. Here was no mere economist but a leading Benthamite, a 'saint of liberalism,' and a figure that towered over the intellectuals of his time in almost every area of debate. ${ }^{138}$

Following his retirement from official life, as head of the examiner's office of the British East India Company, until its dissolution in 1858, Mill published a series of books on ethics and politics partly written in collaboration with his wife. The essay On Liberty appeared in 1859 and the Thoughts on Parliamentary Reform in the same year. In his Considerations on Representative Government (1861) he systematised opinions already put forward in many casual articles and essays. Mill also began to write again on the wider philosophical questions that had occupied him in the Logic. In the same year he entered

\footnotetext{
${ }^{136} 3^{\text {rd }}-8^{\text {th }}$ editions, introducing a number of changes, were published between 1851 and 1872.

${ }^{137}$ Schwartz, (1968, p. 1).

${ }^{138}$ Blaug, (1991, p. 164).
} 
Parliament, 1865, he published both his Examination of Sir William Hamilton's Philosophy and Auguste Comte and Positivism. A news item from The Times of the same year illustrates how popular Mill had become:

Last evening the first public meeting called for the election at Westminster to hear Mr. John Stuart Mill was held in St. Jame's hall. The spacious hall was crowded almost as soon as the doors were open. Mr. Mill, on rising to address the meeting, was received with utmost enthusiasm. The people rose en masse, and waved their hats and cheered, and again and again renewed the cheers. ${ }^{139}$

Mill left Parliament in 1868 and retired to Avignon where he continued to write, with influence, until his death in 1873.

McHenry argues, Mill's legacy has continued and grown into modern times and his 'name continually crops up in philosophical discussions.' This is partly due to his offering a body of doctrine and a set of technical terms on many subjects, notably on induction, that have proved 'extremely useful in the classroom.' But a more important reason is that he has come to be regarded as a 'sort of personification of certain tendencies in philosophy that it is regarded as continually necessary to expound or expose because they make such a powerful appeal to serious minds.' ${ }^{140}$ Schwartz argues, as far as studying Mill's economic doctrine is concerned, the best course is to organise it around his theory of social and economic policy. Economics had acquired the reputation of being a cruel science focused on the acquisition of wealth through hard work and selfishness and 'in Carlyle's phrase, it was 'the dismal science." Mill wanted to change it into a doctrine of hope, one that was not merely reformist, as with his masters, but progressive in the widest sense of the word. His efforts at transforming it centred mainly on practical questions involving important theoretical innovations. Schwartz concludes, 'this attempt

\footnotetext{
${ }^{139}$ Delane, John, (July 06, 1865), “Election Intelligence,” The Times, p. 9.

${ }^{140}$ McHenry, (1992, p. 136).
} 
at transforming the character of economics must be the centre of any study of Mill's social thought. $^{\text {,141 }}$

Like Smith and Ricardo, Mill also established himself as an influential public intellectual who spoke out on numerous occasions on general matters of interest to the public. Like Keynes, Mill amassed an impressive literary output, influencing his and future generations. Furthermore, his concern and compassion in relation to social issues of the day meant he, like Keynes, bridged the cultural divide between science and art when communicating his economic ideas.

\subsubsection{Karl Marx}

Of all the economists with a public persona during their lifetime, Marx stands out as the most controversial figure. Bronfenbrenner argues, 'nowhere has he been easily forgotten, and Das Kapital (Capital) is still the most influential unread book in existence. ${ }^{142}$

Moreover many know him for his views and writings on philosophy and politics rather than economics. Blaug argues, 'It has become popular to say that Marx was no mere economist but an all-round social scientist who integrated economics, sociology, political science, history and even anthropology. ${ }^{143}$ There are few, if any elements, of his system which cannot be found in embryo in one or another predecessor. Marx's genius lay, 'like Keynes, in synthesis, in combining bits and pieces from one and another system into a whole greater than the sum of its parts. ${ }^{144}$ There are numerous books about Marx that hardly mention his economic ideas. Yet, in comparison to his writings on economics, Marx wrote very little on the concept of social class, the theory of the state, and the materialist conception of history. He did however write literally 10,000 pages on economics, which

\footnotetext{
${ }^{141}$ Schwartz, (1968, p. 4).

${ }^{142}$ Bronfenbrenner, (1967, p. 624).

${ }^{143}$ Blaug, (1991, p. 156).

${ }^{144}$ Bronfenbrenner, (1967, p. 625).
} 
was the only social science he professed to have mastered in all its aspects. Blaug argues, 'let there be no doubt, Marx was a great economist.' ${ }^{145}$ Even if we reject his fundamental Marxist schema and many, if not all, his central conclusions, Capital, in particular, contains much analysis from which modern economists can still learn. For example, Marx's list of economic concerns include: the growth of large-scale enterprise; the separation of ownership and control this entails; the functional role of unemployment as a method of disciplining workers under capitalism; the significance of changes in money wages in the course of the business cycle; the inherent periodicity of the business cycle; and the effect of technical progress. This is by no means an exhaustive list.

Most agree, however, while his writings are prolific and he displays the abstract power of economic reasoning reserved for just a few, such as Ricardo, his writing is convincing because of 'occasional flashes of brilliant rhetoric,' that anticipated Keynes. Furthermore, Marx is able in just a few pages to give vivid descriptions of the misery of the working classes under capitalism, and the apocalyptic vision that promised the demise of capitalism with all the confidence of a prediction in the natural sciences. ${ }^{146}$ Like Keynes, whose activities as a journalist contributed to his effective communication to the public, Marx's time spent in journalistic activities helped shape and hone the literary techniques underpinning his more academic reasoning and analysis.

While a student at the Universities of Bonn, Berlin and Jena he began to associate with the Young Hegelians, a group of intellectuals who were radicalising the philosophy of Hegel into a weapon of fierce social criticism. So inflammatory were some of his early articles Marx soon lost any chance of an academic career, turning instead to journalism. ${ }^{147}$ Forced to flee Germany in 1843 by the suppression of the newspaper he was editing, he

\footnotetext{
${ }^{145}$ Blaug, (1991, p. 156).

${ }^{146}$ Blaug, (1991, p. 156).

${ }^{147}$ Blaug, (1991, p. 154).
} 
settled in Paris, then Brussels, and finally in 1848 in London. He remained in London for the rest of his life, turning occasionally to journalism so as to alleviate the material misery he and his family lived in as well as trying to maintain his household in the middle class comfort to which they were accustomed. Despite the lack of any regular and sufficient income, he did have one relatively steady source of earned income in the United States, becoming The New York Tribune's European correspondent in 1851. The newspaper was sympathetic towards Fourier's utopian socialism. From 1851 to 1862 Marx contributed close to 500 articles and editorials, in which Engels collaborated in the writing of a quarter.

These journalistic contributions gave Marx a platform for explaining to the public his ideas on a variety of topical issues in addition to some of his more abstract and theoretical opinions with his contribution as a public intellectual coming primarily from the power of his writing. But times change rapidly, even in an author's own lifetime something sometimes conspires to make previous arguments seem out of touch. This is Neilson's argument when comparing Marx and Engel's pamphlet The Communist Manifesto with the appearance of the first edition of his magnum opus Das Kapital (Capital). In 1848 the Manifesto appeared at a time of social upheaval throughout Europe and its message seemed an appropriate clarion call for change. Manifesto enunciated the proposition that all history had hitherto been a history of class struggles and asserted the forthcoming victory of the proletariat would put an end to class society All forms of socialism were mercilessly criticised as being founded on philosophical "cobwebs" and "alienation." The avenues of "social utopias" were rejected as small experiments in community, deadening the class struggle and therefore were "reactionary sects." Ten immediate measures were set forth as first steps towards communism, ranging from a progressive income tax and the abolition of inheritances to free education for all children. The pamphlet closed with the, now well-known and famous words: "The proletarians have nothing to lose but their chains. They have a world to win. Workingmen in all countries, unite!" 
These messages resonated with many in 1848 but nineteen years later times had changed as the process of industrialisation affected the lives of many who previously subscribed to Marx's views. While Marx and his followers failed to acknowledge this process of change and its challenge to the relevance of Marx's views, the work of reform, particularly in Great Britain had undermined some of the theories Marx formulated and nearly all the conclusions he had arrived at. Neilson argues,

the improvement that took place in labour conditions between the time when the Communist Manifesto was issued in 1848 and the publication of Capital in 1867 made all the difference between the prophecies laid down in the former and the declarations he reached in the latter. ${ }^{148}$

Government statistics showed, and the annals of Parliament revealed, while Marx was writing, the conditions of the working classes were gradually improving. Moreover, in some areas workers were amassing capital of their own and starting businesses for themselves. This change went on fairly steadily for the next two generations, 'in spite of three depressions, [and] made the predictions ventured in the Communist Manifesto seem extravagant, if not absurd.' Co-operative societies, building associations, penny banks, and numerous other institutions fostered by the workers themselves were 'springing up in every direction. ${ }^{, 149}$ A strengthening and improving British economy was evidenced by a number of published statistics. For example, Parliamentary returns show the income tax in Great Britain for the year 1854 was $1 s 2 d$ in the pound. Twenty years later it was $2 d$ in the pound. In 1865 the national indebtedness amounted to over $£ 800,000,000$; thirty-five years later it had been reduced by $£ 160,000,000$. Neither of these indicators touched working class individuals directly, because working class people did not, for example, pay this income tax but with material improvements it is 'small

\footnotetext{
${ }^{148}$ Neilson, (1948,.p. 2).

${ }^{149}$ Neilson, (1948, p. 3).
} 
wonder that the British working man in those days did not accept the declarations and prophecies laid down in the Communist Manifesto.' This is not to say or infer the workingman had entered a paradise and was secure from poverty. But Marx had shown the working-man by his own efforts, without the cataclysm imagined by the authors of the Manifesto, could, if desired, make things better. ${ }^{150}$

If it seemed in his own lifetime Marx had failed to change with the times the coming conflict of 1914 to 1918 was to change everything and bring Marx a degree of popularity in death that he never achieved in life. This is somewhat ironic as Marx had not made explicit any prophetic links to war as a consequence of the inequalities about which he wrote, although some commentators argue his was a prophetic mission. ${ }^{151}$ Much the same as Keynes was a prophet when he argued further revolution and conflict would follow should the terms of the Treaty be imposed on Germany. Furthermore, both men used apocalyptic language as a way of presenting their views. Whereas Keynes' mission was to protect and preserve capitalism, albeit with reforms, his apocalyptic warning was that capitalism was significantly at risk of collapse due to the economic consequences of the Peace. Rothbard argues that Marx, on the other hand, had a vision of a new world order that needed to be ushered in through an apocalyptic end to human history, which had been a history of suffering, of class struggle and exploitation of man by man. In the same way as the return of the Messiah in Christian theology will put an end to history and establish a new heaven and new earth, so the establishment of communism would put an end to human history. ${ }^{152}$

In messianic religious movements, the millennium is invariably established by a mighty, violent upheaval, an Armageddon, a great apocalyptic war between good and evil.

\footnotetext{
${ }^{150}$ Neilson, (1948, p. 4).

${ }^{151}$ Parsons, (1964).

${ }^{152}$ Rothbard, (2009, p. 1).
} 
After this titanic struggle, a new millennium, a new age of peace and harmony and a new reign of justice, will be installed upon earth. Marx believed such an age was dawning and for him and other schools of communists, mankind, led by a vanguard of secular saints, would establish a secularised Kingdom of Heaven on earth. This was the sort of conflict and upheaval Keynes did not want but could see as inevitable. Both men had an apocalyptic vision of the world which was ultimately played out on the stage of the twentieth century, Marx and the success of communism during the inter-war period and Keynes who lived to see the unfolding conflict of World War Two.

Today almost everyone will have heard the name Marx, although he was, states Irvine, relatively 'unknown and unhated'at the time of his death. ${ }^{153}$ Compare this to Keynes who, following publication of Economic Consequences, became a leading public figure but until the recent credit crisis enveloping the global economy was relatively unknown outside the community of economists. The two men share in common an ability to write for a public audience, most certainly as a result of their journalistic careers. They also wrote works that drew on an apocalyptic genre, appealing to the imaginative cosmos' that an effective use of metaphor creates. The dissemination of both men's views owe much to the activities of their disciples as much as anything they did in their own lifetimes. Often the words and deeds of writers only remain known or become known because others take up their views, even if they may distort them in the process. As has been shown, Ricardo owes much of the spreading of his views to a group of dedicated followers in his own lifetime. Marx has enjoyed widespread diffusion of his ideas because of the dedication of Marxist disciples, although not in his lifetime. Keynes too, was to benefit from the work of disciples such as Harrod, Kahn and Robinson, the only difference being that, like Ricardo, these disciples took up their cause during the intellectual's lifetime.

${ }^{153}$ Irvine, (1946, p. 54). 


\subsubsection{Alfred Marshall}

Economists interested in Marshall's contribution to economics often talk of "Marshall's mission," by which they mean his commitment to social reform. ${ }^{154}$ Marshall himself explicitly states in his magnum opus, Principles of Economics, 'the dominant aim of economics in the present generation is to contribute to a solution of social problems. ${ }^{155}$ Keynes identified the core challenge for Marshall as being 'how to get rid of the evils of competition while retaining its advantages. ${ }^{156}$ Such was the depth of Marshall's commitment to alleviate the misery and degradation he observed among the English poor that his ethical speculations on these issues drove him into the economists camp. ${ }^{157}$ Levitt also argues his compassion for those who suffered from the 'exigencies of the dismal science,' never diminished from the first 1890 edition of his Principles through to its final revision in 1920. And he practiced what he preached, serving throughout his years on numerous Royal Commissions and for various causes to alleviate the plight of the poor and to improve the conditions of commerce that affected them. ${ }^{158}$

Marshall's view that economics could best address the social problems in society, also acted as the social reform driver, which defined his rhetoric and how he communicated his ideas. Groenewegen argues that, like Keynes, he did this by combining the roles of moralist, reformer scientist and even politician. All these roles were 'always combined, constituting the one in many, sometimes the many in one. ${ }^{159}$ He could preach

\footnotetext{
${ }^{154}$ Middleton argues that this phrase derives from Reisman (1990), the final volume in a trio of studies of Marshall's life and thought. Middelton, (1998, p. 105).

${ }^{155}$ Marshall, (1961, p.42).

${ }^{156}$ Keynes, (1924, p. 16).

${ }^{157}$ Schumpeter, (1941, p. 239).

${ }^{158}$ Levitt, (1976, p. 425).

${ }^{159}$ Groenewegen, (1995), p. 790.
} 
on the role of women, for the good of the race, and on free trade. He could moralise on the wickedness of gambling, the misplaced conspicuous consumption of the rich or the problems associated with alcohol. For example, when Marshall wrote to The Times in regard to published statistics on "Alcoholism and Efficiency," rather than taking an economist's viewpoint that alcoholism is a threat to efficiency, and so drunkards are to be avoided by employers, he challenged readers to see the problem as deeper than an individual being solely judged on his drinking problem, because people 'probably did not start with equal advantages. ${ }^{160}$ These moral campaigns also saw him advising on the political expediency of giving outdoor relief to the unemployed and the aged and inviting working-class leaders to Royal Commissions and other government advisory bodies. ${ }^{161} \mathrm{He}$ could also discourse dispassionately on the difference between the particular expenses curve and supply curve, on the irreversibility of increasing returns over time, and on the complexities of marginal cost in relation to value. He wrote letters to The Times and other newspapers on the role of the post office and on the morality of the blockade against Germany during the First World War. Groenewegen argues, 'in this way, he wished to serve his world, his nation, his students and his times.' ${ }^{162}$ This wish to be of service manifested itself in writing for the general public, whether it be theorist, businessman, or the philanthropic charity activist among the clergy in parish or bishop's palace.

Groenewegen argues this gave Principles the unusual distinction of being extensively reviewed in newspapers and periodicals and enabled his astonished publisher 'to compare the sales performance of his Industry and Trade to that of a 'shilling shocker.' ${ }^{163}$ For Marshall there was one overarching end, which was to elevate individual human dignity by lifting society's standard of living.

\footnotetext{
160 Marshall, Alfred, (July 1907), "Alcoholism and Efficiency," The Times, p. 12.

${ }^{161}$ Marshall, Alfred, (15 February, 1886), Letter to the editor, The Times, p. 13.

${ }^{162}$ Groenewegen, (1995, p. 791).

${ }^{163}$ Groenwegen, (1995, p. 791)
} 
Marshall, however, was no crusader for "amateur" economics; in fact he turned his back on the efforts of many of his "amateur" forebears, such as Martineau who sought to explain economic theory via novelettes. His commitment to the professionalisation of economics is well known and was itself enough to bring an end to "amateur economics." Yet his ultimate objective was to secure a more humane capitalism and for Marshall this had to be undertaken in a manner that did not undermine the scholarly detachment and impartiality at the core of the newly instituted British Economic Association (BEA). The association represented the infant scientific discipline of economics, in contrast to the discipline of political economy of the day, by ushering in an era of scientific exactitude to the discipline of economics.

While, as has been argued, it was his concern for social reform which underpins Marshall's Principles, it was his focus on economics as a profession that led to the publication of this influential text. Publication has led many commentators to consider Marshall one of the most influential economists of his time, one who largely shaped mainstream economic thought for the next fifty years. For example, Marshall strongly influenced the codification of economic thought and brought to the attention of the public a number of elements that today lie at the heart of economics. He expanded on and explained the use of demand and supply functions as tools of price determination, previously discovered independently by Cournot. He was also an important part of the "marginalist revolution." His contribution was the idea that consumers attempt to adjust consumption until marginal utility equals the price. Marshall extended these ideas with the theory of price elasticity of demand. In addition he identified quasi-rents as an important economic concept. Another contribution was to a branch of economics now called welfare economics where economic welfare is divided into producer surplus and consumer surplus. He used this idea of surplus to analyse the effect of taxes and price shifts on market welfare.

While there is little disagreement these are some of Marshall's major contributions to economics, there remains an element of mystery as to why he chose to denigrate, in both written and spoken word, his 'great impersonal ally to which he owed so much, Page 117 
mathematics. ${ }^{164}$ After all, as Schumpeter points out, Marshall was not only an accomplished mathematician but without mathematical analysis the transformation of the Smith-Ricardo-Mill theories into the modern engine of research could not have been accomplished. So, despite Marshall's refusal to admit the essential part a mathematical schema played in developing his theories, he 'hid the tool that had done the work., ${ }^{165}$ Of course, as Schumpeter argues, he had good reasons for doing this, as he did not wish to frighten the layman; he wanted to be "read by businessmen." He was also afraid, rightly according to Schumpeter, of setting an example that might induce people with a mathematical training to think that mathematics is all an economist needs. But the complication is that readers with no grasp of calculus cannot understand Marshall's economic language, nor can the reality be ignored that a clear understanding of economics requires mathematical training. If we try to resist these notions 'no good purpose is served by making [his readers] think that he can. ${ }^{166}$ Ironically, according to Schumpeter, it is because of Marshall's use of mathematics that what first strikes the theorist's eye is the neatness of his prose. Marshall's writing flows with an easy grace with 'all traces of effort disappearing from the highly polished surface. ${ }^{167}$ Theorems are elegantly put and proofs are simple and concise - in the skeleton appendix at least. Furthermore, Marshall's mathematical training disciplined even his verbal statements and also 'accounts for the charming simplicity of his diagrams. ${ }^{\text {, }} 168$ In short, mathematics matters if we are to understand why Marshall's prose was so effective.

\footnotetext{
${ }^{164}$ Schumpeter, (1941, p. 240).

${ }^{165}$ Schumpeter, (1941, p. 240).

${ }^{166}$ Schumpeter, (1941, p. 240).

167, Marshall, (1961, p. 469).

${ }^{168}$ Schumpeter, (1941, p. 241).
} 
But Marshall also recognised economics can be a complex subject and he tried to make it easier for his students to understand his arguments by using an abbreviated method of summarising paragraphs in the margins. In one example Marshall describes quasi-rent as

incomes derived from land as a special instance of the incomes derived from the possession of "any differential advantage in producing a commodity"; and although we are setting aside those aspects of the problem which are peculiar to agricultural land, and especially those which depend upon particular forms of land tenure; yet there have been so many misunderstandings on the subject, that it will be best to say something at once on the difference between the mode of action of competition in agriculture and in manufacture.

The margin summary becomes: 'Allowance has to be made in its proper place for the influence of different forms of land tenure.' ${ }^{169}$

While some view Marshall's economics as extensions and refinements of the works of Smith, Ricardo, Malthus and Mill, Marshall extended economics away from its classical focus on the market economy and instead put human behaviour at the centre of studies. Winch argues this was Marshall's most important contribution to economics and through this emphasis economics was brought into closer contact with major social questions of the day, including progressive intellectual tendencies, just as Mill had done before him and Keynes was to do later. ${ }^{170}$ Furthermore, it defined a different form of capitalism than proposed by Smith but also a different form of socialism than proposed by Marx. Marshall believed human equality can only arise when the spiritual state of human nature has significantly improved. The practical reformer sees the answer lies in co-operation, rather than socialism, as well as a recognition people in general, and businessmen in particular,

\footnotetext{
${ }^{169}$ Marshall, (1961, p. 469).

${ }^{170}$ Winch, (1996, pp. 23-24).
} 
once they have earned some basic minimum wage or profit, 'care for wealth more as an indication of successful achievement than for its own sake. ${ }^{171}$ In other words, the businessman should not be regarded as a "self-seeking outcast from the company of the saints," but rather as similar to other good, but not yet perfect, humans of the present age who, having secured the necessities of life, are fundamentally motivated by the desire for recognition of their work by their peers. And if businessmen could be characterised as seeking wealth merely because it was a mark of their business acumen and hard work, then it was not unreasonable to expect they would embrace measures other than money as tokens of their success.

When reflecting on Marshall's legacy as a public intellectual and an economist, his place in the tradition of economic communications can be summarised in the following ways. As an economist Marshall set in motion two fundamentally important patterns of thought that came to dominate economic thinking during the inter-war period; from Marshall onwards economics became a professional discipline, which prefers "scientificbased" advice as to how economic problems should be addressed; and his commitment to social reform has brought about a cleavage among economists that continues to the present day. The contradictory views of economics as a deterministic or a social science underpinned by human behaviour came to define Marshall's economics and rhetoric, a mix similar to Keynes', only expressed more cautiously than Keynes' often flamboyant style of presentation.

Keynes' own career was strongly encouraged by Marshall and without his influence he may not have become an economist. Keynes remained a life-long admirer of Marshall and as a fellow public intellectual Keynes adopted similar ways of communicating his message. Both men held to the principles of scientific exactitude, as Smith, Ricardo, Mills and Marx did before them. As with all these economists Marshall was popular with the

\footnotetext{
${ }^{171}$ Marshall, unpublished manuscript, “Economic History: Middle Ages I," Marshall Archive, Marshall Library, Cambridge University as cited in Cook, (2008, p. 35).
} 
public. Keynes wrote about one of Marshall's books Industry and Trade '[that it] was a remarkable success with the public. A second edition was called for immediately, and by the end of $1932,16,000$ copies had been printed. ${ }^{172}$ Also in common with the other economists examined, their success in the public arena owes much to their disciples, of whom Keynes was one of Marshall's more devoted. He wrote: 'it is through his [Marshall] pupils, even more than his writings, that Marshall is the father of economic science as it exists in England to-day. ${ }^{173}$

\footnotetext{
${ }^{172}$ Keynes, (CW, X, p. 229).

${ }^{173}$ Keynes, (CW, X, p. 224).
} 


\subsection{Summary - Intellectuals and the Communication of Economic}

\section{Ideas}

Keynes was explicit in his efforts at persuading others to adopt his views on a range of economic concerns. Furthermore he explained in some detail why he considered 'insider' and 'outsider' opinion to be important and why he put so much effort into persuading the élites (the insiders), who provided leadership in an economy, and the public (outsiders) whose lives were directly affected by the decisions and leadership of the insiders. From the time he entered the Treasury during World War One Keynes set about assiduously developing contacts with officials, politicians and industry leaders who he considered insiders. Rarely did Keynes miss an opportunity to impress his ideas on those he considered the élites with influence over economic matters. However, Keynes also recognised those on the inside were slow to see or accept the need for change so there was also an important place for directly appealing to outside public opinion. Indeed Keynes put as much effort into persuading public opinion through his activities as a journalist, writer and public speaker as he did to courting insider opinion.

These activities might suggest Keynes was a public commentator like any other, using a variety of media to convey his message. However Keynes' success in communicating his ideas marks him out as unique. Even before publication of Economic Consequences, he was an eminent economist and in his activities as a public intellectual stood on the shoulders of predecessors who were equally as eminent as himself. Smith, Ricardo, Mill, Marx and Marshall had all been successful public intellectuals. Their ideas had been communicated beyond the community of economists and they appealed to a public sphere, often bringing about fundamental change in how we understand economics. There were also important early cultural influences, which determined his successful communication style: an education at Eton with its anti-Benthamite views; his association with the Cambridge Apostles; the ethical views of G. E. Moore; his involvement with Bloomsbury; and the influence of Strachey and Woolf on his writing 
style - all contributed to his development of a unique, controversial and innovative approach to addressing economic issues.

Page 123

8-Jun-11 


\section{Chapter 4: Economic Context}

Economic Consequences dealt with European prosperity and issues of convergence before the war, something of the economic dislocation of the war itself and how Keynes believed Europe would be affected should the terms of the Treaty be imposed. This provides the economic context for the contents of the book, dealing with three sub-periods: 1870-1914 with what we now term the first period of globalisation; 1914-1918 are the war years, which are often studied from a military or political perspective. However, there is a growing body of scholarship interested in how relative economic strength was an important factor in the war's outcome; and 1919-1929, which provides the primary context for this inquiry. Context is important because, unlike many contemporaries, Keynes did not believe the world could be economically restored to pre-war conditions. However, he did believe Europe could rapidly be restored to a new prosperity. But politicians and leaders of the day, in his opinion, failed to grasp the economic significance and consequences of many of their decisions and actions.

Following the war politicians and economists did, however, often work tirelessly, for a return to pre-war economic conditions. But despite all efforts, good and bad, this decade was characterised by economic dislocation, turmoil, and instability. Economic growth was erratic and sluggish. Price stability had broken down and never satisfactorily addressed. Countries found they could not return to the gold standard and the stability of trading conditions. Inflation, deflation and in some cases, hyper-inflation, further damaged weakened economies. A large debt overhang from the war was exacerbated by the inability to get on top of rising deficits. If there was a view that such consequences were inevitable, Keynes did not share it. From the time of writing Economic Consequences he used every means at his disposal to call for change, reform and leadership. What frustrated him most was a conviction that none of the instability was necessary. The problems sprang, as far as Keynes was concerned, from a deceptively conceived Peace and until this wrong was righted Europe was headed for an economic apocalypse. Despite these feelings of pessimism, Keynes remained hopeful when he wrote his book that everything wrong with the Peace could be put right, the last chapter of his book suggesting a set of remedies he believed could put Europe and the wider world back onto the right economic track.

Page 124 


\subsection{Background}

Most present-day scholars believe that the processes of divergence and convergence, associated with the first age of globalisation from 1870 to 1913 , provide the best explanation for the outbreak of war in 1914. Berend, Craig and Fisher, Daudin, Moryrs amd O'Rourke, Federicao, Klovland, Nayar, Ronnback and Williamson all subscribe to this viewpoint and provide empirical evidence in support of their arguments. ${ }^{1}$ The process of globalisation can be traced to the industrial revolution (1760-1830) when Europe experienced an unprecedented period of economic growth. Adoption and development of a laissez-faire economic system was accompanied by the gradual development of a multilateral payments network that allowed the facilitation of trade and economic growth on a global scale. With the adoption of the gold standard in the early 1870 s, ease of convertibility and stability of exchange rates followed. This economic "virtuous cycle" continued to encourage material progress. The second industrial revolution of the late nineteenth century saw the widespread use of electricity for the first time, development and refinement of the internal combustion engine, with the consequent development of public transportation, and renewed modernisation of older technologies such as railways. Technology was also increasingly applied to agriculture so a well-fed population helped underpin economic growth. What is now considered the first period of globalisation (or as contemporary commentators labelled it, "internationalisation") took place during this period as national economies around the world became increasingly integrated.

\footnotetext{
${ }^{1}$ Berend, (2006).

Craig and Fisher, (1997).

Daudin, Moryrs amd O’Rourke, (2008 and 2010).

Federicao, (2010).

Klovland, (2005).

Nayar, (2003).

Ronnback, (2009).

Williamson, (2008).
} 
However, underlying this picture of growth and stability were cracks that widened as the early twentieth century unfolded. Nationalism and a drive for conquest of economically underdeveloped countries led to an era of colonisation and imperialism. The rich, industrialised countries, along with the rapidly industrialising United States, became rivals for world leadership. Inequalities and disparities began to undermine increasingly integrated economies because of the competitive drive for political and economic domination. The inability of poor countries, such as those in Eastern and South Europe, to achieve an industrial break-through added to global tensions.

The Long Depression, helped widen the cracks. ${ }^{2}$ It was so named because in some countries, such as Great Britain, it lasted from 1873 to 1896. Rather than being an outputbased depression most modern economists see this as a monetary depression, where falling prices had a deflationary effect at the same time as new technologies were transforming economies. For example, Kennedy shows how GNP was increasing for most of the major European countries at the same time as prices were in decline. ${ }^{3}$ Some researchers, looking for explanations for price falls while improvements in technology and economic growth were taking place, often look to the relationships between gold, silver and prices, associating variations in the volumes and values of precious metals as accounting for the recessionary nature of the Long Depression. Others argue it was the process of increasing productive efficiency and economic integration that accounted for falling prices at the same time as economies were growing. For example, in the case of Britain the 'competitive efficiency of other countries, itself a function of the progressiveness of industrialisation, played its part in the British depression. ${ }^{4}$ One of the

\footnotetext{
${ }^{2}$ Until recent times scholars have usually referred to the 1873 to 1896 depression as the Great Depression. However, so as to better distinguish this period from what is now called the Great Depression from 1929 to 1933, it is more common to refer to the 1873 to 1896 period as the Long Depression.

${ }^{3}$ Kennedy, (1989, p. 219).

${ }^{4}$ Beales, (1934, p. 74).
} 
more significant reactions of nations to the Long Depression was to resort to protectionism to protect faltering industries. However, this also had the effect of undermining growth, stability and co-operation between nations, 'because in those years Cobdenite free trade was abandoned in one country after another; the futility of the Cobdenite vision of universal peace resting on the basis of national interdependence had been thoroughly exposed. ${ }^{5}$ When war broke out in Europe, a number of these same countries had not brought down protectionist barriers.

While the Allies, led by Britain, France, and Russia, moved to halt what they saw as the ambitions of Germany and her allies, a number of factors underpinned these European nations' resort to arms. First, the process of industrialisation and globalisation underpinning growth and stability also increased demand for military resources, fuelling an armament industry and an unchecked arms race. Demand grew out of the development of the nation states that made up Europe and this provides a second explanation for Europe's resort to arms, which Kaldor labels 'wars of identity.' She argues that warfare since the early nineteenth century had been fought by those powerless to control the levers of globalisation and they expressed their reaction to the intrusion of new global forces by 'the invention, re-invention and contortion of identities' where identities are explained in terms of the rise of the modern nation-state. ${ }^{6} A$ third explanation was 'the fear of the consequences of failure to face the challenge of war itself. ${ }^{7}$ Britain, France, Germany, Russia and Austria-Hungary all felt their positions threatened in some way or other. The three great European empires, Germany, Austria and Russia, felt threatened by the national dissatisfactions of their minorities. All three

\footnotetext{
${ }^{5}$ Beales, (1934, p. 68). Beales' reference to Cobden, free trade and universal peace alludes to a strongly held viewpoint by Cobden and Bright, and the movement known as the Manchester School that enjoyed strong support during the middle to later part of the nineteenth century, argued that free trade among globalising nations would in turn lead to universal peace, nations having too much to lose economically by going to war.

${ }^{6}$ Kaldor, (1999, p. 76).

${ }^{7}$ Keegan, (1998, p. 18).
} 
were also troubled by demands for wider democracy. Not that democracy was a problem in Britain or France but the burden for them was the administration of vast overseas dominions in Africa, the Americas, Asia and the Pacific. While they were a source of national pride for both countries they were a 'spur to aggressive jealousy among their European neighbours. ${ }^{8}$ A fourth explanation for the view the seeds of war were a result of the process of globalisation was the weakness of the process of international arbitration. For example, when Britain reacted to what it saw as an unjustified threat to its century-old command of the seas, following Germany's decision in 1900 to build a fleet capable of engaging the Royal Navy in battle, an unchecked race to out-build Germany in modern battleships began. There had been discussions at the Hague in 1899 around stabilising a process for the arbitration of such matters but the great powers of the day made no effort to invoke the Hague provisions for international arbitration. ${ }^{9}$ A fifth explanation came from another failure, the failure to utilise important technological advances in communication. While modern communication technologies were an important factor in the advance of industrialisation and globalisation, Keegan argues 'the potentiality of modern communication failed those dedicated to waging war, [but] how much more did it fail those professionally dedicated to preserving the peace.' This was a tragedy and the diplomatic crisis that preceded the outbreak of war was due to

events [which] successively and progressively overwhelmed the capacity of statesmen and diplomats to control and contain them. Honorable and able men though they were, the servants of the chancelleries and foreign offices of the great powers in the July crisis were bound to the wheel of the written note, the encipherment routine, the telegraph schedule. The potentialities of the telephone, which might have cut across the barriers to communication, seem to have eluded their imaginative powers. The potentialities of radio,

\footnotetext{
${ }^{8}$ Keegan, (1998, p. 18)

${ }^{9}$ Keegan, (1998, p. 19).
} 
available but unused, evaded them altogether. In the event, the states of Europe proceeded, as if in a dead march and a dialogue of the deaf, to the destruction of their continent and civilization. ${ }^{10}$

In summary, it was the process of globalisation that helps explain why European powers set themselves onto a path of destruction. As the war drew to a close in 1918 a better understanding of these forces may have helped avert the Second World War and The Economist observed in October 1918, with some prescience as it turned out, that

we want a clean peace, and we want it not only in foreign but in domestic politics. Without such a peace at home and abroad the revival of a more terrible war between nations and between classes is inevitable, but it can never be achieved if the war's end is made the profiteer's opportunity, and under the plea of patriotism tariffs are introduced to swell the profits of protected manufacturers and increase the burden of the harassed consumer. We are coming to the great crisis of the world's history, and whether we take the right path or the wrong depends mainly on whether we look forward in a sensible or in a narrow and reactionary spirit. ${ }^{11}$

Just as economic factors were to determine a peace The Economist was anxious to avoid, so too economic factors ultimately dictated the outcome of the war. From the outset the Allies had the economic advantage. For example, in 1914 the Allies had a population 5.25 times greater than the Central Powers. Territory covered was 115 times greater and GDP was 2.9 greater for the Allies. By 1918 the gap for all three economic factors had grown even wider in the Allies favour.

\footnotetext{
${ }^{10}$ Keegan, (1998, p. 23).

${ }^{11}$ Withers, Hartley, (ed.), (October 12, 1918), "What Sort of Peace?" The Economist, p. 443.
} 


\subsection{The European Economy Pre-World War One}

The period from 1870 to 1914 represented the high-water mark of nineteenth-century globalisation that involved increasing transfers of commodities, people, capital, and ideas between and within continents. ${ }^{12}$ Prior to World War One, Britain, France, and Germany had less than a third of Europe's population, but produced $72 \%$ of the continent's industrial output, $93 \%$ of its coal, $78 \%$ of its steel, $80 \%$ of its engineering, and $74 \%$ of its chemical products, and consumed $73 \%$ of its cotton imports. ${ }^{13}$ Writers and commentators of pre-1914 European history paint a nostalgic portrait of the economic status of these European countries and its people. Taylor argues

a sensible, law-abiding Englishman could pass through life and hardly notice the existence of the state, beyond the post office and the policeman. He could live where he liked and as he liked. He had no official number or identity card. He could travel abroad or leave his country for ever without a passport or any sort of official permission. He could exchange his money for any other currency without restriction or limit. He could buy goods from any country in the world on the same terms as he bought goods at home. ${ }^{14}$

Berend argues, 'by the early twentieth century, the Western European countries essentially ruled the world and forged ahead along their chosen path toward economic progress. ${ }^{15}$ Keynes observed

any man of capacity or character at all exceeding the average, into the middle and upper classes, for whom life offered, at a low cost and with least trouble, conveniences, comfort, and amenities beyond the

\footnotetext{
${ }^{12}$ Daudin, Morys, and O'Rourke, (2010, p. 6).

${ }^{13}$ Berend, (2006, p. 28).

${ }^{14}$ Taylor, (1975, p. 1).

${ }^{15}$ Berend, (2006, p. 19).
} 
compass of the richest and most powerful monarchs of other ages ... He regarded this state of affairs as normal, certain, and permanent, except in the direction of further improvement, and any deviation from it as aberrant, scandalous, and avoidable. ${ }^{16}$

Historians interested in Europe before the outbreak of war often have a tendency to paint similar nostalgic pictures of the "average" European to the ones above.

These nostalgic notions of a prosperous bygone age are supported by some compelling economic data. ${ }^{17}$ For example, by the middle of the eighteenth century Britain had achieved the prerequisites for sustained economic growth when British exports flourished, increasing 30-fold to $40 \%$ of the national income. By 1870 British exports reached $40 \%$ of the total Western European exports, and by World War One still accounted for one-third. During the first four decades of the nineteenth century industrial output grew at rates of $23 \%, 39 \%, 47 \%$, and $37 \%$ respectively. Britain gradually gave up agricultural self-sufficiency and from the 1840 s it, along with other European countries, steadily advanced towards free trade. This became institutionalised in Britain and through a series of agreements with Germany, Italy, Belgium, Sweden, Norway, Spain, Holland,

\footnotetext{
${ }^{16}$ Keynes, (1919, pp. 9-10).

${ }^{17}$ Most scholars interested in the industrial revolution, that began in parts of Britain, accept that the significant breakthrough into an industrialised age took place between 1760 and 1830 . This is to make a distinction from the actual process, the beginnings of which some scholars argue can be traced back to Tudor times with the first significant stirrings of political and economic freedoms as well as a gradual increase in democratisation and greater human rights. In Mokyr's most recent work on the subject he argues that the beginnings of the process can be traced back to the 'changing set of beliefs we associate with the Enlightenment' (Mokyr, (2010 p. 478)) that developed from the time of the Glorious Revolution. McCloskey follows a similar line as Mokyr but expands her explanation by arguing that it was the changing of attitudes and rhetoric towards the bourgeois, markets, and innovation, first in northwestern Europe and then in the rest of Europe, that heralded the changes in incentives and production necessary for industrial breakthrough and the emergence of the modern economy. McCloskey, (2006 and 2010).
} 
Austria, and Portugal, Europe effectively became a free trade zone during the third quarter of the nineteenth century. ${ }^{18}$

A phenomenon of the industrial revolution was the speed with which it moved through other European countries. This contagion of industrialisation quickly developed into a process of globalisation, with most economists accepting 1870 to 1914 marks a time when there was increasing transfers between and within countries of commodities, people, capital and ideas. Nayar argues economic globalisation is the expansion of the market to encompass the entire globe within its sphere. In other words, it represents the integration of various regional markets into a world market. The resulting divisions of labour and resulting specialisation make for greater efficiency and better economic gains. ${ }^{19}$ While there is some scholarly difference over the use of the term globalisation to describe the economic integration that took place between 1870 and 1913, what is undisputed is that the nineteenth century was marked by a remarkable explosion in the integration of the world economy through vastly expanded trade and foreign investment. This explosion was spurred on by a series of technological innovations in transport and communications, such as the railways, telegraph and steamship. ${ }^{20}$

Europe led the way and Craig and Fisher argue that by 1913 the continent, especially in the West, was so integrated in most important aspects of economic life it could be referred to as the major part of an international economy dealing in agricultural and manufacturing products, and experiencing movements of substantial capital and labour across borders. ${ }^{21}$ Later arrivals into the global economy essentially attached themselves to the existing European economic structures. An important precursor to this

\footnotetext{
${ }^{18}$ Berend, (2006, p. 11).

${ }^{19}$ Nayar, (2003, p. 4776).

${ }^{20}$ Nayar, (2003, p. 4777).

${ }^{21}$ Craig and Fisher, (1997, p. 272).
} 
economic integration was national political integration. Craig and Fisher have observed that every central European country, except Germany and Italy, was essentially politically unified, within its modern borders, by $1850 .{ }^{22}$ This, however, is a debatable claim as central Europe at this time consisted of four empires, Russian, German, Austro-Hungarian and Ottoman, which no longer exist, with national unity coming quite some time later. However, this aside, an increasing move towards national unity brought with it national economic policies of all kinds. For example, banking regulations, international monetary policy and political unity followed. National policies towards trade and capital flows in the form of regulation, subsidisation, excise and tariffs, all provided major interconnections across nations, which in turn meant nations could, to some extent, influence the direction and speed of economic growth.

Daudin, Morys and O'Rourke use a number of measures to illustrate how Europe over the period of 1870 to 1914 became increasingly integrated and in turn brought closer ties to the rest of the world. ${ }^{23}$ Their most straightforward measure of integration is the growing volume of international flows of commodities, people, capital and ideas. Another method used is to measure the cost of moving goods or factors of production across boundaries. The discussion below considers five of the more important elements of globalisation: trade; the multinational payment network; capital flows; migration; and the trade in knowledge.

\footnotetext{
${ }^{22}$ Craig and Fisher, (1997, p. 272).

${ }^{23}$ Daudin, Morys and O’Rourke, (2008).
} 


\subsubsection{Trade, $1870-1914$}

In 1990 prices, European international trade grew at $6.8 \%$ a year between 1870 and 1913 , with growth particularly high in Belgium, Germany, Switzerland and Finland (refer Table 1 below).$^{24}$ The European trade to GDP ratio, including intra-European trade, increased from $29.9 \%$ to $36.9 \%$, while excluding intra-European trade, increased from $9.2 \%$ to $13.5 \%$ (refer Table 2 below). European real trade 1870-1913

Table1 : European real trade 1870-1913

\begin{tabular}{lcc}
\hline & 1870 (million 1990\$) & Growth $1870-1913$ \\
\hline Austria & 467 & $+333 \%$ \\
Belgium & 1,237 & $+492 \%$ \\
Denmark & 314 & $+376 \%$ \\
Finland & 310 & $+415 \%$ \\
France & 3,512 & $+222 \%$ \\
Germany & 6,761 & $+465 \%$ \\
Italy & 1,788 & $+158 \%$ \\
Netherlands & 1,727 & $+151 \% 6$ \\
Norway & 223 & $+283 \%$ \\
Spain & 850 & $+335 \%$ \\
Sweden & 713 & $+274 \% 6$ \\
Switzerland & 1,107 & $+418 \%$ \\
UK & 12,237 & $+222 \% 6$ \\
\hline Weighted average & & $+294 \% 6$ \\
Weighted average, rest of the world & & $+379 \%$ \\
\hline
\end{tabular}

Source: Maddison (2001)

${ }^{24}$ Maddison, (2001, p. 362). 
Table 2: Exports plus imports as a share of GDP

\begin{tabular}{|c|c|c|c|c|c|}
\hline & 1870 & 1880 & 1890 & 1900 & 1913 \\
\hline Austria & $29.0 \%$ & $25.5 \%$ & 25.296 & $26.8 \%$ & $24.19 \%$ \\
\hline Belgium & 35.696 & 53.296 & 55.696 & 65.496 & 101.496 \\
\hline Denmark & $35.7 \%$ & $45.8 \%$ & 48.096 & 52.896 & $61.5 \%$ \\
\hline Finland & 31.796 & 50.896 & 39.396 & $47.6 \%$ & $56.2 \%$ \\
\hline France & $23.6 \% 6$ & $33.5 \%$ & $28.2 \%$ & $26.8 \%$ & $30.8 \%$ \\
\hline Germany & $36.8 \%$ & 32.196 & 30.196 & $30.5 \%$ & 37.296 \\
\hline Greece & $45.6 \%$ & $42.3 \%$ & 39.496 & $42.3 \%$ & $29.4 \%$ \\
\hline Hungary & 19.496 & 23.796 & 22.196 & 22.396 & $20.89 \%$ \\
\hline Italy & 18.396 & $18.3 \%$ & $15.9 \%$ & $19.0 \% 6$ & 23.996 \\
\hline Netherlands & 115.496 & $100.5 \%$ & $112.3 \%$ & 124.196 & 179.696 \\
\hline Norway & $33.9 \%$ & 36.196 & 43.696 & 43.496 & 50.996 \\
\hline Portugal & $33.7 \%$ & 43.896 & $45.3 \%$ & $48.9 \%$ & $57.4 \%$ \\
\hline Russia & & 14.496 & $15.0 \% 6$ & 11.496 & 13.896 \\
\hline Spain & 11.796 & 13.996 & $19.2 \%$ & 21.996 & $22.7 \%$ \\
\hline Sweden & 29.496 & 37.396 & 44.996 & 39.496 & $34.7 \%$ \\
\hline Switzerland & & $78.2 \%$ & $81.9 \%$ & $67.2 \%$ & $64.5 \%$ \\
\hline UK & $43.6 \%$ & 46.096 & $46.6 \%$ & 42.496 & $51.29 \%$ \\
\hline Best guess, European trade to GDP ratio & $29.9 \% 6$ & 33.496 & $32.6 \%$ & $31.9 \%$ & $36.99 \%$ \\
\hline Idem. net of intra-European trade & 9.296 & $10.7 \%$ & $10.8 \%$ & 11.196 & $13.5 \%$ \\
\hline
\end{tabular}

Notes: Ottoman Empire, Albania, Bulgaria, romania and Serbia not included

Source: Bairoch (1976)

Daudin, Morys and O'Rourke have also examined price data for the period and find evidence for 'impressive international integration. ${ }^{25}$ Between 1870 and 1913, the wheat price gap between Liverpool and Chicago fell from $57.6 \%$ to $15.6 \%$ and the London-

${ }^{25}$ Daudin, Morys and O’Rourke, (2008, p. 3). 
Cincinnati bacon price gap fell from $92.5 \%$ to $17.9 \%$. The same period also saw US-British price gaps for industrial goods such as cotton textiles, iron bars, pig iron and copper falling from $13.7 \%$ to $-3.6 \%, 75 \%$ to $20.6 \%, 85.2 \%$ to $19.3 \%$ and $32.7 \%$ to $-0.1 \%$ respectively. $^{26}$ Prices also converged between Europe and Asia, with the London-Rangoon rice price gap falling between $93 \%$ to $26 \%$, and the Liverpool-Bombay cotton price gap falling from $57 \%$ to $20 \%{ }^{27}$

International trade grew for a number of reasons. International freight rates declined steadily as a result of constant technical improvements and the growth in the usage of faster and more regular steamships, especially after the opening of the Suez Canal in 1869. However, as overland transport was much more expensive than water transport, the reduction of internal transport costs through the development of railways was crucial (refer Figure 3 below). As a percentage of the Chicago wheat price, the cost of shipping wheat to New York declined from 17.2\% to 5.5\%, while the cost of shipping it from New York to Liverpool fell from $11.6 \%$ to $4.7 \% .{ }^{28}$ Declining transport costs were particularly good for European workers. In an era where a large fraction of labourers' budgets was still spent on food, cheaper transport meant cheaper food, and thus higher real wages. What was bad for farmers was directly beneficial to urban workers. By and large this also helps explain why socialist parties tended to support free trade in Europe. ${ }^{29}$ British workers should have particularly benefitted from free trade since not only did it lower the price of food, but any negative impact on agricultural labour demand would

\footnotetext{
${ }^{26}$ O'Rourke and Williamson, (1994).

${ }^{27}$ Findlay and O'Rourke, (2007, pp. 404-405).

${ }^{28}$ Findlay and O'Rourke, (2007, p. 382).

29 Daudin, Morys and O'Rourke, (2008, p. 11).
} 
only have a small effect on the overall labour market, given agriculture's small share in overall employment there (just $22.6 \%$ in 1871 )..$^{30}$

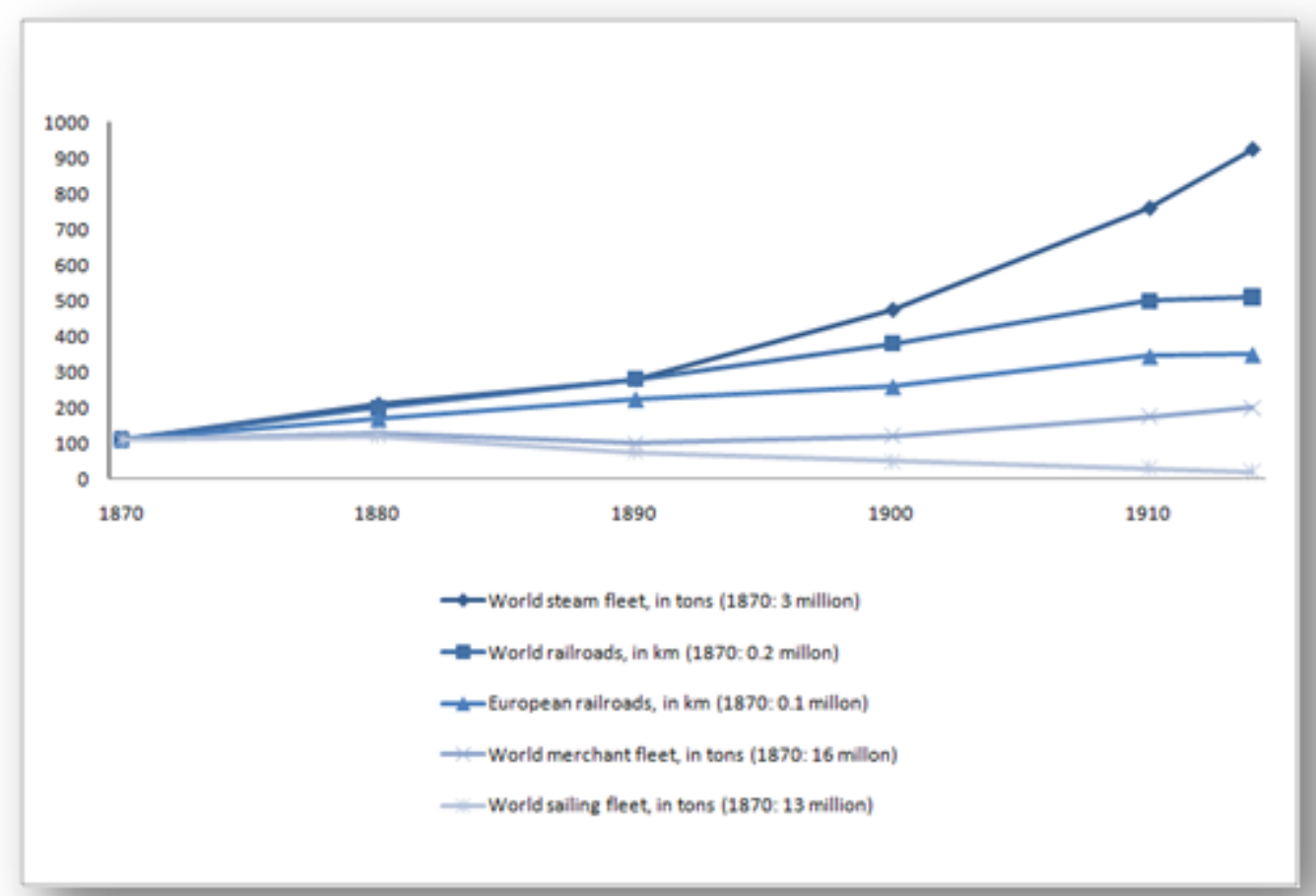

Figure 2: Transport infrastructure, 1870-1913

Another reason for trade growth at this time was freedom from hostilities. ${ }^{31}$ The development of European formal and informal empires increased extra-European trade through the reduction of trade barriers, the inclusion of colonies in currency unions, and

${ }^{30}$ Daudin, Morys and O’Rourke, (2008, p. 11).

31 Jacks, (2006). 
the better protection of European property rights. ${ }^{32}$ Meanwhile, the gradual spread of the gold standard dampened exchange rate fluctuations and reduced uncertainty in trade.

\subsubsection{The Multilateral Payments Network}

An important reason for the increasing economic integration between nations was the growth of a multilateral payments network and the facilitation role it played in trade. During the period from 1870 to 1913 , at least $20-25 \%$ of all trade transactions were multilateral. This encouraged international trade because countries could offset a trade deficit with one partner by a trade surplus with another. This in turn meant less gold and hard currency was needed for balanced trade, the scarcity of which often acted as an obstacle to international trade. Berend argues this system of multilateral payments was the catalyst for Europe's gradual move to a laissez-faire economic system. ${ }^{33}$ The crowning moment came with the introduction of the gold standard after 1870 . Until this time most European countries had a bimetallic (silver and gold) system (France), a silver standard (Holland, Scandinavia, the German states), or inconvertible paper money (Russia, Greece, Italy). Most currencies were not convertible, a major impediment to the expansion of foreign trade. The gradual adoption of the gold standard throughout Europe solved this problem. Reporting on the proposal to introduce the gold standard The Economist at the time had argued the benefits as being:

First, the losses resulting from exchanges would be greatly reduced, for the commission for exchange would represent only the cost of carrying specie from one country to another, and even the marvellous system of transfers by which bankers of London effected payments of 250,000,000F a day could be established between different countries; Second, an international money would render monetary crisis rarer, for the banks in the Confederate countries could more easily make

\footnotetext{
${ }^{32}$ Mitchener and Weidenmier, (2007).

${ }^{33}$ Berend, (2006, p. 13).
} 
payments in international coin than in ingots; Third, England would cease to suffer in her commerce from the fact that Belgians, Swiss and Italians prefer to make their purchase in countries in which they find the same moneys and measures as their own, instead of going to England, where exchange causes them loss and trouble. ${ }^{34}$

Each currency had a fixed gold content, and thus currencies became easily exchangeable and exchange rates stable. The British pound sterling, unchanged in value between 1821 and 1914, was practically as good as gold and became the international currency with the gradual transformation from protectionism and bimetallism toward free trade cum gold standard.

\subsubsection{Capital Flows, $1870-1914$}

The integration of capital markets is another indicator the world was becoming increasingly globalised. Europe at this time was the world's banker and those with good access to European capital and abundant resources, such as the US, Canada, Argentina and Australia, prospered most between 1870 and $1913 .{ }^{35}$ There was also a smaller, but still important, transfer of capital from the Western European core to the more peripheral economies of South, Central and Eastern Europe.

In their empirical analysis of European economic integration Craig and Fisher observed that during this period, financial capital expanded across borders in increasing volume, although not in any regular pattern. The most widely studied aspect has been the expansion of lending internationally, led by the United Kingdom, but all major countries were involved in both absorbing and exporting financial capital in this period, as individual investors seized on either local or international opportunities as they arose. ${ }^{36}$ The main

\footnotetext{
${ }^{34}$ Bagehot, Walter, (ed.), (9 April, 1870), “Foreign Correspondence," The Economist, pp. 448-449.

${ }^{35}$ Feis, (1930).

${ }^{36}$ Craig and Fisher, (1997, p. 202).
} 
characteristics of these capital flows were that, first, the largest volume of capital tended to flow to already-mature economies, and sectors, rather than relatively capital-poor countries, such as Spain and Portugal, and, second, all countries relied on their own savings pools for most of their capital needs. Even so, the pool of international lending was led by the United Kingdom, France and Germany with its expansion augmented by the arrival of US capital exports after $1890 .{ }^{37}$ Similarly, the destinations of these funds were other European countries, and the US, until after 1870, when India and the areas of white settlement around the world began to attract significantly more capital. Craig and Fisher also noticed that a sizeable portion of the capital involved went to governments rather than the private sector, 'although there are so many differences across countries and over time that generalizations beyond this are hard to produce. ${ }^{38}$

Successful capital formation also played a decisive role in helping determine the rate of absorption of the industrial revolution. Essentially this was a domestic matter, but the international pool of capital provided substantial assistance and was part of the conduit that also moved labour, products and technical ideas across borders.

Economists have drawn attention to the way capital market integration has traced out a U-shape over the past 150 years, ${ }^{39}$ with late nineteenth century integration being followed by interwar disintegration and a slow move towards reintegration in the late twentieth century. According to Obstfeld and Taylor, foreign assets accounted for $7 \%$ of world GDP in 1870 , but for nearly $20 \%$ during $1900-14$. The figure was only $8 \%$ in $1930,5 \%$ in 1945 , and still only $6 \%$ in 1960 . However, this rose dramatically to $25 \%$ in $1980,49 \%$ in 1990 , and $92 \%$ in 2000 . On this measure it was not until sometime in the 1970 s the pre1914 level of integration was recovered. Not that capital market integration was a

\footnotetext{
${ }^{37}$ Craig and Fisher, (1997, p. 203).

${ }^{38}$ Craig and Fisher, (1997, p. 203).

${ }^{39}$ Obstfeld and Taylor, (2004).
} 
continuous process. As is the case today, there were reversals, which subjected capitalreceiving countries to sudden stops. For example, a first wave of financial integration came to an end with the Baring crisis of 1890 and capital receded dramatically for about a decade before massive foreign lending resumed again around the turn of the century.

Feldstein and Horioka have suggested another measure of integration. ${ }^{40}$ International capital mobility breaks the link between domestic savings and domestic investment, as domestic savings can be invested abroad and domestic investment can be financed externally. Consequently, the weaker the relationship between domestic savings and domestic investment, the higher is international capital mobility. The U-shape once again emerges from the data. A third measure looks at bond spreads. Bond spreads between peripheral economies, be they in Europe or not, and England, France and Germany fell, on average from around 5\% in 1870 to only $1 \%$ in $1914 .{ }^{41}$ Maruo, Sussman and Yafeh have shown that emerging market bond spreads were, on average, less than half what they were in the 1990s, which demonstrates just how safe investors perceived foreign investment to be. ${ }^{42}$

In looking for explanations for late-nineteenth early-twentieth century capital market integration, Daudin, Morys and O'Rourke also suggest the absence of military conflict, when an atmosphere conducive to foreign lending was created and stabilised. ${ }^{43}$ Another political explanation, by contrast, has been highly controversial. Marxists have long argued that late nineteenth century capital exports and imperialism are only two sides of the same coin. Their argument is that excessive saving at home, generated by a highly unequal distribution of income, required outlets in underdeveloped countries, as

\footnotetext{
${ }^{40}$ Feldstein and Horioka, (1980).

${ }^{41}$ Flandreau and Zumer, (2004).

${ }^{42}$ Mauro, Sussmna and Yafeh (2002).

${ }^{43}$ Daudin, Morys and O'Rourke, (2008).
} 
domestic investment would have been subject to Marx's law of the falling rate of profit. This idea, associated with J. A. Hobson, allowed Lenin to declare imperialism to be the highest stage of capitalism. ${ }^{44}$ The argument of a connection between empire and capital exports has subsequently been discredited by some scholars, although some revisionist historians have argued for a more benign interpretation of imperialism. For example, Ferguson and Schularick, argue that members of the British Empire benefited from their colonial status through substantially reduced interest rates, presumably as a result of more secure property rights. ${ }^{45}$ However, Table 3 below raises doubts about whether colonial affiliation mattered for the size and direction of capital flows. All English colonies combined, excluding Canada, Australia and New Zealand, received only 16.9\% of English capital exports, which is less than what the US alone received (20.5\%). The French and German experiences suggest the same, with colonies receiving only $8.9 \%$ and $2.6 \%$, respectively, of the overall capital exports from their respective mother countries.

Some of the benefits of the gold standard have been highlighted and Daudin et al. point out an additional benefit. This was global financial integration, which was fostered by adherence to the gold standard because it signalled that governments concerned would pursue conservative fiscal and monetary policies and assured potential investors that returns were reasonably safe. ${ }^{46}$ However, while economic institutions can facilitate capital imports, they can never attract them if there is no genuine interest on the part of investors in what a specific country has to offer. Daudin et al. argue this places a focus on economic fundamentals as the main determinant in explaining the size and direction of flows. ${ }^{47}$ Over $50 \%$ of British capital exports went to areas of recent settlement (refer Table

\footnotetext{
${ }^{44}$ Hobson, (1902:1988).

${ }^{45}$ Ferguson and Schularick, (2006).

${ }^{46}$ Daudin, Morys and O’Rourke, (2008, p. 6).

${ }^{47}$ Daudin, Morys and O’Rourke, (2008, p. 6).
} 
3 below) where natural resources could be exploited, not to where labour was cheap (Africa and Asia). If New World land was to produce food for European consumers, and raw materials for factories, railways had to make it accessible, land had to be improved, and housing and infrastructure had to be provided for the new frontier communities. Clemens and Williamson provide econometric evidence in favour of this view, showing British capital exports went to countries with abundant supplies of natural resources, immigrants, and young, educated, urban populations. ${ }^{48}$ While foreign investment in Africa and Asia was rather unpopular in Britain, France and Germany, France and Germany sent $6.1 \%$ and $53.3 \%$ respectively, of their capital exports to other European countries. Investment in areas of recent settlement by contrast, played a substantially reduced role for both countries.

${ }^{48}$ Clemens and Williamson, (2004). 
Table 3: Destination of English, French and German Foreign Investment

\begin{tabular}{|c|c|c|c|}
\hline & England & France & Germany \\
\hline \multicolumn{4}{|l|}{ Europe } \\
\hline Russia & $3.4 \%$ & 25.196 & $7.7 \%$ \\
\hline Ottoman Empire & $1.0 \% 6$ & 7.396 & 7.796 \\
\hline Austria-Hungary & $1.0 \%$ & $4.9 \%$ & $12.8 \%$ \\
\hline Spain and Portugal & $80.0 \%$ & $8.7 \%$ & 7.296 \\
\hline Italy & $1.0 \%$ & $2.9 \%$ & \multirow{2}{*}{17.9} \\
\hline Other Countries & $2.5 \%$ & 12.296 & \\
\hline Total (Europe) & $9.7 \%$ & 61.196 & $53.3 \%$ \\
\hline \multicolumn{4}{|l|}{ Areas of recent settlement } \\
\hline USA & $20.5 \%$ & \multirow{3}{*}{4.496} & \multirow{2}{*}{$15.7 \%$} \\
\hline Canada & $10.1 \%$ & & \\
\hline Australia & $8.3 \%$ & & \\
\hline New Zealand & $2.1 \%$ & & \\
\hline Total & $41.0 \%$ & $4.4 \%$ & $15.7 \%$ \\
\hline \multicolumn{4}{|l|}{ Latin America } \\
\hline Argentina & $8.6 \%$ & \multirow{8}{*}{$13.3 \%$} & \multirow{8}{*}{$16.2 \%$} \\
\hline Brazil & $4.2 \%$ & & \\
\hline Total (areas of recent settiment) & $53.8 \%$ & & \\
\hline \multicolumn{2}{|l|}{ Other countries } & & \\
\hline Mexico & $2.0 \%$ & & \\
\hline Chile & $1.5 \%$ & & \\
\hline Uruguay & $0.8 \%$ & & \\
\hline Cuba & $0.6 \%$ & & \\
\hline Total (Latin America) & $17.7 \%$ & $13.3 \%$ & $16.2 \%$ \\
\hline Africa & $9.1 \%$ & $7.3 \%$ & 8.596 \\
\hline \multicolumn{4}{|l|}{ Asia } \\
\hline India & 7.896 & \multirow{3}{*}{$4.9 \%$} & \multirow{3}{*}{$4.3 \%$} \\
\hline Japan & $1.9 \%$ & & \\
\hline China & $1.8 \%$ & & \\
\hline Total (Asia) & $11.5 \%$ & $4.9 \%$ & $4.3 \%$ \\
\hline Rest & $11.0 \%$ & $9.0 \%$ & $2.0 \% 6$ \\
\hline Total & 100.056 & $100.0 \%$ & $100.0 \%$ \\
\hline Colonies & $16.9 \%$ & $8.9 \%$ & $2.6 \%$ \\
\hline
\end{tabular}

Notes: Numbers for Russia and the Ottomon Empire include Asia. "Colonies" does not include Australia, Canada or New Zealand

Sources: Esteves (2007), Feis (1930), Stone (1999) 


\subsubsection{Migration, $1870-1914$}

Williamson argues that the forces of convergence leading to globalisation were due to open economic policies of free trade and mass migration. ${ }^{49}$ Daudin et al. also argue 'it is in the area of migration that the late nineteenth century was most impressively globalised, even compared to today. ${ }^{50}$ Table 4 below gives an indication of just how large migration was for European nations. The figures given are gross, not net, and the extent of return migration varied over time and across countries, rising from about $10 \%$ of the outflow initially to around $30 \%$ at the turn of the century. ${ }^{51}$ For example, while return migration was significant among Italians and Greeks it was very low among other groups, such as the Irish and Eastern European Jews. In addition to these transoceanic migrations, there were significant migrations within Europe, for example from Italy to France, and from Ireland to Britain. The average Western European annual outmigration rate was 2.2 per thousand in the 1870 s and 5.4 per thousand for the $1900 \mathrm{~s}^{52}$

\footnotetext{
${ }^{49}$ Williamson, (1996, p. 278).

${ }^{50}$ Daudin, Morys and O’Rourke, (2008, p. 6).

${ }^{51}$ Chiswick and Hatton, (2003, p. 70).

${ }^{52}$ Hatton and Williamson, (2005, p. 261).
} 
Table 4: European Emigration Rates by Decade (per 1000 mean population)

\begin{tabular}{|c|c|c|c|c|c|c|}
\hline Country & $1851-60$ & $1861-70$ & $1871-80$ & $1881-90$ & $1891-00$ & $1901-10$ \\
\hline \multicolumn{7}{|c|}{ European Emigration Rates } \\
\hline Austria-Hungary & & & 2.9 & 10.6 & 16.1 & 47.6 \\
\hline Belgium & & & & 8.6 & 3.5 & 6.1 \\
\hline British Isles & 58.0 & 51.8 & 50.4 & 70.2 & 43.8 & 65.3 \\
\hline Denmark & & & 20.6 & 39.4 & 22.3 & 28.2 \\
\hline Finland & & & & 13.2 & 23.2 & 54.5 \\
\hline France & 1.1 & 1.2 & 1.5 & 3.1 & 1.3 & 1.4 \\
\hline Germnay & & & 14.7 & 28.7 & 10.1 & 4.5 \\
\hline Ireland & & & 66.1 & 141.7 & 88.5 & 69.8 \\
\hline Italy & & & 10.5 & 33.6 & 50.2 & 107.7 \\
\hline Netherland & 5.0 & 5.9 & 4.6 & 12.3 & 5.0 & 5.1 \\
\hline Norway & 24.2 & 57.6 & 47.3 & 95.2 & 44.9 & 83.3 \\
\hline Portugal & & 19.0 & 28.9 & 38.0 & 50.8 & 56.9 \\
\hline Spain & & & & 36.2 & 43.8 & 56.6 \\
\hline Sweden & 4.6 & 30.5 & 23.5 & 70.1 & 41.2 & 42.0 \\
\hline Switzerland & & & 13.0 & 32.0 & 14.1 & 13.9 \\
\hline
\end{tabular}

The causes of this mass migration are more clearly understood than they were when Dudley Baines examined European emigration for the period 1815-1930. Over these 115 years more than 50 million people left Europe for other destinations. In his study Baines made the point, 'we have little reliable direct evidence of what is presumably the most important question. ... why did people emigrate ... and why did only some Europeans choose to emigrate and not others?'53 Daudin et al. on the other hand, argue, 'the causes .. are by now well understood. ${ }^{54}$ On one level, the causes were obvious. The New World was endowed with a higher land-labour ratio than Europe, and earned higher wages than their European counterparts. British real wages in 1870 were less than $60 \%$ of wages in

\footnotetext{
${ }^{53}$ Baines, (1994, p. 525).

${ }^{54}$ Daudin, Morys and O’Rourke (2008, p. 7) from Hatton and Williamson (1998, 2005).
} 
New World destinations relevant to British workers and for Irish workers $44 \% .{ }^{55}$ The gains from migration were significant and once the new steam technologies had lowered the cost of travel sufficiently, mass emigration became inevitable. Assisting this process were liberal immigration policies.

One issue difficult to explain is what determined the timing of emigration streams from different countries. For example, why did emigration from relatively rich countries such as Britain take off before emigration from poorer countries such as Italy, where gains to migrants were presumably higher? What explains the fact that so few French emigrated, while so many Irish and Italians left? What explains the initial rise, and subsequent decline, of emigration rates in several countries? Based on Hatton and Williamson's research, they found explanations for migration, although these more difficult questions are harder to address. ${ }^{56}$ This notwithstanding, Hatton and Williamson found that first, would-be emigrants were initially constrained by trans-oceanic transport, but as transport costs fell, more migrants were able to leave their homelands. Second, once previous emigrants were settled they sent remittances or pre-paid tickets back home, thus directly financing the cost of travel. Third, fertility rates were on the rise in Europe during this time, which led to an increase in the supply of young, mobile males. Finally, the process of industrialisation increasingly detached workers from the land, which increased mobility.

Of all the impacts from globalisation, migration was the one that had the greatest impact on European workers' living standards. For example, between 1870 and 1910 emigration lowered the labour force by $45 \%$ in Ireland, by $39 \%$ in Italy, and by $24 \%$ in Norway. ${ }^{57}$ During this same period living standards in all three economies rose more

\footnotetext{
${ }^{55}$ Hatton and Williamson, (2005, p. 55).

${ }^{56}$ Hatton and Williamson, (1998).

${ }^{57}$ O’Rourke and Williamson, (1999, Table 8.1).
} 
rapidly than in Britain. In Ireland wages rose from $73 \%$ to $92 \%$ of the British level, while Norwegian wages rose from $48 \%$ and $95 \%$. In Italy there was no convergence until the turn of the century, which is when Italian emigration exploded and thereafter real Italian wages rose from $40 \%$ of British wages in 1900 to $56 \%$ in 1913.

\subsubsection{Trade in knowledge}

Economic globalisation involves more than the movement of goods or factors of production. Technological transfers and the deepening of other intellectual exchanges are just as important in the process. Technology diffusion encountered few constraints in the late nineteenth century. Textile mills around the world used similar machines, often imported from Britain. ${ }^{58}$ Shipbuilding, iron and steel, telegraph and telephone technologies transferred quickly. Europe was internally exchanging new technologies, diffusing them both to European offshoots and to the rest of the world, and receiving new technologies, mainly from the United States. Daudin et al. argue that several new factors increased the speed and the reach of technological transfers. ${ }^{59}$ First migration was easy. Second imperialism allowed entrepreneurs to invest overseas, taking advantage of low wages, with no fear of expropriation by hostile governments. Third the decline in transport and communication costs helped the diffusion of ideas, new goods and machines. This last effect was important because more and more technology was embedded in machines rather than individual know-how, even if training was still necessary. Firms could now export capital goods on a large scale.

This diffusion of technologies was also helped by the creation of international scientific and technical organisations. For example, "The Institution of Naval Architects" was founded in 1860 in the United Kingdom, but organised meetings in different countries and through its membership created an international network of professional and learned

\footnotetext{
${ }^{58}$ Clark, (1987).

59 Daudin, Morys and O'Rourke, (2008, p. 8).
} 
bodies. ${ }^{60}$ As Figure 4 below shows, the number of scientific conferences and organisations increased dramatically. Paradoxically, science was also seen as one of the weapons in the struggle between European nations. Besides military applications, academic activity was used as a diplomatic weapon. Inviting foreign scientists and participating in scientific congresses was part and parcel of the rivalry between France and Germany, as each hoped to tighten their links with Allied and neutral countries, especially the United States. $^{61}$

${ }^{60}$ Ville, (1991).

${ }^{61}$ Charle, (1994, Ch. 8). 


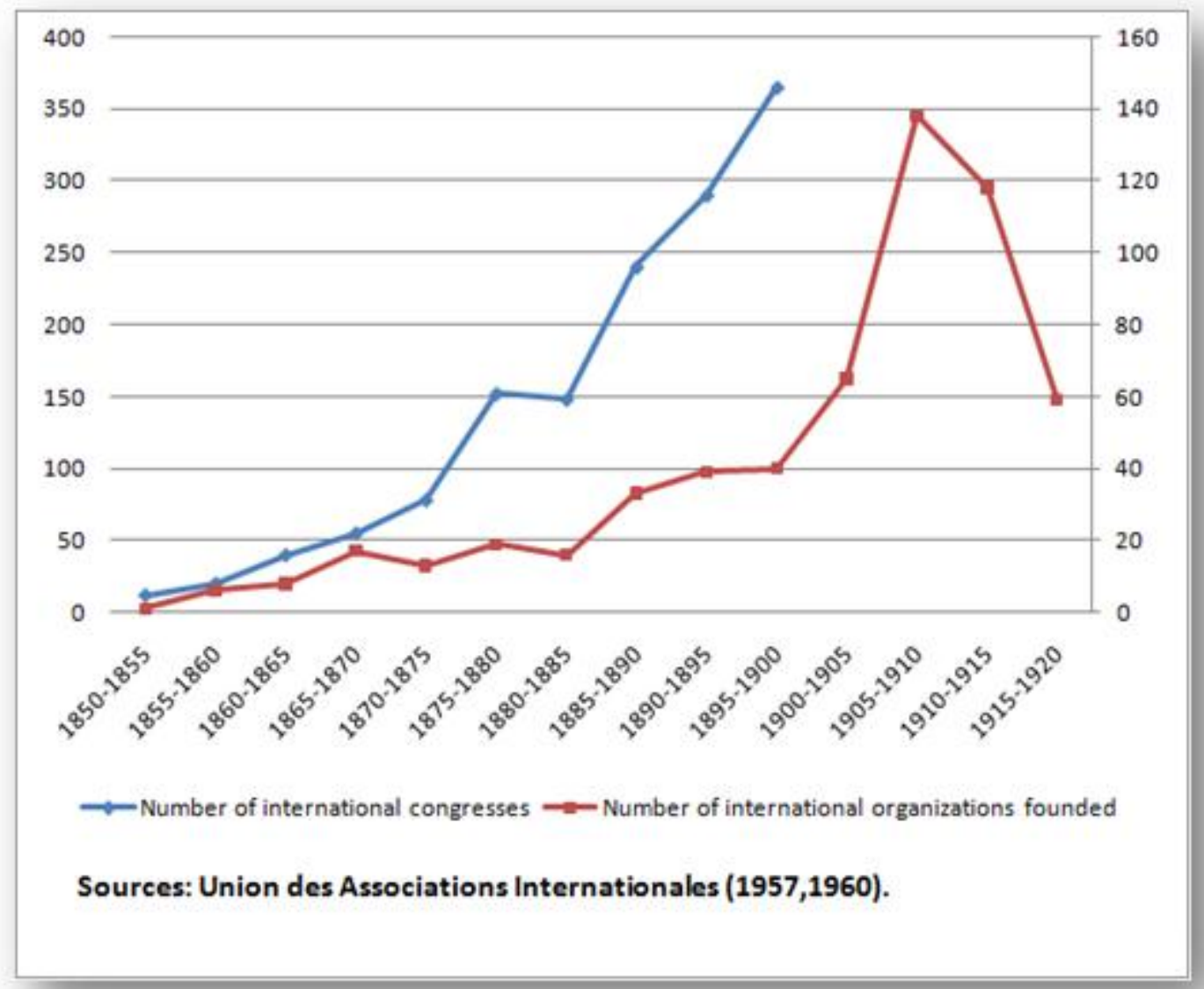

Figure 3: The rise of the international scientific community 


\subsubsection{Laissez-Faire}

Some economists, seeking to distinguish the period 1870 to 1913 from present day globalisation, argue that the earlier period was the 'golden era' of international integration, due to the greater openness of the world economy. ${ }^{62}$ Those who accept this view attribute this openness to the principle of laissez-faire. The maxim 'laissez-faire' is commonly attributed to Vincent de Gournay (1712-1759) although it was perhaps most clearly stated by the Marquis d'Argenson in $1858 .{ }^{63}$ To govern better, he stated, one must govern less. Adam Smith was a proponent of the laissez-faire principle and he believed the wealth of a nation could be increased if the market was free from constraints and Government intervention was kept to a minimum. He applied the same principle to the relationship between the Government and the individual and he used it to justify individualism and self-help. His ideological heirs include Thomas Malthus, Edmund Burke, David Ricardo, Harriet Martineau and Jeremy Bentham.

In his A Manual of Political Economy (1793) Bentham formulated the law: "The general rule is that nothing ought to be done or attempted by government." By the eve of World War One the laissez-faire economic system held unchallenged domination throughout Europe. Berend argues, 'under the banner of laissez-faire ideology, internationalisation, or the first globalizing trend of the European economy, made great progress and became institutionalized.' ${ }^{64}$ The rapid spread of free trade and the gold standard created a no- or low-tariff zone in Europe and a convertible currency with extremely stable exchange rates during the entire period. Material progress and improvements followed and gathered pace. On 31 December, 1910 The Economist commented on the system of laissez-faire:

\footnotetext{
${ }^{62}$ Nayar, (2003, p. 4777).

${ }^{63}$ Backhouse and Medema, (2008).

${ }^{64}$ Berend, (2006, pp. 13-15).
} 
The trade boom is still with us, and 1911 should bring few distractions to prevent the country from receiving the full benefit of its later stages. The prospect tempts us to break our resolution, and to utter one prophecy in the style of the almanacs. It is - "In 1911 the expression laissez-faire will be less used by politicians and business men as a term of economical abuse than formerly." Realising the blessings of freedom from disturbance, the commercial world may well begin to wonder why it should be asked to subject itself to the greatest of all disturbances, the convulsions of a season of tariffmongering. The trade returns are encouraging it to proclaim (what it always believes at bottom) that business men know best about their own businesses, and that the State, if it meddles with them, is sure to make a mess of it. The interpretation of our prophecy is, therefore, that with prosperous times the conviction will grow that trades are best left free to be conducted by those who understand them, without interference, however well meant, by those who do not. ${ }^{65}$

The system of laissez-faire The Economist credited as responsible for European prosperity was, however, an uneven and often unstable system. In relation to the rest of the world, Europe, at the turn of the twentieth century, was dominant in the world economy, representing nearly half (46\%) of the world's total GDP. However, from the 1870 s onward other countries emerged as competitors. During the nineteenth century, taken together, the United States, Canada, Australia, and New Zealand increased their GDP by 43 times, reaching 79\% of the total West European GDP level by 1913. Taken on a per capita basis the picture is somewhat different. In 1820 and 1870, these countries were far behind Britain and Western Europe, reaching only $69 \%$ and $75 \%$ of its per capita income level respectively, but by the 1870 s they broke through and by 1913 they already surpassed Britain by $4 \%$ and Western Europe in general by more than $40 \% .{ }^{66}$

\footnotetext{
${ }^{65}$ Hirst, Francis Wrigley, (ed.), (31 December, 1910), “The Coming Year,” The Economist, p. 1324.

${ }^{66}$ Berend, (2006, p. 22).
} 
Yet Europe in 1913 still dominated the world of industry, producing $52 \%$ of the world's industrial output. Three European countries, Britain, Germany, and France, produced $72 \%$ of all European manufactured products. The same three countries bought $63 \%$ of the world's food and raw material exports and accounted for $62 \%$ of world trade in 1913. Europe also became the world's banker by exporting more than \$US 40 billion, roughly $90 \%$ of total international capital exports, during the nineteenth century. ${ }^{67}$ But while the world economy was effectively a European world economy, the economic system was strongly internationalised and while co-operation was essential for this to be sustained, the most powerful players of industrialised Europe became competitive, and at times, hostile rivals for world leadership. During the last third of the nineteenth century the core countries of Western Europe embarked on a quest for empire, leaving few nations of the world without some form of government. Britain alone built an empire of 345 million people while France controlled 56 million in Africa, Asia, and the Pacific region. This expansionism was controversial at the time, and remains so to the present day. Colonialism, or "imperialism," as Hobson's book of 1902 named the phenomenon, 'gained a new incentive from industrial capitalism. ${ }^{68}$ Empire building was closely connected with the rapid advance of capitalist economies with strong economic motivations, and also became a major status symbol for the great powers. For example, in the case of Germany Lebensraum, or "struggle for space" became an ideological base for expansionism. As a political phenomenon, however, imperialism did not necessarily equate to economic prosperity, as many colonies were to prove unprofitable.

This added to a picture of growing inequalities and disparities that began to undermine the almost century-long unbroken phase of economic development since the high levels of prosperity unleashed by the industrial revolution. Keynes, writing in 1919, described the previous fifty years:

\footnotetext{
${ }^{67}$ Berend, (2006, p. 22).

${ }^{68}$ Hobson, (1902:1988).
} 
Very few of us realise with conviction the intensely unusual, unstable, complicated, unreliable, temporary nature of the economic organisation by which Western Europe has lived for the last half century. We assume some of the most peculiar and temporary of our late advantages as natural, permanent, and to be depended on, and we lay our plans accordingly. On this sandy and false foundation we scheme for social improvement and dress our political platforms, pursue our animosities and particular ambitions, and feel ourselves with enough margin in hand to foster, not assuage, civil conflict in the European family. Moved by insane delusion and reckless self-regard, the German people overturned the foundations on which we all lived and built. ${ }^{69}$

In reality, while laissez-faire policies had meant spectacular economic growth and unprecedented rates of industrialisation for most of Western Europe, such was not the case for most of the countries of Southern and Eastern Europe. Berend argues, 'globalised laissez-faire did not live up to its promise in some of the peripheral countries of Europe, and it faced increasing challenges. State interventionism gained ground. ${ }^{70}$

In summarising pre-war Europe, a process of globalisation from 1870 to 1913 had brought into existence an integrated and interdependent European economy. On all significant measures - trade, financial systems and a multilateral payments networks underpinned by the gold standard, capital flows, migration, trade in knowledge, and the impact of laissez-faire capitalism - European living standards and economic development grew in ways not before seen in human history. During this period Europe also helped spread the benefits of industrialisation and globalisation to many other nations around the world. Europe and the rest of the world stood to gain nothing by engaging in warfare. Yet on the very eve of this economic achievement and development, a war between European nations broke out and quickly spread to all developed countries. In seeking

\footnotetext{
${ }^{69}$ Keynes, (1919, p. 1).

${ }^{70}$ Berend, (2006, p. 40).
} 
explanations for this mutual economic self-destruction, most economists have concluded that the same forces of globalisation, which had delivered prosperity and stability also nurtured the seeds of divergence. As weaker nations failed to share in Europe's economic prosperity and a spirit of nationalism increased, competitive jealousies and protectionist policies fanned the flames of growing discontent. 


\subsection{Economics and World War One}

According to some commentators World War One was the result of intensified protectionism leading to the breakdown of the laissez-faire trading system, which was a natural consequence of exalted nationalism that equated self-defence and independence with economic self-sufficiency. ${ }^{71}$ Broadberry and Harrison, on the other hand argue that the breakdown of the system of laissez-faire is too narrow an explanation for the cause of war. Instead they argue it was the process of globalisation, which ultimately led to World War One. However, while the process was global, the European dimension was fundamental to it. The war was fought primarily by European powers in Europe while some non-European participants and colonial polities played a minor role and yet others, such as the US, intervened late in the process. ${ }^{72}$ Nonetheless, this process had unleashed a number of forces, both political and economic, with colonial ambitions at its heart. Eloranta and Harrison argue that 'nineteenth century globalization and empires were inextricably linked. ${ }^{73}$ At first sight it seems competition for colonies was a primary reason for European nations going to war as each country's imperial ambitions ran out of control. Broadberry and Harrison argue, European powers did not fight World War One over colonies but rather war was a reaction to Germany's desire for colonies. This stimulated a naval arms race. They also argue it was the quest for a German empire [that] provoked an anti-German coalition, the Entente Cordiale between Britain and France (1904) to which Russia was also admitted in $1907 .{ }^{, 74}$ Germany had allies of course and had been a friend of Russia since 1872, Austria-Hungary since 1879, and Italy since 1882, but Russia and Germany had drifted apart and Italy would be an unreliable ally. The increasing

\footnotetext{
${ }^{71}$ Berend, (2006, p. 47).

${ }^{72}$ Eloranta and Harrison, (2010, p. 134).

${ }^{73}$ Eloranta and Harrison, (2010, p. 136).

${ }^{74}$ Broadberry and Harrison, (2005, p. 3).
} 
polarisation of the continental powers shifted attention away from Germany's original aim, which was for 'an adjustment of the boundaries of the British and French empires overseas, towards the balance of power in Europe itself. As a result, the war was largely fought on European soil for the control of Europe. ${ }^{75}$ When war did break out, it was not envisaged economic reasons were that important to an eventual outcome. For example, the German war plan for 1914 anticipated victory in the west within six weeks. As such it was intended to be a war by military means. However, as time went on economic factors became significant determinants of who were winners and losers. A report carried in The Times on March 27, 1915 highlighted this realisation early in hostilities. In an interview with a "neutral" journalist of two prominent Germans, Herr Witting, a director of the Reichsbank and Herr Zimmermann, Secretary of State for Foreign Affairs, Herr Witting commented, 'we are certainly not making war as we did in 1870 . We have met with serious difficulties, even suffered reverses, and our idea of finishing the war in a few months was a mistake ... this war is a war of exhaustion. ${ }^{, 76}$

As this sense of exhaustion affected morale and economies the war developed into one of attrition with the large, rich economies of Germany, France and Britain grinding each other down with resources counting for almost everything. It was the greater Allied capacity for taking risks, absorbing the cost of mistakes, replacing losses, and accumulating overwhelming quantitative superiority that eventually turned the tide against Germany. In the east where the economically weaker powers, Russia, Italy and the Austro-Hungarian and Ottoman empires faced off in battles, outcomes, at least in the short run, were determined less by economic factors. However, over a period of years battles drained the weakest economies first. This was the primary factor leading to Russia's exit from the war in 1917. But at the same time Russia abandoned the Allies the

\footnotetext{
${ }^{75}$ Broadberry and Harrison, (2005, p. 4).

${ }^{76}$ Dawson, George Geoffrey, (ed.), (27 March, 1915), "German Change of Tone: A War of Exhaustion," The Times, p. 8.
} 
United States entered the conflict. Thus the richest world power stepped into the gap left by the poorest, and this led to a further increase in the Allied advantage. Then, the Central Powers' chance for victory in the east was destroyed by Germany's defeat in the west. Ultimately, economics determined the outcome.

Notwithstanding Singleton's observation that 'enough evidence has been presented to show that the individual cost of the First World War is beyond calculation,' it is possible to compare and contrast the statistics we do have, although many need to be treated with caution. ${ }^{77}$ Broadberry and Harrison undertake an analysis by adding up populations, territories, and gross domestic products from territories at war. Comparing population, territory and GDP between the Allies and the Central Powers in November 1914 and again in November 1918 the following picture emerges: In November 1914 the Allies had a collective population ratio of 5.2 times greater than the Central Powers, that is Allies 793.3 million vs Central Powers 151.3 million, the Allies covered a territory 11.5 times greater than the Central Powers and GDP 2.9 times greater than the Central Powers. In November 1918 the population was 8.1 times greater, covering territory 13.5 times greater and GDP 4.6 times greater. ${ }^{78}$ The wartime change in GDP is given in Table Five below. These figures show the economic advantage had moved even further in the Allies favour by the end of the war.

\footnotetext{
${ }^{77}$ Singleton, (2007, p. 14). Singleton is not referring to the objective nature of statistical comparisons but refers rather to the impact on individuals where, as he states, it is impossible to attach money values to the utility or cost of war in the minds of men, women and children who experience war.

${ }^{78}$ Broadberry and Harrison, (2005, p. 11). Currency units are international dollars at 1990 prices.
} 
Table 5: The wartime change in real GDP: 1914-1918, by country

\begin{tabular}{|c|c|c|c|c|c|c|}
\hline & UK & USA & Germany & Austria & Russia & France \\
\hline 1913 & 100.0 & 100.0 & 100.0 & 100.0 & 100.0 & 100.0 \\
\hline 1914 & 92.3 & 101.0 & 85.2 & 83.5 & 94.5 & 92.9 \\
\hline 1915 & 94.9 & 109.1 & 80.9 & 77.4 & 95.5 & 91.0 \\
\hline 1916 & 108.0 & 111.5 & 81.7 & 76.5 & 79.8 & 95.6 \\
\hline 1917 & 105.3 & 112.5 & 81.8 & 74.8 & 67.7 & 81.0 \\
\hline 1918 & 114.8 & 113.2 & 81.8 & 73.3 & & 63.9 \\
\hline
\end{tabular}

Source : Maddison (1995: 148-51), except Russia from Gatrell (this volume, table 8.2). Italy is omitted for reasons given in the appendix to chapter 9 .

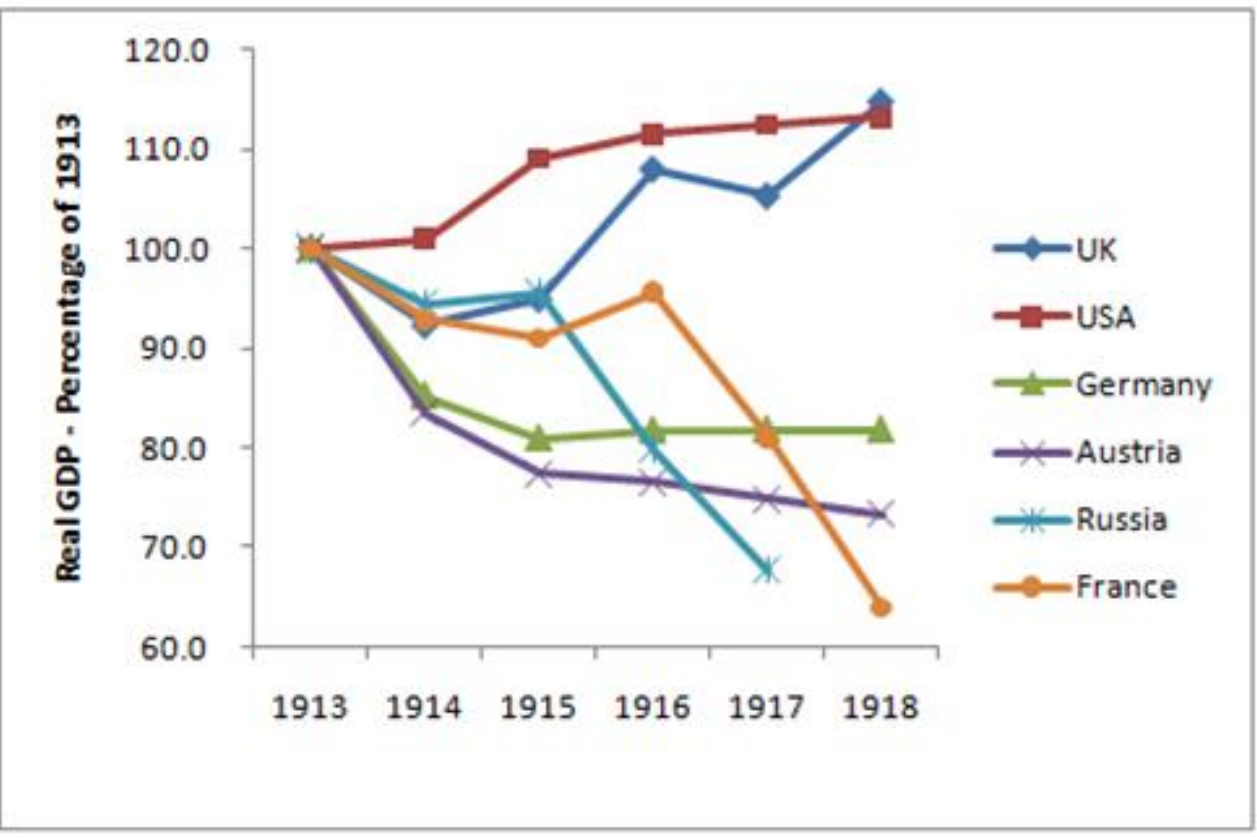

Behind these figures are the reasons why population, territory, and GDP mattered. Greater population numbers translated into more human resources available for the war Page 159 
effort. Territory is an important economic measure with limited breadth and variety of natural resources available for agriculture and mining important for total capability. The wider the territory, the more varied were the soil types and the minerals beneath the soil so that quantity in this case also meant quality. As for the GDPs of countries at war, economic capacity limited the volume of weapons, machinery, fuel, and rations that could be made available to arm and feed the soldiers and sailors on the fighting front. In short, the larger the population, territory, and GDP of a country, the easier it would be for that country to overwhelm the armed forces of an adversary. ${ }^{79}$

Critics of an economic approach to analysing war argue there are many contingent factors, for example, moral, political, technical, and organisational, that outweigh economic explanations. For example, Singleton argues,

the First World War was an economic disaster of the highest order, especially in Europe. The greatest impact was felt at the level of the individual - millions were killed or wounded and others lost relatives, wealth and incomes. While it is not possible to put a dollar figure on the 'cost' of the war, it begs the question; what is the point of bothering with economic explanations? ${ }^{80}$

Because, argue Broadberry and Harrison, 'other things being held equal, a deficit of organisation or morale on one side tended to be overcome through a self-balancing process. The one thing that could not be overcome was a deficit of resources. ${ }^{81}$ Two examples, both German offensives (August 1914 and March 1918), that gave Germany its best chances of winning the war, support this view. In the first of these attacks (1914) Germany planned to exploit mass and movement to destroy the French army before the British could intervene in the west and before the Russians could mobilise in the east. In

\footnotetext{
${ }^{79}$ Broadberry and Harrison, (2005, p.11).

${ }^{80}$ Singleton, (2007, p. 42).

${ }^{81}$ Broadberry and Harrison, (2005, p. 13).
} 
practice the German army succeeded in many of its planned objectives but failed in the ones that were vital. The stalemate of the trenches resulted. Had the German plan succeeded, the economic factors on each side would never have been felt. Given that it did not, the richer Allies won time to put right their military and organisational failings, but they could not have done so without resources on their side.

In the second example, the spring offensive in 1918, Germany again seemed to be on the verge of winning with a purely military advantage. For the first time since 1914 its soldiers opened up great gaps in the Allied lines and advanced dozens of kilometres towards the Channel ports. The offensive badly shocked the Allies and forced them into re-organisation with the Americans, resulting in the acceptance of a unified command. But resources ultimately defeated the advancing Germans: their own supplies were lacking for they were badly clothed and undernourished even before they began their advance; the abundance of supplies they found in the Allied trenches caused many to turn away from the attack to eat and drink their advantages away; and the superabundance of war materials that enabled the Allies to regroup and go on to inflict a far greater defeat on the exhausted enemy - all contributed to the German defeat.

Other economic factors played their part. For example, those countries most advanced in the economics of agriculture enjoyed relatively greater success on the battlefield. This helps explain why countries like Russia and Austria-Hungary, while large, could not make a difference. With the exception of Russia, these countries ran short of food long before they ran out of guns and shells. Russia's difficulties lay in the chaotic transportation system rather than food shortages per se. In the case of Germany, her decline in agricultural output during the war and lack of access to food imports is a further explanation for her ultimate loss due to economic reasons. Also against Germany was modernisation, which was highly unbalanced even though Germany was considered a developed economic power. Broadberry and Harrison argue, 'high levels of productivity in 
heavy industry co-existed with much lower productivity in light industry, and much of the service sector was also characterised by low productivity. ${ }^{82}$ However, the most obvious sign of Germany's relative backwardness was the high share of the labour force engaged in low-productivity agriculture. When war broke out Germany suffered the consequences of its reliance on peasant agriculture and it was essentially a dead weight on her mobilisation efforts with the result that 'the process resulted in the inexorable conclusion [of] urban famine, revolutionary insurrection, and the downfall of emperors. ${ }^{83}$

In summary, economic advantage, especially over time, made the difference to the final outcome of World War One. At the start of hostilities the Allies had a relative advantage in population, territory and GDP. By the end of the war the relative gap had widened further, giving the Allies an economic advantage that ultimately meant victory. The difference economic advantage played in World War One becomes even more significant when making comparisons with World War Two. For some World War Two was just World War One with more countries, more soldiers, more time, more money, more guns, more death and more destruction. In reality, argue Broadberry and Harrison, World War One had some distinctive features. For example, economics decided the outcome of the first war in a direct and straightforward sense, more so than in the second. The military decision of World War One was expected on the western front, where the richest countries engaged most of their forces. Yet the military decision never came. While it is true there were victories and defeats, and the front became considerably less stable during 1918, military struggle ended in ceasefire, not surrender, with the German army still standing on foreign soil. In Austria-Hungary it was also economic collapse that ended the military aspirations of the Hapsburgs, just as urban famine and industrial collapse in Russia signed the death warrant of the Romanovs. Where the outcome of World War Two was different was that it ended in crushing military defeat of the Axis Powers.

\footnotetext{
${ }^{82}$ Broadberry and Harrison, (2005, p. 21).

${ }^{83}$ Broadberry and Harrison, (2005, p. 22).
} 
From an economic perspective, the period between 1914 and 1945 is distinctive. In both wars the combatants were able to devote more than half their national income to the war effort. This did not happen before 1914, or after 1945, and it seems unlikely to ever happen again. Before 1914 it was impossible and after 1945 it is no longer necessary. Before the twentieth century, per capita incomes were too low and government services too inefficient for society to devote such a large share of economic activity to warfare. Too many people were required to labour in the fields and workshops simply to feed and clothe the population, and government officials were not up to the task of counting and controlling them. After 1945 the destructive power of nuclear weapons meant any rich or large country could acquire devastating military capability for a few billion dollars. Hence the marshalling of economic resources played a much more vital role in the outcome of the two world wars than any period before or since. This is why scholars such as Broadberry and Harrison maintain the history of World War One cannot be written without the economics. ${ }^{84}$

The war also left an economic legacy, which had to be addressed urgently and helps explain why Keynes was so adamant Europe's problems were primarily economic ones. Europe had been transformed as a result of the deprivations visited on all sectors of all societies, in addition to which there was the physical destruction of land and capital. Damage, however, extended well beyond pure economic destruction. There was the emotional, psychological and social damage inflicted on many individuals, both combatants and civilians, from all countries caught up in the conflict. As a result Europe emerged from war weak, divided and unstable. Following hostilities the convergent processes of globalisation that had brought prosperity to many before 1914 now veered more and more toward patterns of divergence as leaders and politicians looked for ways of returning Europe to the relative stability Europeans had enjoyed before the onset of war.

${ }^{84}$ Broadberry and Harrison, (2005, p. 36). 


\subsection{The European Economy Post-World War One}

Looking back on just over a year of peace The Economist cautioned that

with regard to the situation abroad, the best that can be said is that it is so serious that it is beginning to attract attention. Prostrate Europe cannot recover without help, and the great difficulty to be solved by the countries that can give help is how to see that it gets into the right hands. $^{85}$

Keynes was one of those who sought to 'attract attention' and he did so through his written works and practical involvement with groups such as the Economic Subcommittee of the Fight the Famine Fund, which he joined in July $1919 .{ }^{86} \mathrm{He}$, along with many of his contemporaries, recognised post-war Europe was a vastly changed place from pre-war Europe. Pre-war security had given way to disorder. The fear of extremism, including the Bolshevik revolution in Russia, was great in many countries. The war had destroyed an old order, and a new one was yet to be built, or to grow naturally. There had been a decisive shift of economic power from Britain to the US, though Britain retained significant power. But the transfer was not smooth. Many Americans feared plans, including Keynes' for the forgiveness of wartime indebtedness, would relieve Britain of responsibilities they should carry. Britain in turn feared US leadership would exploit its growing power and was uneasy about their growing dependence on America. ${ }^{87}$

\subsubsection{Social and Cultural Impact}

From the armchair of history it is understandable that a current analysis of World War One a hundred years later appears remote from the experiences of those alive at the time. For those who were eyewitnesses to the horror and destructiveness of the war, a vivid

\footnotetext{
${ }^{85}$ Withers, Hartley, (ed.), (27 December, 1919), The Economist, p. 1179.

${ }^{86}$ Markwell, (2006, p. 91).

${ }^{87}$ Markwell, (2006, p. 91).
} 
portrait resonates through time. Shortly following hostilities, on 7 November 1918, Keynes went on a week's tour through Belgium and Northern France. ${ }^{88}$ He later provided a description of what he saw

A journey through the devastated areas of France is impressive to the eye and imagination beyond description. During the winter of 191819 , before Nature had cast over the scene her ameliorating mantle, the horror and desolation of war was made visible to sight on an extraordinary scale of blasted grandeur. The completeness of the destruction was evident. For mile after mile nothing was left. No building was habitable and no field fit to plough. The sameness was also striking. One devastated area was exactly like another - a heap of rubble, a morass of shell holes, a tangle of wires.

To the British observer, one scene, however, stood out distinguished from the rest - the field of Ypres. In that desolate and ghostly spot, the natural colour and humours of the landscape and the climate seemed designed to express to the traveller the memories of the ground. A visitor to the salient early in November 1918, when a few German bodies still added a touch of realism and human error, and the great struggle was not yet certainly ended, could feel there, as nowhere else, the present outrage of war, and at the same time the tragic and sentimental purification which to the future will in some degree transform its harshness. ${ }^{89}$

Keynes reflected a cultural change that had taken place in Britain as the war unfolded. However, this change did not take place immediately. During and immediately following the war, Robb argues, the 'need for solace in remembering the war dead predominated, and most monuments celebrated the heroism and sacrifice of soldiers. ${ }^{90}$ But by the late 1920s and 1930s a more pessimistic and cynical view of the war had

\footnotetext{
${ }^{88}$ Moggridge, (1995, p. 285).

${ }^{89}$ Keynes, (1919, pp. 110-111).

${ }^{90}$ Robb, (2002, p. 208).
} 
emerged that competed with earlier patriotic interpretations. A spate of war novels, especially by veterans, contributed to the mood of disillusionment. Commemorations of the war dead increasingly were bound up with pacifist denunciations of the war itself, as well as criticism of the social and political order 'which some people now held responsible for so many 'meaningless' deaths. ${ }^{91}$

Composers, painters, dramatists, poets, and novelists all produced works inspired by the war, some of which continue to shape contemporary understanding of the conflict. ${ }^{92}$ Most authority figures during the early hostilities had promoted the war in a straightforward, patriotic manner, portraying the conflict as a just and heroic national crusade. However, as the war dragged on doubts grew and these artistic voices, especially those who had experienced combat began presenting war in a harsh and unflattering manner. This new stance represented a radical change in cultural sensibility. As the disillusionment grew the war was increasingly discredited as a barbaric and pointless exercise. The war artist Paul Nash had written to his wife during the war

Evil and the incarnate fiend alone can be master of this war, and no glimmer of God's hand is seen anywhere. Sunset and sunrise are blasphemous, they are mockeries to man, only the black rain out of the bruised and swollen clouds all through the bitter black of night is fit atmosphere in such a land. The rain drives on, the stinking mud becomes evilly yellow, the shell holes fill up with green-white water, the roads and tracks are covered in inches of slime, the black dying trees ooze and sweat and the shells never cease ... It is unspeakable, godless, hopeless. I am no longer an artist interested and curious, I am a messenger who will bring back word from the men who are fighting to those who want the war to go on forever. Feeble,

\footnotetext{
${ }^{91}$ Robb, (2002, p. 209).

${ }^{92}$ Robb, (2002, p. 129).
} 
inarticulate, will be my message, but it will be the bitter truth, and may it burn their lousy souls. ${ }^{93}$

During the 1920s it was accounts such as this that publishers drew on more frequently against that of the early war and immediate post-war accounts in praise of heroism and sacrifice. The many war poets who came after Rupert Brooke, the first British literary celebrity to crystallise the early idealism of the war in his poem "1914", found by 1916, in the face of the continuing slaughter on the Western Front, Brooke's idealism was difficult to sustain. Their poetry increasingly presented the war in a harsh and unglamorous light, as in Arthur Graeme West's "The Night Patrol":

Only the dead were always present - present

As a vile sickly smell of rottenness;

The rustling stubble and the early grass, The slimy pools - the dead men stank through all ...

Isaac Rosenberg described an apocalyptic scene of battlefield carnage:

The wheels lurched over sprawled dead

But pained them not, though their bones crunched,

Their mouths made no moan.

They lie there huddled, friend, and foeman,

Man born of man, and born of woman,

And shells go crying over them

From night till night and now. ${ }^{94}$

${ }^{93}$ Quoted in Cork, (1994, p. 198), cited in Robb, (2002). 
Poetry was complemented with prose from authors such as Graves, Aldington, Sassoon, and Williamson, who depicted the squalor of the trenches and the horrors of frontline experience. They savagely debunked the popular romantic image of warfare. For them, death was not pretty and these authors had no intention of making it so. Graves recalled in his memoir Good-Bye to All That:

I saw a group bending over a man lying at the bottom of the trench. He was making a snoring noise mixed with animal groans. At my feet lay the cap he had worn, splashed with his brains. I had never seen human brain before; I somehow regarded them as a poetical figment. One can joke with a badly-wounded man and congratulate him on being out of it. One can disregard a dead man. But even a miner can't make a joke that sounds like a joke over a man who takes three hours to die, after the top of his head had been taken off by a bullet fired at twenty yards' range. ${ }^{95}$

If the soldiers who fought in the war experienced the worst of it then it was just a matter of 'relatively worse.' Deprivation extended to all sectors of societies, both for the Allies and the Central Powers. In Germany the war had deprived people of sufficient quantities of the basic necessities of life, the problem of insufficient food for the civilian population arising early. Coal shortages developed in the winter of 1916-17 and in the last year of the war there were serious shortages of clothing and housing. The clothing supply had deteriorated sharply because of the shortage of raw materials and the use of inadequate "substitute" products. Shoes were in particularly short supply. No less serious was the shortage of soap. Coal miners could not wash properly after work, and housewives were unable to keep clothing clean. Many German workers were being forced

\footnotetext{
${ }^{94}$ Silkin (1996, p. 221).

${ }^{95}$ Graves, (1981, p. 107).
} 
to contend with lice. Finally, the flood of workers into the war production centres created a housing shortage and a rapid rise of rents. ${ }^{96}$

Germany's domestic problems were because of poor management and organisation, farmers and peasantry being the worst affected, with the organisation of the food supply system largely ignoring their needs. Feldman argues, the exaggerated importance of the industrial workers during the war created a new type of social injustice, and the sufferings of the workers, however real, 'must not be permitted to blind one to the extraordinary hardships suffered by other classes. ${ }^{, 97}$ The plight of the farmers was 'truly miserable.' The army had sequestered their best horses. They did not have sufficient labour, and the peace with Russia threatened their most important source of prisoners of war. They had been forced to engage in massive pig slaughters, and they did not have enough fodder for the remaining livestock. They were encumbered by hundreds of regulations and victimised by periodic searches for hidden food stores. Their land was being ruined by over-cultivation and the storage of artificial fertilisers.

As bad as these privations were, they at least had farmland untouched by the ravages of war. In northern France by contrast, where Keynes had toured and where the worst of the fighting had taken place, the landscape as well as the economy and society was 'appalling. ${ }^{98}$ After four years of warfare, the battle zone of Pas-de-Calais formed 'a panorama that had never been seen before.' Weeds flourished among shell holes, trenches, barbed wire and concrete bunkers, carpeting the countryside with different vegetation from the cereals and lush fodder that it had supported for so long before the war. Across some stretches every tree had been felled by gunfire or had been cut down intentionally and 'no bird song was heard; no birds remained.' Whole villages had been

\footnotetext{
${ }^{96}$ Feldman, (1992, p.p. 459-460).

${ }^{97}$ Feldman, (1992, p. 463).

${ }^{98}$ Clout, (1996, p. 20).
} 
destroyed in the fighting or had been mined as the Germans withdrew. Numerous commentators would suggest they resembled a 'lunar landscape.' Districts away from the battle zone were less affected but they too suffered from damage caused by the enforced presence of troops and by the effects of scorched earth policies. ${ }^{99}$

\subsubsection{Economic Dislocation and Turmoil}

This social and cultural impact was largely attributable to the economic instability following hostilities. As has been highlighted, Europe found itself unable to return to the laissez-faire system. Contributing to this was the way in which the demographics of Europe were affected. Military and civilian death tolls, combined with a fall in the birth rate, left Europe (without Russia) facing a 22-24 million population deficit. Another 7 million people were permanently disabled. Russia lost nearly 16 million people during the war, revolution and civil war, and suffered a birth deficit of around 10 million. Between 1914 and 1921, due in part also to the decline in the birth rate and the "Spanish" flu epidemic, Europe had lost 50-60 million people. ${ }^{100}$ There was also a change in thinking taking place among politicians and policy makers, both domestically and internationally that increasingly challenged laissez-faire in favour of greater government intervention and inter-governmental action in economic affairs.

The Amsterdam Memorial is an example of these early efforts, which stressed the role of business, and sought a liberal trading order with the help of governments. ${ }^{101}$

${ }^{99}$ Clout, (1996, pp. 21-22).

${ }^{100}$ Aldcroft, (1978, pp. 6-8).

${ }^{101}$ Markwell, (2006, p. 91). In 1919 several American bankers together with leading British and Dutch financiers, were instrumental in drafting the Amsterdam Memorial, which was signed by many leading European and American statesmen, bankers and industrialists. This international petition called for the extension of large-scale American credits and loans to European governments and businesses, lenient intergovernmental debt settlements, a reparations assessment relatively generous to Germany, and a readiness on the part of both Americans and Europeans to make sacrifices for these ends. The Amsterdam Memorial led the League of Nations in 1920 to endorse the Meulen plan, named after the Dutch banker, ...Footnote continued on next page... 
Despite having left the peace conference early Keynes continued to be involved in discussions around the needs of post-war reconstruction, including meetings with a group of European and American financiers in Amsterdam during October and November 1919. He had earlier agreed, at Norman Angell's request (July 1919) to join an Economic Subcommittee of the Fight the Famine Fund. ${ }^{102}$ Angell wished to use famine relief as a means of getting 'sounder public opinion on broader issues of international policy.' ${ }^{103}$ Keynes, along with a number of financial experts, many of whom had been at Paris, met unofficially in Amsterdam and agreed the 'Memorial,' which among other proposals envisaged renewed international lending, and was submitted to governments in midJanuary 1920. While a number of the proposals received a mixed reception, American intransigence was an indicator of how a comprehensive plan of governmental leadership was alien to laissez-faire ideas. But Amsterdam proved to be an early exercise in a new private diplomacy among the élite of financiers and financial experts that was an important initiative as a wide range of individuals looked for ways of bringing stability and "normalcy" back to Europe. ${ }^{104}$

Another reason for Europe's economic turmoil and failure to return to "normalcy" was the consequences from the physical destruction of the war. This was most pronounced in the battlefield countries of Belgium, France, Poland, Serbia, and Russia. The Allied Reparation Commission assessed their war damages at $f 6.6$ billion. ${ }^{105}$ Belgium alone

which called for European governments to issue bonds that could be used to guarantee private credits to finance Europe's recovery. Source: Roberts, (2010).

102 Markwell, (2006, p. 91).

${ }^{103}$ Angell to Keynes, 20 July 1919, King's College Archives, JMK/L/19/43.

${ }^{104}$ Markwell, (2006, p.100).

${ }^{105}$ Kenwood and Lougheed, (1971, p. 192). Like many figures we have from the World War One period these need to be treated with some caution. Unreliable statistics, difficulty with verification and methodological issues around calculation were problems in the compilation of statistics from this era and many remain in dispute to the current day. However, it is the sense of scale that should be the main concern when trying to ...Footnote continued on next page...

Page 171

8-Jun-11 
lost roughly $6 \%$ of its housing, half its steel mills, and three quarters of the rolling stock of the railroads. France came out of the war almost bankrupt, with large debts and some $10 \%$ of her territory devastated. A quarter of French men between eighteen and thirty had died in the war, over 1.3 million altogether out of a pre-war population of 40 million. Twice as many again of its soldiers had been wounded. In the north great stretches of land were pitted with shell holes, criss-crossed by trenches, marked with row upon row of crosses. The coal-mines on which the French economy depended for its power were flooded; the factories they would have supplied had been razed to the ground or carted away to Germany. Six thousand square miles of France, which before the war had produced $20 \%$ of its crops, $90 \%$ of its iron ore and $65 \%$ of its steel, were utterly ruined. ${ }^{106}$ France was a creditor country before the war but emerged from the war deeply in debt, faced with a bill of \$US 3.7 billion owed to the United States and Britain.

Defeated and exhausted, Germany experienced a nutrition crisis. The Times of November 19, 1918 carried a plea from the German government to the Allied victors for immediate assistance across a broad economic front, especially for transport to enable food to be carried to the many who were dislocated and starving. The German wireless service claimed,

we [find] ourselves in such a position that we should not be able to guarantee a supply even for a week, and as the conditions in the east and west, north and south, are identical, we are forced to the conclusion that in all points of the Empire hunger would supervene,

construct a picture of economic context. In this example, even if the war damages figure of $£ 6.6$ billion used by the Allied Reparation Commission could be disputed it stands alone as a significant enough figure that a variation either way of more than a few percentage points would not undermine the argument that physical damage from the war years stands as an important explanation for Europe's inability to return to pre-war economic conditions.

${ }^{106}$ Macmillan, (2001, p. 36). 
owing to the difficulties of transport, the consequences of which would be incalculable! ${ }^{107}$

The Versailles Treaty cut off $15 \%$ of the country's arable land, $75 \%$ of its iron ore, and $26 \%$ of its coal resources. Iron and steel production capacities dropped $44 \%$ and $38 \%$ respectively. Germany lost $90 \%$ of its merchant fleet, its entire navy, a great part of its railway rolling stock, and all its foreign investment. By 1919, German industry produced little more than one-third of its 1913 output levels. By 1923, industrial production overall still had not reached half the pre-war level. ${ }^{108}$ The reality of physical decline and destruction affected surrounding European countries. For example, within the new borders of Poland 1.8 million buildings were destroyed. Half of the railway bridges and station buildings were ruined. Serbia, also a battlefield, lost half of its animal stocks. Bulgarian agricultural output dropped to $57 \%$ of the pre-Balkan war levels, while industrial production was still 20\% lower in 1921. Romanian crude oil output did not reach half the pre-war level until 1921. In Austria the effects of war were particularly acute and had been since the beginning of 1918. The Times of April 3, 1918 carried extracts from a report prepared for the Bureau of Labour Statistics in Washington on social and economic conditions in enemy countries. In Prague

a great part of the population suffers from hunger, and the children suffer both physically and morally. The number of child beggars in Prague has gone up to several thousands, the death rate among the general population increasing daily. Diarrhoea is spreading at an alarming rate in Prague. ${ }^{109}$

\footnotetext{
107 Dawson, George Geoffrey, (ed.), (19 November, 1918), “Armistice Terms: Another German Protest: "Economic Conditions Menaced"," The Times, p. 6.

${ }^{108}$ Berghan, (1987, pp. 276-277).

109 Dawson, George Geoffrey, (ed.), (3 April, 1918), "Enemy Economic Conditions: Austrian Hardships: Jealousy of Hungarian Plenty," The Times, p. 4.
} 
By the end of 1918 agricultural production had fallen by half, and milk consumption in Vienna dropped to $7 \%$ of pre-war levels; cut off from former raw material resources, industrial output reached only one-third of pre-war levels in $1919 .{ }^{110}$

The economic effects of dislocation and disruption show up in the most widely used measure of economic performance, GDP (refer to Table Six below). For example, Western Europe did not regain its 1913 level of real GDP until $1924{ }^{111}$ Extensive growth had been set back in Western Europe by eleven years. Maddison maintains that in the case of Czechoslovakia and Yugoslavia, 1913 levels of real GDP were not reached again until 1923, Hungary in 1925, Bulgaria in 1927 and Russia in 1929. Even in those countries where physical damage was minimal, GDP growth experienced setbacks. In Britain's case trade had been an early casualty of war and as a result industrial production declined. Output in 1920 stood at 1913 levels, but then fell roughly 20\% in 1921, and did not recover until 1924. GDP had reached 1913 levels by 1919 but subsequently declined between 1920 and 1922 by $16 \%$ and did not recover until 1927. Before World War One Britain had been the world's leading foreign investor and financial power. During the war her overseas capital holdings declined by $25 \%$, and invisible income from financial transactions decreased by $25-33 \%$. Both Alford and Pollard argue, Britain's prosperity, prior to war, had largely depended on her ability to generate large and increasing surpluses on international financial transactions. This capability was lost as a result of the war. $^{112}$

\footnotetext{
${ }^{110}$ Berend, (1974, pp. 174-177).

${ }^{111}$ Maddison, (1995, p. 66).

${ }^{112}$ Alford, (1996, pp. 107-109); Pollard, (1973, p. 52).
} 
Table 6: Annual average growth rates of real GDP, 1913-29 (\%)

\begin{tabular}{|c|c|c|c|c|c|}
\hline \multicolumn{2}{|l|}{ Neutrals } & \multicolumn{2}{|c|}{ Winners (European) } & \multicolumn{2}{|l|}{ Losers } \\
\hline Sweden & 1.9 & UK & 0.7 & Austria & 0.3 \\
\hline Finland & 2.4 & Belgium & 1.4 & Germany & 1.2 \\
\hline Denmark & 2.7 & Italy & 1.7 & & \\
\hline Switzerland & 2.8 & France & 1.9 & & \\
\hline Norway & 2.9 & & & & \\
\hline \multirow[t]{4}{*}{ Netherlands } & 3.6 & (extra-Eu & & & \\
\hline & & Canada & 2.5 & & \\
\hline & & USA & 3.1 & & \\
\hline & & Japan & 3.7 & & \\
\hline
\end{tabular}

Source: Feinstein, Temin, and Toniolo, (1997, p. 13).

Unlike the countries at war, most of the neutral states emerged from the war and the immediate post-war years with stronger economies and higher incomes. The Netherlands, Spain, Norway, and Switzerland increased their per capita GDP by 19,15, 11, and 9\% respectively, between 1913-14 and 1922-24. At the end of the war, however, because of shortages of energy, raw materials, and markets, and because of revitalised international competition and sharply restricted export possibilities, the neutral countries suffered setbacks. None of the European countries escaped the negative consequences of the war. However, economic growth was not as badly affected in other parts of the world. The American and Japanese economies forged ahead in the 1920s, seemingly impervious to the difficulties in Europe. Levels of GDP in Latin America and Asia continued to expand in the same period, despite weaker commodity prices. On the other hand the then developing world was not completely insulated from the after-effects of war. For example, the price of Malaya's main export commodity collapsed in the global recession of 1920-22 
although it did recover to a record high in 1925. In high-income primary producing countries, such as New Zealand, the main effect was felt in the fluctuations in world demand and prices in the 1920s. Declining real capital outflows from the core European countries, including Britain, posed additional problems for peripheral countries, which were only partially relieved by increased supplies of American capital. ${ }^{113}$

In this story of turmoil, runaway inflation was one of the most frightening economic phenomena. This was due to a number of factors, including the financing of the war economy, the accumulation of huge debts, severe declines in agricultural and industrial production, the heavy burden of reconstruction, and, in some cases, reparation payments. Five countries, Germany, Austria, Hungary, Poland, and Italy, were hard hit by hyperinflation with Germany particularly badly affected. On January 17, 1920 The Economist reported,

[the] general inflation of prices counts as a serious danger for Germany in the coming year, because it shows no sign of abating. Prices of commodities rise so rapidly that no general index can be kept. The figures for isolated commodities indicate that the rise goes on not in arithmetical, but in something like geometrical progression. A single increase in the last few weeks has often exceeded by several hundred per cent the whole peace price. A good instance is pig-iron, the price of which (haematite) was raised by 436 marks a ton on the $1^{\text {st }}$ of the month; its price in 1914 was 79.50 marks. ${ }^{114}$

In November 1923 \$US 1 attained the rate of 4.2 billion German marks. Thirty paper mills, 150 printing firms, and 2,000 printing presses worked 24 hours a day to provide valueless money. The price of a kilogram of butter reached 5 billion marks and the Reichsbank printed 1,000 billion mark notes. The country fell back on barter trade so that the price of

\footnotetext{
${ }^{113}$ Singleton, (2007, p. 31).

${ }^{114}$ Withers, Hartley, (ed.), (17 January, 1920), "Germany - prospects for 1920 - Expenditure and Taxes Bourse Conditions in 1919 - Price Inflation - Employment - Coal Troubles," The Economist, p. 16.
} 
a haircut was four eggs, a first-class burial, forty. ${ }^{115}$ Economists, including Keynes, warned that inflation was a serious threat to social cohesion and saw it as a threat to capitalism, because it discouraged saving and bred animosity towards entrepreneurs, who were branded as profiteers. ${ }^{116}$ Fuelling the inflationary threat were attempts to block tax rate rises. Opposition came from sectional interests, while the appetite of domestic and foreign investors for government debt was limited. The Central Powers found it harder to borrow abroad than did Britain and France, with all belligerents resorting in some measure to the printing press or inflation tax. ${ }^{117}$

The leading powers before the war had committed to ensure the spectre of inflation was contained. This had been achieved, by and large, through the successful operation of the pre-war gold standard. The standard had involved unlimited convertibility of major currencies into gold at fixed exchange rates but with inflation no longer being able to be contained, rising current deficits and declining investor confidence, European countries were forced to restrict or suspend gold convertibility after 1914 , in order to stop the loss of gold reserves. At the end of the war efforts were made to restore conditions back to pre-1914 and as many as sixteen countries sought to stabilise currencies through restoration of the gold standard between 1923 and 1926, and another four in 1927-9. However, by this stage the international economic system had been so weakened through a lack of leadership, co-operation was undermined and international economic chaos posed increased risk to all countries, thwarting efforts to use pre-war methods. ${ }^{118}$

\footnotetext{
${ }^{115}$ Berend, (1974, p. 51).

${ }^{116}$ Moggridge, (1995, p. 333).

${ }^{117}$ Singleton, (2007, p. 36).

${ }^{118}$ Berend, (1974, p. 56).
} 
Lack of co-operation and the inability to return the world to pre-war prosperity were exacerbated by the continuance of nationalism and great power rivalries. The victorious Allied countries sought to strengthen their dominant position while the disillusioned, defeated and peripheral countries, and those who believed they had been cheated by the victors, revolted. An idealistic President Wilson spoke of "peace without victory," freedom and equal status for all nations without great power interference, collective security, guaranteed by a newly established League of Nations, and the right of self-determination for all nationalities. However, America soon withdrew from international politics and peace-making. Instead of taking the lead and helping to build an international world order, the US retreated into isolationism and became preoccupied with domestic affairs.

According to Komlos the most momentous consequence of the war in this new nationalistic world order (or, rather, disorder) was the disintegration of the AustroHungarian Empire. ${ }^{119}$ At the turn of the twentieth century the Hapsburg Empire had been economically active, despite being politically moribund. Trade had flourished within this Central European customs union but after 1918 trade between the former Hapsburg states may have fallen by as much as one-half. Countries that grew out of the old empire were economically unbalanced. Czechoslovakia inherited the empire's most advanced industrial region, leaving Austria relatively underdeveloped. Hungary was cut off from its main sources of raw materials. High trade barriers were erected as each country sought to develop a distinct national economy. Hungary was on particularly bad terms with its neighbours. Bad blood stretched back into the war years when Hungary was accused of profiteering at the expense of countries such as Austria, who were considered worse off. ${ }^{120}$ Singleton argues, 'financial and commercial networks in Central Europe were

\footnotetext{
${ }^{119}$ Komlos, (1983).

${ }^{120}$ During the war, a report from a debate in Austria's Lower House of the Reischsrath quoted one of the Deputy Food Administrators, Kraft, as saying that out of the fat imported to Austria-Hungary by way of Germany seven-twelths went to Austria and five-twelths to Hungary. "What does Hungary want this extra ...Footnote continued on next page...
} 
shattered and the gains from regional specialisation were lost. Intra-regional trade declined relative to trade with Western Europe. ${ }^{121}$ Added to the negative consequences of Austro-Hungary's collapse was resentment of the peace settlement, which created new territorial grievances.

Poland, and what would become Yugoslavia, faced problems of a different, but equally disruptive, nature. Their task was to integrate regions, transport systems, and business networks that had until recently been in separate states. Yugoslavia inherited five practically unrelated railway systems, and four gauges of track. ${ }^{122}$ Stimulated by protectionism, industry expanded rapidly in most parts of Central and Eastern Europe during the 1920s but it is doubtful that many countries, with the exception of Czechoslovakia, were internationally competitive. The new states of Central and Eastern Europe obtained relief and reconstruction loans from the Allies and the League of Nations, but the amounts were, argues Singleton, too small to have more than a moral effect. ${ }^{123}$ On the other hand, inflows of foreign investment were considerable, especially into extractive industries such as mining and oil production and into the Czechoslovakia manufacturing sector.

\subsubsection{The Issue of Reparations}

But this inflow of foreign investment was a bright spot on an otherwise gloomy picture of economic struggle and turmoil. The Conference of Versailles and the resulting Peace Treaty were symbolic of everything wrong economically and politically with Europe. An

fat for?" he asked, "she already has surplus fat of her own. She wants it to re-export to Austria at fabulously increased prices. Austria should compel Hungary to observe a minimum of decency in these matters." Dawson, George Geoffrey, (ed.), (3 April, 1918), "Enemy Economic Conditions: Austrian Hardships: Jealousy of Hungarian Plenty," The Times, p. 4.

${ }^{121}$ Singleton, (2007, p. 32).

${ }^{122}$ Aldcroft, and Morewood, (1995, pp. 1-41).

${ }^{123}$ Singleton, (2007, p. 32). 
editorial in The Times on November 19, 1918, written in response to German requests for help reflected the unhelpful mood and attitude of the victorious Allies.

The German Government ... must really accommodate itself to the fact that it speaks for a defeated nation. These daily whines about "the menace to economic conditions" come with singular ill-grace from the people who ravished Belgium and Northern France, and boasted joyfully that they would starve this country into submission. The Allies have declared themselves bound by the common appeals of humanity, but they will not be moved from conditions of armistice, which guarantee their own security against a repetition of these crimes. $^{124}$

To many contemporaries the peace was nothing more than the continuation of war by other means. For example, they pointed out how France's plan was to weaken its arch-enemy, Germany, as far as possible. Article 233 of the Versailles Treaty declared Germany would have to pay for the destruction and damage of the war, and the amount "shall be determined by an inter-Allied commission, to be called the Reparation Commission." The Commission, under strong French pressure, decided on a \$33 billion reparation obligation for Germany in April 1921. Even Lloyd George, no saint when it came to British intentions to constrain Germany economically, wrote later that 'French claims were at the outset of a most extravagant character.' France had demanded 75 billion francs for devastation of buildings in northeast France, which represented $4 \%$ of the territory of the country, while official French statistics in 1917 had valued the housing properties of the entire country at only 59.5 billion francs. ${ }^{125}$

These demands now appear to have been opening gambits as reparations extracted were far more modest. Furthermore, revisionist history has sought to redeem

\footnotetext{
${ }^{124}$ Dawson, George Geoffrey, (ed.), (19 November, 1918), “Armistice Terms: Another German Protest: "Economic Conditions Menaced"," The Times, p. 6.

125 Lloyd George, (1932, pp. 18-20).
} 
the French as "rather hard done by." For example, Trachtenberg argues, 'the old idea of a vindictive French reparation policy, and more generally the idea of a vengeful France intent on destroying the German Reich, no longer seem tenable. France appears, not forceful and violent, but rather weak, too weak to stand by herself ... the Clemenceau government sought salvation not through the crushing of Germany but rather by linking up with the British and the Americans. ${ }^{126}$

Singleton argues the roots of the reparations issue are to be found in the ways in which the war had been financed. Taxing, borrowing and printing money financed warrelated expenditure. ${ }^{127}$ After the war, governments had to decide what to do about their vast accumulated debts. While higher taxes or levies, more inflation and default were the main options, Allied politicians aligned themselves against the defeated powers and insisted they should reimburse the victors for at least some of the financial costs of the war, including war pensions.

Trachtenberg argues that the reason for the Allies seeking reparations was primarily due to the ungenerous policy of the United States, which was unwilling to accept any substantial share of the burden of reconstruction. He also argues that France would have preferred an inter-Allied solution to the one elaborated in the Treaty, something they continued to press for into the early 1920 s as 'they had no desire to use reparation as a way of crushing Germany, as the moderation of their policy demonstrates quite clearly. ${ }^{128}$ There is a view that even the British could have been brought around to a mild reparation settlement if it had been linked to a generous American policy of economic assistance to Europe, evidenced by Lloyd George's awareness of the need to face up to the wider problem of European economic recovery. But Trachtenberg is not so convinced,

\footnotetext{
${ }^{126}$ Trachtenberg, (1979, p. 53).

${ }^{127}$ Singleton, (2007, p. 33).

${ }^{128}$ Trachtenberg, (1979, pp. 51-52).
} 
and does not accept the view held by some that Lloyd George was an appeaser in temperament and outlook. In private he repeatedly expressed his preference for a harsh settlement, an attitude that reflected liberal thinking on international politics.

Trachtenberg argues of Lloyd George's views, 'if the natural order of things was peaceful, it followed that only aggression could cause wars; to establish peace, to satisfy the demands of justice, to introduce the rule of law into the international sphere, aggression had to be punished.' ${ }^{129}$

This was the attitude against which Keynes was so vehemently opposed. He predicted in Economic Consequences demands for reparations would lead to economic disaster in Germany and a lengthy period of international economic instability. As has been highlighted, a number of contemporary commentators saw these arguments as the views of a pro-German sympathiser while many later economists judge Keynes as having exaggerated both his argument on Germany's capacity to pay and the figures he used to make his case. On the first of these points Singleton makes the argument that it was doubtful whether the Allies ever expected Germany to pay more than the first 50 billion gold marks, itself not excessive, of the 132 billion gold marks outlined in the 1921 London Schedule of Payments. ${ }^{130}$ Furthermore Germany's allies were treated leniently and 'the states of the former Austro-Hungarian Empire were asked for token reparations, and Turkey was pardoned. ${ }^{131}$

The 1921 London Schedule of Payments marks an important cross road in the reparations issue. The Versailles Conference had deliberately kept open the actual size of the final reparation bill and it was not until May 1921 final figures were agreed upon and

\footnotetext{
${ }^{129}$ Trachtenberg, (1979, pp. 51-52).

${ }^{130}$ The gold mark was an abstraction based on the American dollar - four gold marks to the dollar. Thus, 132 and 50 billion gold marks respectively were $\$ 33$ and $\$ 12.5$ billion. Source, Felix, $(1971$, p. 173). Expressed in $\mathrm{f}$ sterling the figure of $\$ 33$ equated to roughly $\mathrm{f6.6}$ billion.

${ }^{131}$ Singleton, (2007, p. 33).
} 
accepted by Germany, albeit under threat of occupation of the Ruhr. There was also the start of much of the confusion that developed around what the reparation figures actually meant, a confusion which continues to the present day, as Sally Marks makes clear in "The Myths of Reparation." ${ }^{132}$ While historians have focused upon the figure of 132 billion gold marks, the London Schedule of Payments of May 5, 1921 'both enshrined this sum and demolished it.' The full liability for all the Central Powers combined, not just Germany alone, was set at 132 billion gold marks, subject to certain arithmetic adjustments. ${ }^{133}$ The German debt, however, was to be organised in three series of bonds, labelled A, B, and C. Of these, the $\mathrm{C}$ bonds, which contained the bulk of the German obligation, were deliberately designed to be chimerical. They were entirely unreal, and their primary function was to mislead public opinion in the receiver countries into believing the 132 billion gold mark figures was being maintained. Allied experts knew Germany could not pay 132 billion gold marks and the other Central Powers could pay little. Thus the $A$ and B bonds, which were genuine, represented the actual Allied assessment of German capacity to pay. The A bonds, amounting to 12 billion marks, constituted the unpaid balance of the interim 20 billion, while the $B$ bonds represented German reparations liability to a face (or nominal) value of 50 billion gold marks or $\$ 12.5$ billion, an amount smaller than what Germany had recently offered to pay. The London Schedule also established modalities of payment toward redemption of the $A$ and $B$ bonds, including two schedules of quarterly deadlines for fixed and variable annuities. ${ }^{134}$

Keynes was deeply hostile to this agreement because it carried ultimatums for Germany that involved sanctions, territorial incursions and discriminatory tariffs, if used.

\footnotetext{
132 Marks, (1978, pp. 231-232). While Marks acknowledges that the myths around reparations started with the Versailles Treaty it was not until the 1921 Schedule was agreed that most of the misunderstanding around the figures really began to develop.

${ }^{133}$ Marks, (1978, p. 231).

${ }^{134}$ Marks, (1978, p. 237).
} 
He believed it displayed 'contempt for the due form and processes of law,' and would not raise any money from Germany. ${ }^{135}$ These became his familiar themes of criticism up until the occupation of the Ruhr in 1923. He did, however, applaud the Reparation Commission's determination of Germany's liability on 27 April as being lower than his estimates in Economic Consequences and this, in his opinion, was a 'signal triumph for the spirit of justice.' The London Schedule was the scheme for the payment of this liability. However, even though Keynes saw the 1921 Schedule as a return to the Treaty, he held to his previous position that the Treaty itself remained impossible to fulfil as he still believed the reparations imposed were beyond Germany's capacity to pay. ${ }^{136}$

The actual total amount paid by Germany of 20.598 billion gold marks would no doubt have been seen by Keynes as a vindication of his views, although most economists are not persuaded that reparations imposed were beyond Germany's capacity to pay. ${ }^{137}$ Ferguson argues, the actual amount of reparations paid by Germany during the early 1920s was equivalent to between 4 and 7 per cent of national income, hardly a crippling burden, especially in comparison with the material losses borne by the German population during the war itself. ${ }^{138}$ When Germany descended into hyperinflation, the Weimar government said it could no longer meet the London Schedule of Payments and in 1924 Germany obtained the rescheduling of its financial obligations under the Dawes Plan. Contrary to the argument that it was America's lack of generosity that inflamed the reparations issue, German payments following the Dawes Plan were actually facilitated by a large inflow of US private capital. These hardly seem the actions of an ungenerous nation, although investors were private citizens driven by commercial imperatives. But

\footnotetext{
${ }^{135}$ Markham, (2006, p. 124).

${ }^{136}$ Markham, (2006, p. 125).

${ }^{137}$ Marks, (1978, p. 233).

${ }^{138}$ Ferguson, (1996, p. 656).
} 
Germany did finally default in 1932 during the Depression. Some estimates suggest as little as 17 billion gold marks were paid in reparations, although this figure is disputed. Despite the dispute around the actual final sum paid, it was nevertheless a fraction of the original bill. ${ }^{139}$

David Felix takes issue with both the estimate of 17 billion gold marks and with those who argue that Germany was "let off lightly." As long as there was an insistence on the repayment of the large debts incurred during the war, any further debt was added to an accumulating deficit, which in turn meant any subsequent amount of economic growth would be lost on debt repayments when economic restoration was badly needed. ${ }^{140}$ Arguing that Germany was unable to pay for war damages, Felix addresses the issue of statistics. Students of the war often draw on a selective range of numbers to support the view Germany was capable of meeting reparation amounts imposed by the Allies. Felix's assessment is that 'the statistics lie.' Using an estimate of 22.9 billion gold marks WeillRaynal argues was paid by Germany, ${ }^{141}$ Felix maintains this figure conceals innumerable questionable decisions about the valuation of goods, interest payments, and other items. For example, it does not credit Germany with many transfers of wealth it made, including the mines of the Saar, and public works and steel mills in Lorraine. Also ignored are the malformations in the German economy and the costs, perhaps 3.5 billion gold marks, of the Ruhr occupation.

Often the counter argument to this is that, in any event, the Allies wholly funded actual reparation payments and it achieves nothing to add back the amounts Felix

\footnotetext{
${ }^{139}$ Schuker, (1988, p. 106-108) from Singleton, (2007 p. 34).

${ }^{140}$ Ritschl, (2005, p. 62), cautions about the reliability of German statistics from the World War One period but nevertheless shows much of Germany's war financing as being dependent on increasing amounts of debt as the war progressed. In 1914/15 debt increased by 11,513 million marks, 1915/16 22,781, 1916/17 29,381, 1917/18 36, 067 and 1918/19 51,148.

${ }^{141}$ Weill-Raynal, (1938, p. 47) from Felix, (1971, p. 176).
} 
identifies. Compared to the figure of $\mathbf{2 2 . 9}$ billion gold marks, foreign investors, after, and despite losses of 7.6 to 8.7 billion gold marks invested from 1919 to 1923 , sent still more money, the equivalent of 25.5 billion gold marks, into Germany from 1924 to 1930 . This was the source of revenue Germany used to pay reparations under the Dawes and Young Plans. When Germany slid into acute financial crisis on the heels of the September 1930 election, German leaders began to seek reparations relief, although the initial credit crisis was caused primarily by a dramatic flight of capital in response to Hitler's electoral success, not by reparations. Hoover had reacted to American investor concerns by proposing a year-long moratorium on reparation payments but when he found it impossible to extend this, through internal political pressure, Britain and France called the Entente powers and Germany together at Lausanne in June 1932 to effect a "lasting settlement." When it became clear nothing would come of inviting Hitler to discuss payment 'reparations were never formally cancelled, but fell into limbo as they became increasingly unrealistic. ${ }^{142}$

Felix asks the question: why had the Allies let Germany cheat them so completely? In answer to his own question he argues, rather than having any plan to deliberately cheat, both the Germans and the Allies were doing what had to be done. Germany could only pay in one of two ways; either by handing over part of her national wealth; or by drawing upon revenues produced by current income, the latter from returning a trade surplus. But, he argues, the national wealth, estimated at 250 billion gold marks, 'resisted exploitation'. The most negotiable part was represented by the great industries, and taking them over would have meant nationalisation, and, more than that, possible revolution. The Allies did not want a German revolution. Furthermore, it was the great industries that were attracting foreign funds with any moves to nationalise most likely resulting in foreign funds drying up. Had these arguments been ignored it would have been necessary to sell securities on the Allied money markets so as to transform German

\footnotetext{
142 Marks, (1978, p. 254).
} 
property holdings into cash. In Great Britain the fear was, if this were to occur such sales might lead to speculation and give German industry a preference over Britain, thus giving foreign countries an interest in German domestic affairs. ${ }^{143}$

The argument that Germany could have funded payments from current income also has a complication as Germany's trade was static over the 1920 s. $^{144}$ In reality the entire German economy was weak in the 1920s. Industry was short of capital, the financial markets were disorganised, the savings of countless Germans had been obliterated as a result of inflation, there was a chronic current balance-of-payments deficit at every level of activity, and agriculture, an important sector of activity, was in a critical condition. In short, Germany was on the cusp of severe depression. ${ }^{145}$ Contributing to Germany's woes was the resistance from Allied leaders to let her build up surpluses because this would have reduced employment in their own countries. As it was, Britain was under intense competition from a number of directions. Japanese and Indian competition, plus an overvalued pound and pressure from German exports meant Britain experienced an unemployment rate averaging 10 per cent during the decade. In effect, the Allies, while pressuring Germany to get extra payments out of her, were refusing her the means of earning or paying money.

With no effective means of Germany earning her way out of reparation demands and with the only way to pay being from fully funded foreign loans, meant that Germany had no economic capacity to enable any form of reparations to be made. Felix argues 'in the spring of 1921, when the reparation debt was determined, Germany was in deep economic difficulty.' This was primarily due to Germany's level of indebtedness and

\footnotetext{
${ }^{143}$ Weill-Raynal, (1938, p. 47) from Felix, (1971, p. 177).

${ }^{144}$ Falkus, (1975, p. 453).

${ }^{145}$ Falkus, (1975, p. 452).
} 
inability to get into a position where the Germans could get the situation under control. ${ }^{146}$ For the financial year from April 1, 1920, to March 31, 1921, just before the London Payments Plan went into effect, the German government had a general operating deficit of 6 billion gold marks. Income of 3,178.1 million gold marks had been derived from taxes and 97 million gold marks in other receipts. But, expenditures had been 9,328.7 million gold marks. The deficit was a sixth of annual national income, then about 35 billion gold marks. ${ }^{147}$ The German government had escaped bankruptcy only by inflating the currency and debts were piled upon previous deficits. According to Felix, it is not surprising the London Payments Plan broke down within a few months, even if the debts taken on their own seemed modest figures.

When Germany did remit a billion gold marks under Allied orders they got the money by selling paper marks on the foreign-currency exchanges. However, the paper mark fell to a fifth of its value in half a year, going from 60 to 310 by November 8,1921 and setting in motion a slide into a set of inflationary pressures Germany found they could not get out of. The Allies attempted a succession of other plans and in January 1922, the first one, called for somewhat lower payments and the transforming of some of the cash requirements into payments in kind. This new arrangement, however, was permitted to disappear in August 1922 when, the mark went from 643 to 1,725 to the dollar. At the same time, Raymond Poincaré, France's hard-line premier, 'participated in still another saving deception' by permitting the acceptance of German treasury notes in lieu of cash as reparation payments, although he knew the notes, without the backing by gold or foreign currency, were worthless. Driven by angry French public opinion, Poincaré sent troops into the Ruhr on January 11, 1923. This occupation failed to produce the cash France was demanding but it destroyed the mark, which went from 7,260 on January 2 to 4 trillion on

\footnotetext{
${ }^{146}$ Felix, (1971, p. 173).

${ }^{147}$ Felix, (1971, p. 173). Felix takes his figures from official German statistics of the period; Germany, Statistisches Amt, Wirtschaft und Statistik (1924), IX (bound monthly bulletin), 276, table.
} 
November 20, 1923. The mark was withdrawn from circulation at this point. These events played back on France, with the franc falling precipitously and the French economy suffering 'incalculable losses.' ${ }^{148}$

Reparations dominated the political life of the Weimar Republic in Germany until its breakup. After the occupation by the French and the disorder and insecurity created by inflation, the Dawes Plan, permitted Germany to recover along with the rest of the world. The Dawes Plan had begun with a virtual moratorium, assisted by a loan of $\$ 200$ million to Germany, for the first year, and a partial moratorium for the next two years. The problem was not solved, just postponed, and the yearly payments kept increasing. Despite making slow progress economically for the rest of the decade, the Depression overwhelmed whatever relief Germany might have enjoyed. At the time of his death in 1929 Gustav Stresemann, the German foreign minister since August 1923, had been working with the Allies on replacing the Dawes Plan with the Young Plan. But, with a mounting propaganda campaign from the Nationalists, with Nazi support and the collapse of the government under the weight of reparations and the Depression, the plan collapsed. The policies of the government had driven up unemployment to a third of the work force, due in large part to efforts at reducing the trade deficit and government's deficits, in the hope that the Allies would relent on reparations. Felix argues, 'the Hoover Moratorium of July 1931 and the Lausanne Conference of June-July 1932 did, at last, permit reparations to disappear, but it was too late. The unemployment and despair had given Hitler 'the last materials he needed for gaining power., ${ }^{149}$

\subsubsection{The Debt Burden and Wealth Effects}

Despite the seemingly complex nature of the reparations issue, it was primarily the debtupon-deficit issue that lay at the heart of the Allies' inability to restore economic stability.

\footnotetext{
${ }^{148}$ Felix, (1971, p. 175).

${ }^{149}$ Felix, (1971, p. 176).
} 
Reparations grew out of a larger debt problem the countries of Europe faced at the conclusion of the war. Aside from the debts of the belligerent countries, the Allies faced significant indebtedness, commonly termed inter-Allied debt. The problem exercised policy-makers and journalists for the rest of the 1920s. Allied intergovernmental indebtedness stood at \$US16.4 billion at the Armistice. The European Allies, including Britain, were indebted to the United States to the tune of \$US 7 billion. Britain lent more to her European Allies than it had borrowed from the United States. While the Americans made new loans to Europe in 1918-20 inter-Allied debt soured relations between the United States and Europe until the 1930s. The European Allies argued they could not afford to repay the United States, and any attempt to do so would intensify the post-war financial crisis. Singleton maintains this was an exaggeration and the sum involved (\$US 7 billion), was small in relation to the sum demanded of Germany. ${ }^{150}$ European governments also offered to cancel all intra-European war debt, and treat Germany more leniently, if the US agreed to write off transatlantic debt. The United States did proclaim a three-year moratorium on interest charges in 1919, and later substantially scaled down demands for repayment. However, due to resistance from the United States Congress, the US would not cancel inter-Allied debt, as Keynes had urged them to do in Economic Consequences, and debt repayments only ceased during the Depression.

As has been highlighted, some remain critical of the United States for not being more generous in forgiving war debts but Singleton points out, the Americans were perfectly entitled to limit their post-war commitment to Europe and to capitalise on the weak bargaining positions of Britain and France. He argues that, 'perhaps they would have acted differently if they could have foreseen the events of the next two decades, but of course they could not. There was no precedent in 1919, but there would be one in $1945 .^{151}$ Furthermore, as has been argued, with most other economic issues of the post-

\footnotetext{
${ }^{150}$ Singleton, (2007, p. 35). Figures on inter-allied indebtedness have been taken from Singleton's synopsis.

${ }^{151}$ Singleton, (2007, p. 35).
} 
war period, reasons for failure, turmoil and lack of co-operation were complex and almost impossible to deal with on their own. Four years of war had unleashed powerful social forces and caused massive economic disruption. Empires had fallen with property rights in Russia overthrown. Money wages and benefits, but not real working class incomes, had risen substantially. After 1918 working class parties and the trade unions fought attempts to transfer some of the financial burden of the war away from the holders of paper assets and onto the working class sector. Maier argues this resistance was relatively successful and while capitalism survived, significant concessions were made to the working class in order to restore stability and safeguard the fundamental interests of property owners. ${ }^{152}$

The relative changes to the distribution of wealth in this period can be seen in the statistics. Between 1911-13 and 1924, the share of the richest 5 per cent of adults in the aggregate net marketable worth of England and Wales fell from 87 per cent to 81.5 per cent. The share of the poorest 60 per cent of taxpayer households in Germany's taxable income rose by 4.8 percentage points between 1913 and 1926, while the share of the top 10 per cent of households fell by 5.5 per cent. Earned income as a share of total income in Germany rose from 50 per cent to 65 per cent between 1913 and 1925. In France, dividends, interest and rent as a share of household primary income fell from 26.8 per cent in 1913 to 18.3 per cent in 1926 . The war and economic downturn in the early 1920s also tended to have an egalitarian impact in the United States. Singleton argues,

modern readers are likely to view the redistribution of income and wealth in a positive light. However, the process by which the financial burden of the war was reallocated was intensely disruptive to economic activity. Currencies rose and fell, savings were destroyed, businesses collapsed and millions of jobs were lost. Failure to resolve the distributional questions arising from the war was a major cause of uncertainty and instability within nations and internationally. ${ }^{153}$

\footnotetext{
${ }^{152}$ Maier, (1975).

${ }^{153}$ Singleton, (2007, p. 42).
} 


\subsection{Summary - The European Economy Post-World War One}

This chapter outlines the context of Keynes' book and the messages he sought to communicate. He saw the problems of the world as fundamentally economic ones and believed that if his contemporaries understood this there would be a will and determination to find solutions for returning the world to economic stability and prosperity.

In the fifty years leading up to World War One, Europe had experienced continual economic growth, stable monetary and trading conditions, and an economic system of laissez-faire that contributed to increasing prosperity. However, with the cessation of hostilities in 1918, Europe found it was not possible to return to pre-war economic conditions. The next decade was marked by dislocation, turmoil, and instability. The forces of globalisation that had delivered prosperity and economic convergence to Europe first, and then gradually to other parts of the world, also contained seeds of divergence which, as time went on, eroded the forces of convergence to the point where economically interdependent and integrated nations went to war with one another.

A combined result of war, population displacement, accumulating deficits and wealth re-distribution conspired to undermine attempts at restoring the industrial productivity levels to pre-war levels. Some 50-60 million people had either lost their lives or been displaced between 1914 and 1918. In addition, physical destruction had been acute in some countries. France emerged from the war almost bankrupt. Germany faced a nutrition crisis and significant decline in industrial capability. Russia had lost an empire and the loss of property rights. While Britain did not suffer direct physical destruction, it lost its place as the financial powerhouse behind world trade and prosperity, and was superseded by the United States as the leading global economic power. With the exception of the US and Japan, GDP levels in all countries did not recover their 1913 levels until at least 1924 and in many cases it took the full decade of the 1920s to reach pre-war levels, only to be pushed further back with the events of the Depression from 1929 to 1933. Furthermore, internal price stability had broken down by the end of the war. 
Countries found they could not return to the system of gold convertibility, and inflation, and in the case of Germany, hyperinflation, was difficult to control. Rising deficits, and declining investor confidence added to the risk of social collapse, which posed a threat to capitalism itself.

A lack of both economic leadership and co-operation added to the instability and led to international chaos, adding to the risks already faced by countries struggling with accumulated war debts, declining agriculture, and in some cases, a heavy burden of reconstruction. The Allies' failure to deal with the burden of inter-Allied debt typified the lack of leadership and co-operation. For the belligerents the issue of reparations, especially in the case of Germany, added to increasing frustration and resentment, which may have been overcome if all nations had been able to co-operate.

Globalisation as a force of divergence also typified the lack of co-operation as global rivalries, associated with fervent nationalism, failed to abate after the war. The United States retreated into isolationism, the Austro-Hungarian Empire disintegrated, only to be replaced by an economically unbalanced group of Central and Southern European nations, which in turn saw the decline of intra-regional trade. The Conference of Versailles had been designed to put Europe back onto a path of prosperity and a return to pre-war stability. Instead it was a continuation of war by peaceful means. The participants failed to address, and come to terms with, the accumulated debt and destruction of the war years. Of most significance was the failure, above all things, to address the urgent need for cooperation and economic leadership so desperately needed after the disaster of the war years. 


\section{Chapter 5. Keynes' Use of Statistics in The Economic Consequences of the Peace}

As has been argued, Keynes enjoyed success in communicating his ideas although many readers did not grasp the central argument of Economic Consequences. The next two chapters examines Keynes' claim the book was a serious work of economics. While he used a tightly integrated mix of prose and statistics it is difficult to appreciate how important Keynes' statistics were without separating and examining them in isolation from the prose. There is a danger that by doing this Keynes' style is overlooked; the more important because it was often his successful integration of prose, poetry and statistics, which explains his communication success. However, unless we examine Keynes' statistics in isolation it is difficult to appreciate how important they were as elements of his arguments. Furthermore we can better decide whether Keynes' claim Economic Consequences was a serious work of economics is correct by examining the numbers and statistics he used.

Many of the statistics in Economic Consequences came from Treasury memoranda. This helps explain the unsystematic presentation in places as memoranda normally follow more informal conventions of communication. However it also demonstrates Keynes had a rhetorical advantage by drawing on a trusted source and one least likely to be challenged. The veracity of his numbers and statistics were more likely to be accepted if they came from an official source. In comparison to reactions Keynes received to his prose, reaction to his numbers was relatively muted, an indication of critics' willingness to accept the authority of his statistics. Even when Mantoux, the first serious challenger of Keynes' numbers, published his critique 27 years after the publication of Economic Consequences, his criticisms were more to do with hindsight than focusing on the context of 1919. While such an approach adds to our knowledge of history it does little to explain why Keynes used the numbers he did and why they seemed to be accepted almost without challenge during the 1920s. 


\subsection{Statistics from Economic Consequences}

Provided in this section is a set of tables that lists all statistics and numbers, with supporting comments, that Keynes included in his book. Another way of viewing these tables is to see them as a presentation of Economic Consequences, with all prose not directly linked to Keynes' statistics and numbers, stripped out. There are disadvantages and advantages in this approach. Among the disadvantages is the danger that by focusing exclusively on Keynes' statistics and numbers we fail to comprehend the unique and rich style of the book.

However, the advantages of such an examination outweigh the disadvantages for a number of reasons. First, Keynes was adamant that Economic Consequences was a serious economic text, rather than a book of political propaganda. By taking away much of the prose, which can be judged as political, the numbers and statistics can be better analysed in economic terms. Second, statistics and numbers are often not associated with rhetoric and persuasion but rather are provided by economists in the belief numbers are more objective than discursive prose. There is also a view the use of numbers brings greater precision and clarity to an understanding of economic issues. For Keynes it was all about persuasion and he was just as likely to use statistics and numbers as prose in order to achieve his ends.

While the form of presentation below is not considered ideal, a number of approaches have been tried with this approach proving to be the most workable. The tables that follow immediately provide all the statistics, numbers and relevant explanations in the same sequence as they appear in Economic Consequences. It also needs to be noted that analysis is undertaken following some preliminary sections. 
Table 7: Europe before the War

\begin{tabular}{|c|c|c|}
\hline \multicolumn{3}{|c|}{ Chapter 2: Europe before the War } \\
\hline \multirow[t]{5}{*}{ p.10. } & Population & \\
\hline & 1870 Germany & $40 \mathrm{mill}$ \\
\hline & 1892 Germany & $50 \mathrm{mill}$ \\
\hline & June 1914 Germany & $68 \mathrm{mill}$ \\
\hline & Preceding war annual increase about 850,000 & \\
\hline \multirow[t]{2}{*}{ p. 11.} & 1890 Austro-Hungary & $40 \mathrm{mill}$ \\
\hline & 1914 Austro-Hungary & $50 \mathrm{mill}$ \\
\hline \multirow[t]{3}{*}{ p.12. } & 1890 Russia & $<100 \mathrm{mill}$ \\
\hline & 1914 Russia & $\sim 150 \mathrm{mill}$ \\
\hline & Births over deaths before war 2 mill per annum & \\
\hline \multirow[t]{8}{*}{ p. 14.} & Coal & Ton \\
\hline & 1871 Germany & $30 \mathrm{mill}$ \\
\hline & 1890 Germany & $70 \mathrm{mill}$ \\
\hline & 1900 Germany & $110 \mathrm{mill}$ \\
\hline & 1913 Germany & $190 \mathrm{mill}$ \\
\hline & Foreign Investment & \\
\hline & Germany pre-war & $f 1,250,000,000$ \\
\hline & $\begin{array}{l}\text { pounds } 500 \text { mill invested in Russia, Austro-Hungary, } \\
\text { Bulgaria, Roumania \& Turkey }\end{array}$ & \\
\hline
\end{tabular}

Page 196

8-Jun-11 


\section{Table 8: The Treaty, Shipping and Coal}

\begin{tabular}{|c|c|c|}
\hline \multicolumn{3}{|c|}{$\begin{array}{c}\text { Chapter 4: The Treaty } \\
\text { Shipping }\end{array}$} \\
\hline \multirow[t]{2}{*}{ p. 60} & Germany ceded to Allies all vessels & $>1600$ tons \\
\hline & ceded $1 / 2$ vessels between & $1000 \& 1600$ tons \\
\hline \multirow[b]{2}{*}{ p. 61} & \multicolumn{2}{|l|}{ ceded $1 / 4$ trawlers \& other fishing boats } \\
\hline & $\begin{array}{l}\text { For } 5 \text { years must build annually for allies ships up to } \\
\text { ceded all rights \& titles over overseas possessions, incl. debts }\end{array}$ & 200,000 tons \\
\hline & Coal & \\
\hline p. 71 & up to May 1,1921 demand payment in any form of pounds & $1000 \mathrm{mill}$ \\
\hline \multirow[t]{3}{*}{ p. 78} & of coal left to Germany, make good year by year not to exceed & $20 \mathrm{mill}$ \\
\hline & tons for first 5 years \& 8 mill tons in any one year of & \\
\hline & succeeding 5 years & \\
\hline \multirow[t]{5}{*}{ p. 80} & Deliver to: & \\
\hline & France 7 mill tons annually for 10 years & \\
\hline & Belgium 8 mill tons annually for 10 years & \\
\hline & \multirow{2}{*}{$\begin{array}{l}\text { Italy annual increments from } 4.5 \text { mill } 1919 / 20 \text { to } 8.5 \text { mill in each of } 6 \\
\text { years } 1923 / 24 \text { to } 1928 / 29 \text { Luxemburg. Ave. } 25 \text { mill tons }\end{array}$} & \\
\hline & & \\
\hline \multirow[t]{25}{*}{ p. 81} & Germanys output in 1913 & 191.5 tons \\
\hline & of this 19 mill consumed at mine & \\
\hline & 33.5 mill exported & \\
\hline & Leaves 139 mill for domestic consumption & \\
\hline & Used as follows Railways & $18 \mathrm{mill}$ ton \\
\hline & Gas, water, electricity & 12.5 mill ton \\
\hline & Bunkers & $6.5 \mathrm{mill}$ ton \\
\hline & House-fuel, small industry \& agriculture & 25 mill ton \\
\hline & Industry & $78 \mathrm{mill}$ ton \\
\hline & total & 139 mill ton \\
\hline & \multicolumn{2}{|l|}{ Production lost from following territory: } \\
\hline & Alsace-Lorraine & $3.8 \mathrm{mill}$ ton \\
\hline & Saar Basin & 13.2 mill ton \\
\hline & Upper Silesia & $43.8 \mathrm{mill}$ ton \\
\hline & total & $60.8 \mathrm{mill}$ ton \\
\hline & Based on 1913 level. 130.7 mill ton left, but deducting consumption & \\
\hline & at mines, $\quad 118$ mill tons left & \\
\hline & of this, 20 mill to France for loss of French mines & \\
\hline & 25 mill to France, Belgium, Italy \& Luxemburg (say 40 mill to Allies) & \\
\hline & Leaves 78 mill for own use against pre-war consumption of & \\
\hline & 139 mill. tons & \\
\hline & But 1918 production & 161.5 mill ton \\
\hline & vs 1913 production of & 191.5 mill ton \\
\hline & First $1 / 2$ of $1919<50 \mathrm{mill}$ tons exclusive of Alsace-Lorraine $\&$ the & \\
\hline & Saar but incl. Upper Silesia, annual production 100 mill. & \\
\hline p. 83 & Of the $\mathbf{1 1 8}$ mill likely to fall as low as & 100 mill ton \\
\hline & If 40 mill exported to Allies, remains 60 mill for Germany & \\
\hline p. 84 & Demand \& supply will diminish by loss of territory but no more than & \\
\hline & 29 mill. Therefore, post-war reqs (on pre-war efficiencies) & \\
\hline & 110 mill tons against output $<100$ mill of 40 mill goes to Allies & \\
\hline p. 86 & July 1919 Hoover estimates coal output of Europe (excl. Russia \& & \\
\hline & Balkans) dropped from 679.5 mill to 443 mill tons. & \\
\hline
\end{tabular}

Page 197

8-Jun-11 
Table 9: Reparations, Belgium and French Claims

\begin{tabular}{|c|c|c|}
\hline \multicolumn{3}{|c|}{ Chapter 5: Reparations } \\
\hline \multirow[t]{8}{*}{ p. 113} & Belgium Claims & \\
\hline & Wealth 1913: Land & $f 264,000,000$ \\
\hline & Buildings & $f 235,000,000$ \\
\hline & Personal & $f 545,000,000$ \\
\hline & Cash & $£ 17,000,000$ \\
\hline & Furniture etc & $£ 120,000,000$ \\
\hline & Total & $\underline{£ 1,181,000,000}$ \\
\hline & Per inhabitant & f156 \\
\hline \multirow[t]{8}{*}{ p. 114} & Holland & f167 \\
\hline & Germany & f244 \\
\hline & France & $f 303$ \\
\hline & A total of: $1,500,000,000$ (pounds) or per head ave. & f200.00 \\
\hline & Actual physical loss by destruction \& looting & $f 150,000,000$ \\
\hline & Levies, fines, requisitions & $f 100,000,000$ \\
\hline & Advanced to Belgium by her Allies, add a further & $f 250,000,000$ \\
\hline & Total & $f 500,000,000$ \\
\hline \multirow[t]{17}{*}{ p. 116} & French Claims & \\
\hline & Not above $10 \%$ of France occupied, and not $4 \%$ lay within area of substantial & \\
\hline & devastation. Of the 60 French towns with population exceeding 35,000 , & \\
\hline & only 2 destroyed (Reims 115,178 \& St. Quentin 55,571 ) & \\
\hline & 3 others occupied, Lille, Roubaix \& Douai. Amiens, Calais, Dunkerque \& Boulogne & \\
\hline & suffered secondary damage from air bombing. & \\
\hline & But offset was new works by the British army. & \\
\hline & 1917 value of house property & $f 2,380,000,000$ \\
\hline & Wide of the mark is the current estimate (1919) of damage of & $f 800,000,000$ \\
\hline & More accurate figures would be at pre-war prices & $£ 120,000,000$ \\
\hline & or say at present time & $£ 250,000,000$ \\
\hline & Est. land value (excl. buildings) vary from & $f 2,480,000,000$ \\
\hline & to & $f 3,116,000,000$ \\
\hline & Therefore extravagant to put damage at & $£ 100,000,000$ \\
\hline & Farm capital for whole of France not put above & $£ 420,000,000$ \\
\hline & For physical and material damage difficult to establish a bill above & $f 500,000,000$ \\
\hline & in occupied and devastated area. & \\
\hline \multirow[t]{8}{*}{ p. 118} & Rene Pupin (French authority) puts total material losses between & $f 400,000,000$ \\
\hline & and & $f 600,000,000$ \\
\hline & However M. Dubois (on behalf of the Budget Commission) & \\
\hline & gives a figure of & $f 2,600,000,000$ \\
\hline & $\begin{array}{l}\text { this is a min. as it excludes war levies, losses at sea, the roads, or loss of } \\
\text { public monuments }\end{array}$ & \\
\hline & But M. Louceur (Minister of Industrial Reconstruction) stated reconstitution in & \\
\hline & devastated areas at: & $f 3,000,000,000$ \\
\hline & $\begin{array}{l}\text { Other French claims incl. levies \& requisitions on occupied areas, losses of French } \\
\text { mercantile from German attacks }\end{array}$ & \\
\hline \multirow[t]{3}{*}{ p. 119} & To cover all claims, probably: & $f 200,000,000$ \\
\hline & but, to be on safe side, let's say: & $f 300,000,000$ \\
\hline & Total French claims should then be: & $f 800,000,000$ \\
\hline p. 120 & Klotz (Sep. 5, 1919) stated claim at & $£ 5,360,000,000$ \\
\hline
\end{tabular}

Page 198

8-Jun-11 


\section{Table 10: Reparations; British and Other Country Claims; Summary of Claims}

\begin{tabular}{|c|c|c|}
\hline \multicolumn{3}{|c|}{ Chapter 5: Reparations } \\
\hline \multirow{11}{*}{ p. 121} & British Claims & \\
\hline & $\begin{array}{l}\text { British claims limited to losses by sea and damage to civilian property } \\
\text { from air raid. }\end{array}$ & \\
\hline & Probably & $f 5,000,000$ \\
\hline & no more than & $f 10,000,000$ \\
\hline & Mercantile vessels lost $=2479$, aggregate $7,759,090$ tons gross & \\
\hline & Difference of opinion on replacement cost but at per gross ton & f30 \\
\hline & aggregate claim & $f 230,000,000$ \\
\hline & Add loss of cargoes (guesswork) @ pounds 40 per ton plus & $f 310,000,000$ \\
\hline & Total claim & $f 540,000,000$ \\
\hline & Add air raids, bombardments, interned citizens \& misc & $£ 30,000,000$ \\
\hline & Total British claim & $£ 570,000,000$ \\
\hline \multirow{15}{*}{ p. 122} & Other Countries Claims & \\
\hline & Italy's losses by invasion and at sea & $f 50,000,000$ \\
\hline & no more than & $f 100,000,000$ \\
\hline & Serbia national wealth & $£ 480,000,000$ \\
\hline & or per person & $\mathrm{f} 105$ \\
\hline & But all other countries together & $£ 250,000,000$ \\
\hline & Summary of Claims & \\
\hline & Belgium & $f 500,000,000$ \\
\hline & France & $f 800,000,000$ \\
\hline & Britain & $£ 570,000,000$ \\
\hline & Other Allies & $£ 250,000,000$ \\
\hline & Total & $f 2,120,000,000$ \\
\hline & Claims based on interpretation of pre-Armistace engagements $>$ & $f 1,600,000,000$ \\
\hline & but $<$ & $f 3,000,000,000$ \\
\hline & Should have asked for a final settlement of & $£ 2,000,000,000$ \\
\hline
\end{tabular}


Table 11: Reparations; the Conference and Treaty Terms

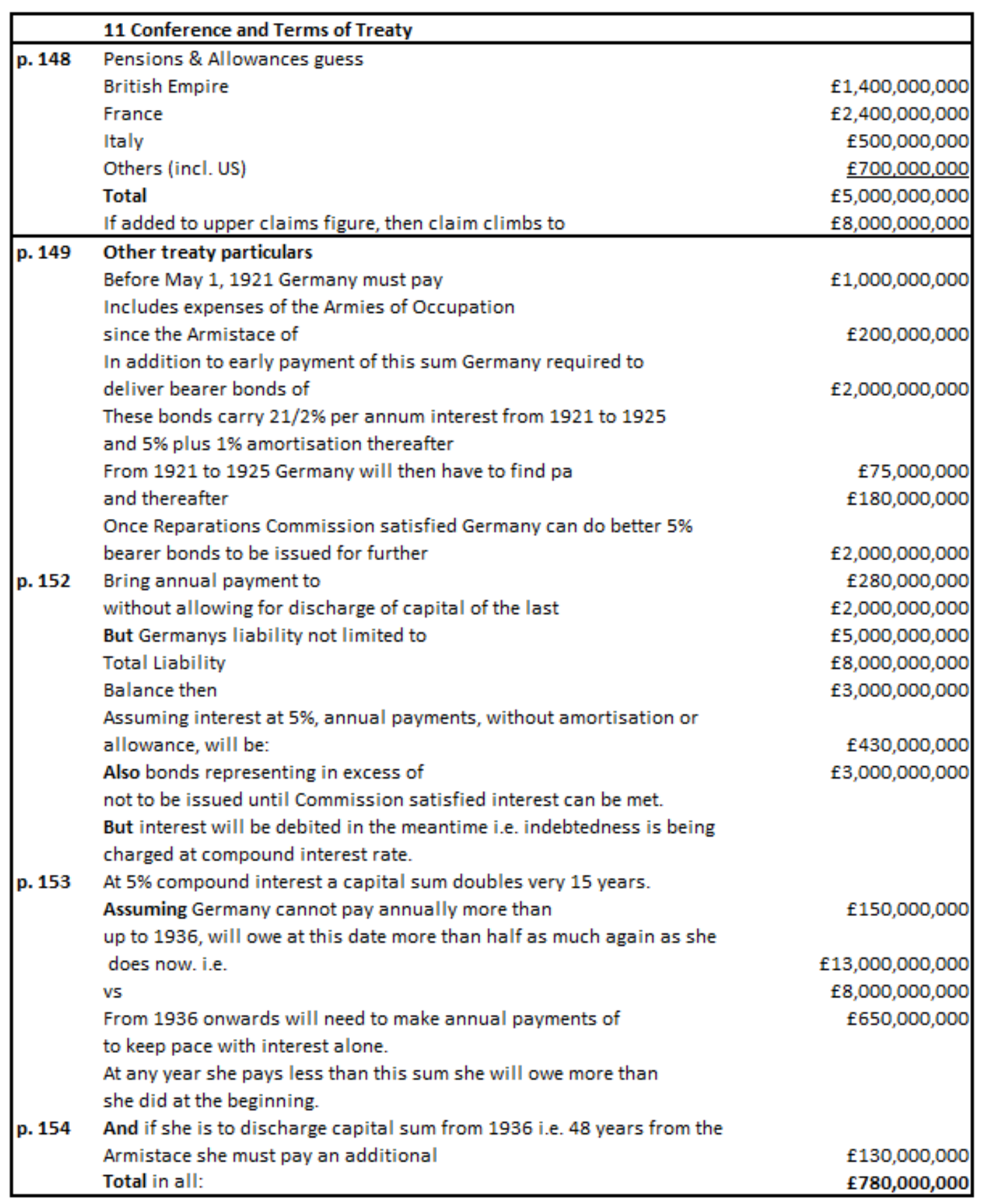

Page 200

8-Jun-11 


\section{Table 12: Reparations; Germany's Capacity to Pay; Immediately Transferable Wealth}

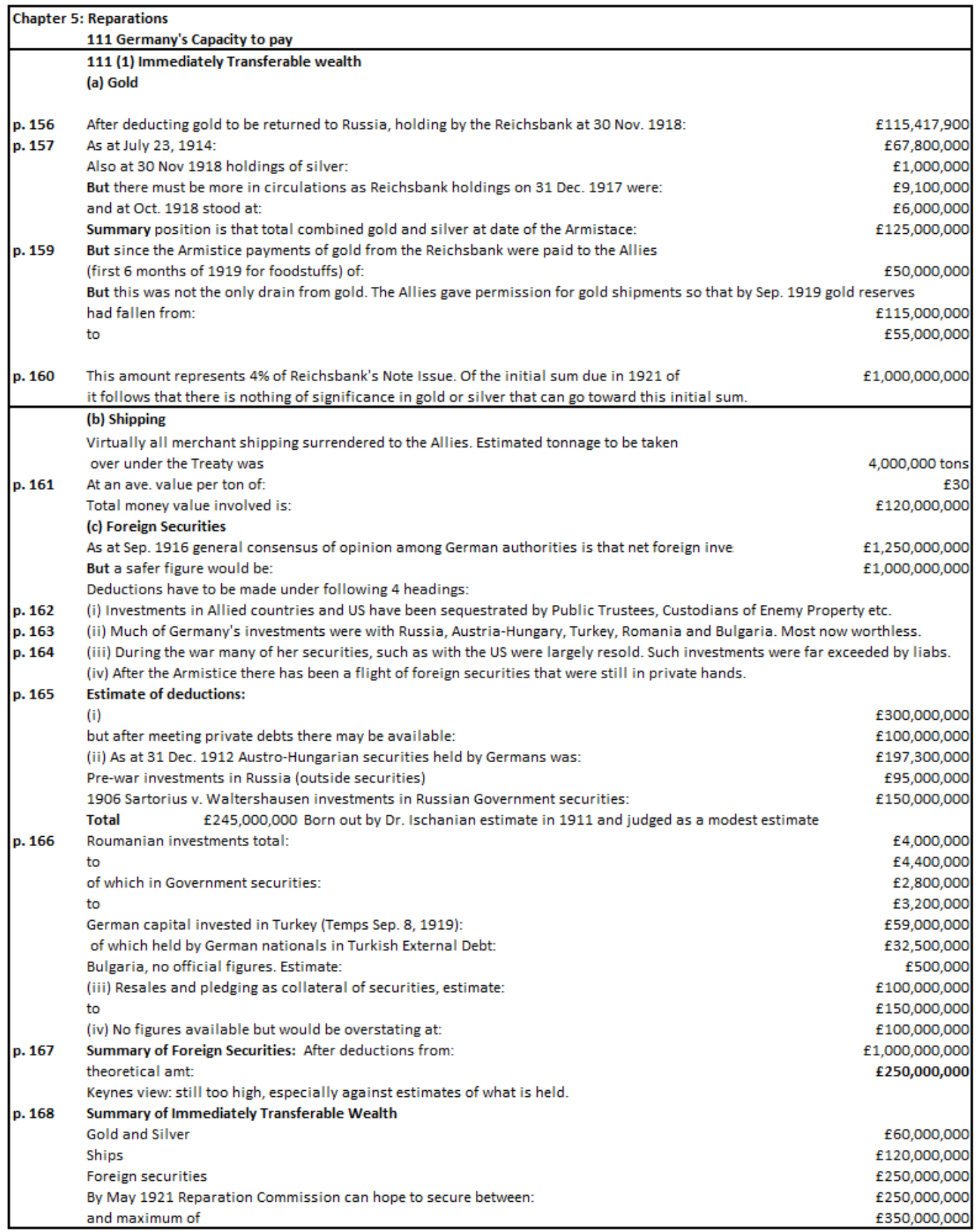

Page 201 


\section{Table 13: Reparations; Germany's Capacity to Pay; Property in ceded Territories or surrended under the Armistice}

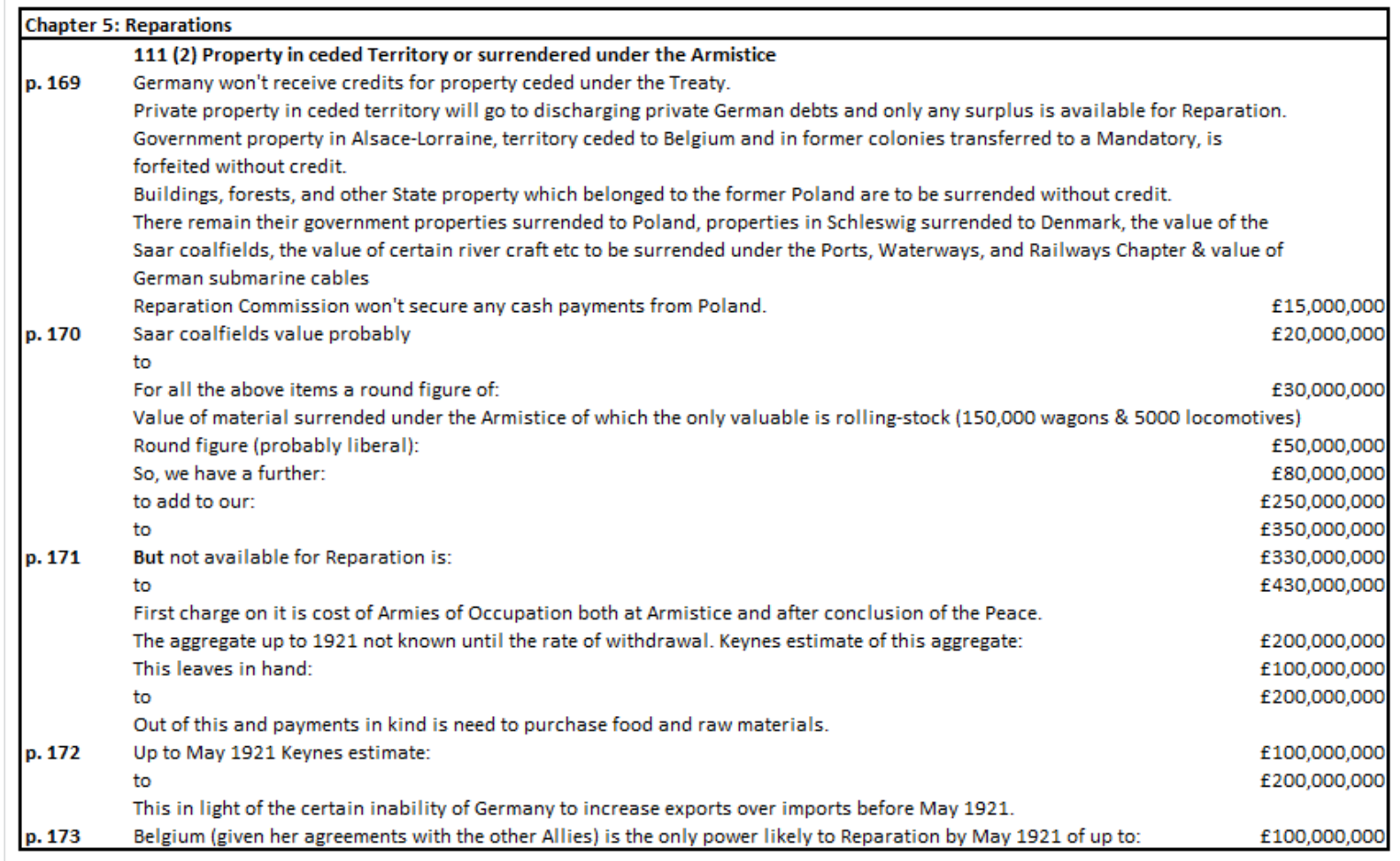




\section{Table 14: Reparations; Germany's Capacity to Pay; Annual Payments spread over Ten Years}

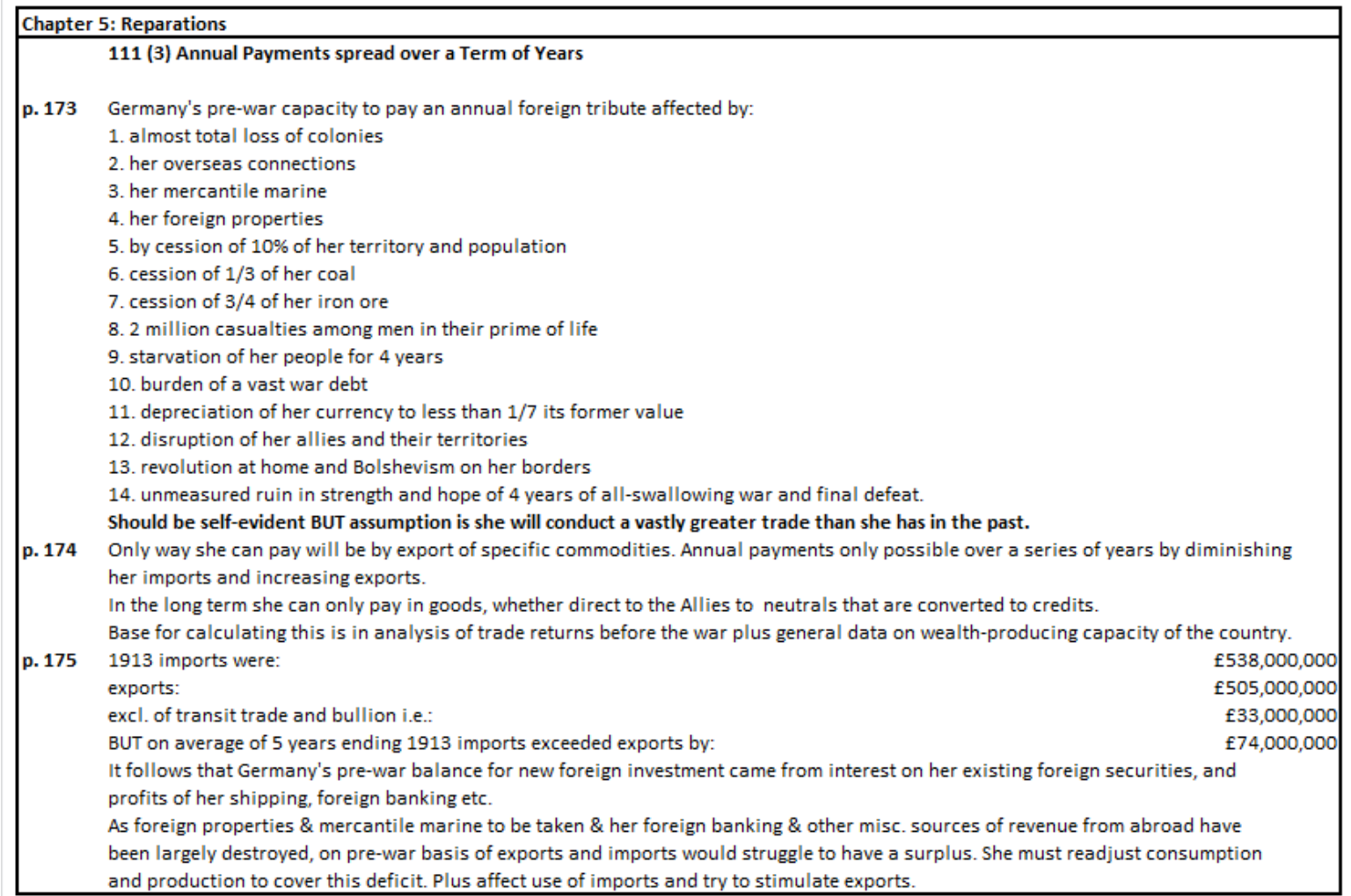




\section{Table 15: Reparations; Germany's Capacity to Pay; Annual Payments spread over ten years; Exports and Imports}

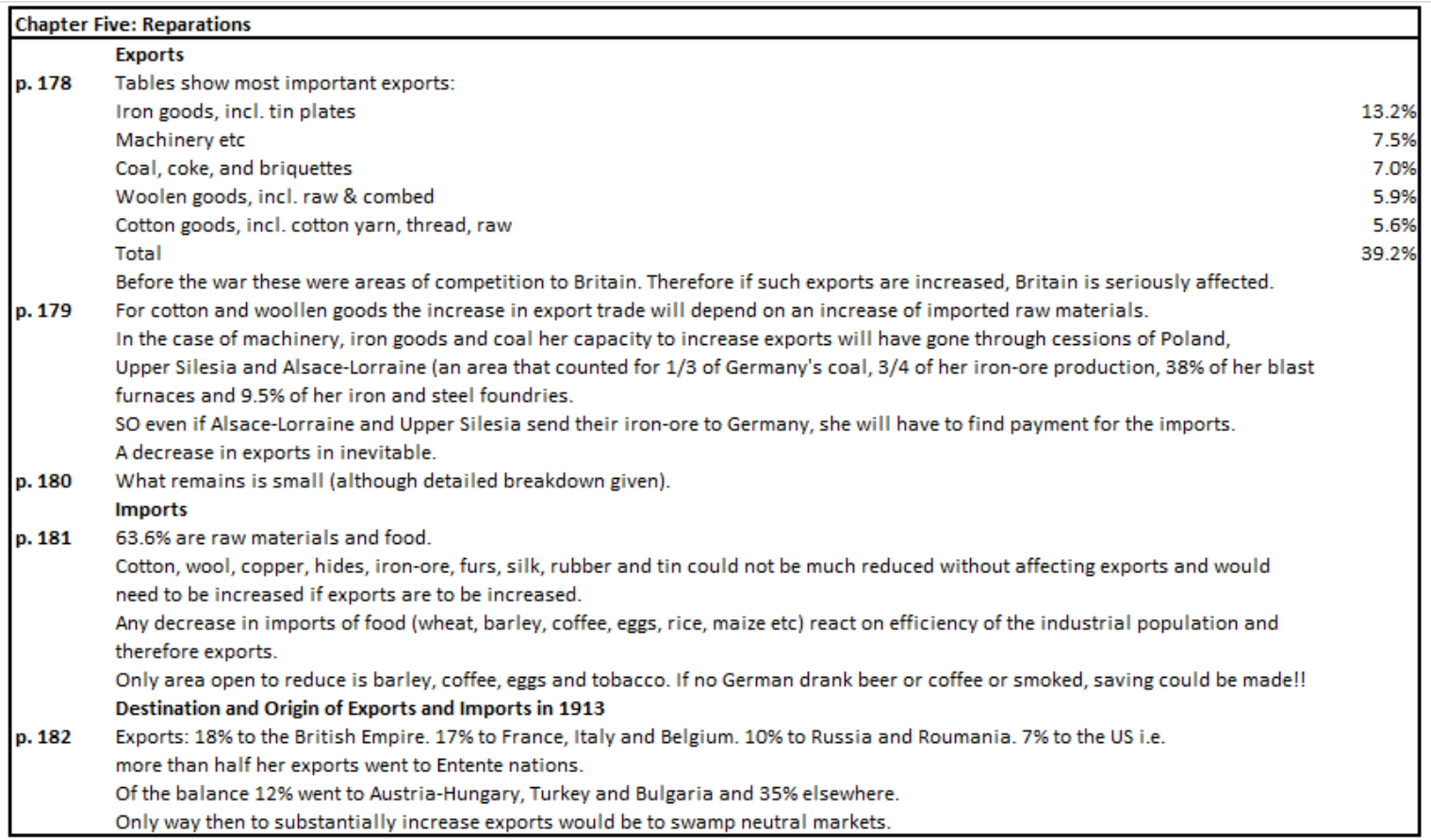




\section{Table 16: Reparations; Germany's Capacity to Pay; Annual Payments spread over Ten Years; Summary}

\begin{tabular}{|c|c|c|}
\hline \multicolumn{3}{|c|}{ Chapter Five: Reparations } \\
\hline & Summary & \\
\hline \multirow[t]{9}{*}{ p. 184} & 1. Iron goods. In light of loss of resources, decrease in exports more likely. & \\
\hline & 2. Machinery. Some increase possible. & \\
\hline & 3. Coal and coke. Value of net exports before the war: & $f 22,000,000$ \\
\hline & Allies have agreed that $20,000,000$ tons is max. possible export with (an impossible) increase to $40,000,000$ in the future. & \\
\hline & Measured in pre-war prices there is a decrease in export of manufactured articles. & \\
\hline & 4. Woollen goods. Increase not possible without raw wool, and there are other claims on wool. & \\
\hline & 5. Cotton goods. Same as for wool. & \\
\hline & 6. Cereals. Never will be a net export. & \\
\hline & 7. Leather goods. Same as for wool. & \\
\hline \multirow[t]{6}{*}{ p. 185} & These represent $1 / 2$ of Germany's pre-war exports. No other commodity represents as much as $3 \%$ of her exports. & \\
\hline & So in what does she pay? Dyes? Total value in 1913: & $f 10,000,000$ \\
\hline & Toys? Potash? 1913 & $\mathrm{f} 3,000,000$ \\
\hline & And even if commodities can be specified, to whom does she sell? Bearing in mind we are looking at hundreds of millions. & \\
\hline & On imports can do more. Lower standard of life but for many large items a reduction means a reduction of exports. & \\
\hline & A hypothetical example & \\
\hline \multirow[t]{15}{*}{ p. 186} & Let's look at improving trade balance annually by: & $f 100,000,000$ \\
\hline & Need this to liquidate adverse trade balance which before the war was: & $f 74,000,000$ \\
\hline & But. Let's assume that after this she is left with a trade balance per year of: & $f 50,000,000$ \\
\hline & Double this to allow for rise in pre-war prices, we have: & $f 100,000,000$ \\
\hline & Taking account of political, social, human and economic factors, doubtful she could be made to pay this annually over 30 ye & \\
\hline & BUT would not be foolish to assert or hope that she could. & \\
\hline & Allow $5 \%$ interest and $1 \%$ for repayment of capital, represents a capital sum of: & $\mathrm{f} 1,700,000,000$ \\
\hline & Conclusion: safe max. of capacity to pay. & $f 2,000,000,000$ \\
\hline & A Comparative example & \\
\hline & The wealth of France in 1871 was estimated at less than half of Germany in 1913. & \\
\hline & Aside from the changes in the value of money, an indemnity to Germany comparable to the 1871 French payment of: & $f 500,000,000$ \\
\hline & As the real burden of indemnity increases in proportion to its amount by Germany: & $f 2,000,000,000$ \\
\hline & would have far severer consequences than that paid by France in 1871 of : & $f 200,000,000$ \\
\hline & Only way would be to transport German workers to areas needing reconstruction but even then hard to see imported labour & \\
\hline & (over a number of years) having a net present value exceeding: & $f 250,000,000$ \\
\hline \multirow[t]{2}{*}{ p. 187} & A capacity of: & $f 8,000,000,000$ \\
\hline & but is not even reasonable at: & $£ 5,000,000,000$ \\
\hline
\end{tabular}




\section{Table 17: Reparations; Germany's Capacity to Pay; Annual Payments spread over Ten Years; Proviso's}

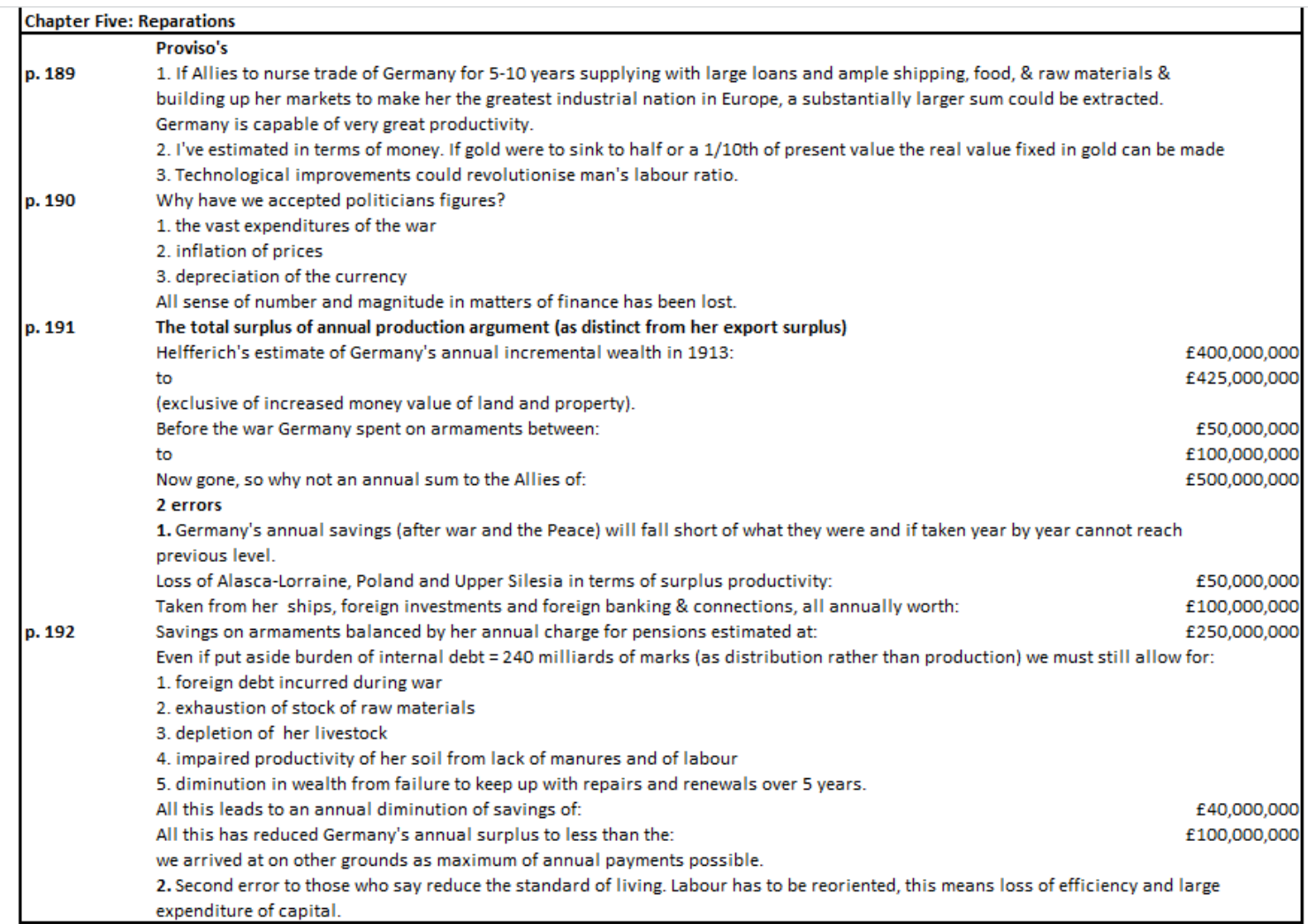




\section{Table 18: The Reparation Commission and the German Counter-Proposals}

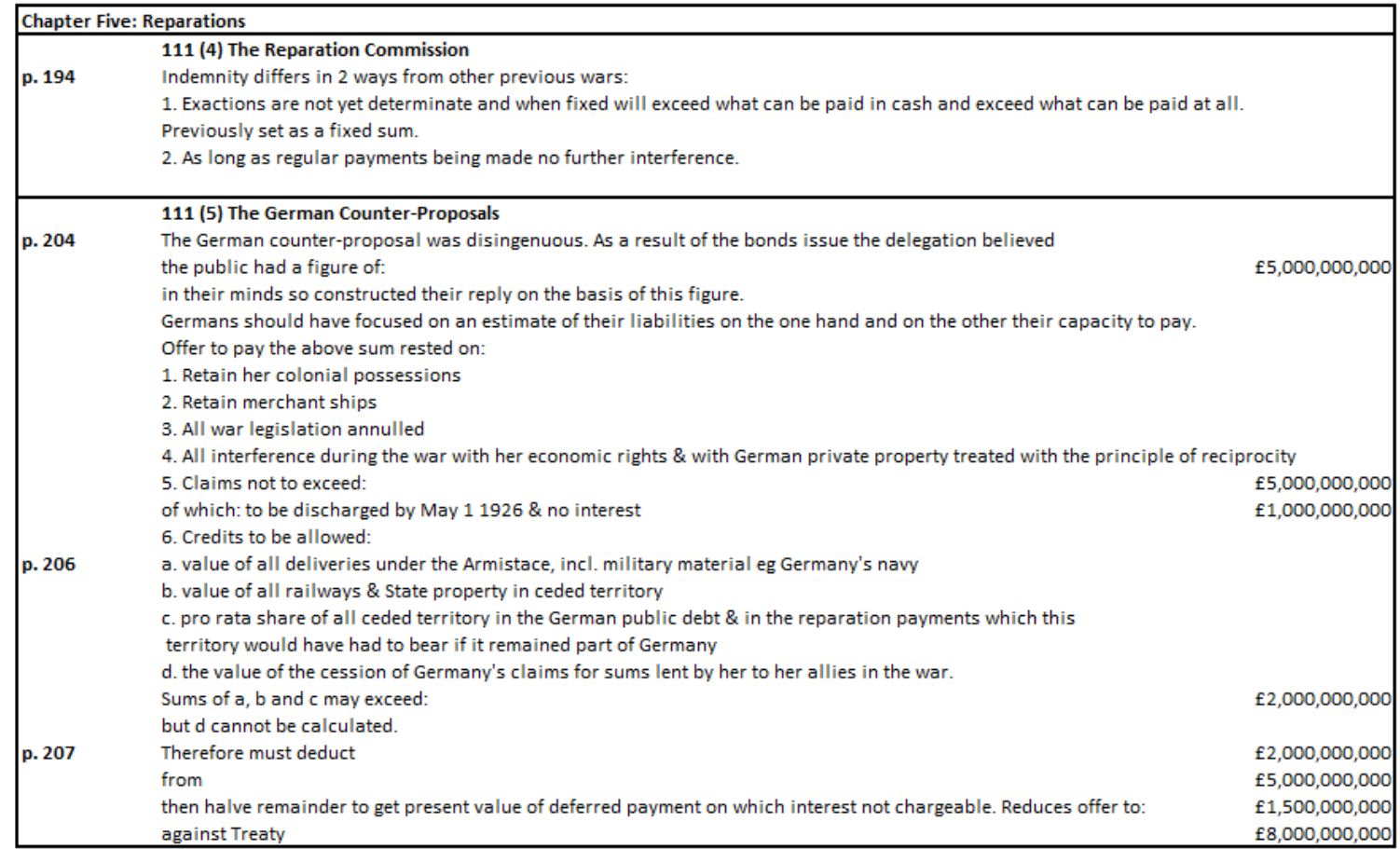

Page 207

8-Jun-11 


\section{Table 19: Europe after the Treaty}

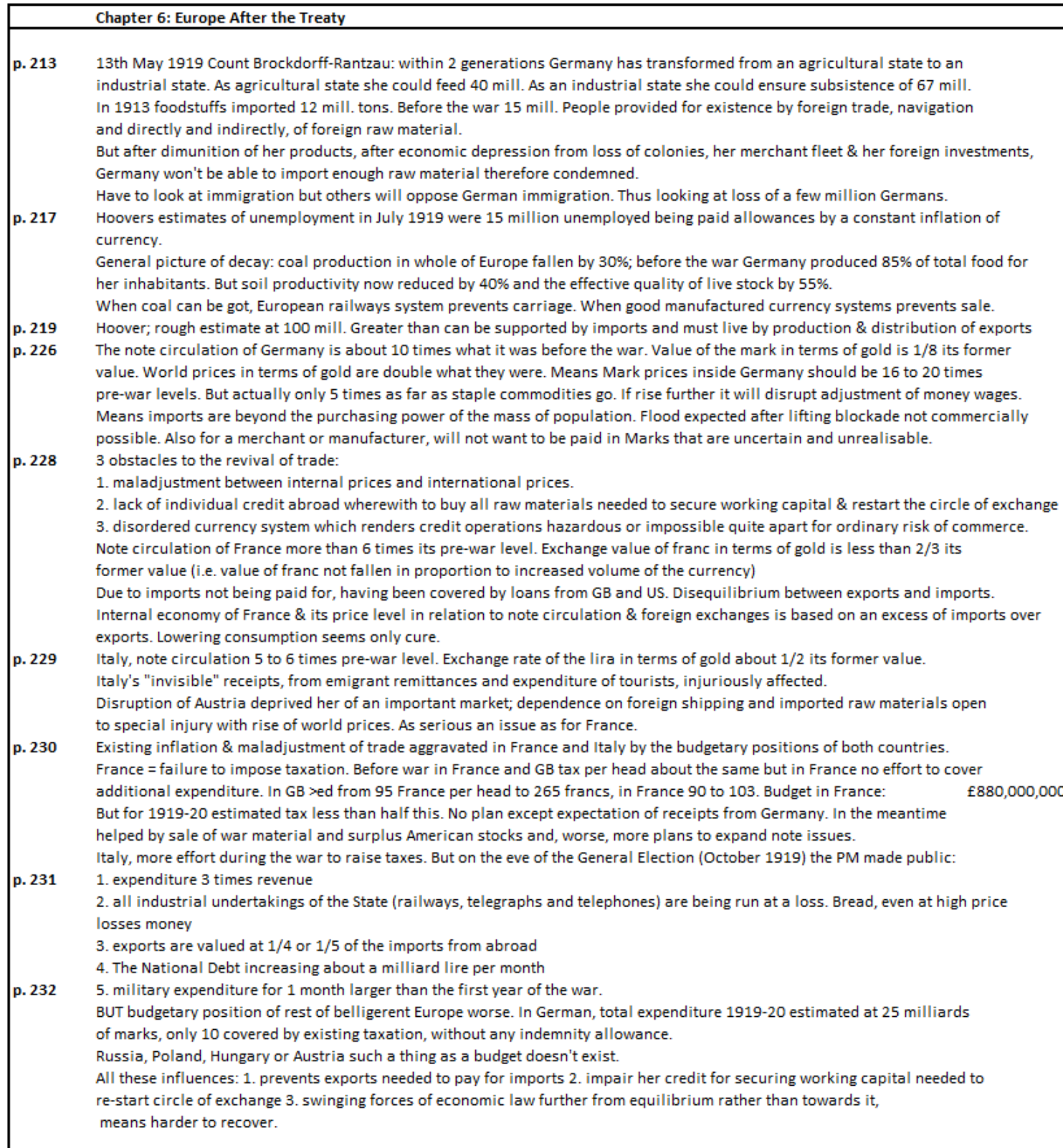

Page 208 


\section{Table 20: Remedies: The Revision of the Treaty Remedies}

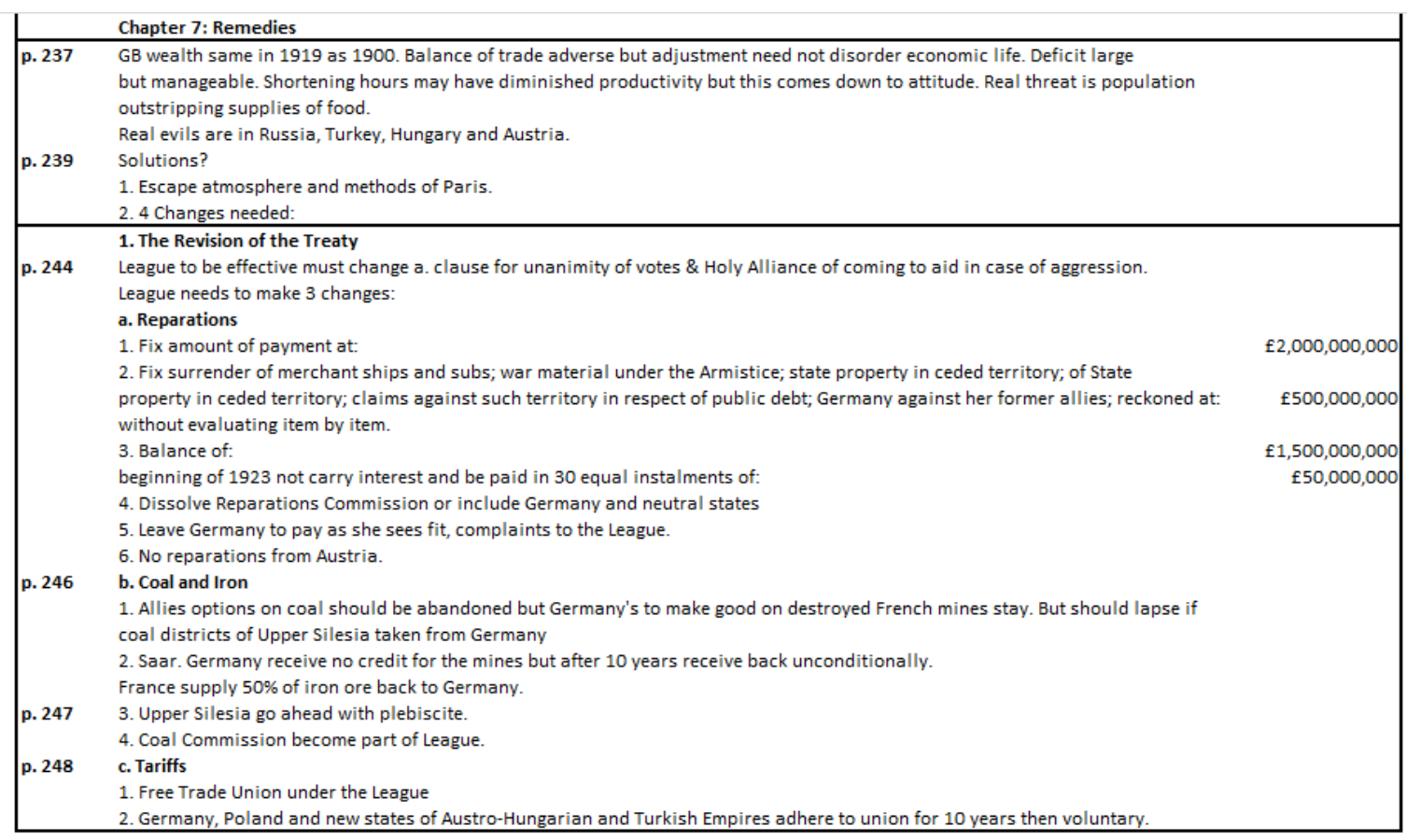


Table 21: Remedies; Settlement of Inter-Ally Indebtedness

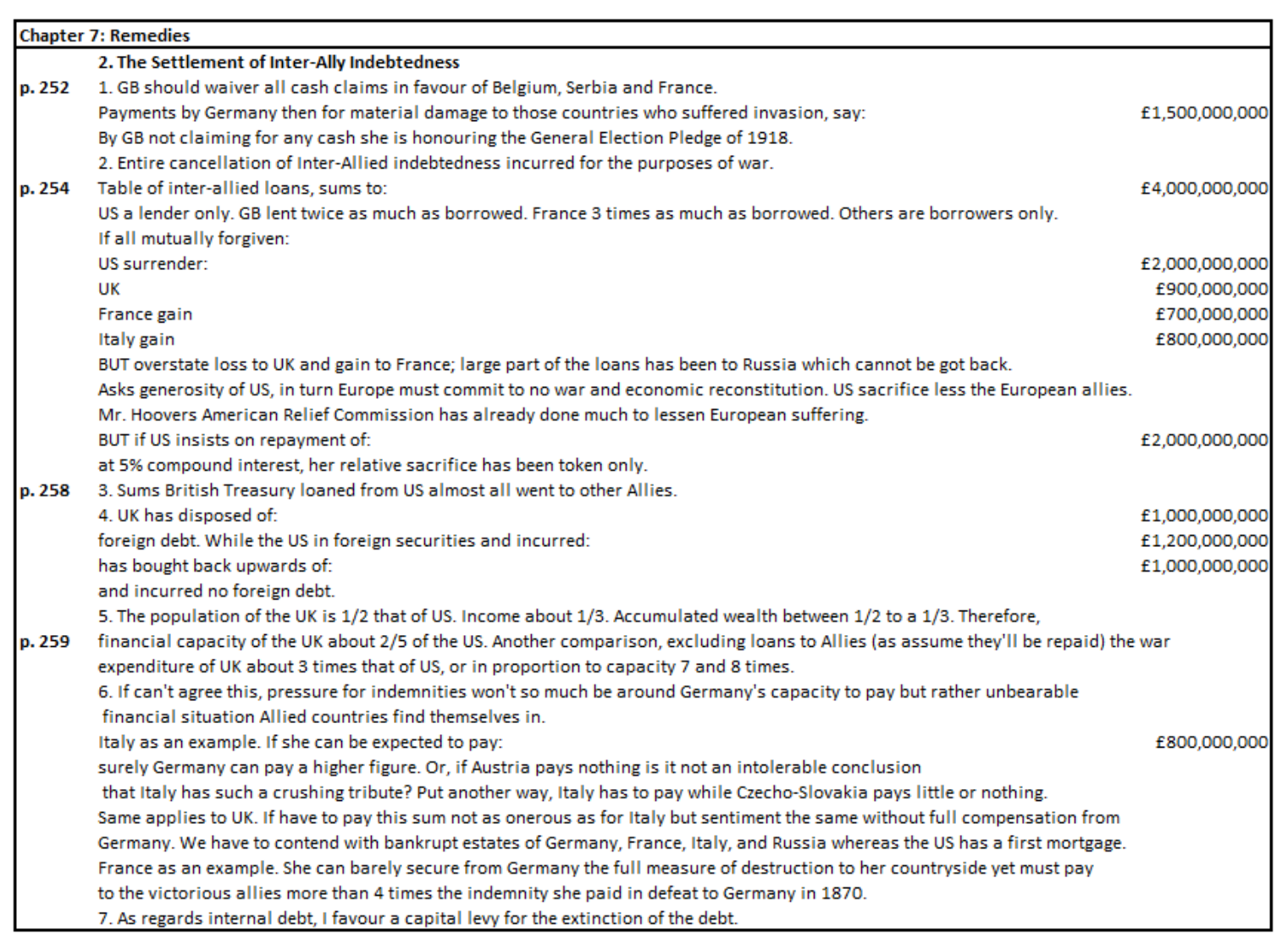

Page 210

8-Jun-11 
Table 22: Remedies; International Loan and Russia

\begin{tabular}{|l}
\hline Chapter 7: Remedies \\
\hline p. 265 3. An International Loan \\
Ills of the present: \\
1. Excess of Europe's imports over exports \\
2. adverse exchange \\
3. disorder of the currency. \\
Difficult to get European production going again without external assistance. \\
Advocate an international loan, the burden of which will fall on the US. \\
US objections: \\
1. Disentangle herself from Europe. \\
2. No guarantee Europe will put money to good use, probably squander it or a \\
Klotz will put off a little longer the need to raise taxes, Italy and JugoSlavia will fight for the proceeds, \\
Poland take on a military role and governing classes of Roumania divide the proceeds among themselves. \\
BUT all this aside, a fund of: \\
which carries a guarantee of repayment. \\
A further \\
could be used to reorganise the currency. \\
4. The Relations of Central Europe to Russia \\
Europe will need Russian wheat again in 1920-21. Current blockade is hurting us more than Russia. \\
Germany is best placed to help Russia recover her export trade.
\end{tabular}

Page 211

8-Jun-11 


\subsection{Rhetoric and Keynes' Statistics}

Keynes needed to persuade and convince his readers his statistics were legitimate if his claim that Economic Consequences was to be a serious work of economics was credible. The best evidence he succeeded is, whereas Keynes is often criticised for his rhetorical prose, few mount a similar challenge to the credibility of his statistics. For example, Keynes used numerous sets of statistics to support his argument the Treaty and its Reparations clauses (refer Tables 8 to 18 above), as proposed at the Conference of Versailles, would place an excessive burden on Germany, destroying not only German industry but putting at risk the economies of all European nations. Keynes makes the claim, 'the statistics of economic interdependence of Germany and her neighbours' are overwhelming. ${ }^{1}$ This was just one of many statistical claims not contested by his contemporaries.

According to Keynes economic interdependence came down to three parts of the economy that really mattered: food, coal, and transport. Table 8 lists the statistics for coal, taken from the Treaty, and used by Keynes to claim that the fatal consequences of the Treaty, should its terms be imposed, were economic. While food and transport were just as important economically for Europe, coal was a pivotal economic resource in postwar Europe, as it provided energy for industrial purposes and private consumption. Keynes argued, 'the German Empire has been built more truly on coal and iron than on blood and iron.'2 Any adverse impact on supply directly affected economic growth and development potential, in addition to meaning individual deprivation. Furthermore, when considering the example of coal Keynes was interested in the rhetorical use of statistics in two ways: first were statements given as facts and then suggested consequences. The facts for Keynes were, the coal mines in the Saar Basin were to be ceded to France

\footnotetext{
${ }^{1}$ Keynes, (1919, p. 14).

${ }^{2}$ Keynes, (1919, pp. 74-75).
} 
absolutely (refer the Treaty); the Saar district, Keynes points out, had been part of Germany for 1000 years (he assumed this to be common knowledge); Upper Silesia had $23 \%$ of the total German output of hard coal (from German statistical sources), yet would be, following a plebiscite, ceded to Poland (refer the Treaty). But, argued Keynes, Upper Silesia had never been part of Poland and 'economically' was 'intensely' German (his source here was from a German representative at the Conference). Out of the coal that would remain to her, Germany was obligated to make good year by year the estimated loss, which France had incurred by the damage and destruction in the coalfields of her northern provinces (again, from the Treaty). Sums due for Reparation were to be partly paid in kind rather than cash. To a number of Allied countries Germany was to provide $40,000,000$ tons, leaving $60,000,000$ tons against a pre-war consumption of $139,000,000$ tons (the Treaty). For example, a number of other Treaty provisions would add to this burden daily shifts were to be reduced from 8.5 to 7 hours (the Treaty).

Having given the reader a set of statements presented as facts, Keynes then painted his picture of consequences. The mining plant, due to the Allied blockade, is in bad condition; the physical efficiency of the men impaired by malnutrition, 'made worse by a lowered standard of living because of the reparation demands;' and one of the casualties of war was diminution of the number of efficient mines. Taken together Keynes argued that only $60,000,000$ tons of coal would be left for local consumption, based on the hypothetical calculation of there being only $100,000,000$ tons available per annum, of which 40,000,000 were to be mortgaged to the Allies. Added to the likelihood German industry would be destroyed as a result of these terms, the situation in other countries would only add to a burden for all European nations. France's own output had diminished through the war's destruction. In the UK and Italy a secondary cause of inadequate coal supplies to enable industry to recover and provide for the population was organisational 
breakdown and inefficiencies of new governments. Keynes argued, 'the coal position of all Europe [was] nearly desperate.'3

These statistics are an example of how Keynes used numbers that seemed "factual, objective, and neutral" and would be difficult to refute. In other words, if the Treaty says it, this makes it factual. He then moved on to describing the consequences revealed by these statistics in a way that, again, would be difficult to contest. They were officially documented consequences from the conference proceedings, which had the effect of making them factual.

Writing twenty five years after the publication of Economic Consequences Mantoux challenged many of the statistics Keynes had used, arguing that contrary to Keynes' own assessment of the 'general accuracy' of his figures, they were anything but accurate and, according to Mantoux, Keynes had used statistics in a way that were either out of context or deliberately exaggerated so as to persuade his readers the central arguments of Economic Consequences were supported by the authority of statistics. To the present day there are divergent opinions as to which numbers, Keynes' or Mantoux's, better represent what was taking place in 1919. That is to say, can we rely more on Keynes' numbers because he understood the context from which he sourced many of them? Or, does additional knowledge gained from hindsight mean Mantoux was able to better judge the veracity of the numbers Keynes used? Whoever we choose to agree with, this debate supports McCloskey's argument that economists use numbers rhetorically arguing that 'the economic conversation has heard much eloquent talk, but its most eloquent passages have been mathematical. ${ }^{4}$ It is almost impossible to make a reasoned judgment on the 'accuracy' of the statistics used by Keynes or Mantoux, such are the difficulties associated with source accuracy, methodologies used to arrive at the numbers, the actual relevance

\footnotetext{
${ }^{3}$ Keynes, (1919, pp. 75-85).

${ }^{4}$ McCloskey, (1986, p 3).
} 
of the statistics to the argument being made and how Keynes or Mantoux might have subtly chosen one set of numbers over another in order to strengthen their respective arguments.

In reality both Keynes and Mantoux use statistics to, in McCloskey's words, 'make conversation.' In McCloskey's terminology both men did not use statistics to deal with truth directly. Furthermore, while Mantoux disputed many of Keynes' numbers he acknowledged that Economic Consequences had been most successful in persuading public opinion as to the veracity of Keynes' economic conclusions. Mantoux cites Winston Churchill who wrote in 1929, 'Mr. Keynes, a man of clairvoyant intelligence and no undue patriotic bias [was] saturated in the Treasury knowledge of the real facts [and] revolted against the absurd objectives which had been proclaimed, and still more against the execrable methods by which they were achieved. [Keynes] showed in successive chapters of unanswerable good sense the monstrous character of the financial and economic clauses. On all these matters his opinion is good. ${ }^{5}$

${ }^{5}$ Churchill, (2007, p. 115) from Mantoux, (1946. p. 12). 


\subsection{Present-Day Assessments of Keynes' Use of Statistics in Economic Consequences}

During the last few decades economists have tended toward the view Keynes exaggerated both his argument concerning Germany's capacity to pay and the figures he used to support those arguments, which are presented in Section 5.1. above. However, many of these arguments suffer the same fate as Mantoux's analysis; while it is easy with hindsight to point out where Keynes was wrong, few have successfully challenged the statistics Keynes used from within the context of 1919. For example, as has been stated, Singleton argues it was doubtful the Allies ever expected Germany to pay more than the first 50 billion gold marks of the 132 billion gold marks handed down in the 1921 London Schedule of Payments. But, this judgment has the benefit of hindsight; there is no explicit archival evidence to substantiate the claim this is what the Allies intended in $1921{ }^{6}$

Ferguson also argues Keynes' arguments and figures were exaggerated and to make his point he makes four statistical comparisons between Britain and Germany of events that followed the war. However, it is not clear why Ferguson chooses these particular figures in preference to others as they really say nothing about his central claim of exaggeration. In the first example, he contends that some 2.4 million British workers were involved in strikes in 1919, 300,000 more than in revolutionary Germany. Second, in 192186 million days were lost in industrial disputes; the German figure was 22.6 million. Ferguson's third example is an electoral increase from 7.7 million to 21.4 million by the 1918 Representation of the People Act, more or less giving Britain the franchise Germans had enjoyed since 1871 (universal male suffrage). In the final example, only in the inflationary stakes did Germany fare worse, having run completely out of control, so that the Reichsmark was worth virtually nothing by the end of $1923 .{ }^{7}$ In reality, argues

\footnotetext{
${ }^{6}$ Singleton, (2007, p. 33).

${ }^{7}$ Ferguson, (1999, p. 396).
} 
Ferguson, the peace terms were not unprecedented in their harshness and the German hyperinflation was mainly due to the irresponsible fiscal and monetary policies adopted by the Germans themselves. Ferguson believes the Germans thought they could win the peace by economic means and points out they were more successful than any other country in defaulting on their debts, including the reparations demanded from them by the Allies. But, argues Ferguson, 'this victory was pyrrhic: democratic politicians at the expense of democracy and their own power won it. ${ }^{8}$

Moggridge avoids the issue of the accuracy of Keynes' numbers and does not give a view one way or the other as to whether he thinks Keynes exaggerated his figures. Rather he chooses to focus on what he sees as Keynes' vision in Economic Consequences against how things played out. For example, he argues that in 1919 Keynes probably underestimated the recuperative power of capitalist economies after major wars. German recovery after 1918 , as after 1945 , was substantial. By the mid-1920s at the latest, output levels exceeded pre-war levels - as did real wages. ${ }^{9}$ Germany's manufacturing exports did not return to pre-war levels. On the other hand the decline was not as severe as Britain's. ${ }^{10}$ According to Moggridge, it is also the case that Keynes' long-standing worry about the tendency for the terms of trade for primary products, especially foodstuffs, to automatically turn against manufacturers' terms of trade to the detriment of European standards of life, was misplaced, as well as 'theoretically incorrect.' However, Keynes was correct about the importance of frontiers, as the economic disintegration of the inter-war European economy was to demonstrate. ${ }^{11}$

\footnotetext{
${ }^{8}$ Ferguson, (1999, p. 397).

${ }^{9}$ Moggridge (1992, p. 345), from Phelps Brown and Browne, (1967, Appendix 3).

${ }^{10}$ Moggridge, (1992, p. 345), from Maizels, (1964, p. 189).

${ }^{11}$ Moggridge, (1992, p. 345), from Svennilson, (1954).
} 
Moggridge argues, the most important thing Keynes missed was the significance of French concerns about security from future German attack. Keynes acknowledged Clemenceau's 'vision' of a secure Europe but begged to differ over the wisdom of weakening the German economy over the longer term. In disagreeing, he ignored the political dimension of such worries and as a result his success in Britain in making the moral and economic case against the Treaty left France feeling more isolated and more prone to use the reparations issue as the vehicle for prolonging conflict. If he had allowed for French concerns he would have recognised that in place of the softening of the Treaty's terms on reparations, France required other guarantees from her allies. 


\subsection{Statistics and The Economic Consequences of the Peace}

Some economists believe Keynes objected to the general use of quantitative methods in economics, but this argument does not stand up to close scrutiny. ${ }^{12}$ In places he draws heavily on statistics as a means of description, clarification and verification for his arguments. For example, reference to Tables 7 to 22 above show in considerable detail how heavily Keynes' arguments around reparations and Germany's capacity to pay rested on statistics. As has already been argued, Keynes was conscious of the persuasive and rhetorical impact of his use of statistics. Rather than object to the use of quantitative methods in economics, Keynes objected to the particular misuse of methods developed to investigate phenomena that differed fundamentally from the economist's field of inquiry. Keynes, himself a trained mathematician and author of an important work on probability, was nevertheless hostile to the extensive use of mathematics and regression analysis in economics, which is today an important part of the discipline of econometrics. At the time of writing Economic Consequences the discipline of econometrics, insofar as it brings together a theoretical and statistical framework for the analysis of economic data, was in its infancy. However, by the 1930s econometrics had been accepted, as a branch of economics and Keynes himself was one of thirty economists from all over the world selected by the Council of the Econometric Society to constitute the first group of Fellows of the Society. In 1944 he was elected President of the Econometric Society, serving in the role for two years. ${ }^{13}$

Yet Phelps argues Keynes rejected the extensive use of econometrics largely because he viewed the future as being essentially different from the past and because he believed the extensive use of mathematics encouraged economists to turn from the

\footnotetext{
${ }^{12}$ For example, see Brady, (1988, p.1), where he cites a number of scholars who he argues misrepresent Keynes views on the use of mathematics.

${ }^{13}$ Patinkin, (1976, p. 1092).
} 
important question of choosing which among many economic models is appropriate for a particular situation, to the intellectually taxing, but practically unimportant, manipulation of a single economic model. ${ }^{14}$ While Keynes stated these views explicitly, it would be a mistake to say he did not accept the importance of quantification for economic analysis. On the contrary, as already stated, Keynes drew on "descriptive statistics" heavily in most of his written work. Reference to Section 5.1. above shows how extensive his use of statistics was. Keynes would most likely have agreed with Bartholomew who argues, 'a prime role of statistics in social science is to provide a quantitative framework within which [questions such as "the quality of life in Britain is worse than 20 years ago"] can be precisely framed and scientifically answered. ${ }^{15}$ For Keynes it was not so much a need to create new concepts as to understand precisely those numbers which already exist and thus 'render the theorising of the social scientist precise and testable. ${ }^{16}$ In Economic Consequences Keynes methods were those of an empiricist and inductivist, and in this regard he adopted the legacy left by the first acknowledged individuals, William Petty (1623-87) and John Gaunt (1620-74), to seriously draw on quantification methods in order to gain a better understanding of economics.

\footnotetext{
${ }^{14}$ Phelps, (1980, p. 483).

${ }^{15}$ Bartholomew, (1995, p. 9).

${ }^{16}$ Bartholomew, (1995, p. 9).
} 


\subsection{The Origins of Quantification in Economics}

Most economists credit Petty with being the first to take economic quantification seriously. Maddison argues macro-economic analysis began with Petty's aggregate accounts' of property and labour income, population, labour input, and capital stock for England and Wales in Verbum Sapienti (1665). In addition to his pioneering work of macro-economic measurement Petty also engaged in a wide range of activities intellectual, entrepreneur, physician, social engineer, inventor, and confidant of kings. He was 'an exemplar of a new kind of cosmopolitan western intellectual, one of the finest examples of the English enlightenment.' ${ }^{17}$ As with virtually all subsequent analysts in the field of macro-measurement and analysis, Petty's approach was inductive, trying to interpret the world by close study of the facts and systematic quantification. He adhered to the precepts of Francis Bacon (1561-1626) and is considered the founding father and ideas man of a group with several members. John Gaunt, the first demographer, developed procedures that foreshadowed modern historical demography and was a close friend of Petty. The third member was Gregory King (1648-1712) who systematised and extended Petty's macro-economic accounts and developed Gaunt's demographic analysis. A fourth member, Charles Davenant (1656-1714) was an analyst of fiscal policy and war finance options, problems of colonies and foreign trade, who interacted closely with King and used his estimates in assessing the costs and benefits of policy options. Maddison argues, 'the most striking thing about these political arithmeticians' is the modernity of their macro-economic approach and anticipation of concepts and methods, which now characterize national accounts' and historical demography. ${ }^{18}$

If, as it appears, Petty was the first 'economist' to take quantification seriously, an obvious question is, why were Petty and his contemporaries the first to gather data in

\footnotetext{
${ }^{17}$ Maddison, (2007, p. 249).

${ }^{18}$ Maddison, (2007, p. 249).
} 
ways not previously attempted? Cullen's view is these men were reformists looking for solutions to complex social problems. He argues Petty's vision was the 'first expression of a type to be found repeatedly in the history of social statistics, the reformer who saw the collection of facts as an indispensible preliminary to practical and effective reforms. ${ }^{19}$ The facts Petty and his contemporaries chose to collect, as with later statisticians, were designed to demonstrate the necessity and desirability solely of those reforms, which he desired, thus establishing a long tradition of the rhetorical use of numbers. Furthermore, Petty not only believed the role of political arithmetic as a science of society was dependent upon "number, weight, and measure" but he also subscribed to the view that for the science to be successfully studied it was necessary the raw data should be greatly improved. In numerous papers Petty argued for the creation of a central statistical office and often saw himself in the role of chief statistician.

But it was not until the nineteenth-century, with the establishment of the Statistical Department of the Board of Trade, founded in 1832, that real improvement in macro-economic measurement took place. Statistical offices collected data on trade, transport, fiscal and monetary matters, employment, wages, and prices. There was an increasing array of information on commodity output in agriculture, mining and manufacturing. Index number techniques were developed, which made it possible to measure temporal changes or interspatial variance of complex aggregates. However, as Maddison points out, while data collection and analysis techniques had improved since Petty's day, 'there was little improvement in [the quality or comparability of national income estimates for individual countries] over those of the seventeenth-century. ${ }^{20}$ Statistics that were gathered generally concentrated on the income dimension with no crosschecks on the expenditure and production side. They provided little help for serious analysis of economic growth and were generally spot estimates for a given point in time,

\footnotetext{
${ }^{19}$ Cullen, (1975, p. 5).

${ }^{20}$ Maddison, (2007, p. 287).
} 
with significant inter-country variance in coverage and methodology. Cullen argues, the problem did not lie with accepted theory that argued the fundamental importance of gathering statistical data, but rather the theory masked the true intention of the statisticians. Cullen argues, 'time and again, the statisticians embarked upon surveys, the major conclusions of which were anticipated or preconceived. ${ }^{21}$

Significant improvement on the work of the Statistical Movement in early Victorian Britain began later in the nineteenth- and into the twentieth-century, and then because of the work of two economists, Michael Mulhall (1836-1900) and Colin Clark (1905-89). Mulhall made a major contribution to international comparison of data by providing standardised estimates of 22 countries representing about $60 \%$ of world product in 1894 5. He measured value added items for each country and divided their economies into nine sectors, estimated gross output in each sector, and made an adjustment to deduct inputs so as to avoid double counting. Mulhall was considered by many to be the most innovative "economic statistician" since the time of Petty, and was Clark's hero. ${ }^{22}$ Like Petty, Clark began as a scientist and was self-taught in economics. He also had multiple ambitions as a scholar, politician, and public servant. In 1937 he produced the first integrated accounts for the United Kingdom, which measured the growth of income, expenditure, and production at current and constant market prices. He linked his estimates for 1913 with those of Gregory King for 1688 to provide historical perspective. He demonstrated the importance of national accounts as a tool of economic policy and his work was the precursor of the first official national accounts, created by Meade and Stone in 1941. Clark was also the first to present estimates of real income levels across countries adjusted for differences in the purchasing power of currencies, which were merged with inter-temporal measures of GNP in real terms of the type he had previously produced. This created a framework for comparative analysis of performance in space and time,

\footnotetext{
${ }^{21}$ Cullen, (1975, p. 146).

${ }^{22}$ Maddison, (2007, p. 287).
} 
'which was to revolutionise the possibilities for comparative economic history, and analysis of problems of growth and development. ${ }^{23}$

Clark also interacted closely with Keynes, although this was later in Keynes' career, following Clark's membership of the Economic Advisory Council, which he joined in February 1930 when Keynes was already a member. Clark became a Cambridge lecturer in statistics in the economics faculty (1931-7) and with Keynes (in 1940) pioneered macroeconomic measurement as a basic analytical tool for policy analysts and economic historians. Keynes' How to Pay for the War demonstrated the usefulness of statistical measurement as a tool for macroeconomic management and Clark's Conditions of Economic Progress demonstrated its value in interpreting economic history.

An important consideration of King's early empirical work had been the discovery of 'laws' in economics, similar to those in physics and other natural sciences. While the 'physical determinism' that followed the Newtonian revolution came to have far-reaching consequences for the method as well as the objectives of research in economics, the uncertain nature of economic relations only began to be fully appreciated with the birth of modern statistics in the late nineteenth century and as more statistical observations on economic variables started to become available.

The development of statistical theory gathered pace at this time. Also the earliest application of simple correlation analysis in economics was carried out by Yule (1895, 1896) on the relationship between pauperism and the method of providing relief and by Hooker (1901) on the relationship between the marriage-rate and the general level of prosperity in the United Kingdom, measured by a variety of economic indicators such as imports, exports and the movement in corn prices. Other steps towards what we now know as the discipline of econometrics took place around the turn of the twentieth century, although many acknowledge it was the work of Henry Moore $(1914,1917)$ that

\footnotetext{
${ }^{23}$ Maddison, (2007, p. 288).
} 
laid the important foundations of the discipline. Moore was the first to place statistical estimation of economic relations at the centre of quantitative analysis in economics. Eatwell and Newman argue, 'Moore [along with his disciples and followers] in effect laid the foundation of 'statistical economics,' the precursor to econometrics. ${ }^{24}$ Important early work in building on this foundation included a unification of theory and measurement in demand analysis; research in business cycles that provided the basis for later developments in time-series analysis and macro econometric model building and forecasting; the investment cycle discovery; the inventory cycle; and the long wave; all owe their subsequent work to early business cycle analysis.

Keynes would undoubtedly have been aware at the time of writing Economic Consequences of recent developments in the growing discipline of statistical economics but the complete absence from his book of any theoretical discussion or use of economic theory indicates Keynes stood firmly in the tradition of the early pioneers in the use of statistics for descriptive purposes and insofar as he sought reform through his economic arguments, his use of statistics followed the Victorian reformist methods of statistical usage. However, his use of statistics to help describe was also done so as to not confuse his readers with what might otherwise be an unintelligible inclusion of numbers. By so doing his use of statistics was more likely to be persuasive, in the same way in which his predecessors used numbers rhetorically.

\footnotetext{
${ }^{24}$ Geweke, Horowitz and Pesaran, (2008).
} 


\subsection{Keynes' Use of Statistics in Economic Consequences}

Although Keynes did not embrace the use of econometrics as it emerged as a discipline in the 1930s and 1940s the importance he placed on the use of statistics continued for the remainder of his life, clearly evidenced by How to Pay for the War. ${ }^{25}$ However, unlike How to Pay for the War his use of statistics in some earlier works appears unsystematic and designed entirely for descriptive and rhetorical purposes. While presentation is cogent, there is no clear, structured or systematic way in which Keynes deals with his statistical arguments. However, as with How to Pay for the War, Keynes always used numbers to establish authority, support and verify arguments. Despite the unsystematic presentation, Keynes' use of statistics remained largely unaltered throughout his career. Moggridge points out; Keynes' views on the use of statistics were first formed with his 1907 and 1908 fellowship dissertation submissions, and subsequently published as $A$ Treatise on Probability in 1921. Many of his arguments reappear 'in his discussions of statistical arguments between 1910 and $1940 .^{\prime 26}$ At the heart of his use of statistics were two parts he argued made up the theory of statistics: the descriptive part concerned with presenting, describing and summarising series of events or instances; and the analytical part that is inductive or inferential and is concerned with extending the description of certain characteristics of observed events to those not observed.

A good example of Keynes' use of this theory of statistics is his discussion of "Germany's capacity to pay" (refer to Tables 12 to 17 above). This is also a good example of his seemingly unsystematic presentation. Keynes maintained the most Germany could afford by way of reparations was somewhere between $£ 1000$ million and $£ 2,000$ million (versus the Committee on Indemnity's estimate of $£ 24,000$ million and Treasury's $£ 2,000$ million to $f 3,000$ million) but to understand fully how Keynes arrived at these figures

\footnotetext{
${ }^{25}$ Keynes, (1940).

${ }^{26}$ Moggridge, (1992, p. 160).
} 
takes analysis of 133 pages of integrated prose and statistical arguments, with no easy way of arriving at Keynes' summary figures. ${ }^{27}$ Furthermore, when Keynes does provide some analysis, for example to justify his maximum figure of $£ 2,000$ million, we find this is just one set of inductive calculations. ${ }^{28}$ In other words, Keynes used a variety of different methods and calculations, drawn from a wide range of statistics, to support his argument that $f 2,000$ million was the maximum of Germany's capacity to pay.

There are four probable explanations for this unsystematic presentation. First the figures appear to be drawn together in a hurried and pragmatic manner as part of official Treasury memoranda and almost unchanged when presented in Economic Consequences. The use of memoranda typically involves a style of writing that is "informal." The way in which prose and statistics in memoranda, attributed to Keynes, are grouped by numbers, similar to the use of bullet points, reflects this informal approach. Second Keynes incorporates many of the statistics from these memoranda into Economic Consequences, in places almost verbatim. Third, he does not seek to restructure the informal approach typical of official memoranda, although in Economic Consequences there is a "merging" of these informal "notes" into a prose style. A final explanation can be found in the actual maturity of the discipline of economics at this time.

An initial analysis of Germany's capacity to pay had been undertaken by The Treasury during hostilities, with a number of estimates provided in a Treasury memorandum dated January 1916, the authors being W. J. Ashley ${ }^{29}$ and J. M. Keynes.

${ }^{27}$ Keynes, (1919, pp. 60-193).

${ }^{28}$ Keynes, (1919, p. 186).

${ }^{29}$ Ashley (1860-1927) is best known for his work as an economic historian. He differed with Marshall and his followers who sought to sideline economic history in favour of establishing economics as a science. He wrote a book in 1888 Introduction to Economic History and Theory where he outlined his differences with the Marshallians. He argued that deductive, abstract reasoning could not provide the basis for meaningful or effective economic theory or practice, and that statements of economic principle were true only in relation to given historical conditions. With the outbreak of the First World War he was drawn into government ...Footnote continued on next page... 
When the Imperial War Cabinet set up the Committee on Indemnity on 26 November 1918 Keynes was called on to be representative of the Treasury where he used this earlier memorandum to warn the committee: '[While] our investigation is not yet complete, but so far, it looks very probably that the amount of reparation [calculated by the committee] is larger than the amount that Germany can pay. ${ }^{30}$ The report of the committee, which was never published, came to the conclusion that Germany should pay the whole cost of the war, estimated at $£ 24,000$ million, a figure Lloyd George branded as a wild and fantastic chimera, at the same time as the Treasury's investigations were showing that Germany was capable of paying something between $£ 2,000$ million and $£ 3,000$ million. Keynes thought that without economic growth to stimulate her exports Germany could pay $£ 1,000$ million of moveable property at once and $£ 1,000$ million additional tribute amortised over thirty years. Detailed workings were provided to the committee in a memorandum headed: 'Notes on an Indemnity' and dated 31 October 1918. According to Johnson these 'appear to have been Keynes' work alone.' ${ }^{31}$ In a letter to his mother on 3 November Keynes remarked, 'an exciting incident of the week was writing a memorandum on indemnities at top speed for an airman to fly to Versailles with. ${ }^{32}$

The final memorandum, the structure of which is followed closely in Economic Consequences, was finalised during November 1918 and most probably presented to the committee at the meeting Keynes attended on 2 December $1918 .{ }^{33}$ The verbatim lifting of paragraphs into Economic Consequences, from this memorandum, was done, according to

service, largely as an expert adviser on, for example, the departmental committee of food prices in 1916, and the Sumner committee on the cost of living in 1918, where his statistical knowledge was at a premium. Source: Green, (ONDB, 2004, 30472).

${ }^{30}$ Keynes, (CW, XVI, p. 337).

${ }^{31}$ Keynes, (CW, XVI, p. 337).

${ }^{32}$ Keynes, (CW, XVI, p. 338).

${ }^{33}$ Keynes, (CW, XVI, p. 336). 
Johnson, because Keynes must have felt the final version to be enough of his own work without having to formally acknowledge these figures as being Treasury statistics. It is fortuitous the original hand-written manuscript of Economic Consequences has survived and can be found in the archives at King's College, Cambridge. Whereas most of the manuscript's prose is hand written, many of the statistics have been 'cut and pasted' from original Treasury documents into the handwritten manuscript, an example of which is given in Figure 5 below.

In this example everything that is not highlighted in \{parenthesis\} is the original wording from the Treasury memorandum. That is to say, \{carried on\}, \{during the war\} and so on, have been added to Economic Consequences but do not appear in the memorandum. The words in bold italics, such as continuously conducted, in the Reichsbank and so on, are in the original memorandum but have been deleted from the book. A close examination of these amendments shows that Keynes, in places, relies substantially on Treasury statistics in support of his arguments, with changes to 'cut and pasted' memoranda being relatively minor.

\section{\{1.\} Immediately Transferable Wealth}

(a) Gold. After the deduction of the gold to be returned to Russia, the official holding of gold as shown in the Reichsbank's return of the $30^{\text {th }}$ November 1918 amounted to $f 115,417,900$. This was a very much larger amount than had appeared in the Reichsbank's return prior to the war, and was the result of the vigorous campaign which has been continuously conducted \{carried on\} in Germany \{during the war\} for the surrender to the Reichsbank not only of gold coin but of gold ornaments of every kind. Private hoards doubtless still exist, but, in view of the great efforts already made, it is unlikely that either the German Government or the Allies will be able to unearth them. It is not known whether the Reichsbank or the government possess a secret hoard but, as every effort has been made throughout the war to counteract the effect of a largely increased note issue by showing as much gold as possible in the Reichsbank's return, it is extremely unlikely that any substantial amount is held by the government 
outside this return. The return \{can\} should therefore be taken as probably representing the maximum amount which the German Government \{are\} have been able to extract from their people. In addition to gold there $\{$ was $\}$ is \{in the Reichsbank\} a sum of about $f$ $1,000,000$ in silver in the Reichsbank. There \{must be\} is, however, a further substantial amount in circulation, \{for $\}$ the holdings of the Reichsbank having been \{were as high as $f 9,100,000$ on the $31^{\text {st }}$ December 1917, and having stood at about $£ 6,000,000$ up to the latter part of October 1918, when the internal run began on currency of every kind. We may, therefore, take a total of (say) $£ 125,000,000$ for gold and silver together at the date of the Armistice\}. ${ }^{34}$

\section{Figure 4: Example of how Keynes 'cut and pasted' from Memoranda into}

\section{Economic Consequences}

A fourth explanation for the unsystematic way Keynes presents his statistics is the level of maturity of the discipline of economics in 1919. Although Marshall had chartered the way for the professionalisation of economics, in the early part of the twentieth century economists had yet to achieve the professional status they were to gain by midcentury. For example, when Lloyd George wanted economic advice as Chancellor before the First World War he turned to a financial journalist, George Paish, editor of the Statist. ${ }^{35}$ Until the 1930 s economics was something that government officials who had studied philosophy or mathematics at Oxford or Cambridge were expected to be able to 'get up,' if required, and many candidates for the Civil Service examination did so. Keynes himself studied mathematics at Cambridge, and his initial training in economics amounted to no more than directed reading over a summer vacation. Yet, in 1908 , within three years of graduation, he was considered to be qualified not only as a lecturer in economics at

\footnotetext{
${ }^{34}$ The handwritten manuscript reference is: JMK/EC/8 p. 276. The equivalent section in Keynes, (1920, pp. 156-7).

${ }^{35}$ Peden, (2000, p. 23).
} 
Cambridge but also as joint editor of the Economic Journal. During the war he was recruited into the Treasury, where he became head of a new division dealing with overseas finance, but his duties differed only in subject matter from those of other officials.

Another example that highlights the relatively unsophisticated nature of economics at this time is the estimates of national income made by the Treasury between 1914 and 1916. Peden points out these estimates did not represent a serious attempt at analysis of the kind made during the Second World War, which required macroeconomic concepts developed by Keynes during the 1930s. Peden argues, 'the use made of national income estimates in the First World War was bound to be unsophisticated. ${ }^{\prime 36}$ Another example of the relatively unsophisticated nature of economics was when Chancellor of the Exchequer, Reginald McKenna used figures in 1916 simply to support his claim that the National Debt created during the war would not be an intolerable burden, since the Debt to be created by the end of 1916/17 would be approximately the same as a year's national income. ${ }^{37}$ Influences such as shifting price levels and inflation were not taken into account in these estimates and subsequent authors have argued, these unsophisticated calculations help explain why taxation levels were insufficient to assist with the financial burden created by war.

In summary, Keynes used statistics in line with the way he understood the theory of statistics to be applied. In the first place this meant describing a series of events. In one example Keynes presents, describes and summarises Germany's holdings of gold and silver at the date of the Armistice. He reasons inductively to argue that of the $£ 125,000,000$ of gold and silver he estimates is available to the Reichsbank, just $£ 60,000,000$ can realistically be made available for reparations (see Table 12). The second

\footnotetext{
${ }^{36}$ Peden, (2000, p. 93).

${ }^{37}$ Peden, (2000, p. 93).
} 
thing about his use of statistics in Economic Consequences is, while the figures used follow the cogency of his prose, the statistics themselves are presented in an unsystematic and informal manner. There are four explanations for this. First the informal way in which arguments are made, best evidenced by his use of numbered points, similar to bullet points, in earlier memoranda. Second, the statistics pulled together for the memoranda that ultimately led to the final memorandum and presented to the Committee on Indemnity, were constructed against a background of pressure and expediency. In short, there is a clear element of pragmatism over statistical elegance in Keynes' presentation. The third explanation for the unsystematic presentation is the way he brings figures from Treasury memoranda into Economic Consequences. There is little effort at amendment or tidying up from figures previously gathered under pressure and in a hurry, as is evidenced by the large amount of 'cutting and pasting' from Treasury documents into his manuscript. Finally, the state of economics as a discipline and the more sophisticated attention being paid to the use of statistics in the 1930s and 1940s did not exist in 1919 and while it is acknowledged Keynes played a major role in the mathematical developments of the 1930s and 1940s his unsystematic use of statistics in the war years and immediate post-war period reflected the nature of the discipline at this time. 


\subsection{The Challenge to Keynes' Statistics}

Many modern day economists believe Keynes exaggerated his statistics. This judgment can be traced to Mantoux's critical analysis of Economic Consequences. However, Mantoux's book was published some twenty six years following the publication of Keynes' book and invariably suffers, as has been argued, from 'the benefit of hindsight.' There had been nothing equivalent to challenge Keynes' numbers and calculations when he published in 1919, which leave us with some important questions. Why did it take so many years after the publication of such a plethora of statistics to mount a challenge to Keynes' statistical claims? Why, if Keynes' figures were so exaggerated so as to border on falsity, were they so widely accepted without challenge at the time of publication? And, to what degree does it really matter? If Keynes was able to persuade his readers with selectively chosen statistics, but careful to draw on reputable sources, is this not a commonly chosen path for those wanting to persuade an audience? This line of argumentation does, however, raise the question of how far we can trust the veracity of numbers used rhetorically, in the same way we might challenge the veracity of prose arguments constructed for political purposes. On the other hand it does not follow that the use of persuasive rhetoric is by its very nature lacking in truthfulness or credibility. Keynes understood the "rules of rhetoric" from the time of Cicero were about the persuasive presentation of an argument with the veracity of content uncompromised.

\subsubsection{Contemporary Reaction and the Reparations Debate}

It has been shown reaction to Keynes' book came from many different quarters and grew to a considerable quantity. However, most contemporary reaction was directed at the book's prose with questioning of the veracity of Keynes' statistics relatively muted. Economic Consequences had stirred up considerable controversy around Keynes' depiction of the political leaders, especially Wilson, who attended the Versailles Conference. In addition to this Keynes' views on reparations and Germany's "capacity to pay" generated considerable debate. But, as has been noted, most people seemed to accept without challenge the many statistics Keynes presented. Halperin comments, 'strangely enough, 
while the politics of Keynes' book was the object of much controversy, its economics were almost never seriously challenged. ${ }^{38}$ Moggridge in his discussion of contemporary reaction lumps any criticism of Keynes' statistics as being among 'other criticisms of Economic Consequences [that] fastened on details. ${ }^{39}$ Where, however, Keynes took seriously any criticism of his figures and calculations, he was careful to correct his critics' and did not accept any figures as being better than his own.

Keynes' exchange with John Foster Dulles is a good example of this 'fastening onto details' and Keynes' rigorous defence of his statistics. The fact Keynes considered Dulles' letter the 'first serious and responsible' criticism of his book is helpful in shedding light on the nature of the contemporary debate around the numbers Keynes used. Putting to one side Dulles' discussion of the inclusion of pensions and separation allowances and what he proposes by way of accounting methods, Dulles's chief complaint was Keynes' calculation of reparation liability. ${ }^{40}$ Keynes had argued that the reparation liability should immediately be fixed at $£ 2,000$ million but Dulles maintained Keynes took no account of the marked appreciation of values during wartime. Dulles maintained that an additional $£ 2-3,000$ million needed to be added to Keynes figure of $£ 2,000$ million. He also challenged Keynes' figure of $£ 1,500$ million to be paid over thirty years. Dulles argued this amounted to a present capital sum of approximately $£ 750$ million (that is, only half of Keynes figure of $£ 1,500$ million).

\footnotetext{
${ }^{38}$ Halperin, (1946, p. 932).

${ }^{39}$ Moggridge, (1992, p. 339).

${ }^{40}$ The debate around the inclusion or exclusion of pensions and separation allowances had more to do with the moral efficacy of their consideration. Keynes was aggressively opposed to any inclusion of such items, which meant there was little point in bothering too much about debating the actual numbers when he did not think they should be considered in the first case. On the subject of accounting treatment for reparations Dulles argues in his letter that even if this was not the intended figure that should be paid by way of reparations, standard commercial practice was to record what creditors owed to their debtors. Refer to Keynes, (CW, XVII, p. 24).
} 
Keynes responded to Dulles' criticisms:

(1) [That he had not taken account of the marked rise in prices from 1913 to 1919.] 'This criticism is not well founded. My initial allowance for increased prices, the wide margin I added for contingencies, and the fact that my estimates were in terms of gold and not paper francs, result, so far, for example, as the restoration of houses is concerned, in my upper limit leaving room for an appreciation in the cost of house building, in terms of francs, to nine or ten times the pre-war level. (2) My estimate of what Germany could pay - namely $£ 2,000$ million at the most. Mr. Dulles does not comment on this estimate. The progress of events since I made it has not led me to modify it upwards. (3) My estimate of what it would be wise on our part to ask from Germany - namely, $£ 2,000$ million, but with the two important abatements of a rather large allowance for ceded property and the payment of the balance in 30 annual instalments without interest. Mr. Dulles thinks my suggested allowance for ceded property too large, on the ground that it would be mainly for war material having little value to the Allies. I intended this figure to cover a great deal besides war material, as, for example, merchant ships, submarine cables, and rolling stock, as well as State property and financial liabilities attributed to ceded territory. ... (4) Lastly, there was the German counter proposal of an alleged sum of $£ 5,000$ million, which to judge from his speech in the House of Commons on February 12 achieved at least as much of its object to deceive Mr. Balfour. But of course the real value of Count Rantzau's offer was nothing of the kind, as I have explained in detail in pp. 204-209 of my book, and, indeed, as the Allies themselves have pointed out in the official reply which they addressed to him. ..... Mr. Dulles ... does not dispute my estimate of the real money value of the offer as being somewhere about $f 1,500$ million. But he forgets that even this figure is not comparable with those cited above, since the German offer was conditional on the abandonment of most of the rest of the treaty, including all the 
territorial clauses and those relating to the mercantile marine and to German property abroad $^{.41}$

Two aspects of this exchange are striking. First, Keynes goes into detail as to how he arrived at his figures (refer point 1) and helps explain why there has been considerable debate around the statistics he used. In short, statistics can never be taken at face value. If we do not have access to source numbers and an understanding of the methodology used to derive the statistics, analysis becomes difficult and doubt cast on the veracity of the numbers. If Keynes had a methodology for deriving his statistics it is not obvious from the archival material, which has survived. However in this letter to Dulles he talks of using a contingency factor, allowing for price changes and his use of the valuation of gold rather than the exchange rate for francs. This suggests Keynes had some way of calculating his numbers. However, if he did there seems little consistency to the way he applied his methodology, which means we are left with a high degree of speculation when trying to "get behind" Keynes' numbers. What Keynes did reasonably well was to provide the reader with references to many of his sources. But this just adds to what we do know, which is that Keynes was interested in statistics as a means of description and authoritative support for his arguments.

The second aspect of importance about this exchange is it is representative of the challenge to Keynes' statistics. Anything to do with the subject of reparations often led to debate and disagreement. Moggridge argues critics fastened onto three aspects of this debate: the nature of the Armistice contract and hence the morality of the inclusion of the claim for pensions and separation allowances; the size of the claims for reparation; and Germany's capacity to pay. On the first, the debate was one of morality and principle rather than actual figures. If, as Keynes maintained, it was immoral to even consider including pensions and separation allowances then a debate about figures has no meaning. On the second, it is important to note Keynes' 1919 estimate of Germany's

\footnotetext{
${ }^{41}$ Keynes, (CW, XVII, pp. 26-28).
} 
liability for reparations was remarkably close to that of the Reparations Commission. In 1921 the Commission set Germany's liability at $£$ 6,600 million. Keynes' estimate was $£ 6,400-8,800$ million. But, this misses the real point of the debate. The point is, as Moggridge argues, the numbers prove nothing, they establish only orders of magnitude. As such they indicate that in terms of 'normal' national income ${ }^{42}$ and late 1920 s average exports, 'the Allies' demands for reparations from Germany were large relative to German demands on France in 1871 or to other historically large financial transfers. ${ }^{43}$

Keynes, with Ashley, had foreseen this difficulty as early as 1916 and argued in their Treasury memorandum that historical examples are the fairest way to determine reparations. They used the most recent example they were familiar with, which was the French reparations following their war with Germany from 1870-71. As a proportion of national income the annual figure for France (1871-5) was 7.5-12 per cent. ${ }^{44}$ France's indemnity in 1871, of 5 billion francs, represented less than a quarter of a year's national income. This compared to the Allies' post-1918 demands of Germany, which represented over one and a half times the highest estimates of Germany's national income in the second half of the 1920s. However, as Moggridge points out, and has been argued already, the numbers mean very little; they only establish an order of magnitude and as such indicate that in terms of 'normal' national income and late 1920s average exports, the Allies' demands for reparations from Germany were large relative to German demands on France in 1871 or to other historically large financial transfers. Furthermore, the German payments were to continue for a much longer period than those of 1871 . This ruled out the possibility of substantial recycling as had occurred in 1871 because when

\footnotetext{
${ }^{42}$ Refer above to the way in which the use of national income statistics by McKenna led to difficulties in meeting war time debt burdens due to the unsophisticated way in which income was calculated. Peden, (2000, p. 93).

${ }^{43}$ Moggridge, (1992, p. 343).

${ }^{44}$ Moggridge, (1992, p. 342) from Machlup, (1976, Ch. XV) and Trachtenberg, (1980, pp. 67-8).
} 
there is a stream of payments for several decades ahead, "borrowing to service or anticipate a substantial portion of these payments is hardly feasible. ${ }^{45}$ Some borrowing might transfer some payments from earlier to later years when incomes and trade would be greater, but for payments the size of those demanded in 1919 a large proportion would have to come from current international earnings.

While there was considerable debate at the time around reparation claims, the issue which dominated was Germany's capacity to pay reparations and the economic consequences of such payments. One complication in the debate was that the reparation sum was set in nominal terms in foreign currency. A worldwide rise in prices would reduce the real resource costs of any transfer of reparations, a fall would increase it. During the nineteenth century the trend of prices had been flat, but fluctuations around the trend were significant and lengthy. Moggridge argues, Keynes having grown up in such a stable era, would have been more worried about the risk of a significant fall in prices as this would have the effect of paying large nominal sums over a long period more worrying than in the present day when we live, comparatively speaking, in an inflationary world.

When it came to determining Germany's capacity to pay, most economists were interested in Germany's ability to expand her exports and/or decrease her imports of goods and services to effect the transfer. The relevant issues in this debate are the time allowed for the changes in question, the magnitude of the changes, and the structure of the relevant markets. On the question of time, Keynes conceded that if the Allies nursed the Germany economy back to health over a period of five to ten years they could obtain larger streams of payments than otherwise. There was little disagreement over this view. But there was room for disagreement as to the prospect of such time being allowed and the extent of the 'nursing' involved. Keynes, looking at the Treaty and the financial policies of the Allies, was pessimistic on both counts.

\footnotetext{
${ }^{45}$ Moggridge, (1992, p. 343).
} 
On the question of magnitude the question had to be asked, could Germany transform her international accounts so as to produce an export surplus of the relevant size even if the Allies allowed? Was it possible by appropriate policy measures to reduce domestic consumption and raise Germany's net international receipts? Moggridge argues, to a modern economist the answer would be 'yes in theory.' A mixture of tax, monetary and exchange-rate policies would reduce domestic consumption and raise the output of goods moving into international trade relative to those which did not. But in 1919 this was not a theoretical question. Keynes was arguing there was nothing to give on the consumption side and, especially after the other Allied depredations of the Treaty, resources were not available and were not likely to be available in the foreseeable future. His opponents took a different view, often arguing that Keynes underestimated the recuperative power of the German economy and at the same time the Treaty would in any case be modified to ease the burdens. Moggridge argues, 'certainly, looking at the magnitudes involved, the figures above, though high, are not impossible for a more normal period. Whether the results would meet the needs or desires of the Allies was another matter. ${ }^{46}$ However, for any serious attempt by Germany to pay reparations, which there never was, as laid down in the Treaty, would have required a substantial net increase in her exports of coal and manufactured goods. Such an expansion would have inevitably been at the expense of other producers.

But, the question as to whether or not Germany had the capacity to pay reparations on the scale demanded by the Treaty was never put to the test. In the late 1920s, German reparation payments averaged just over 1.5 billion marks - less than 2 per cent of national income or just over 13 per cent of her exports. ${ }^{47}$ The proportions rose with the 1929 slump, but it was only in those years that German's export surplus was actually needed to cover her reparations bill, for prior to 1929 German capital imports had

\footnotetext{
${ }^{46}$ Moggridge, (1992, p. 344).

${ }^{47}$ Moggridge, (1992, p. 344) from Machlup, (1964, p. 384, pp. 392-3).
} 
more than offset her reparations payments. The system collapsed shortly after. The general consensus is, Germany could have paid more if there had been a willingness to pay in Germany, a willingness on the part of the Allies to receive and a willingness to tackle associated problems, 'but whether she could have managed the figures of 1919 remains an open question. ${ }^{48}$

In summary, the most significant aspect of the contemporary reaction to Keynes' use of statistics in Economic Consequences is that reaction was relatively muted. However, this reaction demonstrates how numbers used authoritatively can be used rhetorically.

\subsection{2. Étienne Mantoux: The Carthaginian Peace or the Economic Consequences of Mr. Keynes}

As has been shown, the first serious and analytical challenge to Keynes' statistics came from Étienne Mantoux with his book The Carthaginian Peace or The Economic Consequences of Mr. Keynes. However, Mantoux's book was published some twenty-six years after Keynes' book first appeared. Nevertheless, Mantoux's analysis is systematic and thorough and concludes that the economic defects of the Versailles Treaty were 'exaggerated and illusory.' Mantoux argues that in general Keynes overestimated the impact of change of the volume of international trade and in particular, the activity of the German economy, while underestimating the ability of the post-war German economy to produce a national income large enough to raise the revenue necessary to pay reparations. An examination of one example of Mantoux's challenge, the so-called ceding of Upper Silesia to Poland, is illustrative of how Mantoux mounted his campaign against Keynes.

Keynes had argued Upper Silesia had been part of Germany for 1000 years, produced 23 per cent of the total German output of hard coal and was ' essential to the

\footnotetext{
${ }^{48}$ Moggridge, (1992, p. 345).
} 
economic life of Germany,' and without which her industries could not prosper. ${ }^{49}$ However, Mantoux argued this was a disingenuous argument because first, the area had not been ceded as part of the Treaty but was to be subject to a plebiscite some time into the future that would leave it to the people of the region to decide whether they preferred to be part of Germany or Poland. But more significantly Germany was to be given access to Polish coal, free of all export duties for a period of fifteen years. In any event the region was partitioned between Poland and Germany following the promised plebiscite in 1921 and by 1925 Germany had notified Poland that they would accept no more duty-free consignments of coal from Poland. A tariff war ensued, 'and in 1926, German economists were writing that Germany could henceforward do without Polish coal, and had better protect her industry against its invasion. It must be conceded that the Treaty makers had shown a poor understanding of 'economic realities'., 50

Mantoux's challenge went to the heart of many more of Keynes' arguments. For example, Mantoux argued, the German economy during the inter-war period disproved Keynes' argument Germany would not be capable of generating an adequate export surplus. Furthermore, Keynes had predicted Europe would be threatened with 'a long, silent process of semi-starvation and of a gradual steady lowering of the standards of life and comfort, yet 'ten years after the Treaty, European production was well above its prewar level, and European standards of living had never been higher. ${ }^{51}$ Keynes had predicted a decline in the iron output of Europe when in fact output increased almost continuously. Mantoux also argued, 'in 1929 Europe produced 10 per cent more iron than in the record year, 1913. ${ }^{52}$ Keynes had also predicted a decline in iron and steel output of

\footnotetext{
${ }^{49}$ Keynes, (1919, p. 79).

${ }^{50}$ Mantoux, (1946, p. 83).

${ }^{51}$ Mantoux, (1946, p. 83).

52 Mantoux, (1946, p. 83).
} 
Germany but by 1927 it was 30 and 38 per cent higher, respectively, than in 1913, within the same territorial limits. He forecast a decline of efficiency in the German coal mining industry but by 1929 the efficiency of labour was 30 per cent higher than in 1913. Keynes also predicted Germany could not export coal in the near future, yet in the first year following the Treaty, German net coal exports were 15 million tons and in 1926, 35 million tons. He estimated Germany's national savings for future years at less than 2 billion marks. In 1925 the figure was estimated at 6.4 billion and in 1927 at 7.6 billion. Keynes also predicted Germany could not afford to pay more than 2 billion marks a year in reparations for the next 30 years, yet between 1933 and 1939 Germany spent seven times as much a year on re-armament alone.

Mantoux used these figures to estimate the effect on Germany's net capital formation before 1929 and this, combined with her arms expenditure under Hitler, led him to the conclusion that Germany could have easily covered the heaviest possible Versailles reparation annuities, which exceeded by four times what Keynes admitted to be her capacity to pay. Mantoux also dismissed as insignificant Keynes' contention that it is one thing to raise "unprecedented" reparation sums and another to transfer them, due, as has been shown from Moggridge's arguments, to an inevitable breakdown of the mechanism of foreign exchange. He points to the extractions of large contributions from the countries occupied by Germany in World War II and the operation of the Lease-Lend system to 'explode the time-honoured myths about the inherent evils of an adverse balance of payments!' Mantoux also argued there was in reality no transfer problem and Keynes' figures were faulty when it came to calculating Germany's capacity to pay. He also attacked Keynes' contention that 'the perils lay not in frontiers or sovereignties, but in food, coal and transport.' Mantoux instead argued that it is the reverse which had proven to be true, stating,

the size and shape of nations, and ... the problem of frontiers "remain," in the words of Lord Curzon, "the razor's edge on which hang suspended the modern issues of war or peace, of life or death of 
nations." Whatever increases the economic significance of the State will inevitably increase the economic significance of frontiers. ${ }^{53}$

There were a number of other challenges, including the claim Germany's so-called destitution was by and large an exaggeration and was 'created by juggling figures in an arbitrary fashion; ${ }^{54}$ the German inflation was of its own volition; Germany drew far more capital from abroad, on the bulk of which it subsequently defaulted, than Germany had to pay; reparations received were imports free of charge and as such did not "beggar" the receiver; Germany's ability to pay had been fully proven by the fact of its ability to spend on armaments at a higher rate than Germany was ever asked to pay on reparations; and the allegedly insoluble problem of transferring payments from one country to another was solved by the Nazis who annually "transferred" out of occupied countries ten times the reparation annuity.

Whether we accept these arguments is not as important as the legacy Mantoux left. It enables a challenge to Keynes' claims as well as giving the debate a fresh and revised set of views, along with some analytical means for assessing the veracity of Keynes' figures. However, Mantoux's work suffers from a significant defect. Hindsight, as is commonly stated, is "a wonderful thing" and much of Mantoux's analysis is taken up dealing with Keynes' figures as if Keynes had fixed them as predictors of the future, when in many cases he used numbers based on what was known at the time and according to assumptions about the future. In a number of cases events turned out far differently than could have been foreseen. In the process we are left with statistics, which only have meaning at a particular point in time and within a set historical context. A more convincing analysis would have been to uncover the methods and reasoning Keynes used in compiling his statistics. This would have helped better expose how Keynes used figures for purposes of persuasion and give a better idea of whether Keynes deliberately exaggerated his

\footnotetext{
${ }^{53}$ Mantoux, (1946, p. 83).

${ }^{54}$ Payli, (1947, p. 391).
} 
statistics. The other difficulty of Mantoux's challenge is, Keynes was never in a position to respond to Mantoux's criticisms, having died shortly before Mantoux's book was published. Tragically Mantoux had also died the previous year, killed during the final days of World War Two.

Most subsequent reviews of Mantoux's book were, however, sympathetic to his challenge and most economists since overwhelmingly side with Mantoux in broadly criticising Keynes for exaggerating. ${ }^{55}$ However, as with much of the contemporary criticism of Keynes' figures, it is difficult to assess with any certainty their validity, primarily because his critics provide little or no analytical evidence for their views. Rather they are happy to accept "Mantoux is right; Keynes was wrong."

Hawtrey's Economica review stands out as something of an exception to this overwhelming sympathy for Mantoux's arguments and in so doing helps explain why Keynes may have been as concerned as he said he was with the situation in 1919. It has already been argued that other scholars drew attention to Germany's difficulties and Hawtrey is another who agreed Germany had been placed under an impossible burden in 1919, although figures were not fixed until 1921 when the first cash payment of reparations started the collapse of the mark. Hawtrey acknowledges the argument that the German government may have been able to avert the result but he points out, with the progress, or rather lack of progress, made in restoring German finances, and the monetary stability that had been maintained for a full year up to May 1921, 'I do not think that accusation can be sustained. But if it were, the Allies had no means of imposing

\footnotetext{
${ }^{55}$ A number of reviews of Mantoux's book appeared shortly after its publication. See, Rappard, (October 1946), American Political Science Review; Heilperin, (December 1946), American Economic Review; Hillmann, (January 1947), International Affairs; Jones, (January 1947), American Journal of International Law; Angus, (February 1947), Canadian Journal of Economics and Political Science; Viner, (March 1947), Journal of Modern History; Warren, (July 1947), Annals of the American Academy of Political and Social Sciences; Palyi, (July 1947), Review of Politics; Hawtrey, (August 1948), Economica; Albrecht-Carrie, (June 1953), Political Science Quarterly; Parker, (June 1954), Journal of Political Economy.
} 
financial rectitude on Germany, short of assuming an overriding authority, which would have amounted to the supersession of the sovereign Republic by an Allied Military Government. ${ }^{56}$ Nobody wanted this outcome. Hawtrey also argues, with the inflation of 1921-3 such payments as Germany made were at the cost of depleting the working capital of German industry and trade. It was for the indispensable purpose of reconstituting this working capital that Germany borrowed on so great a scale from London and New York and other centres in the years 1924-9.

Hawtrey next addresses the transfer problem and asks, what if transfer had been found possible? That, argues Hawtrey, would have brought Keynes' argument into play that Germany had in effect 'engaged herself to hand over to the Allies the whole of her surplus production in perpetuity. ${ }^{, 57}$ The charge of some $£ 40$ million a year for thirty years, according to Hawtrey, would have deprived German economic life of the essential resources of development, or indeed of maintenance, since capital outlay on technological improvements 'is an indispensable condition of competitive power. ${ }^{58}$ This was Hawtrey's rebuff to Mantoux's argument, that 'it would not have been economically impossible to exact payments in excess of what was necessary to maintain Germany's national capital intact. $^{59}$ For Hawtrey this supported Keynes' view that such an imposition on Germany would have meant nothing less than long drawn-out ruin, which had always been Clemenceau's aim. This would, of course, have freed France from the German threat but, as Keynes had argued, it would have invited their destruction as well.

Hawtrey also addresses Mantoux's main argument, that the Allies were in a position to make Germany hand over something more than the whole of her surplus, but,

\footnotetext{
${ }^{56}$ Hawtrey, (1948, p. 236).

${ }^{57}$ Keynes, (1919, p. 154).

${ }^{58}$ Hawtrey, (1948, p. 236).

${ }^{59}$ Mantoux, (1946, p. 112).
} 
owing to the influence of Keynes' book, they failed to do so. Germany did retain enough of her surplus to achieve a rapid and almost complete recovery, and thereafter used her renewed economic power to re-arm on a scale almost sufficient for her to subjugate the world. But when Mantoux argued 'that the surplus which Germany yielded to Hitler for rearmament and war can be taken as a measure of what could have been made available for reparations,' Mantoux, argues Hawtrey, was making some rather considerable assumptions. Was it, Hawtrey asks, conceivable in the Europe of 1919 that anything like the savage system of coercion, repression and espionage to which Hitler resorted could have been imposed on any human society? And surely, he goes on, even in a world habituated to the outrage of totalitarianism, it would have been impossible to extract any comparable surplus in opposition to the patriotic sentiments of the community instead of with their support. He argues, 'the German enslavement of populations of invaded countries during the Second World War was a desperate throw, and met with very limited success.' Finally Hawtrey points out, even if arguments had favoured emasculating Germany as Keynes believed the Treaty terms would do, 'in the relatively humane world of 1919 it was a matter of course that resources would flow to a country reduced to urgent need, from more prosperous centres. The idea of destroying German economic power by imposing excessive reparation liability was really moonshine from the beginning.' 60

${ }^{60}$ Hawtrey, (1948, pp. 237- 238). 


\subsection{Conclusion - Keynes and Statistics}

Many present day economists argue Keynes exaggerated Germany's inability to meet reparation terms in the Treaty. Typically they point to the way Keynes underestimated Germany's economic restorative capability, ultimately one of the reasons for World War Two. Some go as far as to lay the blame for Germany's rapid ability to rearm on Keynes' publication of Economic Consequences. However, this view enjoys the benefit of hindsight and does not sufficiently take account of the context within which Keynes' statistics were drawn.

I have argued that many of Keynes' figures were taken, often verbatim, directly from Treasury memoranda. While in many cases these figures were undoubtedly the work of Keynes himself, as a Treasury official, they are statistics, prior to any form of publication that would have been known to those he worked with. It seems unlikely the entire Treasury would have been complicit in turning a blind eye to deliberately exaggerated figures. However, this does not mean Keynes used statistics other than as a means to persuade his readers. Keynes understood the importance and "rules" of rhetoric. There are numerous examples in Economic Consequences where he effectively marshals numbers and calculations in ways to support his arguments. Keynes believed the terms as laid out in the Treaty would not only emasculate Germany economically, but his real concern was that the Treaty, if imposed, would, in effect, throw the whole of Europe into an economic dark age.

There is little doubt he was successful in persuading many of his generation. Apart from the obvious publishing success of his book, the clearest evidence is the widespread acceptance of his figures. Some researchers suggest this is because they were deliberately presented in a confusing manner, whereas Keynes' prose could easily be challenged because he wrote with a clear and elaborate style. However, this overlooks that Keynes himself saw his book as a serious work of economics and his extensive use of Treasury numbers tends to support this argument. It also overlooks that Keynes' numbers drew little criticism at the time and were accepted by many of his otherwise critical and knowledgeable audience. To suggest otherwise is to cast doubt on the intellectual ability of Keynes' own contemporaries' analytical abilities and their understanding of Keynes' statistical arguments.

Page 247 


\section{Chapter 6. Economic Consequences of the Peace:}

\section{Prose Style}

This chapter highlights the wide range of literary sources, metaphors, analogies and allusions Keynes used to describe Europe as it looked into an abyss of economic desolation. He placed much of the blame on politicians who came to Versailles and who, through weak and incompetent leadership, were ushering in a new world order of economic backwardness and negotiating a Peace, which was a continuation of war by peaceful means.

Keynes' use of metaphors, allusions and analogies were used to capture the imagination of his readers, with sources he knew would be familiar to them. For example, his descriptions of weak and inept leadership are compared to President Wilson as a 'blind Don Quixote' and Lloyd George as the 'Anti-Christ' (Anti-Christian) whose individual scheming and manipulation renders Wilson a hapless and ineffective leader. This means disappointment in Wilson, which Keynes accentuates by comparing him to Napoleon, not in the victorious sense but in the sense of failure of promise and impotence. Tolstoy, Hardy and Shaw all wrote of Napoleon in this way. Keynes is just as critical of Clemenceau and refers to the ways he put the interests of France before all other concerns, similar to the misplaced love of Pericles for Athens.

Keynes saw little opportunity for rectifying this weakness of leadership and none measured up to the ideal of Plato's 'philosopher-king.' The deliberate manipulation of the intent of the Fourteen Points highlighted just how weak the leaders were so that right became wrong and wrong became right, illustrated by the witches scene from Shakespeare's Macbeth ('fair is foul and foul is fair.')

This picture of incompetent and impotent leadership created in Keynes a feeling of despair as he drew from writers such as Wordsworth and Shelley to prophesy an apocalyptic future for Europe. This apocalyptic theme runs through the entire book and 
there is inevitability about the march towards economic misfortune Keynes believed would engulf Europe. This inevitable march echo's Hardy's "Immanent Will" that would result in yet another European civil revolution and economic dark age, as unavoidable as the sinking of the Titanic had been.

However, despite the dark and persistent tone of Keynes' central arguments he finishes his book on a note of hope the situation can be remedied. He offers a number of solutions for replacing the Treaty terms with a set of economic measures designed to head off the possibility of civil war and economic devastation. He finishes his book with a quotation from Shelley's Prometheus Unbound, which is telling. While Shelley's poem is a response to the revolutions and changes affecting society in the nineteenth century, this work is Shelley's answer to the mistakes of the French Revolution and its cycle of replacing one tyrant with another. In this poem Shelley attempts to show how a different form of revolution would break the cycle, in the same way Keynes believed a different approach and set of measures for restoring economic prosperity to Europe would address the consequences of a Carthaginian Peace. 


\subsection{Prose and Style in Economic Consequences of the Peace}

Keynes' understanding of the rules of rhetoric and his explicit attempts at persuasion meant a heightened awareness of how best to construct his prose. For a book committed to serious economics, his use of metaphors is extensive in Economic Consequences. It has been argued, a writer's use of metaphors activates what Fyre calls the "imaginative cosmos" in the reader's mind and enables them to better grasp the message. The successful use of metaphors can also have a powerful effect on the way a reader reacts to language. For example, when Keynes referred to the Peace Treaty as a "Carthaginian Peace" it shocked many readers educated in the history of the ancient and classical worlds. The Roman destruction of Carthage had been total and for Keynes to liken the economic consequences of the Treaty to total economic destruction was a devastating critique from an eminent economist.

While Keynes understood the power of metaphors he also understood they needed to be used correctly and with relevance to have the desired effect. In an early draft of Economic Consequences Keynes reveals something of what he means. Writing about Lloyd George he commented:

But lest we lose ourselves in metaphor, we must return to the commonplace of the Conference. I will enumerate briefly the chief factors influencing the part played by the British Prime Minister. If the reader will consider these, still holding the metaphors freshly in his mind, he will understand the outcome in such measure as it is in my power to convey to him. ${ }^{1}$

This section examines the ways Keynes used metaphors to communicate and how this contributes to defining Keynes' unique writing style.

\footnotetext{
${ }^{1}$ Draft Manuscript of Economic Consequences held in the King's College archives; JMK/EC/9 (box 14), p. 55.
} 


\subsubsection{Prophetic and Apocalyptic Literature}

Keynes develops a number of themes in Economic Consequences using the genre of prophecy and apocalypse to emphasise his arguments. He prophesies there will be economic consequences from Versailles which will negatively affect all nations of the world. His apocalyptic warning is that all nations will be plunged once again into a destructive European civil war should the terms of the Treaty be imposed. Keynes provides a number of examples of how words were manipulated during the drafting of the Treaty so the original intentions of the Fourteen Points were undermined and a heavier economic burden imposed on Germany than was agreed in the earlier Armistice negotiations. Keynes wrote,

So far, however, all this is only a matter of words, of virtuosity in draftsmanship, which does no one any harm, and which probably seemed much more important at the time than it ever will again between now and Judgment Day. ${ }^{2}$

Keynes' prophecy is clear. While the draftsmen's work seems just a matter of words, virtuous even, there is an evil intent woven into those words which will ultimately result in a judgment day when those responsible for imposing the Carthaginian Peace will be held to account.

Keynes' use of biblical references such as this, in addition to his use of references from literary figures known to write in a prophetic and apocalyptic style, such as Percy Bysshe Shelley and William Butler Yeats, is a good indicator that Keynes intended Economic Consequences should be included in the tradition of prophetic and apocalyptic literature. Prophetic literature, also called oracular and orphic literature, positions the

\footnotetext{
${ }^{2}$ Keynes, (1919, p. 141).
}

The term Judgment Day comes from Christian eschatology, the Last Judgment Day or Day of the Lord is the judgment by God of every human who ever lived and will take place after the resurrection of the dead and the Second Coming. Refer: Revelation 20: 12-15. 
writer between humanity and another world (supernatural or non-human). The idea is found in many ancient cultures. ${ }^{3}$ Within the European and American literary traditions, prophetic speech that links the individual creative artist with forces larger than the individual has been part of several movements. For example, the Pre-Raphaelites objected to the humanism that was a feature of the Renaissance and looked for an earlier, more holistic, art that had a tradition of using prophetic language. The English Romantics, such as Shelley, found in nature a prophetic source of inspiration and a model for human societies. American Transcendentalists found inspiration in an oversoul ${ }^{4}$ and Surrealists sought to move past the logic of the waking mind and to draw from more universal material in the unconscious. Imaginism based art on a deep connection with an object outside the self, thus allowing some of its practitioners to develop an art with prophetic content. While Modernism generally discouraged writers from employing a prophetic voice to connect humanity with the more-than-human, some authors, especially those whose work reflects concern for the natural world and/or social justice, such as Keynes, embraced the role. ${ }^{5}$

\footnotetext{
${ }^{3}$ For example, the Celt's practice was for the bard to hold the King accountable to his sacred vows to land and people. In Greece, the oracles at Delphi and other sacred sites gave pronouncements in a highly stylised form of prophetic speech. Among indigenous North Americans, spiritual and/or political leaders such as The Great Peacemaker used oracular rhetoric to artistic effect in delivering their messages. In the biblical tradition prophets' spoke God's message without fear or favour. The message varied according to the circumstances of the time. For example, seventh- and eighth-century prophets' faced Kingdoms that were often complacent in the face of increasingly powerful empires based in Mesopotamia but whose economic and political structures oppressed the weak and poor. After the fall of Jerusalem in 586BCE by contrast, the prophets' addressed discouraged people who often lacked hope that God could or would save them from pagan empires and their many gods. Source: Ashe, (2003).

${ }^{4}$ The origin of oversoul lies in Eastern religious traditions. One definition is the absolute reality and basis conceived as a spiritual being in which the ideal nature imperfectly manifested in human beings is perfectly realised.' Source: Merriam-Webster Dictionary. The term entered popular currency in the West following Ralph Waldo Emerson's publication of The Oversoul in 1841.

${ }^{5}$ In its broadest definition Modernism describes a set of cultural tendencies and a variety of associated cultural movements arising from wide-scale and far reaching changes to Western Society from around 1890 to 1930. The term covers the activities of those who felt that the traditional forms of art, architecture, ...Footnote continued on next page...
}

Page 252 
Apocalyptic literature also has a rich tradition but is not to be compared to prophetic literature as it was a new genre of prophetical writing that developed in postexilic Jewish culture and was popular among millennialist early Christians. "Apocalypse" is from the Greek word for "revelation" which means 'an unveiling or unfolding of things not previously known and which could not be known apart from the unveiling. ${ }^{6}$ The apocalyptic literature of Judaism and Christianity embraces a considerable period, from the centuries following the exile down to the close of the Middle Ages. The origins of the apocalyptic genre arise from moments of unfulfilled prophecy. Whereas the message of the prophets was primarily a preaching of repentance and righteousness if the nation was to escape judgment, the message of the apocalyptic writers was of patience and trust for that deliverance and reward that would eventually arrive. The writing itself is often fearful, violent, with a vision that reveals truths about past, present and future times in highly symbolic and poetical terms. Towards the end of Economic Consequences Keynes provides an example when describing the United States impulse to give up on Europe and the 'folly and impracticability of the European statesmen.' Keynes uses a reference from William Wordsworth's The Excursion Book Third ${ }^{7}$ to poor scorn upon them all:

Rot, then, in your own malice, and we will go our way -

Remote from Europe; from her blasted hopes;

Her fields of carnage, and polluted air. ${ }^{8}$

Wordsworth's words are from the tale of a wanderer's sensation, expressing emotions of despondency, affliction, dejection and solitariness. Roused by the French Revolution the

\footnotetext{
literature, religion, social organisation and daily life were becoming outdated in the new economic, social and political conditions of an emerging fully industrialised world. Source: Bradbury and McFarlane (1991).

${ }^{6}$ Goswiller, (1987, p. 3).

${ }^{7}$ Wordsworth, (2007).

${ }^{8}$ Keynes, (1919, p. 268).
} 
wanderer leaves to journey to America but disappointment and disgust pursue him. On his return he experiences languor and depression of mind, from want of faith in the great truths of Religion, and want of confidence in the virtue of mankind. These were similar to the "apocalyptic" feelings that gnawed at Keynes as he wrote Economic Consequences.

While Keynes paints an apocalyptic picture of the failings of the statesmen, whose job it was to provide leadership in the restoration of the fortunes of a battered Europe, Keynes also turns his apocalyptic words of "chastening" on the 'great capitalist class' of Europe calling for reform and arguing this is the class that should be taking responsibility for restoring European fortunes. Instead of ushering in reform Keynes rather sees the capitalist class as contributing to future ruin and muses that 'perhaps it is historically true that no order of society ever perishes save by its own hand.' In this passage Keynes deals with the past, assuming it to be historically true, and the present:

We are thus faced in Europe with the spectacle of an extraordinary weakness on the part of the great capitalist class, which has emerged from the industrial triumphs of the nineteenth century, and seemed a very few years ago our all-powerful master. The terror and personal timidity of the individuals of this class is now so great, their confidence in their place in society and in their necessity to the social organism so diminished, that they are the easy victims of intimidation. This was not so in England twenty-five years ago, any more than it is now in the United States. Then the capitalists believed in themselves, in their value to society, in the propriety of their continued existence in the full enjoyment of their riches and the unlimited exercise of their power. Now they tremble before every insult; - call them pro-Germans, international financiers, or profiteers, and they will give you any ransom you choose to ask not to speak to them so harshly. They allow themselves to be ruined and altogether undone by their own instruments, governments of their own making, and a press of which they are proprietors. ${ }^{9}$

\footnotetext{
${ }^{9}$ Keynes, (1919, p. 222).
} 
In his concluding discussion of the failure of the capitalist class Keynes hints prophetically at the coming apocalypse ${ }^{10}$, which was to be World War Two:

In the complexer world of Western Europe the Immanent Will may achieve its ends more subtly and bring in the revolution no less inevitably through a Klotz or a George ${ }^{11}$ than by intellectualisms, too ruthless and self-conscious for us, the bloodthirsty philosophers of Russia. $^{12}$

The term Immanent Will comes from the work of Hardy, who is examined below. Hardy did not subscribe to the great man view of history but rather fate in the form of the Immanent Will dictates how events unfold.

The prophetic and apocalyptic themes running through Economic Consequences are brought to a dramatic conclusion with Keynes' reference to Prometheus Unbound at the end of the book. ${ }^{13}$ His reference is used to call for the replacement of another potentially destructive form of revolution, to the kind just waged, with a constructive revolution of economic possibility by restoring Europe to prosperity. Prometheus Unbound was a four-part play written by Shelley and Keynes makes full use of the apocalyptic genre to reinforce his point the "end times" will descend upon the nations of Europe should they not heed the message of his book:

In this autumn of 1919 , in which I write, we are at the dead season of our fortunes. The reaction from the exertions, the fears, and the sufferings of the past five years is at its height. Our power of feeling

\footnotetext{
${ }^{10}$ In apocalyptic tradition things get worse before they get better, hence another revolution (that was World War Two).

${ }^{11}$ Reference is to Lloyd George and Louis Lucien Klotz who was the French Minister of Finance during the war. Keynes had no time for Klotz and was heavily critical of him.

12 Keynes, (1919, pp. 222-223). Keynes's reference to the bloodthirsty philosophers of Russia is clearly referring to the intellectuals such as Lenin and Trotsky who ushered the Bolsheviks into power.

${ }^{13}$ Grabo, (1968).
} 
or caring beyond the immediate questions of our own material wellbeing is temporarily eclipsed. The greatest events outside our own direct experience and the most dreadful anticipations cannot move us.

In each human heart terror survives

The ruin it has gorged: the loftiest fear

All that they would disdain to think were true:

Hypocrisy and custom make their minds

The fanes of many a worship, now outworn.

They dare not devise good for man's estate, And yet they know not that they do not dare.

The good want power but to weep barren tears.

The powerful goodness want: worse need for them.

The wise want love; and those who love want wisdom;

And all best things are thus confused to ill.

Many are strong and rich, and would be just,

But live among their suffering fellow-men

As if none felt: they know not what they do.

We have been moved already beyond endurance, and need rest. Never in the lifetime of men now living has the universal element in the soul of man burnt so dimly. ${ }^{14}$

${ }^{14}$ Keynes, (1919, pp. 278-279). 
The paragraph introducing the extract from Prometheus Unbound uses three forms of rhetoric: Keynes' use of the metaphor "dead season" paints a bleak picture; the passage itself could be described as "high rhetoric," such are the descriptions of despair; there is no transition from Keynes' discursive statement about the despair he sees around him and the non-discursive Prometheus Unbound. It also serves Keynes' purpose that he finishes this section of poetry with the words of Jesus Christ on the cross, "they know not what they do." Shelley had left out the first few words used by Christ, "Forgive them, for," that again suits Keynes' purpose. He has no intention of forgiving the politicians whom he blames for the poor state Europe finds itself in but rather damns them for not knowing what they are doing.

The original Prometheus Unbound is a play by the Greek poet Aeschylus concerned with the torments of the Greek mythological figure Prometheus and his suffering at the hands of Zeus. This inspired Shelley's play of the same name, first published in 1820 . It was not intended to be produced on the stage but was in the tradition of Romantic Poetry. Shelley wrote for the imagination, intending his play's stage to reside in the imaginations of his readers. Shelley seeks to create in his play a perfect revolutionary in an ideal, abstract sense. In the apocalyptic tradition it could be loosely based upon the Jesus of both the Bible, Christian orthodox tradition, as well as Milton's character of the Son in Paradise Lost. The portrayal of Jesus from all three literary canons as the Son who sacrifices himself to save mankind highlights for Shelley how the perfect revolutionary must go through a period of sacrifice before he or she can save mankind. Prometheus resembles Jesus in that both uncompromisingly speak truth to power, resulting in a period of persecution, after which the truth overcomes tyranny in the same way Prometheus overcomes his tyrant, Jupiter.

There is widespread agreement that Shelley wrote Prometheus Unbound as a response to the revolutions and economic changes affecting his society, and the old views of good and evil needed to change in order to accommodate the current civilization. The Prometheus Unbound quotation used by Keynes from Shelley's play is also repeated in William Butler Yeats' poem The Second Coming, first published in The Dial (November Page 257 
1920). ${ }^{15}$ Yeats, by his own admission, was in "religious awe" of Shelley's play and in The Second Coming draws on religious symbolism to illustrate his anguish over the apparent decline of Europe's ruling class, similar to Keynes' anguish over the timidity of the European capitalist class. Yeats also uses this religious symbolism to support his occult belief that Western civilization, if not the whole world, was nearing the terminal point of a 2000-year historical cycle. As with Shelley and Keynes, Yeats was concerned with the revolutions that had gone before, including the Irish, German and Russian revolutions, in addition to the French Revolution. Of these, the Russian Revolution concerned Yeats and Keynes the most. Like Keynes, Yeats believed the world was on the threshold of an apocalyptic moment although his vision of destruction rendered by "the beast" differs from Keynes' vision of reconstruction through revolution. Yeats was ambivalent in how he felt about the beast but he found it more satisfying, rather than terrifying, and approved of its brutality and a period of complete destruction if a new civilization was to arise "from the ashes." Keynes, on the other hand, took no satisfaction from the thought that further destruction should precede restoration.

In summary, we have seen how Keynes used statistics to support his point that Economic Consequences was a serious economic text. When turning to an examination of his use of metaphor to paint a prophetic picture of apocalypse, we find that rather than Economic Consequences being a piece of political polemic, as many of his critics maintained, Keynes rather used metaphors of prophecy and apocalypse to reinforce the seriousness of his economic arguments. His references to prophecy and apocalypse are used first to highlight how the drafting of the Treaty terms were manipulated and would put a heavier economic burden on Germany. Second, the failure of statesmen at the Conference would have economically destructive consequences for Europe far into the future. Third, Keynes called on the capitalist class of Europe to rise to the challenge of restoring economic prosperity so Europe would not 'perish by its own hand.' Finally,

${ }^{15}$ Albright, (1997). 
Keynes concluded his book with a quote from Shelley's Prometheus Unbound as an appeal to the Allied leaders to learn from the French Revolution and subsequent European civil conflicts so mistakes from these conflicts would not be repeated.

\subsubsection{Themes on the Failure of Leadership}

Keynes' use of prophetic and apocalyptic metaphors often refers to leadership as a key to halting Europe's march towards economic doom. In Economic Consequences Keynes has a great deal to say on the subject of leadership and in particular the failures demonstrated at the Conference. He used a number of analogies from the life and times of Napoleon to highlight these failures. Before World War One Napoleon's militarism had caused the last "civil war" experienced by Europe anywhere near the magnitude of 1914 to 1918.

However Keynes does not use references to Napoleon to explain the extent of military destruction wrought by Napoleon compared to that of the military leaders of World War One, but rather, he wants to draw the reader's attention to how the impotence displayed by Napoleon's enemies was similar to that of the Allied leaders in 1919.

Keynes argues, at the turn of the nineteenth century Napoleon posed an increasing threat to Europe in the same way the terms of the Treaty posed a threat to the safety and stability of all European nations, should the Allies proceed with enforcing them. He described 'the proceedings of Paris,' as a paradoxical event that

had this air of extraordinary importance and unimportance at the same time. The decisions seemed charged with consequences to the future of human society; yet the air whispered ${ }^{16}$ that the word was not flesh, ${ }^{17}$ that it was futile, insignificant, of no effect, dissociated from events.

\footnotetext{
${ }^{16}$ Giving the effect of an impalpable sense of doom or menace.

${ }^{17}$ From John 1:14 "The Word became flesh and made his dwelling among us." This was the Gospel of Good News, the long-prophesied Messiah coming down to earth was documented as part of the written canon of Jewish scripture and had arrived in the fleshly form of Jesus. However, here Keynes inverts the meaning.
} 
Paris had the effect of overturning any good news related to cessation of hostilities, such as the Fourteen Points, which had been essentially ignored or corrupted. Any saviour figure, such as Wilson who had come to the Conference with the hopes of the nations of the world vested in his person, had been diminished to the point where Keynes felt there was no hope.

Keynes then elaborates his analogy of Napoleon by quoting from both Tolstoy's and Hardy's fictionalized accounts of the Napoleonic threat. He explained that

one felt most strongly the impression, described by Tolstoy in War and Peace or by Hardy in The Dynasts, of events marching on to their fated conclusion uninfluenced and unaffected by the cerebrations of Statesmen in Council:

Spirit of the Years

Observe that all wide sight and self-command

Deserts these throngs now driven to demonry

By the Immanent Unrecking. Nought remains

But vindictiveness here amid the strong,

And there amid the weak an impotent rage.

Spirit of the Pities

Why prompts the Will so senseless-shaped a doing?

Spirit of the Years

I have told thee that It works unwittingly,

As one possessed not judging. ${ }^{18}$

\footnotetext{
${ }^{18}$ Keynes, (1919, pp. 4-5).
} 
Keynes described: the vindictiveness of the Allies (vindictiveness here amid the strong); the anger associated with the impotence felt by Germany and her defeated allies (And there amid the weak an impotent rage); a feeling of frustration from observers such as Keynes at such senseless actions (Why prompts the Will so senseless-shaped a doing?); and Keynes' view that the leaders at Versailles had put together a Treaty more out of emotional revenge than considered judgment of the consequences (I have told thee that it works unwittingly, As one possessed not judging).

The sentiments in Hardy's poem are closely mirrored in the prose from Tolstoy's War and Peace. ${ }^{19}$ For Keynes this summarised the position Wilson, Clemenceau and Lloyd George found themselves in at the Conference. Tolstoy did not subscribe to the "great man" view of history since he believed events shaped themselves and great men take advantage of them. While Napoleon was such a man, who took advantage of the French Revolution, Keynes saw the "Statesmen in Council" at Paris as taking advantage of the events of World War One to exact a "Carthaginian Peace" on Germany. Furthermore, Keynes argues that impotence defined the leadership at Versailles and was similar to the impotence felt by the five aristocratic families from Tolstoy's novel who were caught up in Napoleon's siege of Moscow. There are no great men in War and Peace or at the Versailles Conference. There is only 'vindictiveness here amid the strong, and there amid the weak an impotent rage. ${ }^{20}$

Keynes' next reference with Napoleon is again a comparison with the leaders at Versailles, this time Napoleon and President Wilson as men of great promise, that is, each as 'a man of destiny from the West.' ${ }^{21}$ This analogy is from Shaw's play The Man of

\footnotetext{
${ }^{19}$ Moser, (1992).

${ }^{20}$ Keynes, (1919, p. 4).

${ }^{21}$ Keynes, (1919, p. 35).
} 
Destiny, written in $1898 .{ }^{22}$ In the play, Napoleon Bonaparte, at 27 , is a young man on the rise, with great promise and expectations of things to come. Shaw's play is set on $12^{\text {th }}$ May, 1796, in the north of Italy, at Tavazzano, on the road from Lodi to Milan. Two days previously, at Lodi, the Austrians had tried to prevent the French from crossing the bridge. But, the French, commanded by Napoleon, had rushed the 'fireswept' bridge and overcome the Austrians. This young commander was 'an original observer,' whose mastery of cannonading was a 'technical specialty' based on a 'highly evolved faculty for physical geography and for the calculation of time and distance.' Furthermore, this man of great promise, 'had prodigious powers of work, and a clear, realistic knowledge of human nature in public affairs, having seen it exhaustively tested in that department during the French Revolution. ${ }^{23} \mathrm{He}$ is, in short, a man with the expectations of an entire nation resting on his actions and success. Similarly, Wilson had taken the moral high ground and demonstrated strong leadership with his acceptance of the Armistice and the framing of the Fourteen Points, thus ending hostilities. When Wilson arrived at Versailles it was with great promise and expectations the US and her Allies could rely on his ability to negotiate a successful peace.

\section{According to Keynes,}

when President Wilson left Washington he enjoyed a prestige and a moral influence throughout the world unequalled in history ... with what curiosity, anxiety, and hope we sought a glimpse of the features and bearing of the man of destiny who, coming from the West, was to bring healing to the wounds of the ancient parent of his civilization. ${ }^{24}$

But, in the same way the promise and hope Napoleon could heal the wounds of the French Revolution ended in disillusion, so too the promise and hope President Wilson

\footnotetext{
${ }^{22}$ Holroyd, (1991).

${ }^{23}$ Holroyd, (1991).

${ }^{24}$ Keynes, (1919, p. 34-35).
} 
could heal the wounds of Europe's bloody civil war also ended in disillusion, so much so, 'that some of those who had trusted most hardly dared speak of it. ... What had happened to the President? What weakness or what misfortune had led to so extraordinary, so unlooked-for a betrayal. ${ }^{25}$

While Keynes' comparison of Wilson to Napoleon highlights disappointed expectations, his later reference to Napoleon is for a different reason. In a section devoted specifically to the problems of a weakened Russia as well as Germany, Keynes suggested a set of remedies for heading off the apocalyptic doom he thought would result from a weakened Germany. Keynes refers to Napoleon and a possible 'new Napoleonic domination, rising, as a phoenix, from the ashes of cosmopolitan militarism,' should the Allies seek to economically weaken both Germany and Russia. ${ }^{26}$ At the time of writing Economic Consequences the Allies had blockaded Russia in the hope this would bring the Bolshevik threat to an end. For many of Keynes' readers, both a weakened Germany and a weakened Russia were necessary ways of ensuring the world did not plunge back into war and destruction. However, Keynes argued that

[Spartacism] in Germany might well be the prelude to Revolution everywhere: it would renew the forces of Bolshevism in Russia, and precipitate the dreaded union of Germany and Russia; it would certainly put an end to any expectations which have been built on the financial and economic clauses of the Treaty of Peace. Therefore Paris [as in the allies at the Versailles Conference] does not love Spartacus. ${ }^{27}$

Keynes has two reasons for the allusion to Spartacus. First, was the fresh memory of the Spartacus Revolt in Berlin in January 1919. The revolt had taken its name from the

\footnotetext{
${ }^{25}$ Keynes, (1919, p. 35).

${ }^{26}$ Keynes, (1919, p. 272).

${ }^{27}$ Keynes, (1919, p. 271).
} 
Spartacus League, a revolutionary socialist group active in Germany from autumn 1914 to the end of 1918. It was officially founded in 1916 by Karl Liebknecht, Rosa Luxemburg, Clara Zetkin, and Franz Mehring. The name derived from their illegally distributed pamphlets Spartakusbriefen (Spartacus Letters). The League developed as an offshoot of the Social Democratic Party, among elements who violently opposed Germany's role in World War One and who called for socialist revolution. The group was transformed into the Communist Party of Germany at a party congress held from December 30, 1918 to January 1, 1919. Following demonstrations encouraged by the group Luxemburg and Liebknecht were arrested in Berlin on January 15 and murdered by members of the Conservative Free Corps (Freikorps), who had seized control of the city's police presidium. $^{28}$

The second reason for the allusion to Spartacus is the equation of the Allies' policy of economic emasculation of Germany with the Roman slave Spartacus. Keynes by doing this suggests the opposite but equally unpalatable idea of an economically strong Germany that, for many people, would inevitably mean a new military power 'establishing itself in the East, with its spiritual home in Brandenburg. ${ }^{29}$ Historically Brandenburg was an independent state, which grew to become the core of independent Prussia and later the German state of Prussia and was the site of the kingdom's capitals, Berlin and Potsdam. For those who feared the possibility of a militarily strong Germany reestablishing itself within the geographical area of historic Brandenburg and giving rise to a new Napoleonic domination, this would be like the rising of the mythical phoenix bird. Keynes' allusion to the phoenix is prescient because of the legend it has a 1000 -year lifecycle, the same period of time Hitler attributed to the Third Reich, based as it was on the 1000-year existence of the combined Roman Republic and Empire, he believed he was bringing into being with a new world order and domination. The fears associated with the

\footnotetext{
${ }^{28}$ McHendry, (1992).

${ }^{29}$ Keynes, (1919, p. 271).
} 
scenario of a newly independent and militarily threatening Germany gave rise to the feeling among the Allies at Versailles that while 'Paris does not love Spartacus,' nor does 'Paris dare not love Brandenburg.' ${ }^{30}$ While Keynes expresses sympathy with the opposing viewpoints he argues there is only one remedy for the dilemma faced by the Allies and that is to recognise an economically strong Germany is in the best interests of all Europe just as an economically strong Russia would be. Furthermore, 'the blockade of Russia [for example] is a foolish and short-sighted proceeding; we are blockading not so much Russia as ourselves. ${ }^{31}$ By this use of personification, that is, depicting countries as characters, Keynes is able to portray the situation as dramatic and

the more successful we are in snapping economic relations between Germany and Russia, the more we shall depress the level of our own domestic problems. This is to put the issue on its lowest grounds. There are other arguments, which the most obtuse cannot ignore, against a policy of spreading and encouraging further the economic ruin of great countries. ${ }^{32}$

In short, because of impotent leadership, the Allies will bring economic ruin not just to Germany but also upon themselves and usher in a 'new Napoleonic domination' of all Europe.

In summary, Keynes' references and allusions to Napoleon and Spartacus enables him to develop three important themes. First there is the impotence of the Allied leaders and their failure to find effective economic solutions to the problems created by World War One. The second theme is of disappointed leadership expectations. In the same way Napoleon came to the European stage with great promise so too did President Wilson arrive at the Versailles Conference with great promise. However, both leaders proceeded

\footnotetext{
${ }^{30}$ Keynes, (1919, p. 272).

${ }^{31}$ Keynes, (1919, p. 274)

${ }^{32}$ Keynes, (1919, p. 277).
} 
to greatly disappoint their followers and supporters. Finally, Keynes uses the person of Napoleon to highlight the dilemma of re-building the economies of both Germany and Russia as it may lead to another Napoleonic domination of Europe. However, the only effective remedy for heading off such a threat was to do the very thing the leaders at the Conference feared most, to rebuild the shattered economies of both Germany and Russia, a remedy that nonetheless was in the best interests of all European countries. The success of this strategy and the way to ensure another Napoleonic era of domination did not take place was dependent on strong, effective leadership from the Allies. Instead the failure of leadership at Versailles had economic consequences that would put Europe back on a path of instability and eventual revolution.

\subsubsection{Other Themes: Allusions to the Classical World}

In addition to using metaphors and allusions focusing on prophecy, apocalypse and themes of leadership failure, Keynes also alluded to characters from the classical world to support his thesis that the consequences of the Allied leaders' decisions would be economic rather than political. In one example, Keynes refers to Pericles of ancient Greece to support his argument that Clemenceau's love of France was misplaced. When Keynes states, 'he [Clemenceau] felt about France what Pericles felt of Athens - unique value in her, nothing else mattered,' he does not say it as a compliment to Pericles and his love for Athens, which is not disputed, even by Pericles' critics, but rather makes the point that this love was misplaced. ${ }^{33}$ Pericles' critics regarded him as responsible for the gradual degeneration of the Athenian democracy, and for the destruction from the Peloponnesian War as well as being a prolific spender who effectively bankrupted the Athenian treasury, building expensive edifices and artworks. ${ }^{34}$ Clemenceau, argues Keynes, had 'no place for

\footnotetext{
${ }^{33}$ Keynes, (1919, p.29).

${ }^{34}$ Morkot, (1996).
} 
"sentimentality" in international relations. ${ }^{35}$ Nations are real things, of which you love one and feel for the rest indifference or hatred. The glory of the nation you love 'is a desirable end, - but generally to be obtained at your neighbour's expense'. ${ }^{36}$ Such misplaced love leads to destruction and undermines the very self-interest that motivated men such as Pericles and Clemenceau. Rather than being good for France, Clemenceau's politics are really 'the theory of politics of Bismarck ${ }^{37} \ldots$ an ingenious formula for rearranging the balance of power in one's own interest. ${ }^{38}$

Another significant theme Keynes developed in referring to the classical world was the "Carthaginian Peace" to be imposed on Germany by the Allies. This peace, Keynes argued, would mean total destruction for Germany and in turn the whole of Europe. Keynes was responsible for popularising the term Carthaginian Peace, ${ }^{39}$ which refers to the outcome of a series of wars between Rome and the Phoenician city of Carthage, known as the Punic Wars. ${ }^{40}$ At the end of the third Punic War the Romans laid siege to Carthage. When they took the city they killed most of the inhabitants, sold the rest into slavery, and destroyed the entire city. Some accounts say that the Romans then sowed the ground with salt, although this is considered a legend. Tacitus said, "they make a wasteland and call it peace." While this reference to Carthage was a reference to a peace that brought total destruction to the enemy, Keynes himself extended the term to argue

${ }^{35}$ Keynes, (1919, p. 29).

${ }^{36}$ Keynes, (1919, pp. 29-30).

${ }^{37}$ The theory of the politics of Bismarck comes from the time of Bismarck (1815-1898) and his Lückentheorie (gap theory). This maintained that in cases of conflict between crown and parliament the will of the former must prevail. During 1862-66 this enabled the king to expend tax monies on the military without approval of parliament.

${ }^{38}$ Keynes, (1919, pp. 29-30).

${ }^{39}$ A search of The Times online database back to the first issue of 1785 finds no reference to this term before December 1919 when The Times carried a review of Economic Consequences.

${ }^{40}$ There was a series of three Punic Wars fought from 264 to 146 BC. Source: Goldsworthy, (2001). 
that a Carthaginian Peace would inevitably swallow up the Allies as well as their enemies. The policy of France, Keynes argued, was to set the clock back to the time of the 1870 war between Germany and France in which France was humiliated by Germany. The revenge France now looked to exact upon Germany would be by loss of territory and destruction of her economic system built on the

vast fabric [of] iron, coal, and transport. [But] you cannot restore Central Europe to 1870 without setting up such strains in the European structure and letting loose such human and spiritual forces as, pushing beyond frontiers and races, will overwhelm not only you and your "guarantees," but your institutions, and the existing order of your Society. ${ }^{41}$

When writing in 1919 Keynes, despite his apocalyptic vision of an economically ruined Europe, held out hope, albeit a fading hope, that it was not too late to avoid the worst of the destruction. He argued this could be achieved with firm leadership from the United States. He uses the analogy of the "philosopher-king," which he believed would have been enough to blunt the excesses of French revenge. ${ }^{42}$ The philosopher-kings were the hypothetical rulers, or Guardians, of Plato's Utopian Kallipolis, his ideal city-state that, if it was ever to come into being, 'philosophers [must] become kings ... or those now called kings [must] ... genuinely and adequately philosophise. ${ }^{43}$ The vision of an ideal city-state evoked by Keynes' philosopher-king had parallels with the thinking of contemporaries such as H. G. Wells who had in 1918 been recruited by Lord Northcliff's Ministry of Propaganda. His task was to work on a statement of war aims chief among which was the setting up of the League of Nations. Wells had viewed the war as the inevitable outcome of rivalries between modern nation-states. Popular nationalism and imperialism reflected

\footnotetext{
${ }^{41}$ Keynes, (1919, pp. 32-33).

${ }^{42}$ Reeve, (c1988).

${ }^{43}$ The Republic, 5.473c.
} 
the prejudices and misunderstanding sown by the teaching of national history in each country. Wells envisaged a new kind of history textbook and at the end of the war assembled a team of specialist advisers and wrote his Plain History of Life and Mankind, The Outline of History (1920). This brought him new fame and he used this in his activities as a propagandist and commentator on world order. His favourite project was an 'Open Conspiracy' to work towards world peace and global reorganisation. George Orwell and others later accused him of political naivety although he had tapped a popular yearning for a stable world order not too dissimilar to the philosopher-king Keynes had alluded to. ${ }^{44}$ Unfortunately for Europe '[Wilson] was not the philosopher-king' that was expected and needed' to enable such an order to be established ${ }^{45}$

\subsubsection{Religious Imagery}

Disappointed expectations in the leader's performance at the Conference is a theme that runs through Economic Consequences. As well as Keynes' use of metaphors and allusions to the classical world and analogies to Napoleon as ways of comparing and contrasting the failings and weaknesses of the political leaders at Versailles, Keynes uses religious imagery, especially from the Judaeo-Christian tradition, to emphasise his disappointment with Allied leadership. Keynes' use of religious imagery expands on three broad themes. First is the confusion among the leaders at the Conference. Second, the deception of the leaders, especially during framing of the Treaty. Third the theme of weakness is highlighted using religious imagery.

In the first of these themes (confusion) Keynes alludes to 'a babel of sound' that left 'a most vivid impression' on Keynes during his own attendance at the Conference. ${ }^{46}$ The source of the word babel comes from the Book of Genesis and the story of the Tower

\footnotetext{
${ }^{44}$ Parrinder, (ONDB, 2004, 36831).

${ }^{45}$ Keynes, (1919, p. 38).

${ }^{46}$ Keynes, (1919, p. 28).
} 
of Babel, built as the crowning achievement to the city of Babylon. ${ }^{47}$ According to the biblical account Babylon was a city that united humanity, all speaking a single language and was the home city of the great King Nimrod and the first city to be built after the great flood. Whereas the Tower of Babel's purpose was for the worship and praise of God, it rather became dedicated to the glory of man. God, seeing what the people were doing, gave each person a different language to confuse them and scattered the people throughout the earth. Similarly the globalised world of pre-World War One Europe had diverged into the "worship and praise" of nationalism and imperialism. When world leaders gathered at Versailles to attempt returning the world to stability and unity, they instead could not move beyond the babel of different languages and competing selfinterests, leaving a vivid impression on Keynes as he observed 'a surging mob' crowded around Wilson, Lloyd George and Clemenceau offering up 'a welter of eager, impromptu compromises and counter-compromises, all sound and fury signifying nothing, on what was an unreal question anyhow, the great issues of the morning's meeting forgotten and neglected. ${ }^{48}$ The reference to 'all sound and fury signifying nothing' is an allusion to Shakespeare's play Macbeth and Macbeth's soliloquy in Act 5 Scene 5:

And then is heard no more. It is a tale

Told by an idiot, full of sound and fury, Signifying nothing.

Keynes found religious imagery useful when discussing what he considered the most deceptive aspect of Versailles. Scandalously, politicians who had gathered to restore stability and prosperity to Europe were doing anything but restoration work. Rather, they were going down a path opposite to what could be considered by the average person to

\footnotetext{
${ }^{47}$ Genesis 11: 1-9.

${ }^{48}$ Keynes, (1919, p. 28).
} 
be 'normal, certain, and permanent.' Many of the decisions taken at Versailles were 'the projects and politics of militarism and imperialism, of racial and cultural rivalries, of monopolies, restrictions, and exclusions.' Keynes argued that these projects and politics 'were to play the serpent to this paradise of normality, certainty and permanence. ${ }^{49}$ Through the seductive actions of their leaders the innocent 'average person' would suffer the consequences in the same way Adam and Eve paid the price for eating the forbidden fruit from the Tree of the Knowledge of Good and Evil when cast out of the Garden of Eden (a prosperous and stable Europe). ${ }^{50}$

Keynes extends his criticism of the political leaders deception to those serving the politicians - the officials, lawyers, and draftsmen responsible for framing the Treaty. These individuals were 'the subtlest sophisters and most hypocritical draftsmen [who] were set to work, and produced many ingenious exercises which might have deceived for more than an hour a cleverer man than the President. ${ }^{, 51}$ Keynes once again used religious symbolism to make his point. He used President Wilson as his starting point for criticising the politicians 'servants' who came to the Conference committed to the Fourteen Points. These Fourteen Points, argued Keynes, were as sacred as the Pentateuch is for the Jewish people and the legal and ethical principles all Jews are expected to live by. This sacred text, known as the first five books of Moses in the Old Testament (Genesis, Exodus, Leviticus, Numbers and Deuteronomy) is also referred to as the Torah.

Keynes' real issue and criticism was the manipulative interpretation of the Fourteen Points. The Fourteen Points (Pentateuch) remained sacred to the President but in the hands of the lawyers and officials charged with interpreting the them 'they became a document for gloss and interpretation and for all the intellectual apparatus of self-

\footnotetext{
${ }^{49}$ Keynes, (1919, p.10).

${ }^{50}$ Genesis 3: 14-24.

${ }^{51}$ Keynes, (1919, p. 47).
} 
deception.' It was then just a short step to 'the weaving of that web of sophistry and Jesuitical exegesis that was finally to clothe with insincerity the language and substance of the whole Treaty. ${ }^{52}$ Here Keynes refers to experts, using the analogy of the Jesuits, who gave propagandist treatment to the text of the Treaty (exegesis or critical examination of a text). ${ }^{53}$ By way of example Keynes used the prohibition of Austria uniting with Germany to make his point:

Thus instead of saying that German-Austria is prohibited from uniting with Germany except by leave of France (which would be inconsistent with the principle of self-determination), the Treaty, with delicate draftsmanship, states that "Germany acknowledges and will respect strictly the independence of Austria, within the frontiers which may be fixed in a Treaty between the State and the Principal Allied and Associated Powers; she agrees that this independence shall be inalienable, except with the consent of the Council of the League of Nations," which sounds, but is not, quite different. And who knows but that the President forgot that another part of the Treaty provides that for this purpose the Council of the League must be unanimous. ${ }^{54}$

In this example we see two "ugly" aspects of the Treaty's deception. First, those behind the framing of the Treaty have convinced themselves that wrong is right and second, because of their actions everything around them is corrupted. Keynes sums up the deception with an analogy from Shakespeare's Macbeth:

The word was issued to the witches of all Paris:

\footnotetext{
52 Keynes, (1919, pp. 46-47).

${ }^{53}$ The Jesuits, or The Society of Jesus, is a religious order of men who follow the teachings of the Catholic Church. They have a reputation for works in the field of education and intellectual research. However, they also undertake missionary work, promote social justice, conduct hospital and parish ministry and encourage ecumenical dialogue. They will also often act as apologists for the Catholic Church's interpretation of religious and humanitarian texts and documents. Refer to Ginzburg, (c1999).

${ }^{54}$ Keynes, (1919, pp.47-48).
} 
Fair is foul, and foul is fair,

Hover through the fog and filthy air. ${ }^{55}$

Shakespeare's play highlights how desire can overwhelm people so they become oblivious to what may be "foul" or bad. Lady Macbeth's fair appearance was the exact opposite of her intentions and personality. Similarly, the Allies came to the Conference appearing to uphold the principles of the Fourteen Points when in fact their intentions were to destroy a beaten foe, regardless of the consequences (desire for revenge overwhelmed their principles). Desire is also at the root of greed and foulness and nothing is what it seems. When the witches chant 'fair is foul and foul is fair' similarly the greed and desire of the victorious Allies is foul as they sought to impose impossible terms on Germany. Furthermore they were foul in their clear deception for saying one thing (to uphold the Fourteen Points) and doing another (imposing terms intended to destroy Germany economically). Another interpretation of Macbeth involves religious imagery. That is, there is a school of thought a Christian interpretation can be put onto the phrase 'fair is foul and foul is fair' to describe those who worship Satan with the phrase itself describing ultimate truth. ${ }^{56}$ That which makes a human fair (virtue) is foul (vice) and that which makes a human foul (vice) is fair (virtue). The witches serve evil and they declare so with the phrase. Taking this interpretation Keynes accused all those who were complicit in the framing and execution of the Treaty to be serving evil.

As repugnant as this may seem Keynes argues there is an explanation for the evil and deception in Paris. These were the "false idols" of nationalism that possessed the European family during the war. Despite the efforts of the President of the United States, these false idols had taken possession of the leaders of the European nations in the same way in which the Jewish people had started worshipping the false idols of paganism in

\footnotetext{
${ }^{55}$ Keynes, (1919, p. 47).

${ }^{56}$ Anderson, (2003).
} 
place of the "truth" of monotheism. ${ }^{57}$ By likening the European family to worshippers of false idols Keynes was pointing out that Europe had turned its back on the "truth" ('of a policy of reconciliation') that had been embraced by the United States and some European countries. He called for the United States to not lend 'a penny to a single one of the present Governments of Europe' until such time as they gave up the worship of the "false idols" of hatred and nationalism. ${ }^{58}$

To Keynes it was clear who was responsible for the worship of false idols, just as there was an explanation for the deception and the 'general upheaval and disorder' that found expression in a babel of sound and confusion. All, argued Keynes, were symptoms of weak leadership, especially that of President Wilson. Keynes used three unrelated examples to support his views. First he focuses on the nature of President Wilson's charisma, or, as in this case, lack of it. Keynes had already stated Wilson was not the philosopher-king but does contend that he was a man of force, personality, and importance. But, asks Keynes, what of his temperament?

The clue once found was illuminating. The President was like a Nonconformist minister, perhaps a Presbyterian. His thought and his temperament were essentially theological but not intellectual, with all the strength and the weakness of that manner of thought, feeling, and expression. It is a type of which there are not now in England and Scotland such magnificent specimens as formerly; but this description, nevertheless, will give the ordinary Englishman the distinctness impression of the President. ${ }^{59}$

In short, Wilson was a rather dour, uncharismatic dogmatic leader, who reminded Keynes more of a preacher than a political leader of men who, as a Nonconformist minister could

\footnotetext{
${ }^{57}$ Exodus 32: 1-24.

${ }^{58}$ Keynes, (1919, p. 267).

${ }^{59}$ Keynes, (1919, p. 38).
} 
not compromise. Keynes was appealing to a stereotype that associated Scottish

Presbyterianism with a style of religion which was considered serious to the point of being bleak and dull. Furthermore, Keynes argues that Wilson did not grasp European affairs. When Keynes says '[Wilson] could have preached a sermon on any of them or have addressed a stately prayer to the Almighty for their fulfilment, ${ }^{60}$ he brings to mind Abraham Lincoln's phrase to describe Americans as "the almost chosen people." ${ }^{61}$ This is a phrase that sums up the uneasy relationship between the American republic and the religious spirit of its people. Europeans are often struck by the way in which high church attendance, and overt religiosity, coexists with the passionate pursuit of materialism. For Keynes this explained why Wilson sounded so plausible in speeches and in his Notes before coming to the Conference. He seemed to have a 'Programme for the World.' However, on setting foot in Europe '[Wilson] had no plan, no scheme, no constructive ideas whatever for clothing with flesh of life the commandments which he had thundered from the White House.' The President 'could not frame their concrete application to the actual state of Europe' because he did not understand Europe as being different from the United States. ${ }^{62}$

Another use of religious imagery is the sense of unreality defining Wilson's leadership. While Wilson made all the right noises he, in reality, had no idea how to address the problems of Europe because, according to Keynes, he had no capacity to understand a culture that was not American and he was too dogmatic to know how to

\footnotetext{
${ }^{60}$ Keynes, (1919, p. 39).

${ }^{61}$ President-elect Abraham Lincoln spoke separately to each branch of the New Jersey legislature on his inaugural journey to Washington. In the Senate he referred to Trenton's Revolutionary War heroics and spoke of himself as a "humble instrument in the hands of the Almighty, and of this, his almost chosen people, for perpetrating the object of that great struggle." Trenton, New Jersey, February 21, 1861. Source: "Abraham Lincoln Speeches and Writings," 
seek compromise among fellow statesmen. Keynes once again uses a metaphor to explain what he means: '[Wilson] could write Notes from Sinai or Olympus. But if he once stepped down to the intimate equality of the Four, the game was evidently up. ${ }^{63}$ The phrase 'notes from Sinai or Olympus' relates to an ancient view of human civilization that believed flight was a privilege reserved only for the gods whose abodes were in "high places." The Greeks placed their pantheon on Mt. Olympus and warned of the hubris mere mortals displayed in attempting to go there. Thus, Icarus soared on the waxy wings crafted by Daedalus until he dared approach the Sun and fell to his death.

In reference to Sinai Hebrew texts place the Lord "up there." He led his people as a pillar of cloud or light and met with Moses on the top of Mt. Sinai. On descending from the heavens Moses found his followers had turned to worshipping a golden calf (false gods). What this says of Wilson, according to Keynes, is that Wilson seemed at home in the ideal world conversing with 'the Lord' on Mt. Sinai and could preach on the abode of the gods on Olympus but when he had to deal with the concrete realities of leadership 'the game was effectively up.' Like Icarus, Wilson's hubris brought him crashing back to the realities of the earthly world and like Moses, Wilson was so wrapped up in the ideals of the Fourteen Points, he failed to see those that he was appointed to lead were worshipping the false gods of nationalism and self-interested revenge.

Keynes came in for considerable criticism for his unflattering portrait and judgment of Wilson, especially in the US. Certainly Keynes failed to acknowledge the serious political difficulties Wilson faced back home. Despite winning the Nobel Peace Prize in 1919, for his efforts at Versailles, Wilson could not win US Senate support for ratification of the Treaty and the US never joined the League of Nations, which Wilson had first proposed as part of his Fourteen Points on January 8, 1918. After the US elections during December 1918 Republicans controlled the Senate but Wilson refused to agree to proposed changes put

${ }^{63}$ Keynes, (1919, p. 46). 
forward by the Republicans in regard to the Fourteen Points. He also became less trustful of the press and stopped holding press conferences. ${ }^{64}$ Following Wilson's serious stroke on October 2, 1919 Keynes heeded the advice of friends and toned down his portrayal of Wilson. However, it was still highly critical of Wilson and Keynes' flamboyant style no doubt fanned the flames of criticism.

\subsubsection{Referencing Other Literary Sources}

In addition to using religious imagery when discussing Wilson, Keynes also likens Wilson to a 'blind and deaf Don Quixote, ${ }^{65}$ the reference intended as something more than just a comment on Wilson's incompetence. By referring to Don Quixote Keynes is referring to the theme of deception, bringing this and weak leadership together as the twin evils of the Conference. Keynes does this by comparing the behaviour of Lloyd George to that of Wilson. Keynes argued that '[Wilson] was not only insensitive to his surroundings in the external sense; he was not sensitive to his environment at all. What chance could such a man have against Mr. Lloyd George's unerring, almost medium-like, sensibility to everyone immediately round him $?^{66}$ Whereas Wilson had come to Versailles to build on the principles of the Fourteen Points Lloyd George played the part of the consummate politician who, on the one hand appeared to support Wilson's principled approach but in reality was playing to an electorate audience back home in Britain. Lloyd George had taken a mental note of the anti-German sentiment summed up in the words 'we will squeeze Germany like a lemon until you can hear the pips squeak' and did not plan to lose an election when he got home by being judged as being 'soft' on Germany. ${ }^{67}$ But his was

\footnotetext{
${ }^{64}$ Rouse, (2006).

${ }^{65}$ Keynes, (1919, p. 38). The novel Don Quixote was published in two parts, Part 1 in 1605 and Part 2 1614, under the authorship of Miguel de Cervantes Saavedra.

${ }^{66}$ Keynes, (1919, p. 37).

67 This phrase is from a speech by Sir Eric Geddes (1875-1937), British Conservative politician, in December 1918 at the Guildhall in Cambridge and became an infamous summary of how many in Britain (and shared ...Footnote continued on next page...
} 
a personal dilemma. He had been a key partner in drawing up the Fourteen Points, persuading Germany to lay down arms and enter negotiations for Peace on a good faith basis. But if it troubled Lloyd George the leaders had deceitfully broken their promises outlined in the Fourteen Points it did not show. Keynes argued, he was able to outwit the other leaders at the Conference by, on the one hand, appearing to side with Wilson in supporting the Fourteen Points principles while on the other being a party to the deception of the Treaty. Keynes argued:

To see the British Prime Minister watching the company, with six or seven senses not available to ordinary men, judging character, motive, and sub-conscious impulse, perceiving what each was thinking and even what each was going to say next, and compounding with telepathic instinct the argument or appeal best suited to the vanity, weakness, or self-interest of his immediate auditor, was to realize that the poor President would be playing blind man's buff in that party. ${ }^{68}$ Never could a man have stepped into the parlour a more perfect and predestined victim to the finished accomplishments of the Prime Minister. ${ }^{69}$

Deception came easily to Lloyd George; it might be argued that for a politician it was one of his strengths. But, taken together with Wilson's weakening leadership it meant any good intentions were undermined. These were the twin evils of the Conference.

Keynes deals with these themes of weakness and deception in one of his more colourful allusions, this time to the Anti-Christ, when referring to the British election of

by her close allies) felt about how revenge through reparations should be exacted on Germany. Keynes called it a 'gross spectacle' (Keynes, (1920 p. 131)). The actual phrase used by Geddes was, "We will get out of her all you can squeeze out of a lemon and a bit more. I will squeeze until you can hear the pips squeak." Grieves, (ODNB, 2004, 33360).

${ }^{68}$ Blind man's buff is a children's game played as far back as Tudor times although it was a popular game in the Victorian era. The game is a variant of tag. Buff means small push but it may originate from the older sense of bluff meaning to blindfold.

${ }^{69}$ Keynes, (1919, pp. 37-38). 
December 1918. He claimed that 'a vote for a Coalition candidate meant the Crucifixion of Anti-Christ and the assumption by Germany of the British National Debt. ${ }^{70}$ Lloyd George's National Coalition swept to power on the populist sentiment that the Allies would 'make Germany pay.' Keynes, however, believed Lloyd George to have deceitfully appealed to this populist sentiment because Lloyd George did not believe Germany could pay the whole cost of the war. However, the British people, like their European allies, were in no mood for showing weakness towards Germany on the issue of making her pay the full cost of the war's destruction. Lloyd George was happy to oblige and during electioneering did not provide any public display around doubts about Germany's ability to pay.

There are two possible meanings to be taken from this allusion. The first relates to the Anti-Christ of the Bible. The name itself is only found in 1 John 2:18, 2:22, 4:3 and 2 John 7 and refers to the warnings that many anti-Christ's or false teachers will appear between the time of Christ's first and second coming. In the last hour one great Anti-Christ will arise to power and deny that Jesus is Christ. The Anti-Christ is a liar and deceiver. If we apply this to Keynes' use of the term he would be saying 'a vote for a Coalition candidate meant Crucifixion of the lies and deception around making Germany pay the full cost of the war.' However, Keynes' gives the reference an opposite meaning. The Coalition, under Lloyd George's leadership, was being deceitful so 'the Crucifixion of Anti-Christ' must mean something else. The most likely explanation is that Keynes was referring to Friedrich Nietzsche's book The Anti-Christ originally published in 1895. We know the works of Nietzsche were discussed by Keynes' Bloomsbury circle because they are referred to in the archives that survive. For example, Virginia Woolf wrote '... Nietzsche sent waves of fresh thought across the Continent. ${ }^{, 71}$ The title of Nietzsche's book, from the German title, can also be translated into English, as "The Anti-Christian" for this is the subject of his book.

\footnotetext{
${ }^{70}$ Keynes, (1919, pp. 132-133).

${ }^{71}$ Holroyd, (1995, p. 305)
} 
Nietzsche argued that Christianity had weakened the human will and his books, as with much else to do with his religious thinking, prophesied that as Christianity was rejected in favour of secular man, mankind could reclaim a strength of will that Christianity had suppressed for so long. The Anti-Christian is the opposite type of person to the person who follows Christianity's teachings. Nietzsche blamed Christianity for demonising strong, higher humans. The Anti-Christ had broken free from centuries of the christianisation of mankind that had bred weak, sickly humans. Thus, when Keynes refers to Crucifixion of the Anti-Christ he is referring to the Crucifixion of the strength of will that knew the right thing was not to penalise Germany to the detriment of the whole of Europe. Instead, those who voted for a Coalition candidate were supporting the deceitful stance that Germany should pay in full and hence Keynes' words 'Germany would assume the British National Debt.'

The reference to Nietzsche is an interesting one as Nietzsche's views, were at this time, out of favour with many of Keynes' intellectual contemporaries. For example, Thatcher in his book Nietzsche in England: 1890-1914 cites Leonard Woolf at this time as saying "Nietzsche was practically ignored by almost everyone known by me in the last seventy years, and I cannot even remember a discussion about him." On the other hand, an older member of Bloomsbury, Desmond MacCarthy, wrote reviews of Nietzsche, praising his exultant courage, his buoyant scepticism and his ruthless honesty. ${ }^{72}$ Not that Keynes own views of Nietzsche are relevant for this discussion; what is necessary to establish is that Keynes would have been aware of the works of Nietzsche because others in Bloomsbury were.

Taking the two allusions together, Don Quixote and the Anti-Christian, Wilson was a weak and incompetent leader, bested by the duplicitous Lloyd George. While Lloyd George appeared to Wilson to be an ally in upholding the principles of the Fourteen

\footnotetext{
72 Thatcher, (1970, p. 267).
} 
Points, Lloyd George had in fact been deceitful by undermining Wilson's views. He had also gone a step further than being deceitful by defeating the principled Wilson in a battle Wilson had no idea he was fighting for. In this battle 'the Old World was tough in wickedness anyhow; the Old World's heart of stone might blunt the sharpest blade of the bravest knight-errant. But the blind and deaf Don Quixote was entering a cavern where the swift and glittering bade was in the hands of the adversary. ${ }^{73}$

The reference to a blind and deaf Don Quixote entering a cavern is itself significant. While the structure of Don Quixote is episodic and farcical, in itself a commentary of how Keynes felt about the Conference, the second half of the book is serious and philosophical about the theme of deception, exactly the theme that Keynes argues underpinned the actions of the Allied participants. Furthermore, Quixote's adventures tend to involve situations in which he attempts to apply a knight's sure, simple morality to situations in which much more complex issues are at hand. The very situation, argued Keynes, Wilson found himself in. In the same way Don Quixote enters a cavern in one of his adventures, without knowing what he is walking in to, makes him figuratively blind and deaf. Similarly a 'blind and deaf' Wilson enters into the Conference proceedings thinking that he was acting as an honourable knight when in reality he is caught up in a farcical adventure.

In the same way Keynes uses phrases from Don Quixote to highlight themes of deception, incompetent leadership and farce, he makes reference to another well-known literary phrase 'the Immanent Will' to argue there are serious consequences resulting from the deception, incompetent leadership and farce that came to define the Conference and resulting Peace Treaty. The term was first used by Thomas Hardy (1840-1928) in his poem of the Titanic tragedy "Convergence of the Twain - Lines on the loss of the

\footnotetext{
${ }^{73}$ Keynes, (1919, p. 38).
} 
Titanic." ${ }^{74}$ Kipling had earlier put the word twain ${ }^{75}$ on the poetic map with one of his Barrack-room Ballads in 1892, declaring, "Oh, East is East, and West is West, and never the twain shall meet." Kipling's use of the word describes an imperial West he cannot imagine has any connection with the East. Similarly Hardy's view of the sinking of the Titanic is such an overwhelming and unimaginable possibility that "the twain has converged." The twain for Hardy refers to the "collision" of the Titanic and the Immanent Will 'that stirs and urges everything prepared a sinister mate for the ship: "a Shape of Ice."'76 In Hardy's world view, the twain meet in time and space when the "spinner of Years said 'Now!' And each one hears, and consummation comes, and jars two hemispheres." The "Immanent Will" or fate or chance said "Now!" and the Titanic was hit. This turns out to be a sinister mate. The extent of the injury from the impact is not immediately known (surely, there are 16 watertight compartments?) ${ }^{77}$ But slowly the passengers realise things are amiss, and then rapidly they are sinking. In the same way the Immanent Will at play in the tragedy of the Titanic was at play during the Conference proceedings. Similarly most of the characters in Hardy's books fight a losing battle against the impersonal forces of fate, the hand of fate may usher in another revolution that no statesman, politician or intellectual on their own can do anything about. Nothing could be done once fate (the Immanent Will) moved to sink the Titanic. This 'inevitable' powerlessness of individuals to hold back the tragedy of revolution, just as the passengers

\footnotetext{
${ }^{74}$ Dean, (1912).

${ }^{75}$ from Old English twegen, meaning two.

${ }^{76}$ From verses VI and VII of Thomas Hardy's The Convergence of the Twain. The sinister mate refers to the iceberg the Titanic hits ('A Shape of Ice') and is comparing the beauty and grace of the Titanic joining with the iceberg that becomes her undoing.

${ }^{77}$ There were 16 main compartments of the Titanic. The double bottom was 7 feet high and divided into 44 watertight compartments. There were an additional 13 small compartments above the tank top. This knowledge entered the public consciousness following the testimony of Edward Wilding, Naval Architect with Messrs. Harland and Wolff at the British Wreck Commissioner's Inquiry into the sinking of the Titanic. Wilding's testimony was given on Day 18, 30 July 1912.
} 
on the Titanic were powerless to stop her sinking, is reinforcement of Hardy's view that human downfall is the result of an unwilling conflict with a hostile, meaningless universe. Should revolution, as predicted by Keynes, be a result of the Treaty, there is little, if nothing, individuals can do to prevent it. 


\subsection{Prose and Style - Summary}

What is striking about Keynes' prose style is his rich use of metaphors, including allusions and analogies, which rarely feature in works of economics. First, the entire book is underpinned by a genre of prophetic and apocalyptic writing. Keynes draws on the works of Wordsworth's The Excursion Book Third to paint an apocalyptic picture of the failure of statesmen and politicians to grasp the economic destruction they are about to unleash on Europe. He uses the same apocalyptic imagery to chasten the "great capitalist class" of Europe whom he holds responsible for not doing enough to restore Europe's economic fortunes. Dramatically Keynes finishes Economic Consequences with a lengthy citation from Shelley's Prometheus Unbound. Yeats had also used Shelley's poem in his The Second Coming and with Keynes believed the world was on the threshold of an apocalyptic moment. Both had a vision of destruction that would be rendered by "the beast" although they differed in their views of how things would play out. Yeats held the view that further destruction was necessary to enable proper restoration, whereas Keynes took no satisfaction from the thought of more destruction. Rather he believed reform and change could overcome the nightmare of a looming apocalypse.

Within this apocalyptic framework, Keynes draws out a number of significant themes. He uses analogies and the allusion of Napoleon and Spartacus as ways of developing three important themes of failed leadership. First are the weak and impotent leaders who failed to find effective economic solutions. Second, there was disappointment in the Allied leaders. Wilson, in particular, like Napoleon, was a leader with great promise who ultimately greatly disappointed. Finally, Keynes used the character of Napoleon to highlight the problems of re-building the economies of both Germany and Russia in the face of the possibility of another Napoleon-like domination of Europe.

Another effective use of metaphor is Keynes' allusions to the Classical World. He compares Clemenceau's misplaced love of France to Pericles' love of Athens. In the same way as this spelt doom for Pericles and Athens, Keynes argued that Clemenceau's desire for revenge would spell doom for France. The Carthaginian Peace was a term first coined 
by Keynes and subsequently has become the term often used to describe the Treaty. The destruction of Carthage by the Romans was total and Keynes prophesied Europe's destruction would be equally terminal should the Treaty terms be imposed. ${ }^{78}$ Finally, Keynes argued that such an apocalyptic vision could be averted with strong leadership, especially from the United States. His analogy of the philosopher-king, who could ensure world order, was still possible, although Keynes had doubts, for Wilson was no philosopher-king.

As well as allusions to the Classical World Keynes used religious imagery, especially Judaeo-Christian imagery, to focus attention on the failures of the Allied leadership. First, Keynes likens the confusion at the Conference to the biblical story of the Tower of Babel. He used this imagery to demonstrate how competing self-interest and the worship of nationalism and imperialism are major impediments to the restoration of prosperity. The second failure that concerned Keynes was the role deception played in drafting the Treaty. He compares the actions of those responsible to the serpent in the Garden of Eden who seduced Adam and Eve to deceive God. Europe's punishment would be a failure to return to prosperity and stability in ways similar to Adam and Eve having been cast out of the Garden of Eden and destined for a life of hardship. Furthermore, Keynes compares the sacred books of the Pentateuch to the sacredness of the Fourteen Points and then used the analogy of the Jesuits, scholarly experts and apologists for Catholicism, to argue experts who framed the Treaty gave it propagandist treatment. Keynes then deals with two ugly aspects of the Treaty's deception. First, those who framed the Treaty convinced themselves that, like the witches from Shakespeare's Macbeth, right is wrong and wrong

\footnotetext{
${ }^{78}$ One of the subsequent criticisms of Keynes' argument was that even though he was right about another European 'civil revolution' (World War Two) Europe not only survived the war but went on to prosper economically, hardly a Carthaginian outcome. However, what this criticism overlooks is that the Treaty terms were never imposed in the ways intended at Versailles. While the term Carthaginian Peace is probably a good example of Keynes' exaggerated prose, designed to shock his readers, we literally do not know if Europe would have been reduced to a second Carthage.
} 
is right (fair is foul and foul is fair). Another interpretation is, those who worship Satan invert fair (virtue) with foul (vice) so those complicit in framing the Treaty were serving evil. This evil and deception, argued Keynes, was due to the worship of the false idols of nationalism.

Keynes has an explanation for the deception, which is the evil worship of false idols enabled by weak leaders at the Conference, especially Wilson. Keynes used three examples to illustrate what he meant. First, Wilson did not grasp European affairs and as an American was blinded by what Abraham Lincoln had called "the almost chosen people." Second, Wilson's dogmatic personality and lack of capacity to understand European affairs is likened to the hubris of Icarus and the unreality of conversing with the Lord on Mt. Sinai, while those he should be leading are worshipping the false gods of nationalism and self-interested revenge.

In addition to religious imagery, Keynes refers to other literary sources in support of his arguments. He likens Wilson to a blind and deaf Don Quixote. This is more than a reference to Wilson's incompetence; it also refers to deception and weak leadership, what Keynes labelled as the twin evils of the Conference. In developing the theme of deception, Keynes referred especially to Lloyd George, who had the better of Wilson in a game of blind man's buff. In dealing with these twin themes, Keynes refers to the Anti-Christ, by Nietzsche. When Keynes speaks of the crucifixion of the Anti-Christ he means the crucifixion of the strength of will that knew the right thing to do was to not penalise Germany in ways that would penalise all of Europe. Keynes also draws on Quixote again to make his point that deception tainted the entire Conference. Wilson entered Paris thinking he was an honourable knight, when in reality he is caught in a farcical adventure. Similarly, Keynes draws on Hardy's concept of Immanent Will to highlight the themes of deception, incompetence and farce. He uses Hardy's poem “Convergence of the Twain Lines on the Loss of the Titanic" to argue that in the same way the Immanent Will meant the sinking of the Titanic was inevitable, it was inevitable Europe was marching toward further upheaval, instability and revolution that would leave Europe economically destitute. This created in Keynes a feeling of despair, yet, despite the dark and ominous 
tones he finished Economic Consequences on an optimistic note. He offered a set of economic solutions to replace the Treaty terms, which could head off the possibility of war and economic hardship. Finishing with Shelley's Prometheus Unbound is a signal that in the same way as Shelley saw this as the answer to the mistakes of the French Revolution, Keynes believed a different approach and set of measures could restore economic prosperity and address the consequences of the Carthaginian Peace. 


\section{Chapter 7. Influences on Keynes' Style}

There were two significant literary influences on Keynes' writing style, his friendship with Lytton Strachey and his association with Virginia Woolf. Economic Consequences closely maps aspects of both Strachey's and Woolf's styles. A comparison of Strachey's Eminent Victorians and Economic Consequences shows how both men often used triplets to construct words, sentences and phrases. There is a literary tradition of using triplets reaching back to ancient Greece and Rome. Two explanations can be given for its popularity with some writers. First, triplets can help clarify an author's meaning. Second, they help elaborate. This enhancement to prose style was something Strachey particularly excelled at and Keynes sought to imitate. A primary influence on Strachey had been Gibbon's Decline and Fall of the Roman Empire and Gibbon was also prone to using triplets. Gibbon also provided another important influence, which has had a lasting effect on all historians and biographers since. He applied a disciplined approach to his research and a veracity to his naming of sources not previously undertaken by historians.

Both Strachey and Keynes owed a great deal to these conventions of the past. Nevertheless they were not bound by the past and both pioneered innovative new ways of writing biography and economics respectively. Their use of elaboration and exaggeration in the hands of lesser talents could easily have become tedious but as skilled rhetoricians both men chartered new ways of writing. In looking for explanations, some critics argue their homosexuality partly accounts for their unique styles. This is a controversial argument and does not enjoy widespread support, but at a time when some aspects of sexual orientation were criminalised, a sense of rebellion and elaboration permeates literary styles often not found in writers whose sexuality is not suppressed or hidden in some way. However, both men enjoyed entertaining their readers and they both took pleasure from shocking their readers so it is not surprising they believed their point of difference was because they were "rebellious immoralists." 
A second important influence on Keynes' style was Virginia Woolf and her interest in psychological realism. Woolf was also an innovator and she developed the inner psychology and complex personalities of her characters in ways previously not done. This also coincided with a period when there was great interest in the developing discipline of psychology by fellow Bloomsberries and a comparison of the three writers' treatment of their characters shows a similarity of style when it came to dealing with the inner psychology of their subjects. Such a comparison lacks explicit verification but an examination of the archives reveals how important, and with regularity, each author took an interest in the other's writing. For example Keynes and Strachey regularly swapped books and manuscripts, also corresponding and commenting on each other's views. Woolf also wrote to Keynes on one occasion commenting on his reading out a portion of his unpublished manuscript of Economic Consequences to a group of Bloomsberries. Letters also reveal Keynes and Strachey discussed and compared their respective works in progress. By implicit methods we can see how important the influences on each other were. 


\subsection{Lytton Strachey's Eminent Victorians}

Quoting David Garnett, ${ }^{1}$ Michael Holroyd claimed Strachey's Eminent Victorians 'was to influence the style of Economic Consequences of the Peace .... persuading Keynes to be more indiscreet than he was by nature and to have the courage to print what he would have said in conversation. ${ }^{2}$ Given the close friendship of Strachey and Keynes up to the time of publication of both Eminent Victorians (1918) and Economic Consequences (1919) Holroyd's claim would be difficult to refute. ${ }^{3}$ However, Holroyd provides little material to enable judgment on the degree to which Strachey's style in Eminent Victorians influenced Keynes' style in Economic Consequences. Rosenbaum has no doubt there is a strong correlation between both men's styles, albeit poorly researched to date. ${ }^{4}$ Furthermore, Rosenbaum argues, those associated with the Bloomsbury set and literary works produced by Bloomsberries have a close reciprocal relationship. ${ }^{5}$ Rosenbaum also argues that 'the basic premise of a literary history of the Bloomsbury Group is that their writings are historically interrelated in ways important if not essential to their interpretation. ${ }^{6}$ In

\footnotetext{
${ }^{1}$ Garnett, (1979, p. 140) from Holroyd, (1995, p. 428).

${ }^{2}$ Holroyd, (1995, p. 428).

${ }^{3}$ For a period of time Strachey and Keynes were the 'effective' leaders of the Cambridge Apostles and their correspondence during this time is voluminous, rich in detail, at times very personal and at other times, engaging in gossip that only close friends would exchange. Following graduation from Cambridge Strachey and Keynes remained close friends through their association with the Bloomsbury set that continued, albeit not as intensely during the Apostle days, up until the mid-1920s.
}

${ }^{4}$ Some scholars have looked closely at the prose styles of individuals within Bloomsbury. For example Barry Spurr has written a book and journal articles dealing specifically with Strachey's prose style. Refer: Spurr, (1995), and Spurr, (1990). However there is little in the way of comparative analysis between the Bloomsbury friends and the degree of influence each other's writing styles had on the others.

${ }^{5}$ Rosenbaum, (1981, p. 330). Rosenbaum uses Leonard Woolf as the 'most detailed and reliable historian of the group' to establish the original members of the Memoir Club (Bloomsbury core members) as Leonard and Virginia Woolf, Vanessa and Clive Bell, Lytton Strachey, Maynard Keynes, Duncan Grant, Roger Fry, Mary and Desmond MacCarthy, E. M. Forster, Saxon Sydney-Turner, and Adrian Stephen.

${ }^{6}$ Rosenbaum, (1981, p. 331). 
commenting specifically on Keynes' Economic Consequences and Strachey's Eminent Victorians, Rosenbaum claims the entire texts of both works are related to each other and adds that 'Bloomsbury's writings display ... similarity [in such a way that] ... literary history [calls for a description of] ... this resemblance.' ${ }^{7}$

\subsubsection{Triplets and Style}

Spurr notes that in Strachey's book there is a persistent use of triplets in words, sentences and phrases, something that literary critics of Economic Consequences have also noticed in Keynes' book. Furthermore, there is often a pattern of both writers using a triplet of words, followed by a set of phrases in triplet, and finally three sentences that taken together form a triplet. Spurr refers to this characteristic of Strachey's style as his 'elaboration of phraseology' and that his use of triplets of words, phrases, and sentences 'in an immense variety of guises is the most extraordinary manifestation of this preoccupation. $^{\prime 8}$ Strachey's and Keynes' use of triplets is unusual for writers of the 'modernist' period although it does enjoy a rich history of usage, especially from the medieval English and Restoration periods, when writers looked back to a Latin tradition for rhetorical inspiration.

This Latinate influence has not always enjoyed scholarly support. For example, Burnley points out it has only been since the late 1970s that literary critics have increasingly come to support the view that the use of triplets in prose writing owes more to Latin influences than French-Anglo writing. ${ }^{9}$ Furthermore, Burnley argues, the curial

\footnotetext{
${ }^{7}$ Rosenbaum, (1981, p. 338).

${ }^{8}$ Spurr, (1990, p. 36).

${ }^{9}$ Burnley, (1986, p. 593) from Diane Bornstein, (1977), "French Influence on Fifteenth-Century English Prose as Exemplified by the Translation of Christine de Pisan's Livre du Corps de Policie," Mediaeval Studies, 39, pp. 369-386; and (1978), "Chaucer's Tale of Melibee as an example of the Style Clerigial," Chaucer Review, 12, pp. 236-254 as evidence that Chaucer had used the curial prose style some 100 years before William Caxton. Until then it had been assumed that Caxton pioneered the style and had learned it from French courtly models. However, evidence of Chaucer's use of the style supports the view that it has Latin roots and Latin ...Footnote continued on next page...
} 
style of prose used in England from the time of Chaucer 'with its Latinate constructions, extensive clausal qualifiers, lexical doublets and triplets, and anaphoric cohesive devices, ${ }^{10}$ supports the view that triplets were used as rhetorical devices as far back as ancient Roman times, ${ }^{11}$ with a renaissance in their use taking place during the medieval English period. Research by Politzer, whose work predates that of Bornstein by sixteen years ${ }^{12}$ supports the view that triplets can be traced to 'learned Latin rhetoric' and the use of the device 'mushroomed' in the early Middle Ages. ${ }^{13}$ Vos' study of Ascham's (c. $1515-$ 1568) prose style supports the view that the use of triplets became popular during the Middle Ages, and also notes the important influence of Cicero's (Latin) style on Ascham.

From around the time of the Restoration period to the late 1700 s use of the triplet style was increasingly criticised. For example, Dryden (1631 - 1700) was vehement in his objections. Adler argues, ' about ... triple rimes the critics were apparently unanimous. Nobody liked them for serious non-dramatic compositions.' ${ }^{14}$ Ironically this is the period that some argue was the time in which use of the triplet flourished in the writing of poetry. ${ }^{15}$ While there is a 'scarcity of triplets' in the works of Alexander Pope (1688-

influence. Curial style in English at the time of Chaucer's death, argues Burnley, was perceived essentially as a technical style. Texts which depended upon a fully developed curial style in English can be found in legal documents from the early 1380s; English letters modelled on the style of the French appear towards the end of the century; and Chaucer in 1391 exploited the style in a technical manual. In more discursive literary prose, curial features occur not as a structural foundation but as an occasional connective convenience or a stylistic colouring, supported by other rhetorical devices of ordering. (p. 610)

${ }^{10}$ Burnley, (1986, p. 593).

${ }^{11}$ Although most interest in rhetoric focuses on Cicero, the most well-known triplet is credited to Julius Caesar who wrote back to the Senate on conquering the Gaul's, 'I came, I saw, I conquered.'

${ }^{12}$ Bornstein's research was published in 1977, Politzer's in 1961.

${ }^{13}$ Politzer, (1961, p. 484).

${ }^{14}$ Adler, (1961, p. 225).

${ }^{15}$ Balliet, (1965, p. 528) argues that the use of triplets in poetry, like some other literary forms, had an origin, a period of growth, a maturity, (of around 100 years) and then an end. The triplet, he argues, was an ...Footnote continued on next page...

Page 292 
$1744)^{16}$ Samuel Johnson $(1709-1784)$ was still using triplets throughout his prose in the mid- to late-1700s, something a number of his critics complained about. Archibald Campbell (c. $1726-1780$ ) in his booklet Lexiphanes (1774) attacked Johnson's style (with some success it should be noted) as 'consisting of a mass of polysyllables and triplets, mostly tautological.' Campbell accused Johnson of 'contaminating the English tongue; that his words were hard, his phraseology absurd, and his style affected. ${ }^{17}$ Robert Walpole $(1676-1745)$ described Johnson's use of the triplet as " triple tautology, or the fault of repeating the same sense in three different phrases." ${ }^{18}$

Nathan Drake (1766 - 1836, English essayist and physician) undertook an exhaustive analysis of Johnson's style and published his views in a number of contemporary periodicals. His arguments are at strong variance with most of Johnson's critics and he stated, 'Johnson first presented to the public those peculiarities and prominent beauties of style which immediately distinguished him, in so striking a manner, from all preceding writers and which have made so durable an impression upon our language. ... Johnson had no equal in harmony, propriety and energy. ${ }^{19}$ What is striking about Drake's analysis is that while he gives no opinion, as such, about the use of the triplet in Johnson's prose, in the hands of a master stylist the triplet is as effective as any

offspring of the pentameter couplet, but developed in its own way at its own rate. When the couplet was loose, open, and unpolished, there was little need for further variety, and poets wrote few triplets. When the couplet became tight, closed, and highly polished, as it did with Pope, the triplet was considered a violation of the rules. Interestingly, Balliet also argues that while the couplet owes it origins to French and Latin poetry, there is nothing in Latin equivalent to the triplet. The triplet (as used in poetry) is an English phenomenon whose history has not been written yet (at least not in 1965). If this is correct then the use of the triplets by Cicero would have been restricted to prose writing only.

${ }^{16}$ Adler, (1961, p. 226).

${ }^{17}$ Reynolds, (1935, p. 146).

${ }^{18}$ Reynolds, (1935, p. 151).

${ }^{19}$ Reynolds, (1935, p. 159). 
other device used by Johnson. The reason, Drake argues, is Johnson's attention to precision in his writing, with 'his long words, "abstract, and of classic derivation," formed on native analogies, and despite their heavy effect, they are so clear in their meaning, and so appropriate to their respective ideas that they express the author's meaning with complete accuracy. ${ }^{20}$

\subsubsection{Triplets - Clarity and Elaboration}

From this brief historical synopsis it is possible to better appreciate why rhetorical writers since ancient Greek and Roman times have chosen the triplet style. For some it is a way of being more precise. Politzer argues this is why the triplet style has its origins in legal documents that need to be as accurate as possible. He argues 'there is little doubt that the legal nature of these documents is responsible for much ... synonymic repetition. The desire to be exact leads to a style in which series of expressions ... are used extensively.' Furthermore, the increasing use of synonymic repetition (doublets and triplets) 'laid the foundation' as a stylistic device. The use of 'Romance' Latin words in conjunction with 'classical' Latin words was not only a stylistic device, but has also [been] useful [in] making phrase more generally comprehensible. ${ }^{21}$ Vos also argues, the desire for 'neatness' and accuracy explains why Roger Ascham favoured Cicero's use of the triplet style. ${ }^{22}$ Burnley in his examination of the curial prose style agrees that clarity and precision were desired objectives in legal documents. ${ }^{23}$

Burnley provides a further explanation for why triplets became popular. He examined the Rolls of Parliament from the fourteenth century and argues, 'in this period the history of the curial style illustrates a general tendency towards elaboration at the

\footnotetext{
${ }^{20}$ Reynolds, (1935, p. 159).

${ }^{21}$ Politzer, (1961, pp. 486-487).

${ }^{22}$ Vos, (1974, p. 364).

${ }^{23}$ Burnley, (1986, p. 596).
} 
expense of clarity. ${ }^{24}$ In making this argument it would be a mistake to think the one (elaboration) takes the place of the other (clarity). As studies of Cicero's style have shown, there was a careful and balanced concern for both objectives in using triplets. For example, in Orator, (p. 140) Cicero states that the ornate (ornatus) use of words is the aspiration of the perfect orator and 'springs from the writer's aspiration to the praise which is the reward of all perfect oratical art.' Furthermore, this ornate use of words can be created in one of two ways, 'through using single words, and through using words as they are arranged or joined together (Orator, p. 80),' ... and that 'units of threes are best. $^{, 25}$ In the development of his own style, Roger Ashcam adopted the view, "knowledge without eloquence is of no value. ${ }^{\prime 26}$ Balliet, in his examination of the use of the triplet, also found the triplet developed from a rather simple device 'to a complex poetic form within a form, that could add intensity, emphasis, and variety to the limited and sometimes monotonous pentameter couplet., ${ }^{27}$

A desire for clarity and elaboration are then important for a writer who uses triplets. It has already been argued Keynes used a variety of literary devices such as metaphors, analogies and allusion to clarify his economic arguments and it seems his frequent use of triplets was for the same reason. For example, when Keynes writes 'the Supreme Economic Council received almost hourly the reports of the misery, disorder, and decaying organisation of all Central and Eastern Europe,' he wants the reader to clearly grasp the magnitude of the problem, that is to say, while people are living in misery because of the destruction from the war, this misery is being added to because of the disorder among the countries of Europe and, furthermore the corruption at the heart of

\footnotetext{
${ }^{24}$ Burnley, (1986, p. 596).

${ }^{25}$ Vos, (1974, p. 349 and 362).

${ }^{26}$ Vos, (1974, p. 364).

${ }^{27}$ Balliet, (1965, p. 533).
} 
the governing and capitalist institutions not only has a decaying effect but piles more misery onto the peoples of Europe. ${ }^{28}$

In another example Keynes paints a picture of how the average Englishman, at least of his own class, 'regarded his state of affairs' before the war. The average Englishman in the late nineteenth and early twentieth century took for granted he lived in an era where goods of all variety could be easily sourced from any part of the globe and should he want to, 'could secure forthwith, if he wished it, cheap and comfortable means of transit to any country or climate without passport or other formality.' But most importantly, 'he regarded this state of affairs as normal, certain, and permanent, except in the direction of further improvement, and any deviation from it as aberrant, scandalous, and avoidable. ${ }^{29}$

In addition to using triplets for purposes of clarity Keynes also used triplets to elaborate on his arguments. Strachey was also fond of using triplets for clarity and elaboration. For example he uses three words to describe Cardinal Manning's demeanour on his appointment to Westminster: "kindness, gentleness, and conciliation." Strachey follows this up with a triplet of phrases: 'The new archbishop poured forth upon every side, all the tact, all the courtesy, all the dignified graces of a Christian magnanimity' and we have an example of how Strachey sought to elaborate on the description already given of Manning as kind, gentle, and conciliatory. ${ }^{30}$ There are numerous examples in Eminent Victorians of such uses of triplets and phrases linking triplets together, just as there is in Economic Consequences. For example, when Keynes describes Clemenceau at the Conference he uses a triplet of phrases: 'he closed his eyes often' and 'sat back in his chair with an impassive face of parchment,' with 'his grey gloved hands clasped in front of him.'

\footnotetext{
${ }^{28}$ Keynes, (1919, p. 5).

${ }^{29}$ Keynes, (1919, p. 10).

${ }^{30}$ Strachey, (1986, p. 80).
} 
This phrased elaboration follows a triplet of words to describe that Clemenceau's 'walk, his hand, and his voice' were vigorous. ${ }^{31}$ In describing Wilson's performance, Keynes again uses a triplet of phrases to elaborate his point that 'the President would be maneuvered off his ground,' and 'would miss the moment for digging his toes in,' then 'before he knew where he had been got to, it was too late. ${ }^{32}$

\subsubsection{Other Influences on Keynes' Prose Style}

In addition to this use of triplets for purposes of clarification and elaboration, Spurr's analysis of Strachey's style reveals a number of other ways in which he enhanced his prose style and we can assume that Strachey's influence on Keynes was such Spurr's findings have a strong correlation to Keynes. First, Strachey had a conscious desire to entertain, 'whether in biography or literary criticism, in the historical essay or private correspondence' and the idiosyncrasies' evident in Strachey's works [that] are a direct reflection of the man himself. ${ }^{33}$ Second, '[there was] the artistic resolution of the sexual contradiction that bedevilled Strachey. ${ }^{34}$ Spurr argues that Strachey's homosexuality did shape his literary style and in this he believes that Cyril Connolly's reflection, 'homosexuality is not a factor of importance in the assessment of a writer's style' is completely erroneous. However, Spurr argues, while Strachey's sexuality did make a difference to his literary style it did not do so in any "bold," "new," or "fresh" way we might expect from someone who had made claims to be a "rebellious immoralist." Rather, and this is Spurr's third fundamental argument, the individuality of Strachey's technique owes more to the adaption of 'Augustan and Victorian styles albeit for unconventional purposes, than to any stylistic innovation.' Others have also argued that what is striking

\footnotetext{
${ }^{31}$ Keynes, (1919, p. 27).

${ }^{32}$ Keynes, (1919, p. 40).

${ }^{33}$ Spurr, (1990, p. 32).

${ }^{34}$ Spurr, (1990, p. 32).
} 
about Strachey's and Keynes' stated rebelliousness and ideological opposition to Victorianism is, while they claimed to be "immoralists" they "advocated a version of male love that further emphasised class privilege, gender difference, and male superiority. ${ }^{\prime 35}$ While Strachey and Keynes thought of themselves as liberals and rebels, in practice they struggled to break free from the mores and conventions of their Victorian forebears and their own upbringing. While they repudiated entirely customary 'morals, conventions and traditional wisdom,' they were concerned about being found out by a society whose values reached back to the early 1800's and the ascension of "Victorianism."

One of the best indicators for claiming Strachey's style owed more to his Victorian past than his modernist present was the special 'aesthetic affinity [Strachey had] with the writings of Edward Gibbon $(1737-1794) .{ }^{36}$ Strachey continually placed primacy on the importance of historical and biographical prose writers of the past in the development of his own literary skills. Foremost amongst these are the combination of Strachey's control over his material and the influence of his personality since 'one seeks the discipline of art, the other enlivens communication of information and deference to the conventions of prose composition with the intimacy of individuality. ${ }^{37}$ As Strachey grew older and matured he strove to develop his own unique style, even attempting to break free of these historical influences, with an idiosyncratic prose, which would win the attention he always craved and elicit support for the principles he espoused. Spurr argues:

Yet the individuality of Strachey's technique owes as much to the adaption of conventional styles, Augustan and Victorian, to his unconventional purposes as to innovation. Favouring a Latinate vocabulary and an elegant cadence, exploiting the intricacies of etymology and observing the disciplines of order and balance,

\footnotetext{
${ }^{35}$ Taddeo, (1997, p. 198).

${ }^{36}$ Spurr, (1990, p. 32).

${ }^{37}$ Spurr, (1995, p. 79).
} 
Strachey expresses an aesthetic affinity with Augustan procedures and especially the writings of Edward Gibbon. ${ }^{38}$

Strachey had begun reading Gibbon at school and for literary inspiration was to return to The Decline and Fall of the Roman Empire many more times in the years ahead. So taken was Strachey on the first reading of Gibbon that he composed a parody of Gibbonian rhetoric called "The Decline and Fall of Little Red Riding Hood," written in 1896. Strachey's desire to entertain had begun early, something that studying Gibbon allowed him greater ability to do by imitating a style he found amusing. In preparing himself for the Christ Church scholarship to enable the furthering of his studies at University he chose as his special subject the Early Roman Empire. He wrote to his mother at this time, 'I have been reading the Great Gibbon lately and have just finished the two chapters on Christianity. They are the height of amusement - his attitude throughout so unimpeachably decorous.' When writing Eminent Victorians Strachey would read aloud sections from Gibbon to Carrington. ${ }^{39}$ In 1929 he wrote to Roger Stenhouse (his lover at the time), 'I've now relapsed into my beautiful new Gibbon' (September 9 1929) and four days later, 'My laziness is becoming more scandalous than ever. I do nothing but read Gibbon - first in the quarto - then in Bury's edition,' (13 September 1929).

As with Eminent Victorians and Economic Consequences Gibbon's magnum opus was a publishing success and remains in print some two hundred years after its initial publication. Craddock argues, while this continuing interest is due to the work's narrative style, its world-view and implicit commentary on its own age, the success of The Decline and Fall is due to the demands Gibbon placed on treating history in a fresh way, a direct result of the influence of the fifteenth century Renaissance. ${ }^{40}$ When applying research

\footnotetext{
${ }^{38}$ Spurr, (1995, p. 119).

${ }^{39}$ Holroyd, (1995, p. 397).

${ }^{40}$ Craddock, (1988, p. 570).
} 
techniques, using general rules for testing evidence, and taking care with annotations, Gibbon followed the Renaissance authors in treating history as a craft rather than an art. On the care Gibbon exercised Craddock comments:

Unlike some of his contemporaries Gibbon identified the source(s) of every statement he presented as a datum rather than a conclusion or interpretation, and he qualified, developed, or provided complex contexts for many of his textual statements in his notes. Even when the notes were banished to the end of the volume, literally hundreds of note numbers warned the reader that the apparent self-sufficiency of the text was only temporary. ${ }^{41}$

For Keynes as with all historians since Gibbon, attention to craft is clear. For example, Keynes carefully keeps a record of the many sources and supporting information by way of notes in Economic Consequences.

Of just as much interest to Strachey and Keynes as Gibbon's craft, was the 'Gibbonian method,' which means narrative is not merely data and abstractions, but people and events. These events, however, are not 'isolated, inexplicable, random, hypothetical, or invented; they are mutually determined, related to psychological and political patterns, and subject to our moral and intellectual evaluation. ${ }^{42}$ Furthermore, Gibbon acted on his own belief the historian must be detailed, accurate, balanced, conscious of psychological probability, and desirous of discovering reliable and widespread patterns among historical occurrences, 'for the benefit of his own and future ages. $^{\prime 43}$ Finally, we can see the lasting influence of Gibbon on Strachey and Keynes from Gibbon's contribution to the writing of history in a 'modern' way. Gibbon was among the first 'historical' writers to realise it is impossible to write objective history. When Walter

\footnotetext{
${ }^{41}$ Craddock, (1988, p. 571).

${ }^{42}$ Craddock, (1988, p. 577).

${ }^{43}$ Craddock, (1988, p. 586).
} 
Bagehot quipped that Gibbon 'did not know the difference between himself and the Roman Empire,' it was the recognition that Gibbon knew all too well that honest historians cannot write themselves out of their histories. ${ }^{44}$ For Gibbon 'it was the very intervention in the selection and ordering of their material, their subtle splitting of the 'splendid and brittle mass ${ }^{\prime 45}$ of their sources, and, above all, their very participation in the construction of a 'candid and rational inquiry, ${ }^{46}$ which makes the past alive and - most importantly for their readers - inescapably part of the present. ${ }^{47}$ Similarly both Strachey and Keynes brought alive the characters they wrote about because they wrote as if they were often participants in the scenes they described.

There were of course influences other than Gibbon that affected Strachey's and Keynes' styles. These included such nineteenth-century sages as Carlyle and Arnold who were more important than the artistic literary experimentations practiced by others of the Bloomsbury Group and the Modernists. So, while Strachey and Keynes believed they belonged to a generation that renounced 'religion and politics, proclaimed the death of God, and declared that "love is the only reality," in practice they struggled to break free from the mores and conventions of their upbringing. ${ }^{48}$ For example, when Strachey wrote of Cardinal Manning's doubts: Where was he? Manning asked himself. What had he accomplished? Had any of it been worthwhile? Strachey imposed his own rebellion against religion and God into the mouth of Manning. In similar vein Keynes sought to impose his own dislike of politics onto the minds of his readers by demeaning the politicians themselves. For example, when he describes Clemenceau as only having

\footnotetext{
${ }^{44}$ Bagehot, (1858, p. 104).

${ }^{45}$ Bagehot, (1858, p. 736).

${ }^{46}$ Bagehot, (1858, p. 446).

${ }^{47}$ Kelly, (1997, p. 54).

${ }^{48}$ Taddeo, (1997, p. 198).
} 
France's interests in mind, he describes Clemenceau, as already discussed, as feeling about France as Pericles felt of Athens - 'unique value in her, nothing else mattered; but his theory of politics was Bismarck's. He had one illusion - France; and one disillusion mankind. ${ }^{49}$ Statements such as this shocked many of Keynes' readers. Where was the verifiable evidence that Clemenceau disliked mankind more than he liked France, and France more than the French themselves? This style of prose provided Keynes' critics with the ammunition they wanted. Did this not prove what they were saying of Keynes, that he was pro-German and vindictive as well?

\section{It has been argued Keynes' reaction to critics of Economic Consequences was to} accuse them of misrepresenting his intentions. But, what really annoyed his critics was the prose style he chose to use, as Strachey had done before him, albeit it is a conservative prose style but one that both sought to be ironical and 'delectably humorous' at the same time ${ }^{50}$ For example, when Strachey wrote of Florence Nightingale that 'her conception of God was certainly not orthodox. She felt towards Him as she might have felt towards a glorified sanitary engineer; and in some of her speculations she seems hardly to distinguish between the Deity and the Drains,' Strachey provided his friends and admirers with something to laugh about. ${ }^{51}$ After all, in an age where "cleanliness was close to godliness" such a witty turn of phrase no doubt was one of those 'delectably humorous' lines that caused Bertrand Russell to laugh out loud when he first read Eminent Victorians in Brixton Goal. ${ }^{52}$ But, it equally played into the hands of Strachey's critics, such as the

${ }^{49}$ Keynes, (1919, p. 29).

${ }^{50}$ Spurr, (1995, p. 33).

${ }^{51}$ Strachey, (1986, p. 158).

52 Ottoline Morrell had written to Strachey to tell him how much Russell had enjoyed the book, despite her own feelings of offence at Strachey's satire of religion. Strachey wrote back to Morrell on $26^{\text {th }}$ May 1918 to 'say that I think it a great honour that my book should have made the author of Principia Mathematica laugh out loud in Brixton Goal.' (Strachey to Morrell, letters held in the Humanities Research Center, University of Texas at Austin. Refer Levy, (2005, p. 397). 
Master of Balliol who has pilloried Strachey as 'that contemptible sniggerer' ${ }^{53}$ and the reviewer of The Daily Telegraph who says of Strachey's most famous work, it consists of nothing more than 'sniggering little hatchet jobs. ${ }^{\text {,54 }}$

While Keynes did not fully replicate the deliberately humorous manner of writing Strachey so enjoyed, he nonetheless used language in ways that mirrored Strachey's irreverence and often met with similar hostility to that received by Strachey. For example, when Keynes used references to Wilson as, 'his temperament was not primarily that of the student or the scholar,' ${ }^{55}$ 'the poor President would be playing blind man's buff in that party, ${ }^{56}$ 'this blind and deaf Don Quixote, ${ }^{57}$ 'he was by no means a businessman, ${ }^{58}$ 'the President was like a Nonconformist minister, perhaps a Presbyterian,' ${ }^{59}$ 'his temperament was essentially theological and not intellectual, ${ }^{60}$ and 'the President's dullness, ${ }^{61}$ Keynes was surprised at the reaction he received and remained insensitive to the deep offence he caused by using graphic descriptions of the then serving US head of state. Moggridge in Collected Works summarises:

Keynes marvelled at the bitterness of the American press. ... he had handed the opponents of the President Wilson some red-hot political ammunition. Although he had written a longer version of the preface

\footnotetext{
${ }^{53}$ Kenny, (1986, p. 15).

${ }^{54}$ Chamberlain, E. R., 2 June 1982, “Eminently A. L. Rowse," The Daily Telegraph, p. 15.

${ }^{55}$ Keynes, (1919, p. 37).

56 Keynes, (1919, pp. 37-38).

57 Keynes, (1919, p. 38).

58 Keynes, (1919, p. 38).

59 Keynes, (1919, p. 38).

60 Keynes, (1919, p. 38).

61 Keynes, (1919, p. 41).
} 
for Economic Consequences in November 1919, which contained a second paragraph acknowledging the mitigating circumstances of the President's illness and emphasizing his basic sincerity he had not made use of it. ${ }^{62}$

The French never forgave Keynes his portrayal of Clemenceau nor what they perceived as his pro-German and anti-French sentiments. ${ }^{63}$

Keynes' astonishment at some of the reactions to his book may have, to a degree, been justified as others clearly felt similarly as he did about the leaders at Versailles. For example, Nicolson, who attended Versailles wrote:

That spiritual arrogance which seems inseparable from the harder forms of religion had eaten deep into his [Wilson's] soul. It had been confirmed in the course of many battles with the Faculty of Princeton. His vision had been narrowed by the intensive ethical nurture which he had received: he possessed, as he himself admitted, 'a one-track mind.' This intellectual disability rendered him blindly impervious, not merely to human character, but also shades of difference. He possessed no gift for differentiation, no capacity for adjustment to circumstances. It was his spiritual and mental rigidity which proved his undoing. It rendered him as incapable of withstanding criticism as of absorbing advice. It rendered him blind to all realities which did not accord with his pre-conceived theory, even to the realities of his own decisions. $^{64}$

Hansen, who attended the Conference as a journalist wrote of Wilson:

President Wilson is the great tragic figure of the Peace Conference. ... he demonstrated anew that the fortunes of people in the mass are affected by the limitations of the individuals who lead them. ...

\footnotetext{
${ }^{62}$ Keynes, (CW XVII, p. 42).

63 Keynes, (CW XVII, pp. 164-165).

${ }^{64}$ Nicolson, (1945, p. 163).
} 
Woodrow Wilson had tenacity, but also stubbornness; vision, but also myopia; a sense of personal responsibility for the general welfare and a deviant conviction that his judgment was accurate. This made him the architect of the League of Nations; this in turn lost him his American support, and the peace. ${ }^{65}$

\subsubsection{Innovation and Style in Keynes' and Strachey's Prose}

It has been argued both Strachey and Keynes' literary style owed a great deal to their conventional pasts. However, it would be a mistake to see either man's style as somehow "outdated" or divorced from more popular modernist styles. After all, both Eminent Victorians and Economic Consequences were significant publishing successes in the modernist era and both attracted a diversity of critical comment, much of which continues to the present day. Spurr argues, the answers to this literary success can be found in individual and 'subtle transformation of conventional procedures.' In other words, while both Strachey and Keynes drew inspiration from their literary forebears they nonetheless provided an entirely individual and new "pitch." Commenting on Strachey Spurr argues that in his writing he seemed to

vocalise the many contradictions of his mind and sensibility; its passion and detachment, humour and sadness, cynicism and hope, solitariness and desire for love. Introducing the vocabulary and cadence of Mandarin ${ }^{66}$, Strachey proceeds subtly and wittily to pervert and violate its conventions, manipulating the solemnity of the Ciceronian, Gibbonian dialect ... it is as much in the manner of

\footnotetext{
${ }^{65}$ Hansen, (1949, p. 27).

${ }^{66}$ Skabarnicki, Anne, "Strachey, Lytton British, 1880-1932," http://www.custom-essay.net/essayencyclopedia/Lytton-Strachey-Essay.htm explains the full term "Camp Mandarin" as an idiom Spurr first dubs as a witty parody of an elite mode, used to undermine the conventional views of the mandarins through incongruity and exaggeration. Mandarins were members of an elite group and were high-ranking officials in the ancient Chinese Empire with extensive powers and high status in intellectual and cultural circles.
} 
Strachey's prose as in its matter that we discern the fascinating and complex personality behind it. ${ }^{67}$

A good example of this "new" and individual twist on conventional literary style is Strachey's elaboration and exaggeration. Spurr argues, Strachey's persistent use of the style would render his work predictable and tedious but in the hands of someone as accomplished as Strachey the style is successfully subjected to a series of variations. ${ }^{68}$ Similarly, as has been highlighted, when critics of Samuel Johnson condemned his persistent use of triplets others were quick to jump to Johnson's defence. What might have seemed tedious in other writers was transformed in the hands of a craftsman. In one example Strachey vents his anger at the political injustice of the abuses of the French judicial system in the eighteenth century - 'the scandal of arbitrary imprisonment, the futile barbarism of torture, the medieval abominations of the penal code. ${ }^{69}$ Or in his treatment of Creighton, Strachey says, 'he believed in the Real Presence. He was opposed to Home Rule. He read with grave attention the novels of Mrs. Humphrey Ward. ${ }^{70} \mathrm{By}$ descending from humour into pathos Strachey summarises Creighton's denominational

${ }^{67}$ Spurr, (1995, pp. 31-32).

${ }^{68}$ Spurr, (1995, p. 36).

${ }^{69}$ Strachey, (1948, p. 96).

${ }^{70}$ Strachey, (1980, p. 114).

Mary Augusta Ward (1851-1920) wrote under the pseudonym of Mrs. Humphrey Ward. Her uncle was the poet Matthew Arnold and her grandfather was Thomas Arnold, the famous headmaster of Rugby School. As a young woman she married Humphrey Thomas Ward, a writer and editor. She began her career writing articles for magazines while working on a book for children that was published under the title Milly and Olly. She wrote a number of novels, which contained strong religious subjects matter relevant to Victorian values she herself practiced. Her novels enjoyed publishing success in both Great Britain and the United States. In 1903 the New York Times rated her Lady Rose's Daughter the bestselling novel in the United States. Source: Sutherland, (ODNB, 2004, 36736). 
allegiance: the nonsense of its theology, the scourge of its erastianism and the Victorianism of its morality 'to subordinate demerits in the course of celebration. ${ }^{71}$

This "flourish" Strachey used to describe his subjects can be mapped closely to Keynes' own "elaboration of phraseology" as he expressed his frustration with the politicians whom he blamed for the Carthaginian Peace. In comparing Wilson's performance to Lloyd George he asks the reader, 'What chance could such a man have against Mr. Lloyd George's unerring, almost medium-like, sensibility to every one immediately around him?' Having asked the question Keynes uses triplets to answer his own question. The British Prime Minister, states Keynes, possesses 'six or seven senses not available to ordinary men ... judging character, motive, and subconscious impulse.' On the one hand Keynes exaggerates Lloyd George's senses beyond the normal to six or seven, making them unique to Lloyd George, which allowed him to anticipate what Wilson was going to say next and in turn allowed Lloyd George to frame his appeal or argument 'best suited to the vanity, weakness, or self-interest of his immediate auditor.' This meant the "poor" President would be playing 'blind man's buff in that party.' Just as Strachey moved from words, to phrases, and on to sentences in triplets, so did Keynes. From the sentences and phrases used above Keynes rounds out his discussion with a triplet of sentences:

Never could a man have stepped into the parlour a more perfect and predestined victim to the finished accomplishment of the Prime Minister. The Old World was tough in wickedness anyhow; the Old World's heart of stone might blunt the sharpest blade of the bravest knight-errant. But this blind and deaf Don Quixote was entering a cavern where the swift and glittering blade was in the hands of the adversary. $^{72}$

\footnotetext{
${ }^{71}$ Spurr, (1995, p. 37).

72 Keynes, (1919, pp. 37-38). In his description of Wilson Keynes uses with skill and variety triplets to enhance his rhetoric. In the very next paragraph following this one, for example, Keynes explores what sort ...Footnote continued on next page...
} 
Spurr argues, for both Strachey and Keynes, the use of triplets to highlight political and "polemical" injustices is just as effectively used 'in the bathos of deflation.' An example of using triplets anti-climatically can be found in Strachey's summary and dismissal of Addison - 'that charming, polished, empty personality. ${ }^{73}$ The third epithet laughs at the reader who might have supposed that charm and polish were tending to praise. Another example is Strachey's view of the 'holiness of the Middle Ages ... which embodied itself in prayer, asceticism, and dirt. ${ }^{74}$ Keynes also drew on bathos, when, for example he says of Wilson 'his head and features were finely cut and exactly like his photographs, and the muscles of his neck and the carriage of his head were distinguished. But, like Odysseus, the President looked wiser when he was seated. ${ }^{75}$

The use of such words and phrases were intended by Strachey and Keynes to harness the humour from a situation, although Keynes never took it to the extremes Strachey so enjoyed doing. Commenting on Strachey's use of humour Spurr argues, 'ranging from sarcasm and facetiousness, where laughter is cheaply bought, to the elegance of the epigram, Strachey's manner is a compact comic medium. ${ }^{76}$ Epigrammatic succinctness and resonance satisfied Strachey intellectually, aesthetically and emotionally. This was the perfect verbal medium for Strachey's desire to justify his separation from a hostile world that had decreed that he was immoral, illegal and dangerous to know, views

of person Wilson really was and suggests on the one hand that he was 'a man of force, personality and importance' and in arguing that Wilson's temperament was theological rather than intellectual qualifies his view with the words 'with all the strength and the weakness of that manner of thought, feeling, and expression.'

${ }^{73}$ Strachey, (1933, p. 17).

${ }^{74}$ Strachey, (1933, p. 123).

${ }^{75}$ Keynes, (1919, p. 37).

${ }^{76}$ Spurr, (1995, p. 38). 
that both Strachey and Keynes shared in their most intimate of documented exchanges. ${ }^{77}$ Their own personal sufferings, both considered themselves unattractive, and, at times, bitterness, find expression in their epigrammatic humour, a tradition that, some scholars argue, belongs to 'high camp.' 78 Examples of exaggerated 'camp' language are not difficult to find in Strachey's works although less so in Keynes' writings. Strachey in "Two Frenchmen" quips; 'the greatest misfortune that can happen to a witty man is to be born

${ }^{77}$ Some examples include:

1. Strachey to Keynes, "One plants one's penis in so many peculiar spots! - at least, I do! And really, it's not much good you pretending, at this time of day, that you don't too." Strachey to Keynes, 1 July, 1907, Lancaster Gate, King's College Archives, JMK/PP/45/316/3/81

2. Strachey to Keynes: "I had a very pleasant evening at Fitzroy Square on Thursday, and, as usual, all but buggered Clive. He was divine - a soft shirt and hair and complexion that lifted me and my penis to the heights of heaven. Oh! Oh! Oh!" Strachey to Keynes, 21 October, 1907, Belsize Gardens, King's College Archives, JMK/PP/45/316/3/149.

3. Keynes to Strachey: "To-night I dined for the second time at their High Talk. The food is excellent, but, my God, one feels a don. I play the part admirably, perhaps it belongs to me, but I should like to rape an undergraduate in the Confirmation Room, just to make them see things a little more in their true light. Not that rape of an undergraduate is very typical of real life, alas." Keynes to Strachey, 21 March, 1909, 6 Harvey Road, Cambridge, King's College Archives, JMK/PP/45/136/4/136.

4. Strachey to Keynes: "I have also been examining some antique family letters - temp. Warren Hastings. During one of the risings letters were carried in quills, rolled up very small. This was known - I've now discovered that the quills were put up the black's arses who carried them. The letters were called 'fundamental chits' and they usually arrived, my grandfather observes, "safe, but not sweet." Do I have to put this culturally piece of information into my great work? Would it shock the ladies?" Strachey to Keynes, 7 July, 1910, Belsize Gardens, King's College Archives, JMK/PP/45/316/4/163.

5. Keynes to Strachey: "May God blight and blast you! May your penis become an asparagus and your balls an artichoke!" Keynes to Strachey, 11 March, 1906, King's College, King's College Archives, JMK/PP/45/316/2/155.

${ }^{78}$ In one letter from Keynes to Strachey he wrote, "My dear, I have always suffered. I suppose I always will from a most detestable obsession that I am so physically repulsive that I've no business to launch my body onto someone else's." Keynes to Strachey, 11 March, 1906, King's College, King's College Archives, JMK/PP/45/316/2/155. 
out of France. ${ }^{79}$ In his opening to Eminent Victorians he also quips, 'the history of the Victorian Age will never be written; we know too much about it. For ignorance is the first requisite of the historian, ${ }^{80}$ Spurr argues, in these two examples we are bowled over by the audacity of the statements and we must continue reading in order to discover whether the observations are true because 'the method is as captivating as the message. ${ }^{, 81}$ When we examine Keynes' writing we find the same epigrammatic humour that wills the reader to determine if the statement is as preposterous as it seems. For example, when comparing Lloyd George's and Wilson's intellects, Keynes states: 'Never could a man have stepped into the parlour a more perfect and predestined victim to the finished accomplishments of the Prime Minister; ${ }^{\prime 82}$ On the Fourteen Points that had been blatantly manipulated in the framing of the final Treaty; 'he [Wilson] could have preached a sermon on any one of them or have addressed a stately prayer to the Almighty for their fulfilment; but he could not frame their concrete application to the actual state of Europe. $^{83}$

In contrast to the originality of the epigrams Strachey and Keynes used, there is, in places, the recourse to deliberate cliché and colloquialism. Clichés such as 'Albert was in the habit of playing second fiddle, ${ }^{84}$ (to his wife Queen Victoria) and 'Voltaire kept the ball rolling,' (in his correspondence with Frederick the Great) ${ }^{85}$ are used by Strachey for amusement. In Eminent Victorians he describes the Church of England, prior to the Oxford

\footnotetext{
${ }^{79}$ Strachey, (1933, p. 71).

${ }^{80}$ Strachey, (1986, p. 17).

${ }^{81}$ Spurr, (1995, p. 39).

${ }^{82}$ Keynes, (1919, p. 38).

${ }^{83}$ Keynes, (1919, p. 39).

${ }^{84}$ Strachey, (1921, p. 97).

${ }^{85}$ Strachey, (1980, p. 55).
} 
Movement, as having slept 'the sleep of the ... comfortable,' the inference being that to all intents and purposes, the church was dead. ${ }^{86}$ Similarly we find Keynes used deliberate clichés such as, 'on this sandy and false foundation,' to describe the economic state of Europe prior to and immediately following World War One. ${ }^{87}$ He described the "Devil" of Malthusian population growth outstripping the world's ability to feed it as 'for the next half century he was chained up and out of sight,' but as a result of the conflict that had engulfed Europe 'now perhaps we have loosed him again. ${ }^{88}$ And in describing the tensions that had come upon Europe prior to the war, the rivalries, militarism and imperialism 'were to play the serpent to this paradise. ${ }^{89}$

\subsubsection{The Influence of Keynes' and Strachey's Sexuality}

What is striking about the elaborative styles of both men's writing are the explicit ways in which they described their subjects. Yet this is in contrast to the indirect way both men promoted some of their radical views on religion and sexuality. Some commentators attribute this contradiction to both men's homosexuality. Strachey and Keynes lived under the shadow of the 1885 Criminal Law Amendment Act that criminalised homosexuality. The "depressing" memory of Oscar Wilde's trial and rumours of ruined reputations of public school masters haunted their daily lives. Yet both men avoided the company of those whose reputations were dubious. In a letter to Keynes, Strachey described one such incident involving a homosexual: 'I was dreadfully afraid of his clinging to us (after your

accounts) and I fear I may have been rude. ${ }^{90}$ Keynes reminded Strachey 'how damned

\footnotetext{
${ }^{86}$ Strachey, (1986, p. 30).

${ }^{87}$ Keynes, (1919, p. 1).

${ }^{88}$ Keynes, (1919, p. 8).

${ }^{89}$ Keynes, (1919, p. 10).

${ }^{90}$ Strachey to Keynes, ?, 1908, King's College Archives, JMK/PP/45/316/4.
} 
careful one has to be ... in this respect one is so hopelessly in the hands of others. ${ }^{91}$ Spurr argues there is a direct link between Strachey's repressed sexuality and his literary style. It is, he argues, 'distinctive, an indirect technique that is polished and authoritative, in the style of the confident avatars of orthodoxy, but it is animated by a world view and directed to conclusions that are markedly heterodox. ${ }^{92}$ It humorously exaggerates the orthodox while pursuing the artificial and the theatricalisation of experience. Sontag identifies these as essential components of the homosexual sensibility and argues, 'in his prose style, Strachey reveals his convoluted sexuality, though cautiously and covertly achieving a consummation in art which life so frustratingly denied him. ${ }^{93}$

Those who have examined the links between sexuality and literary style sometimes argue the writings of Strachey belong to a literary history of homosexuality, 'a story of indirection, subterfuge, disguise or outright suppression. ${ }^{94}$ Jeffry Meyers identifies 'cautious and covert qualities' in the prose of several authors of Strachey's generation. ${ }^{95}$ Context is important because, as Meyers also argues, the emancipation of the homosexual has led paradoxically to the decline of his art. ${ }^{96}$ Spurr argues this is an indisputable reality and homosexual oppression, whatever its other effects, has been productive of literary artistry of a high order in the works of Proust, Forster and others. Today, following the post-war, post-Kinsey sexual revolution, the "Stracheyian procedure" is deemed unnecessary, even reprehensible. The contemporary homosexual author is expected to be direct and "unblushingly pornographic." Spurr believes 'this gain in frankness ... is at the

\footnotetext{
${ }^{91}$ Keynes to Strachey, 10 April, 1907, King's College Archives, JMK/PP/45/316/3.

${ }^{92}$ Spurr, (1995, p. 34).

${ }^{93}$ Spurr, (1995, p. 35).

${ }^{94}$ Adams, (1970, p. 7).

${ }^{95}$ Meyers, (1987).

${ }^{96}$ Adams, (1970).
} 
expense of art. $^{, 97}$ When comparing Economic Consequences to Eminent Victorians there is not the same intentional camp humour in Economic Consequences but the similarities are not difficult to find.

\subsubsection{Summary - Lytton Strachey's Eminent Victorians}

A comparison of Eminent Victorians and Economic Consequences suggests Strachey's style had a significant influence on Keynes' writing style. The first important clue to this influence is the way in which both men used triplets. Despite triplets falling in and out of favour with writers, both men liked the ways in which they could describe their characters with greater clarity in addition to being more elaborative with language. They found it even better when beginning with word triplets and could move onto phrases of triplets and finally conclude with a triplet of sentences.

Another way in which we see influence at work is the way both men enjoyed shocking their readers, Strachey more overtly but both took pleasure in the effect it had. After all both men considered themselves "rebellious immoralists," although as highlighted this view of themselves was, in practice somewhat restrained. Some believe this is best explained by their suppressed homosexuality at a time when it was a crime to be homosexual. But, taken together both men ultimately gave the world new and unique forms of literary expression that differed from their parent's generation.

However, it is not surprising more conventional influences were also at work. In one endearing example from Keynes' personal papers he had sent his mother a draft of one of the early manuscript copies of Economic Consequences to which his mother wrote back:

My Darling Son, I have made many marks on these first 50 pages many of them small points, but some in the interest of cleanliness of

\footnotetext{
${ }^{97}$ Spurr, (1995, p. 123).
} 
expression, and some as matters of discretion. It would be unfortunate to subject yourself to criticism for expressions which do not affect the argument, and that might put you out of court with some people. The points to which I want specially to call your attention are the following - probably you have already modified the most important.

p. 4. - omit the "showman" section

p. 38 - top paragraph as at present, it seems to me to give unnecessary offence to both Wilson and Lloyd George - and mixes up blind man's buff, the spider, the fly, and Don Quixote p. 41 - I don't like calling the President ignorant even if he is! p. 46 - The Artful Dodger has doubtless disappeared. We couldn't keep him in.

p. 47 - I don't like orgy - it is not a nice word and anyhow you can't clothe yourself in it.

p. 50 - last sentence but one. It isn't needed and spoils the effect - do make away with it."

In the next manuscript draft Keynes had made every change suggested by his Mother! ${ }^{98}$

${ }^{98}$ ECP Correspondence Archives, Undated, King's College Archives, JMK/EC/1/2. 


\subsection{Virginia Woolf and Psychological Realism}

Keynes' and Strachey's friendship was forged at Cambridge when both were undergraduates and de facto leaders of the Apostles. Both followed the other's writing careers with interest, regularly asking the other to review drafts of texts they were working on. Their subsequent involvement with Bloomsbury meant further and different influences on their writing styles, especially from their association with Virginia Woolf. Apart from the acknowledged influence Bloomsbury had on early twentieth-century intellectual life in Britain, Strachey, Keynes, and Woolf were responsible for fundamentally changing the way their own genres of literature are viewed. Strachey pioneered a new way of writing biography, Keynes set in train a new way of dealing with economics, and Woolf changed the way in which novels were written. Apart from the publishing success they each enjoyed they all introduced into their characters a new sense of psychological realism.

Before publication of Eminent Victorians Virginia Woolf had published her first novel, The Voyage Out (1915) and by the time Economic Consequences had appeared she had also written and published Night and Day (1919). In The Voyage Out the main character Rachel Vinrace embarks for South America on her father's ship and is launched on a voyage of self-discovery. The mismatched group of passengers provided Woolf with an opportunity to satirise Edwardian life. She also introduced Clarissa Dalloway who became the central character in her later, and best-selling novel, Mrs. Dalloway (1925). In Night and Day Woolf contrasts the daily lives of Katherine Hilbery and Mary Datchet and examines the relationship between love, marriage, happiness and success.

Researchers often comment on how Woolf develops the inner psychology and complex personalities of her characters in ways not previously attempted by novelists. Most see this treatment as a reflection of the time period when psychology was an emerging discipline. Johnson argues that Woolf in her works reflected this modernist trend: 
Virginia Woolf was the most adamant of the modernists in her claim that "we are sharply cut off from our predecessors." (Essays III, 357) However, she also believed in the continuity of culture, and in the writers' role as "receptacle" of cultural currents. ${ }^{99}$

Rosenbaum claims Woolf's 'writing was shaped by a series of intellectual assumptions about reality, perception, morality, government, and art. $^{\prime 100}$ However, he says little about human psychology, which Johnson argues needs to be included because it was an important intellectual element in her writing. ${ }^{101}$ He argues Woolf was influenced by the psychologists' working hypotheses about personality, 'and her extraordinary sensitive antennae picked up psychological ideas in the air. ${ }^{102}$ In a draft paper of "Character in Fiction" (1924) given before the Cambridge Heretics Society she wrote:

No generation since the world began has known quite so much about character as our generation ... the average man or woman today thinks more about character than his or her grandparents; character interests them more; they get closer, they dive deeper in to the real emotions and motives of their fellow creatures. There are scientific reasons why this should be so. If you read Freud you know in ten minutes some facts - or at least some possibilities - which our parents could not have guessed for themselves ... There is a ... vaguer force at work - a force which is sometimes called the Spirit of the Age or the Tendency of the Age. This mysterious power is taking us by the hand, I think, and making us look much more closely into the reasons why people do and say and think things. (Essays III, 504). ${ }^{103}$

\footnotetext{
99 Johnson, (1994, p. 139).

${ }^{100}$ Rosenbaum, (1983, p. 11).

101 Johnson, (1994, p. 139).

102 Johnson, (1994, p. 139).

103 Johnson, (1994, p. 140).
} 
It has been noted that Woolf had a problematic attitude with Freud and she only read anything of substance from Freud after the outbreak of World War Two. ${ }^{104}$ However, despite her own claim that she knew psychoanalysis 'only in the way of ordinary conversation' (December 7, 1931) this, argues Johnson, represents a severe understatement on Woolf's part. The conversations she had about psychoanalysis were 'far from ordinary' since they took place with those who were at the forefront of the psychoanalytic movement in Britain. ${ }^{105}$ Furthermore, she was raised in an environment in which current psychological, as well as philosophical ideas were regularly discussed. The earliest influence was Cambridge thought and according to Johnson:

[Moore's presence at Cambridge] has obscured other Cambridge influences on Bloomsbury. When it was realised that Moore's teachers included the most distinguished psychical researcher of the day, Henry Sidgwick; an idealist, John McTaggart; and two of the most eminent English psychologists of the day, G. F. Stout and James Ward, one cannot help wondering to what degree the currents of thought expounded by them permeated the Cambridge atmosphere.

Woolf certainly felt the impact to varying degrees of all these thinkers, mainly second-hand, through the friends and relations who attended Cambridge and with whom she held numerous discussions as a member of the Bloomsbury group. ${ }^{106}$

Her own husband Leonard also took a strong interest in Freud from an early stage and James Strachey, brother of Lytton, both of who were in turn influenced by Henry Sidgwick, Past President of the Society of Psychical Research, had read works by Freud as early as

\footnotetext{
${ }^{104}$ Lee, (1997, p. 722).

105 Johnson, (1994, p. 140).

${ }^{106}$ Johnson, (1994, p. 145).
} 
1904. ${ }^{107}$ By 1924 Freud had a high profile as a psychoanalyst, and his ideas were discussed regularly by the Bloomsbury group. ${ }^{108}$

An examination of a selected group of character sketches from Keynes, Strachey and Woolf show how these influences in the form of psychological realism influenced how they developed their characters. While these are small examples, they are not isolated as all three writers demonstrate an interest in the psychological motives of their characters rather than providing mere descriptions of them and their actions.

${ }^{107}$ Soon after James married Alix in 1920 they moved to Vienna, where James, an admirer of Freud, began psychoanalysis with the great man. Freud asked the couple to translate some of his works into English, and this became their lives' work. Both became psychoanalysts themselves, and as well as Freud's works they also translated works by a number of other European psychoanalysts. Their translation of Freud's works, in twenty-four volumes, remains the standard edition of Freud's works to this day.

108 Johnson, (1994, p. 140). 
Table 23: Extracts from the writing of Virginia Woolf, Lytton Strachey, and Maynard Keynes from a Psychological Realism perspective.

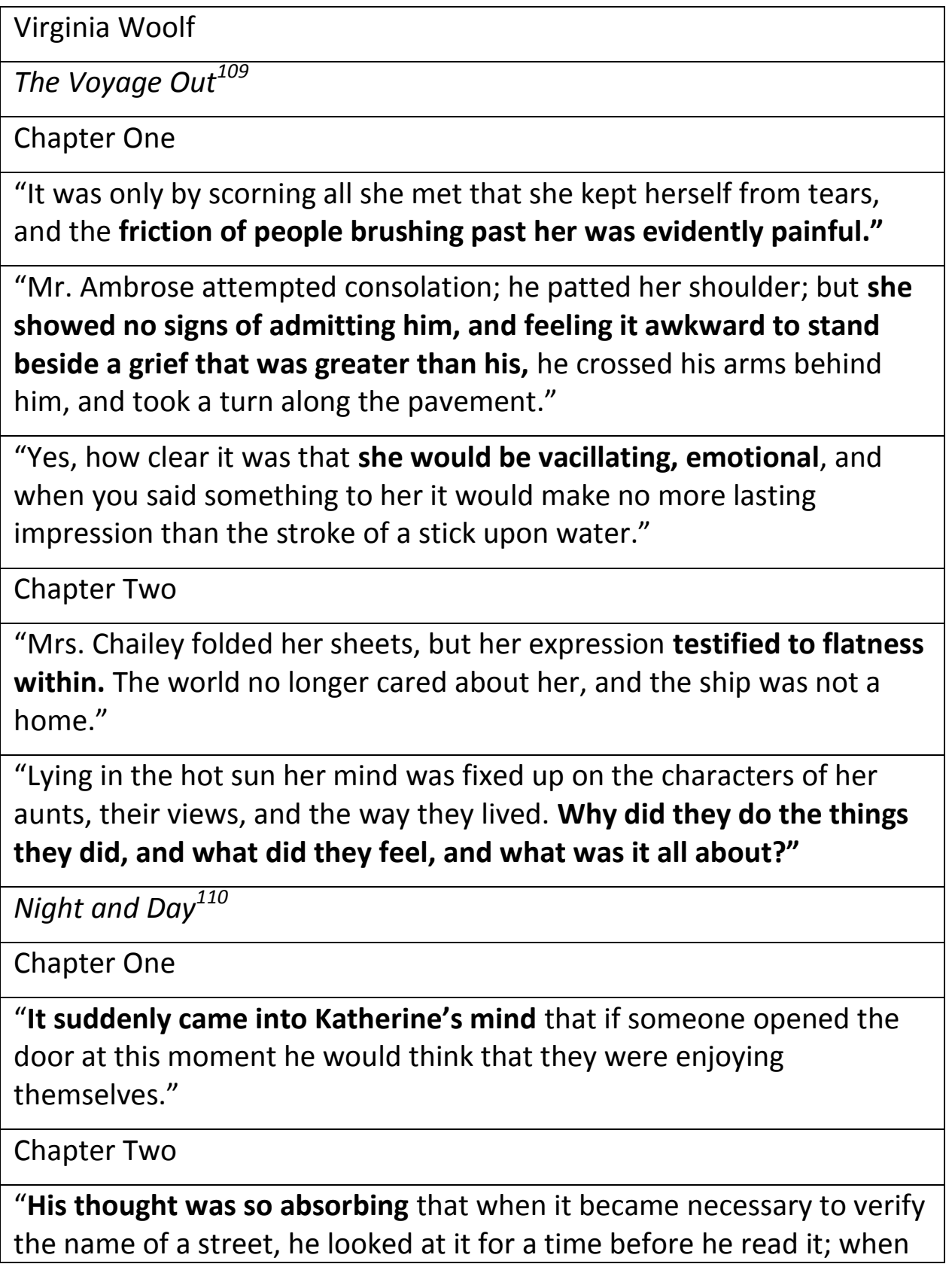

\footnotetext{
${ }^{109}$ www.gutenberg.org/files/144/144.txt

${ }^{110}$ www.gutenberg.org/files/1245/1245.txt
} 


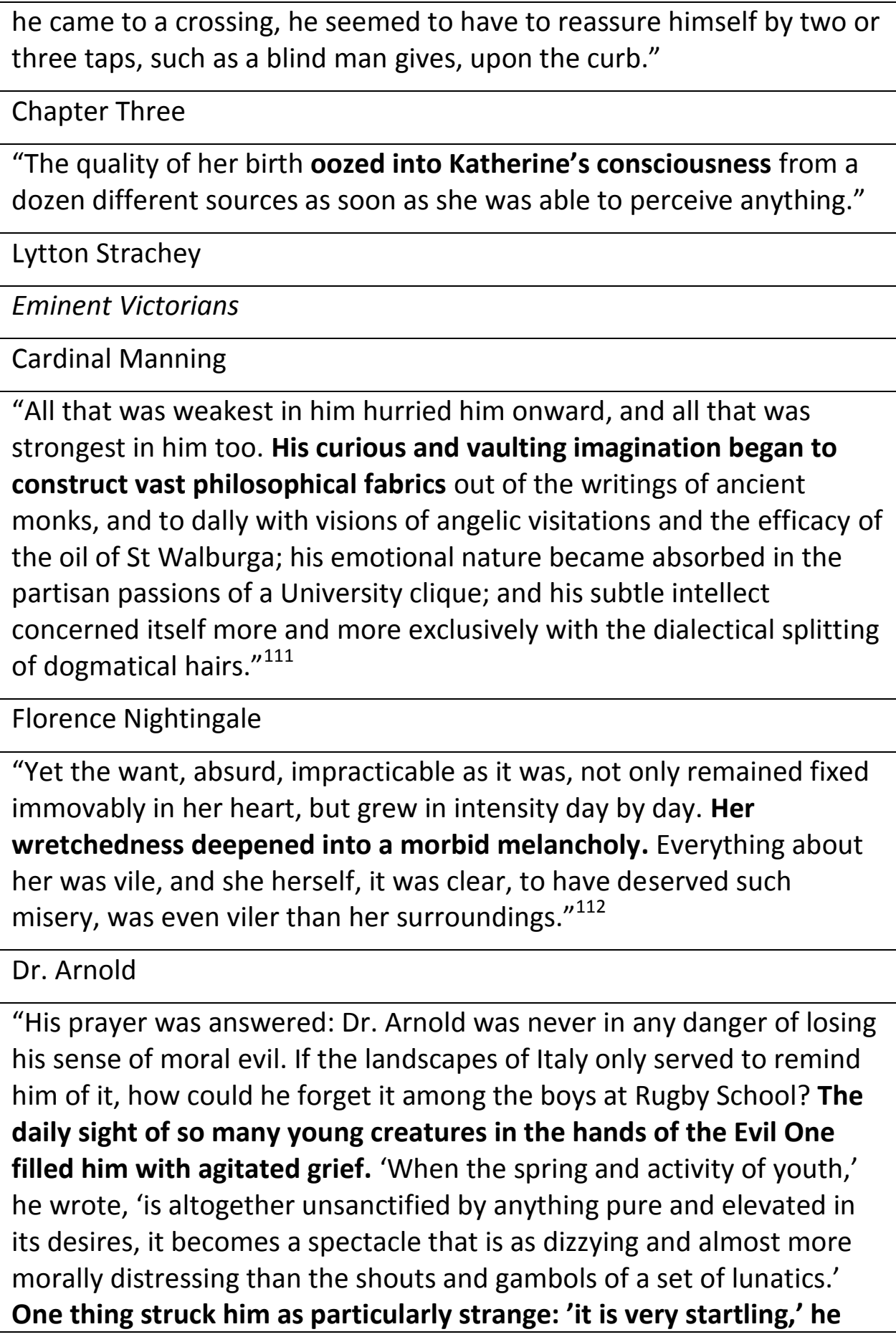

\footnotetext{
${ }^{111}$ Strachey, (1986, p. 33).

${ }^{112}$ Strachey, (1986, p. 119).
} 
said, 'to see so much sin combined with so little sorrow.' The

naughtiest boys positively seemed to enjoy themselves most." ${ }^{113}$

The End of General Gordon

"In his solitude, he ruminated upon the mysterious of the universe;

and those religious tendencies, which had already shown themselves, now became a fixed and dominating factor in his life. His reading was confined almost entirely to the Bible; but the Bible he read and reread with an untiring, an unending, assiduity." ${ }^{\prime 14}$

Maynard Keynes

The Economic Consequences of the Peace

Chapter Three - Clemenceau

"... and Clemenceau, silent and aloof on the outskirts - for nothing which touched the security of France was forward - throned, in his grey gloves, on the brocade chair, dry in soul and empty of hope, very old and tired, but surveying the scene with a cynical and almost impish air; and when at last silence was restored and the company had returned to their places, it was to discover that he had disappeared.

He felt about France what Pericles felt of Athens - unique value in her, nothing else mattered; but his theory of politics was Bismarck's. He had one illusion - France; and one disillusion - mankind, including Frenchmen, and his colleagues not least."115

Chapter Three - Wilson

"Yet the causes were very ordinary and human. The President was not a hero or prophet; he was not even a philosopher; but a generously intentioned man, with many of the weaknesses of other human beings, and lacking that dominant intellectual equipment which would have been necessary to cope with the subtle and dangerous spellbinders whom a tremendous clash of personalities had brought to the top as

\footnotetext{
${ }^{113}$ Strachey, (1986, p. 185).

${ }^{114}$ Strachey, (1986, p. 204).

${ }^{115}$ Keynes, (1919, pp. 28-29).
} 


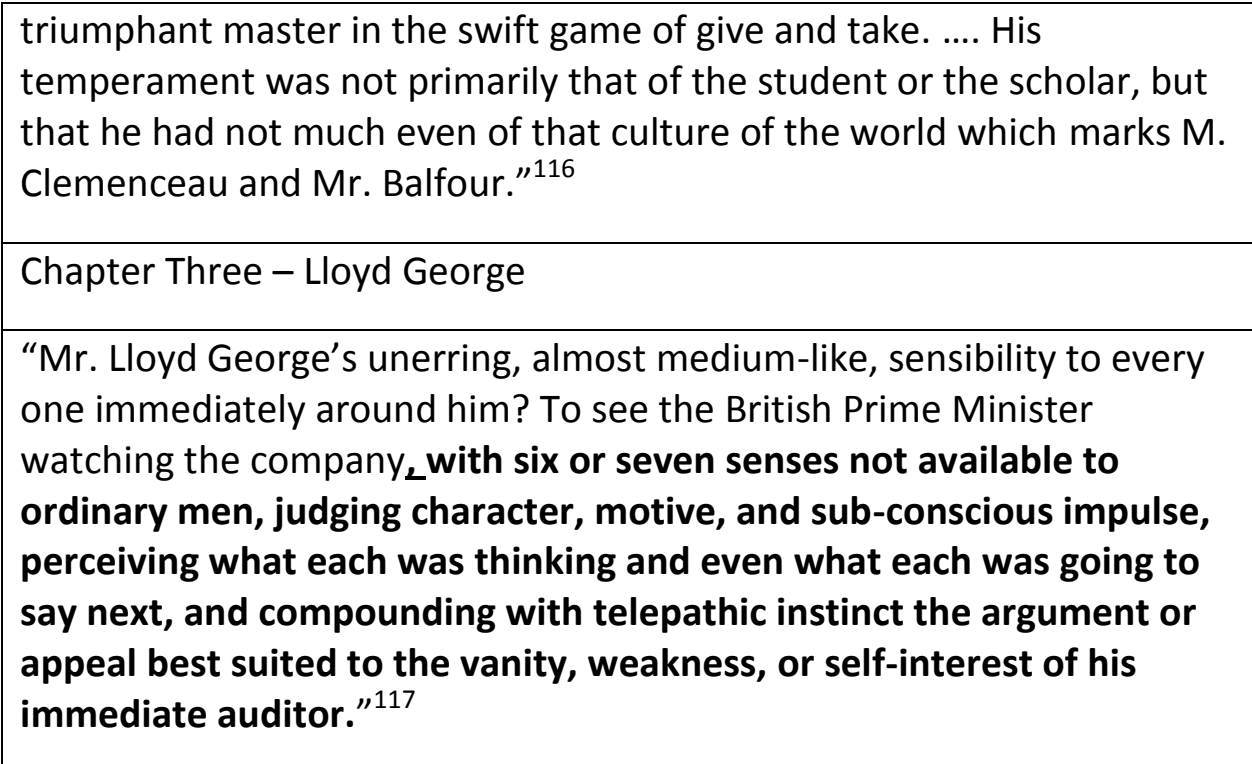

These examples show how each writer speculated on their character's psychological states of mind. Although it is not explicit how they influenced each other Skidelsky argues, 'something had to have changed in people's attitude to themselves and to the world for such [books] to have been conceived and written. ${ }^{118}$ This change was a transitional one that saw the rise of the twin movements of modernism and collectivism. ${ }^{119}$ Strachey had successfully used G. E. Moore's refutation of idealism to write a different style of biography that in turn was a criticism of Victorian ideals and was, argues Holroyd, to influence the style of The Economic Consequences of the Peace persuading Keynes to be 'more indiscreet than he was by nature and to have the courage to print what he would have said in conversation. ${ }^{120}$ According to Mini these texts almost

\footnotetext{
${ }^{116}$ Keynes, (1919, pp. 36-37).

${ }^{117}$ Keynes, (1919, p. 37).

${ }^{118}$ Skidelsky, (1992, p. 406).

${ }^{119}$ Skidelsky, (1992, p. 406).

${ }^{120}$ Holroyd, (1995, p. 428).
} 
certainly sharpened Keynes' belief - to which his own personal, Moore-inspired experiences were also leading him - that logic plays a limited role in human affairs. ${ }^{121}$

Virginia Woolf was also influenced by Moore and, arrived at the same conclusion that she too was trying to escape from customary modes of expression; hence her new mode of expression; 'psychological realism.' In her novels and essays she finds consciousness is a very elusive element to discover and expose and argues: 'It is no use trying to sum people up. One must follow hints, not exactly what is said, not yet entirely what is done.' People are organic and complex unities and 'of all futile occupations this of cataloguing features is the worst.' There is no essence of character, no unity, no 'basic flaw': everything is uncertainty and inconsistency. Everything is also unstable, the apparent calm may be shattered at any moment. Time is discontinuous, not homogeneous, and the controlled psychic state of Monday may give way to the horror and sudden crash of Tuesday. Keynes shared this 'catastrophic-view' of time, of its essential discontinuity and near-unintelligibility. A sudden 'outer' occurrence, that is, one 'exogenous' to the psyche of the character, a mark on the wall, is what jolts the mind into self-consciousness. These changing outer events in Woolf find their equivalent, according to Mini, in the unexamined events of The General Theory, such as a political speech, an unexpected bankruptcy, a rumour that sets off an irrational flight into liquidity, that cause the descent into depression by shaking the fragile psychological foundations of economic relations. $^{122}$

\footnotetext{
${ }^{121}$ Mini, (1991).

122 Mini, (1991).
} 


\subsection{Influence and Bloomsbury Friendships}

Although the surviving archives are silent on exactly how each writer influenced the other, what we know is that friendships were close, forged from regular contact with other Bloomsberries. We also know that among the literary set material and manuscripts were freely shared and circulated, each person seeking and incorporating feedback into their own works. For example, when Keynes was preparing for his follow up to Economic Consequences, A Revision of the Treaty, he had read sections to his friends, as he seemed to do quite often when preparing a manuscript. Virginia Woolf wrote to him:

Dear Maynard

Would you let us have your manuscript in order that we may read what we missed last night? It will be kept private and returned instantly. We think it just magnificent, and I can't say how much I envy you for describing characters in the way you do. ${ }^{123}$

Leonard Woolf also wrote to Keynes later in the same year:

Dear Maynard

I think this first rate and most amusing. I expect your psychological analysis of Wilson is absolutely correct. It explains everything. I hope you're doing Lloyd George. ${ }^{124}$

Keynes had written up a psychological profile of Lloyd George for Economic Consequences but had decided to omit it from the final publication. Only with his later publication of Essays in Biography (1933) did he provide a full character sketch of Lloyd George. It was worth the wait as Keynes painted the following picture:

\footnotetext{
${ }^{123}$ Virginia Woolf to Keynes, 3 February, 1921, King's College Archives, JMK/PP/45/353/3.

${ }^{124}$ Leonard Woolf to Keynes, 21 August, 1921, King's College Archives, JMK/PP/45/352/3.
} 
How can I convey to the reader, who does not know him, any just impression of this extraordinary figure of our time, this syren, this goat-footed bard, this half-human visitor to our age from the hagridden magic and enchanted woods of Celtic antiquity? One catches in his company that flavour of final purposelessness, inner irresponsibility, existence outside or away from our Saxon good and evil, mixed with cunning, remorselessness, love of power, that lend fascination, enthrallment, and terror to the fair-seeming magicians of North European folklore. ${ }^{125}$

Perhaps it was once again feedback from his mother that led to his decision not to include the fully prepared character sketch in Economic Consequences. In reviewing one of his draft manuscripts she had written:

My dearest John

Here is the remainder - on p. 188 your references to Sir S. L. won't do - it is rude. And on pp. 203,4, your remarks on Lord Summer approach libel - don't they? You really must be more careful. In looking back, I cannot feel quite sure that I eliminated all the nasty bits about Lloyd George - I hope I did, or that you will. You owe some loyalty to your Chief, even if you don't agree with him, and I am sure you will be happier afterwards if you keep within the bounds. Also spare the President where you can - I wish I could see the chapter again. Don't call him "poor" - and I am doubtful about the taste of the Nonconformist Minister comparison. Broadly speaking it is really important to be careful about international susceptibilities - so don't call the French preposterous - or call any "great" man wicked or wanton. The work will gain - not lose - by restraint. ${ }^{126}$

Although this advice did not stop Keynes publishing his character sketches his mother's advice once again had the effect of his toning down the more 'nasty bits.'

\footnotetext{
${ }^{125}$ Keynes, (CW, $X$, p. 23).

${ }^{126}$ FGK to Keynes, Undated, King's College Archives, JMK/EC/1/9.
} 
But, as important as the feedback was from friends and family the one friend who exercised the greatest influence on Keynes was Strachey. This had begun from the time of Keynes first serious work on Probability and continued to time of Strachey's death in 1931. In 1907 Strachey wrote to Keynes on his work on Probability:

I'm glad Probability is progressing. It certainly will be of immense importance when it is done. I talked about your theory of "self evidence" to Horon and became rather perplexed. He denied there was any such thing. Your simile of Berkley; dungheap really doesn't quite do because even you admit that when the mind isn't there some sort of a dungheap still exists, which I don't think Berkley would allow. $^{127}$

Both men reciprocated the habit of reading selected portions from manuscripts and sending each other drafts of books intended for publication and on matters related to literature in general. For example, Keynes wrote to Strachey in 1920: 'My experiences with a variety of translators have given me some reflections on English style I should like to talk about. ${ }^{128}$ They also followed and commented to one another on critical reviews of each other's works. Following the publication of Economic Consequences Strachey wrote to Keynes: 'I saw the translation of the Wilson part of your book in the Lowell Review. Not so bad, but the poor good man got it quite wrong once or twice. And how tame it is! Is that because it's in French, or because it's a translation? ${ }^{129}$

Then there was the habit of sending a copy of each other's texts as soon as they were being readied for general publication. On receiving an advance copy of Treatise on Probability, Strachey wrote to Keynes:

\footnotetext{
${ }^{127}$ Strachey to Keynes, 17 September, 1907, King's College Archives, JMK/PP/45/316/3/128.

${ }^{128}$ Keynes to Strachey, 17 May, 1920, King's College Archives, JMK/45/316/5.

${ }^{129}$ Strachey to Keynes, 12 May, 1920, King's College Archives, JMK/45/316/5.
} 
I am delighted to get the Treatise on Probability, which I have perused, minus the symbols, with a pleasure apparently independent of comprehension. I thought it full of interest - and so much of the incidental kind that really I believe even the absolutely "general reader" would enjoy it and be all the better for it. So far as I can judge the main conceptions are true and important; but my judgment is of a curiously theoretical one - I have "thoughts of things, which my thoughts but tenderly touch." I was pleased to see Karl Pearson severely lauded. Also it is gratifying to know that a formula reduces the argument from Design to ashes: an absurd thing I always thought it. Perhaps you might have referred en passant to Pascal's argument that it is worthwhile to believe in God because there is always a chance of exiting, as you do mention some analogous theories. The note on Lord Lister's treatment a priori and the "inevitable assumption about the wages" made me laugh. Dear me! The assumption is indeed all too inevitable. I note 4 misprints which may have escaped you ... I presume that 1000 years hence the manuals on English Literature will point out that it is important to distinguish between the two entirely distinct authors of the same name, one of whom wrote the Economic Consequences of the Peace, and the other $a$ Treatise on Probability. ${ }^{130}$

Four months later Keynes had also sent Strachey a copy of the Revision of the Treaty, sections of which Keynes had read out loud to his friends. Strachey wrote:

Dearest Maynard

I ought to have written days ago to thank you for the Revision of the Treaty. It is a great pleasure to have it, and it seems to me a second reading quite as good as I thought it when you read it aloud. It came out at a very opportune time!! But to judge from George's dreadful remarks about Reparations it doesn't seem to have produced an immediate effect! Or perhaps it has - perhaps he regards it as an encouragement to him to continue in his wicked ways.

${ }^{130}$ Strachey to Keynes, 25 August, 1921, King's College Archives, JMK/45/316/5. 
I gather, rather indirectly, that you're going to India pretty soon. I hope this will reach you before you depart, as I want to ask whether you think it would be suitable for me to dedicate my next production (such as it is) to you? I should like to, and will, unless you forbid it. I enclose a little work of the South Sea Bubble, also a note from Carrington. ${ }^{131}$

Keynes replied three days later to say he would be 'honoured and delighted by the dedication,' also informing Strachey his trip to India had been cancelled. Keynes never did make it to India, despite having worked in the India Office at the beginning of his career.

${ }^{131}$ Strachey to Keynes, 24 January, 1922, King's College Archives, JMK/45/316/5. 


\subsection{Summary - Influences on Keynes' Style}

Friendships forged in Bloomsbury acted as a life-long influence on Keynes. These friends kept up a continual cycle of sharing their work before and after it was published, inviting feedback and taking note of the respective success of each other's ventures. It should be no surprise, then, that aspects of each other's literary styles would have influenced the other. As far as the influence on Keynes and Economic Consequences was concerned there were to be important implications for how his book was received. For example, Keynes would have already taken note of how Strachey's use of triplets in his prose lent a degree of elaboration his book may not have otherwise had. Their friends and intellectual peers also undoubtedly influenced both men by the way in which psychology as a science and emerging discipline was being embraced. That Virginia Woolf had successfully pioneered a form of psychological realism in describing the characters in her novels seems to have had a direct influence on the ways in which both Strachey and Keynes wrote about the characters in their books. Ultimately, all three enjoyed publishing success and all three are considered as pioneers of original and new ways of writing in their respective genres:

Woolf; the novel, Strachey; biography, and Keynes; in the field of social science generally and economics specifically. 


\section{Chapter 8. The Legacy of Economic Consequences and Other Selected Works from the Early 1920s}

Following Economic Consequences Keynes came to play a public role he never downplayed or discouraged. He had a platform from which to share his views, theories, ideas and works. All were received with keen anticipation and analysed with interest by individuals outside the close-knit community of scholars and economists with whom Keynes shared professional interests, and among whom he became regarded as eminent.

The first significant work following Economic Consequences was A Revision of the Treaty. It was a sequel to Economic Consequences and brought up to date what had occurred in the continuing reparation debates and the workings of the commission set up to oversee implementation of the Treaty. While not explicitly dealing with the transfer problem, Revision was part of an evolving discussion around the theoretical nature of the reparations debate. The book also provided additional legal material about the Treaty. However, Keynes' core arguments remained. As far as Keynes was concerned the imposition of the reparation terms was morally, legally and economically wrong. Furthermore, Germany did not have the capacity to pay and by attempting to economically weaken Germany, all Europe faced an economic dark age. There was not a lot new in this, but what was new was Keynes' opening chapter and explanation of the importance he attached to public opinion ('outer' opinion) and how political and journalistic processes were necessary for shaping 'inner' opinion and why this was important for providing leadership in society.

The year following Revision, Keynes drew together a number of Manchester Guardian articles previously published as part of the "Reconstruction Supplements" and published them in book form as A Tract on Monetary Reform. For some time Keynes had believed money supply reform to be essential for stabilising the economy and this early prescription is of interest for a number of reasons: it shows the state of Keynes' thinking about monetary problems and the causes of inflation in the 1920s, providing a foundation 
for his later more theoretical work Treatise on Money; it demonstrates how technically good Keynes could be and provides one of the clearest explanations written of the determination of forward exchange rates; it shows Keynes already favouring flexible exchange rates as a means of independence in national economic policy; and, it demonstrates how Keynes developed his role as a public intellectual, always looking for ways to persuade and influence public opinion. 


\subsection{The Legacy of The Economic Consequences of the Peace}

As debate cooled during the 1920s, although briefly reignited with his 1922 Revision of the Treaty, it became clear Economic Consequences had established a legacy. Despite Keynes' claim this was a work of economics, debate still continues as to what his central message was. On close examination it is clear a number of the concerns outlined in Economic Consequences were the very issues that were to preoccupy him and his contemporaries throughout most of the 1920s. One of these was Germany's capacity to pay any form of reparation imposed on her. At the heart of this issue is what became known as the transfer problem. Keynes was the first to use the term but not until ten years following publication of his book. Thus begins the theoretical literature on the problem that continues to this day. ${ }^{1}$ Although Keynes' theoretical paper on the transfer problem was not published until 1929, the historical context is firmly grounded in the 1919 Treaty of Versailles. The international commission established as part of the Treaty arrangements was made responsible for determining the magnitude of German reparations. However its proceedings were marked by continuous dispute over Germany's willingness and capacity to pay. The initial figure settled on by the politicians was repeatedly revised downward, 'reflecting new realities and changing perceptions of economic and political conditions in Europe, until German reparations were all but eliminated following the Hoover Moratorium of $1931 .^{\prime 2}$ Keynes' theoretical position outlined in his 1929 paper was that a country required to make a fixed transfer of purchasing power to another would suffer a secondary burden in the form of a further decline in its purchasing power due to an induced deterioration in its international terms of trade. The secondary burden might be so large as to reduce the value of traded-goods production in the transfer-making country to an amount less than the required transfer. Samuelson argues, 'if the international

\footnotetext{
${ }^{1}$ Keynes, (Mar., 1929, pp. 1-7).

${ }^{2}$ Eichengreen, (1998, p. 684).
} 
demand curve of the receiving country were of elasticity of unity or less, there were fears that it would be quite impossible for the paying country to make the transfer competition would tend to turn the terms of trade indefinitely against her., ${ }^{3}$

Keynes' article resulted in extensive correspondence, comments and rejoinders in the Economic Journal. The most important exchanges were with the Swedish economist Bertil Ohlin. ${ }^{4}$ Ohlin responded to Keynes and argued that a secondary benefit, or terms of trade improvement, was as likely to occur. Whereas Keynes argued the terms of trade would deteriorate, Ohlin's and his followers' view was that a transfer implies no change in the terms of trade once income effects and purchasing power passing between the two countries is taken into account. As the debate matured during the 1930s and 1940s those who had previously thought a deterioration of the terms of trade was inevitable dropped this view in favour of a more careful formulation. Samuelson argues: 'A deterioration of the terms of trade of the paying country is not inevitable, but there is a strong presumption that the income elasticities of the different goods in the different countries will be such as to create some deterioration in the terms of trade. ${ }^{5}$ At the same time holders of Ohlin's views admitted that a change in the terms of trade might take place, but argued it could be in either direction and there was no presumption as to its direction.

As important as the transfer problem is for our understanding of the difficulties surrounding the reparations issue, Kent points out we should not allow ourselves to be distracted from what Keynes was really stressing. Keynes himself states, even before the Treaty was ratified, he was 'only concerned with tracing the consequences, per

\footnotetext{
${ }^{3}$ Samuelson, (1952, p. 279).

${ }^{4}$ Ohlin, (1929).

${ }^{5}$ Samuelson, (1952, p. 280).
} 
impossible, ${ }^{6}$ of carrying out the Treaty au pied de la lettre. ${ }^{7}$ Although A Revision of the Treaty, the sequel published early in 1922, summarised developments up to 1921, it was similarly intended to deliver what Keynes hoped would be 'the coup de grace to the problem' of the reparation issue. ${ }^{8}$ Keynes only became interested in serious economic analysis of the transfer problem some ten years following the events dealt with in Economic Consequences because his central message was unaffected; if the terms of the Treaty were imposed on Germany as set out in the Treaty then not only would Germany be economically destroyed but so too the rest of Europe, thus setting the scene for further European civil revolution and disruption.

Kent argues, rather than economic analysis and theory, Keynes was far more taken up with the politics surrounding the terms of the Treaty and this is what lies at the heart of his book. Kent argues,

scholars of one or other persuasions have regarded reparations as a pawn in a wider power struggle between the victors and vanquished and have not therefore been concerned to subject the origins and development of the reparation dispute to rigorous historical scrutiny. ${ }^{9}$

\footnotetext{
${ }^{6}$ Per Impossible reasoning proceeds from a patently impossible premise and is closely related to, albeit distinctly different from, reducto ad absurdum argumentation. Source: Internet Encyclopedia of Philosophy: www/irp.utm.edu/reductio.

${ }^{7}$ Keynes, (1919, p. 89).

${ }^{8}$ Kent, (1989, p. 6).

${ }^{9}$ Kent, (1989, p. 6). These two persuasions are, on the one hand, those who argue that in spite of American opposition, impossible reparation claims were fabricated by the European victors, in spite of American opposition, as part of a Carthaginian peace designed to eliminate Germany as a trade rival of Britain and so that Germany would not pose a threat to the future security of France. Adherents of this view usually go on to observe that this stratagem merely undermined the British economy and generated the turmoil and revanchism, which gave rise to Nazism in Germany and led eventually to the war of 1939-1945. On the other hand, this school of thought has been criticised by those who assign domestic causes to Hitler and his expansionism and assert that the treaty was not as Carthaginian, or Napoleonic, as the Germans claimed, that the financial wounds of the Weimar Republic were self-inflicted, and that the outbreak of war in 1939 was due if anything to the guilt complex of the peacemakers and their consequent appeasement of Hitler.
} 
Skidelsky also argues that the book is no mere technical treatise, stating: 'The writing is angry, scornful and rarely for Keynes, passionate: never again were his denunciations of bungling and lying, or his moral indignation, to ring so loud and clear. ${ }^{10}$ But to focus on the polemic is, for Skidelsky, to miss the purpose and point of the work. In short, Economic Consequences is a lucid account of the reparation problem through which Keynes is making a personal statement unique in twentieth century literature. He was, as has already been discussed above, staking a claim as the 'economist to be Prince' with 'all other forms of rule bankrupt.' The economist's vision of welfare, conjoined into a new standard of technical excellence, was to put up barriers to 'chaos, madness and retrogression. $^{11}$

While Skidelsky has some sympathy with the critics of Keynes' book, after all, the Treaty did accomplish some things of which a liberal would approve - the League of Nations, freedom of subject nations from autocracy, the dismemberment of Germany, he argues, we must understand the central theme of the book if we are to keep our judgment of the work in perspective. The theme was about how the war had damaged the delicate economic mechanism by which the European peoples had lived before 1914, and how the Treaty of Versailles, far from repairing this damage, had completed the destruction. Thus, as Keynes argued, the central theme is economic, not political. The war had destroyed Europe's economic organisation and with it shaken the social order by disclosing the 'possibility of consumption to all and the vanity of abstinence to many. ${ }^{12}$ For Keynes, the Malthusian devil had been set free, especially in Russia where famine killed many. ${ }^{13}$

\footnotetext{
${ }^{10}$ Skidelsky, (1983, p. 384).

${ }^{11}$ Skidelsky, (1983, p. 384).

12 Skidelsky, (1983, p. 386).

${ }^{13}$ Keynes used the term "Malthusian devil” to describe Malthus's (Reverend Thomas Robert Malthus, 1766 1834) argument that population growth sooner or later gets checked by famine and disease. Unlike some economists, Keynes did not dispute this view but rather argued that the Malthusian devil could be "locked ...Footnote continued on next page...
} 
Furthermore, all the belligerent governments had been forced by the war into a ruinous course of inflation, which was potentially fatal for capitalist economies. Keynes invoked Lenin who had said 'there is no subtler, nor surer means of overturning the existing basis of society than to debauch the currency.' For Keynes, a 'good peace' should have addressed these issues directly, which affected European victors and vanquished alike. Instead the treaty-makers produced what he called the Carthaginian Peace, whose effect would be to impoverish Europe. This result he attributed to two things, the inadequacy of statesmen's ideas, and the inadequacy of their characters. Skidelsky argues, 'Keynes' thesis, stated simply, is that the Big Three all gave politics precedence over economics. ${ }^{14}$ Keynes addressed this directly with what Skidelsky describes as his 'revolt of economics against politics'. The war had been fought in the name of nation, state, and emperor. But, Keynes argued, these were false gods, from whom he sought to divert allegiance towards economic tasks. Skidelsky also argues this message helped form the outlook of a new generation where 'the 1920s saw a new breed of economist-politician, who talked about the gold standard and the balance of trade as fluently as pre-war politicians had talked about the Two-Power standard and the balance of power. ${ }^{15}$ In other words the economic problems faced by all countries at the end of the war required a new breed of politician who took an interest in economics in ways not done by their predecessors.

Oswald Mosley (1896-1980) is an example of such an economist-politician. In 1925 he decided to equip the Labour Party with modern economic policy. With his then new Labour Party friend John Strachey (1901-1963) he wrote a 24-page pamphlet Revolution by Reason (1925). ${ }^{16}$ Both had been dismayed by the failure of the Labour government to

up" when economies are stable and healthy. During this period this was not the case in Russia where the "Malthusian devil" had been let loose.

${ }^{14}$ Skidelsky, (1983, p. 387).

${ }^{15}$ Skidelsky, (1983, p. 399).

${ }^{16}$ Skidelsky, (ODNB, 2004, 31477).

...Footnote continued on next page...

Page 336

8-Jun-11 
make any impact on the stagnating economy. They campaigned together for a more radical, expansionist approach, and they secured local Labour Party and ILP support for their so-called 'Birmingham Proposals' in 1925. Mosley had been the more dominant personality in the campaign and it was he who wrote up the proposals into the short pamphlet. Strachey, however, provided a more thorough theoretical rationale for their ideas and he also wrote a book with the same title as the pamphlet. In this he argued, by combining increases in the money supply with economic redistribution and the establishment of a state planning body, it was possible both to provide an incentive to manufacturers and to help the working classes.

Another example of an economist-politician during the 1920s is Winston Churchill (1874-1965) who was from 6 November 1924 to 4 June 1929 Chancellor of the Exchequer, and as such intimately concerned with the economy. ${ }^{17}$ While in principle he was a Gladstonian Liberal in financial policy, committed to free trade, strict economy in public expenditure, and balanced budgets, he is best remembered during this period for restoring the gold standard. The Bank of England, the Treasury, and the Conservative Party were delighted when it was announced in the budget of April 1925 the gold standard was to be restored at the pre-war parity of $\$ 4.86$ to the pound. Keynes and Beaverbrook had both warned Churchill against this step but Churchill, after conducting a thorough investigation into the arguments for and against, came to the conclusion a return to gold was inevitable and possibly right. However, the consequence, as forewarned by Keynes, was an overvalued pound, which had damaging effects on British export industries, including coal, and thus precipitated the general strike of 1926. In later years Churchill came to regard the restoration of the gold standard as a disastrous mistake.

Newman, (ODNB, 2004, 36337).

${ }^{17}$ Addison, (ODNB, 2004, 32413). 
Another politician who took an active interest in economics and enjoyed an eminent career in both politics and business was Robert Horne (1871-1940). ${ }^{18}$. In April 1921 he was appointed Chancellor of the Exchequer but was engaged with a threatened national coal strike so his predecessor, Austen Chamberlain, had to introduce the budget statement for that year. At this time the economic downturn had become severe, and intense pressure had developed from business, taxpayers groups, the Conservative Party, and Conservative newspapers for reductions in government expenditure and taxation. Cabinet Meeting Minutes of $2^{\text {nd }}$ August 1921 show how seriously Horne and his fellow cabinet members saw the situation. The meeting minutes recorded that virtually the entire meeting was taken up with discussion of the issue and Horne opened the meeting by recalling

that the prospective revenue had already necessitated a demand that the Government Departments should cut down expenditure by $20 \%$. The financial outlook, however, was such that in the near future further economies would be essential, and there was very little prospect of achieving this by ordinary departmental methods.19

Horne recommended a 'strong independent Committee' be appointed to find options to the crisis, which met with sharp divisions within the Cabinet, although by the end of the discussion it had been resolved the Prime Minister would appoint an independent Committee, the composition of which would be left to him. The subsequent nonministerial economy committee became known as the 'Geddes axe' because under the chairmanship of Sir Eric Geddes the committee advocated economies totalling $£ 87$ million although Cabinet decided on savings amounting to $f 52$ million. ${ }^{20}$ During his remaining

\footnotetext{
${ }^{18}$ Williamson, (ODNB, 2004, 33991).

${ }^{19}$ The National Archives: Catalogue Reference: CAB/23/26.

${ }^{20}$ Ramsden, (2005, p. 264).
} 
tenure Horne became the chancellor most associated with Treasury deflation and the financial constriction of reconstruction policies.

The activities of all these politicians' highlights how the economic concerns and turmoil of the 1920s meant an interest in economics was hard to separate from the political concerns of the day. But then, many political concerns were economic ones. In addition to politicians who took a particular interest in the economy, there were other non-economists such as Ezra Pound and T. S. Eliot, well known and highly regarded literary figures, who Skidelsky argues took on the role of 'economist-poets' ${ }^{21}$ A number of scholars acknowledge the importance literary figures placed on the subject of economics even if they seriously question the soundness of their economic views. ${ }^{22}$ For example, DeLong attacks Pound's views on usury on the basis it is 'bad' economics. If you are not able to change rates of interest, which compensate you for the risk you are taking, then, as a lender, you will only do business with people familiar to you, which means the typical working man is not going to find anyone who is prepared to lend to him. This means the working class is denied one of the principal luxuries of the capitalist class, the ability to make decisions about the timing of purchases of goods independently of the fixed timing of the arrival of one's income. DeLong argues, 'it turns out that this is a very valuable advantage to enjoy. Usury has been good in that regard. ${ }^{23}$

While the issue of usury also concerned T. S. Eliot, as a single issue it was not as important as the actual place of economics in people's lives. For him economics depended on right ethics. This was a theme Eliot progressively promoted through The Criterion,

\footnotetext{
${ }^{21}$ Skidelsky, (1983, p. 399).

${ }^{22}$ It is with some irony (perhaps) that Pound believed in the necessity of government intervention in the economy to bring about the 'perfect' capitalist state. Pound, however, rejected Keynes' views on government intervention because Keynes rejected debt-free financing of the government's needs. Davis, (1968, pp. 112-113).

${ }^{23}$ deLong, (2003, p. 1).
} 
which he founded in 1922 and edited until it closed down in January 1939. According to Eliot the theme of right ethics and the impact of economics on people's lives should take precedence over the issue of good or bad economics. Stevens argues this is what literary figures such as Pound and Eliot primarily concerned themselves with and adds, 'whether poets ever made good economists is debatable, but one would certainly not turn to the milieu of the 1920s if one wanted to make an argument for the affirmative. ${ }^{24}$ As diverse as economists, politicians and poets may appear to be from one another, the economic problems of the 1920s united these groups in their attempts to persuade opinions to take economics seriously.

Economic Consequences left little doubt Keynes was serious and committed to tackling post-war economic problems head on. It has led many, such as Elizabeth Johnson, to ask the question, was Keynes a scientist or politician? She argues for Keynes as a scientist who used political means of persuasion, whereas O'Donnell argues for Keynes as a politician because of his effective rhetoric. O'Donnell argues Keynes believed the essence of politics was its persuasive appeal to reason. He argues:

The central presuppositions of his view were centred on ideas, opinion, persuasion and reason, and that to effect lasting, non-violent social change it was sufficient to patiently disseminate reasonable views, which addressed and persuaded the intelligence of those who influenced affairs at whatever level. ${ }^{25}$

This was Keynes' constant motif. For example, in Economic Consequences he declared there was only one way of influencing 'the hidden currents' flowing beneath the surface of political history and this was 'by setting in motion those forces of instruction and imagination which change opinion.' The means were 'the assertion of truth, the unveiling

\footnotetext{
${ }^{24}$ Stevens, (1999, p. 1).

${ }^{25}$ O’Donnell, (1989, p. 274).
} 
of illusion, the dissipation of hate, and the enlargement and instruction of men's hearts and minds., ${ }^{26}$

Johnson argues that the use of phrases and statements such as these shows Keynes was 'a natural born and highly efficient, ever alert politician. ${ }^{27}$ However, Johnson is anxious to point out, while Keynes behaved in public like a working politician, in private he was a committed scientist who applied himself to solving problems that existing theory would not explain. She argues, 'at first, [Keynes] was content to dazzle by demonstrating a fuller knowledge of economic theory and statistics than his professional colleagues possessed. [He used this knowledge to] support different conclusions than their understanding of the economic orthodoxy led them to. ${ }^{28}$ But eventually Keynes' intellectual honesty and his concern for economic science led him to believe it was not the incompetence of the orthodox economists at fault, but the received theory itself. For Keynes, modifications within the framework of orthodox economics were not enough; a frontal attack on the framework was itself required. To this end his magnum opus the General Theory, published in 1936, was to herald this frontal attack. To this point Keynes' published works supports Johnson's view Keynes was both a politician and an economist, whose constituency was not electoral but intellectual. In short, in order to be a politician he had to be a scientist and this, as has been highlighted, meant he played the role of public intellectual with great success. This role was to continue for the remainder of his life. An examination of some of his selected works from the first half of the 1920 s is illustrative of how Keynes cemented his place as a public intellectual.

\footnotetext{
${ }^{26}$ O’Donnell, (1989, p. 188).

27 Johnson, (1974, p. 105).

${ }^{28}$ Johnson, (1974, p. 107).
} 


\subsection{Essays in Persuasion}

Essay in Persuasion, first published in 1931, included a selected variety of Keynes' literary output published during the 1920s. They reflected particular concerns from this period and ones about which he explicitly sought to persuade public opinion. The essays are all of a non-technical nature and include some of Keynes' most famous polemics of the period, including "The Economic Consequences of Mr. Churchill” and “Can Lloyd George do it?" Contemporaries and pupils remembered most vividly these and other pamphlets and excerpts of Keynes' works included in Essays, such as "The End of Laissez-Faire," and excerpts from Economic Consequences. ${ }^{29}$ He grouped his selected essays under three headings: The Treaty of Peace; Inflation and Deflation; and The Return to the Gold Standard.

In his introduction to the book Keynes made clear the intention of this particular collection of works: 'It was in a spirit of persuasion that most of these essays were written, in an attempt to influence opinion.' On reflection in 1931 he knew he was swimming against the tide of economic orthodoxy 'for I wrote many of these essays painfully conscious that a cloud of witnesses would rise up against me and very few in my support, and that I must, therefore, be at great pains to say nothing which I could not substantiate.' ${ }^{30}$ Yet, despite his confidence his views were right, he also believed the 'collected croaking's of a Cassandra' had not been able to influence the course of events in time. The title he wanted to use was Essays in Prophecy because, he believed, prophecy had been more successful than persuasion.

Perhaps his own perception was formed from the generally hostile reviews he received from reviewers who bristled at the 'I told you so' tone, which many of his essays displayed. For example, MacFadyen opened his review in International Affairs with: 'books

\footnotetext{
${ }^{29}$ Keynes, $(C W, I X$, p. xv).

${ }^{30}$ Keynes, (CW, IX, p. xvii).
} 
of the "I told you so" variety threaten to become the fashion' ${ }^{31}$ W. L. H. in Pacific Affairs commented, the twenty-five essays that make up the book 'make up this most stimulating and readable volume of "I told you so.",32 The tone also caused some reviewers to bristle and ruffled the feathers of some close contemporaries and friends. For example, Leonard Woolf thought Keynes displayed his cleverness too recklessly; Harold Laski accused Keynes of being an eighteenth century rationalist who ignored the fact that capitalism was unreformable, a criticism echoed by John Strachey. ${ }^{33}$ Ohlin had another view as to why others were suspicious of Keynes. In his review of Essays Ohlin argued, 'if the directors of the Bank of England and other bankers have refused to listen to Mr. Keynes' advice, the reason is, I think, to some extent this instinctive suspicion of the truly brilliant mind. ${ }^{34}$

In the same review Ohlin probably spoke for many readers when he asked:

I do not think that anybody can read Mr. Keynes' essays without asking: How can it be that a man whose power to analyse the pressing problems of to-day is so imposing, has been able to exercise so little influence on actual policy? Why has a man with so much success in prophecy - the real proof of his analytical ability - been so unsuccessful in persuasion ? $^{35}$

But Ohlin hastens to add, he does not believe this to be the case: 'I do not think that Mr. Keynes' writings have failed to influence the thoughts and ideas of men in power. He has set their minds to work in his direction, but too slowly to influence their action.' Ohlin argued that the thinking Keynes stimulated in the 1920s would influence economic thought and policy in the coming 1930s:

\footnotetext{
${ }^{31}$ McFadyean, (1932, p. 258).

${ }^{32}$ W.L.H., (1932, p. 905).

${ }^{33}$ Skidelsky, (1983, p. 674).

${ }^{34}$ Ohlin, (1932, p. 258).

${ }^{35}$ Ohlin, (1932, p. 258).
} 
I feel certain that this influence, which is already evident, will be considerable. To take one example, only the general willingness today even among bank managers to consider a managed paper currency as a real substitute for the gold standard must be no small extent due to the discussions around some of Mr. Keynes' essays. I think they will in the next 20 years work hand in hand with his Treatise on Money in preparing the ground for monetary reform. ${ }^{36}$

Reviewers of a later generation now look back and see Keynes' attempts at persuasion were every bit as successful as the prophecy. For example Skidelsky argues, 'in saying that his prophecy had been more successful than his persuasion, Keynes was selling himself short. ${ }^{37}$ The work of Keynes' pen had 'played its part in undermining old prejudices.' There was no serious attempt after 1931 to revive the gold standard, which is, argues Skidelsky, a tribute to Keynes' persuasion in the early 1920s. While The Times, champion of monetary orthodoxy, defended their position in 1925 as 'honour was at stake and worth the effort' but 'British industry failed to make the necessary adjustment,' from this point onwards Keynes found The Times open to him with his most important policy suggestions during the 1930 s appearing in its columns. ${ }^{38}$

A brief examination of a few of the economic policy prescriptions used in 1930s Britain highlights why his stocks were higher as a result of his efforts at persuasion in the 1920s. For example, the deflationary constraint of the gold standard had ended in the early 1930s and a decade of cheap money followed. The Keynesian agenda of the 1920s, applied in the 1930s, enabled Britain to escape the worst of the world depression. ${ }^{39}$ Keynes endorsed, and partly inspired, the cheap-money policy and its corollary, managing

\footnotetext{
${ }^{36}$ Ohlin, (1932, p. 259).

${ }^{37}$ Skidelsky, (1983, p. 431).

${ }^{38}$ Skidelsky, (1983, p. 432).

${ }^{39}$ At least according to Skidelsky, (1983, p. 433).
} 
sterling at a low rate of exchange with the dollar, which followed the gold-standard era. He applauded Chamberlain's conversion of $\mathrm{f2}$ billion of 5 per cent war loan to 3.5 per cent as 'a constructive measure of the very first importance,' not on budget-saving grounds, but for its effect on the long-term interest rate. Cheap money also facilitated a boom in private house building, which helped revive economic activity. Finally, he no doubt felt vindicated when reparations were finally cancelled at the Lausanne Conference in July 1932. After the Second World War, the victorious Allies made sure they did not repeat the mistakes of 1919 and as Skidelsky states, 'Keynes' persuasion prevailed. ${ }^{40}$

\subsection{A Revision of the Treaty}

The first three chapters of Essays in Persuasion came from Economic Consequences and covered the "Paris Conference" (Chapter 1, Introduction), "The Capacity of Germany to Pay Reparations" (Chapter 5, Reparation), and "Proposals for the Reconstruction of Europe" (Chapter 7, Remedies). The next two chapters came from A Revision of the Treaty and dealt with "The Change of Opinion" (Chapter 1, The State of Opinion) and "War Debts and the United States" (Chapter 6, Reparation, Inter-Ally Debt and International Trade, and Chapter 7, The Revision of the Treaty and the Settlement of Europe). In terms of argument there was little difference between Economic Consequences and A Revision. In his sequel Keynes had brought up to date what had occurred with the continuing reparation debate and the workings of the commission appointed to set, oversee and amend the terms of the Treaty as circumstances changed. The sequel also provided additional legal material around the Treaty and the Commission's terms but Keynes' core arguments remained: the imposition of the reparation terms was morally, legally and

\footnotetext{
${ }^{40}$ Skidelsky, (1983, p. 434).
} 
economically wrong; Germany did not have the economic capacity to pay anything but a token form of reparation and the bulk of that should only go to the worst affected countries, France, Belgium and Serbia; ${ }^{41}$ by attempting to economically emasculate Germany the whole of Europe was on the cusp of further disruption and revolution; the debt burden between the Allies, if not forgiven or reduced to a minimum would act as a brake on economic development, trade and growth, all necessary for restoring Europe to prosperity. The one exception to this covering of old, albeit updated ground was the introductory chapter in which Keynes outlined how he believed the process of influencing public opinion worked. It is not entirely clear why Keynes chose this particular book to outline these views but in any event the chapter on its own has served as a useful synopsis for future scholars in their understanding of how he subscribed so firmly to the importance of rhetoric and persuasion.

In this first chapter of The Revision Keynes gives a clear explanation for the importance he attached to public opinion and the political and journalistic processes helped mould opinion. In Keynes' view reform and change were products of discussion through which public opinion was formed and guided. This formation and guidance came through the persuasion of 'inner' and 'outer' opinion, which has been discussed in Chapter Three. Keynes also saw that 'inside' and 'outside' opinion 'can function as policy. ${ }^{42}$ Evidence of this can be found in two letters Keynes wrote to President Roosevelt at the time of the implementation of the New Deal, the first in December 1933, the other in June 1934. Houck argues a close reading of the text reveals

a highly nuanced integration of scientific principles with rhetorical practices - an integration upon which "economic recovery" is constructed and premised. More specifically, Keynes discursively constructs an economic recovery by combining scientific terminology

\footnotetext{
${ }^{41}$ Moggridge, (1992, p. 334).

42 Houck, (1999, p. 363).
} 
with an economic logic premised on the strategic use of presidential rhetorical practices. $^{43}$

Houck argues that one example is 'highly rhetorical,' when Keynes confidently asserts the mere act of the President's speech will engender recovery and on the subject of controlling the dollar's exchange rate, he advises

You can announce that you will control the dollar exchange by buying and selling gold and foreign currencies at a definite figure ... with a right to shift the parities at any time, but with a declared intention only so to do either to correct a serious want of balance in America's international receipts and payments or to meet a shift in your domestic price level relative to price levels abroad. ${ }^{44}$

In the concluding paragraph to his letter Keynes confidently claims

With these adaptations or enlargements of your existing policies, I should expect a successful outcome with great confidence. How much that would mean, not only to the material prosperity of the United States and the whole world, but in comfort to men's minds through a restoration of their faith in the wisdom and power of government! ${ }^{45}$

Although there is no record of Roosevelt's reaction to these letters, Keynes' correspondence seemed to have had an impact on US Treasury policy. The journalist Walter Lippmann wrote to Keynes on 17 April 1934 and informed him, 'I don't know whether you realize how great an effect that letter had, but I am told that it was chiefly responsible for the policy which the Treasury is now quietly but effectively pursuing. ${ }^{46}$ Houck also argues Keynes' ideas would have appealed greatly to the newly elected

\footnotetext{
${ }^{43}$ Houck, (1999, p. 356).

${ }^{44}$ Keynes, (CW, XXI, p. 296).

${ }^{45}$ Keynes, (CW, XXI, p. 297).

${ }^{46}$ Keynes, (CW, XXI, p. 305).
} 
President. Rhetoric, particularly presidential rhetoric, addressed to a mass audience, can "enliven the "animal spirits" and thereby provide a vital impetus to economic activity and economic recovery. ${ }^{47}$

Moggridge argues, Keynes' opening in The Revision with his views on 'inner' and 'outer' opinion has not received as much attention from scholars as might be expected, especially in light of Keynes' subsequent meetings with officials, ministers and MPs, public speeches, articles in the quality and popular press, all of which were designed to persuade the élite. ${ }^{48} \mathrm{O}^{\prime}$ Donnell is interested in explanations for the keen interest Keynes took in the forming of 'inner' and 'outer' opinion. He argues, the source of Keynes' views and actions in regard to the forming of opinion is to be found in his political philosophy. But, as O'Donnell points out, 'providing a detailed account of Keynes' political philosophy is a difficult task, for he set no explicit scheme of thought down in this area. ${ }^{49}$ While political theory formed part of his early reflections, it never dominated in the way that ethics, logic and probability did. Nor did he have a contemporary mentor in politics analogous to Moore in philosophy or Marshall in economics. Nevertheless his ethical philosophy generated a specific conception of politics, and he was politically active over many years, assisting Liberal campaigns in many elections, including those of 1906, 1910, 1923, 1924, 1928 and 1945, but refusing offers to stand as Liberal candidate in 1920 and 1928 in order to concentrate on writing. As with much of his political activity a great deal of this writing was focused on forming opinion, whether of the 'inside' or 'outside' variety. Furthermore the bulk of this shaping and forming of opinion occurred as part of his supplementary career as a journalist. O’Donnell explains, 'journalism, with its 'daily task of persuasion'

\footnotetext{
${ }^{47}$ Houck, (1999, p. 363).

${ }^{48}$ Moggridge, (1992, p. 370).

${ }^{49}$ O’Donnell, (1989, p. 273).
} 
figured prominently, not only through newspapers and radio but also through the establishment and direction of political weeklies and journals. ${ }^{50}$

This supplementary journalistic career began in 1921 and helped shape the way in which he presented his views in The Revision. The background to this career lay in the series of meetings between European premiers and their officials to sort out the unfinished business of the Peace Treaties. Between 1920 and 1922 there were over twenty such meetings. A large part of The Revision is taken up with the detail from these meetings. As 1920 progressed these meetings spent more and more time on the reparation issue, which the Treaty had left unclear in several ways. For example, the size of Germany's ultimate liability for reparations required a decision by the Reparations Commission. Also, although Germany had to provide a payment of $£ 1,000$ million in cash or kind before 1 May 1921, there were the problems of devising a scheme for the payment of her remaining liabilities under the Treaty, of devising the means and channels whereby the payments might be made, and, given that Germany's payments would be less than her potential liabilities under the Treaty, of settling the distribution of payments. Following a conference of experts meeting in Brussels in December 1920, which came up with a proposal for reparations payments, another meeting took place in Paris at the end of January 1921 to try to decide the ultimate size of the payments. Once the results of the Paris Conference were known, C. P. Scott of the Manchester Guardian, 'which had become something of a liberal conscience on such matters, asked Keynes for a signed article. ${ }^{51}$

Keynes wired an article to Manchester the next day, critical of the scheme whereby Germany would make a series of payments of $f 100$ million a year in the first two years, rising to $f 300$ million after 11 years, where they were to remain for another 31 years, plus the equivalent of 12 per cent of her export earnings. In case of default, the

\footnotetext{
50 O’Donnell, (1989, p. 276).

${ }^{51}$ Moggridge, (1992, p. 368).
} 
scheme allowed the Reparations Commission to intervene in the conduct of Germany's public finances. Keynes' remarks were widely quoted and commented upon in England, and extracts from the article were immediately cabled to the US by the press services. Following this first experience of journalism, Keynes started to take the idea of further excursions more seriously. In the course of negotiations for Lytton Strachey's move from the publishers Putman to Harcourt Brace for Strachey's new book Queen Victoria, Keynes asked Alfred Harcourt about placing future articles in the American press. At this stage he was thinking of articles 'about questions arising from the peace treaty or reparation, about the foreign exchanges, or about such general financial and economic topics as the present industrial depression ... of a type intended for the general reader. ${ }^{52}$ By the spring of 1921 he was placing most of his articles overseas as well as in Britain and 'the next year would see even more elaborate arrangements as his relationship with the Manchester Guardian developed. ${ }^{53}$

During 1921 Keynes' journalistic forays tended to be set around the successive stages in the reparations saga: Germany's counter-proposals to the Paris scheme made at the London Conference at the beginning of March; the subsequent Allied ultimatum; the French statement of intent over the occupation of the Ruhr; the Reparations Commission's decision as to Germany's liabilities under the Treaty; and the Allied reparation scheme presented as an ultimatum at the second London Conference in May. However the highlight of his journalistic output in 1921 was a series of five widely syndicated articles for The Sunday Times, which appeared between 21 August and 18 September under the title "Europe's Economic Outlook." Keynes had been asked to do the articles in May, but, despite the temptations of $f 600$ for a week's work, 'he was determined to put them off until he was through with Probability. ${ }^{, 54}$ The articles dealt

\footnotetext{
${ }^{52}$ Keynes, (CW, XVII, p. 217).

${ }^{53}$ Moggridge, (1992, p. 369).

${ }^{54}$ Moggridge, (1992, p. 369).
} 
with Germany's ability to pay the new, imposed, reparations settlement; the effects of the settlement on world trade; the causes of the current depression; and the prospects for wages and the settlement of war debts. At the end of the year Keynes was to use these reparations articles in The Revision.

Between publication of Economic Consequences and A Revision fallout by way of critical comment, correspondence, and reference to a 'Keynes' view of the 'reparation problem,' first raised in Economic Consequences, rumbled on throughout 1920 and 1921. For example the Swedish economist Knut Wicksell wrote to Keynes on $15^{\text {th }}$ October 1921, following a newspaper article written by Keynes on reparations and Germany's capacity to pay. While agreeing with Keynes it was impossible for Germany to pay reparations in the near future without some special assistance, he disagreed with his estimation of Germany's general capacity to pay. Wicksell wrote:

of course I do not understate the noble-mindedness of your attitude towards a former enemy but I think it has carried you too far. Somebody must pay for the war, it would hardly be a moral right if, as the consequences of a too great liberality, France and England were ruined by the war and Germany thriving. ${ }^{55}$

Keynes replied 11 days later:

In the particular articles in question I was intending to deal with the near future. But you are quite right in supposing that I do not limit my general argument to the near future, and that in my book I was speaking of Germany's capacity to pay in general. This topic, however, as times goes on, needs fuller arguments and arguments of rather a different character from those which apply to the very near future; and in my short newspaper articles I had not space to embark on such large topics. ${ }^{56}$

\footnotetext{
${ }^{55}$ Keynes, (CW, XVII, p. 279).

${ }^{56}$ Keynes, (CW, XVII, p. 280).
} 
For some time Keynes had been thinking of the 'fuller arguments' he had mentioned to Wicksell. In June 1921 he had proposed a revised edition of Economic Consequences to Alfred Harcourt. Harcourt suggested a sequel instead and the outcome of their correspondence through the summer and autumn was a plan for a new book. The title Keynes eventually decided on was A Revision of the Treaty being a sequel to The Economic Consequences of the Peace.

On January 10, 1922 Keynes' Sequel was published. This was, argues Moggridge, 'a much less impassioned book than Economic Consequences of the Peace. ${ }^{, 57}$ In Keynes' estimation the book was not another Economic Consequences and on the day he wrote the last words he thought it 'honourable and workmanlike, but not sensational. ${ }^{58}$ The spectacular success of Economic Consequences assured The Revision a ready audience. Reviewers, remarking on the sober tone and the 'lack of pyrotechnics' compared to its predecessor, prophesied that the book would have fewer readers, but on the whole were more approving. ${ }^{59}$ There was, of course, a mixed reception to the book, as there would be for all Keynes' subsequent works. The response from The Times provides an example of this mixed reception. On the one hand the editorial, published on the same day as the book, under the heading "A Revision of the Treaty; Mr. Keynes' View; Is Germany Guiltless?" praises Keynes' gift

of interesting his readers in problems that are at once vital and obscure. Few people can think in millions; fewer still can make intelligible and attractive to others the play of their ideas amid the noughts that trail off from intelligible units into the vague. Mr. Keynes

\footnotetext{
${ }^{57}$ Moggridge, (1992, p. 370).

${ }^{58}$ Moggridge, (1992, p. 372).

${ }^{59}$ Keynes, (CW, XVII, p. 297).
} 
can, and that is one of the secrets of the success of his first book on the Peace. He suggested a point of view. ${ }^{60}$

Many reviewers echoed The Times' praise of Keynes' abilities with argument and numbers, but many would also concur with the conclusion to the review that

stated barely, the proposed revision (suggested by Keynes in his book) is based on a full admission by the Allies that they have been economically defeated by the obstructive tactics of Germany. If we have really come to that, then those who will may take comfort in Mr. Keynes' plausible arguments that will obscure with their iridescence our sad condition. The peace he promises is subtly suggestive of greater perils to come. ${ }^{61}$

Furthermore, in the same editorial The Times explicitly suggested the wide readership of The Revision was due more to Keynes' personality and style than 'the soundness of his arguments.' Both books offered a 'brilliant performance' but again one is baffled by the interesting problem of Mr. Keynes' personality. Is he an economist, an artist, a politician, or a detached philosopher? He is all these in turn, perhaps all at once. Yet the new book explains something that was not clear when its predecessor was published. Then Mr. Keynes had a particular advantage. He had the distinction of a man opposing views that appeared to be commonplace. He has not that advantage now. The views he enunciated in "Economic Consequences of the Peace" have become commonplace, not only among the Germans and their friends, but in certain circles in this country. The sequel suffers from the success of its predecessor. Mr. Keynes has a horror of the banal. He is certainly anything but banal in the new book, but he has to move swiftly and

\footnotetext{
${ }^{60}$ Steed, Wickham, (ed.), “A Revision of the Treaty; Mr. Keynes’ View; Is Germany Guiltless?” Jan. 10, 1922, The Times, p. 9.

${ }^{61}$ Steed, Wickham, (ed.), “A Revision of the Treaty; Mr. Keynes' View; Is Germany Guiltless?” Jan. 10, 1922, The Times, p. 9.
} 
trippingly to escape from the reflection of banality that his own previous words have cast. ${ }^{62}$

It is unlikely Keynes would have objected to The Times' observation that he 'had a horror of the banal.' Keynes, after all, knew the linguistic "pyrotechnics" and the "flashy bits" he often resorted to, gained attention and once he received a reaction the chances of influencing public opinion were higher.

62 Steed, Wickham, (ed.), “A Revision of the Treaty; Mr. Keynes' View; Is Germany Guiltless?” The Times., Jan. 10, 1922, p. 9. 


\subsection{A Tract on Monetary Reform}

The productive relationship with the Manchester Guardian reached a point of maturity in 1922 with the "Reconstruction Supplements" published by Keynes and other authors. Later the next year on $11^{\text {th }}$ December 1923 Keynes published A Tract on Monetary Reform. In the Tract Keynes drew heavily on his own contributions to the Supplements. This publication of The Tract is important for two reasons. First, the reactions to Economic Consequences and Revision suggest Keynes had been effective in reaching out to 'outer' opinion as much as he had 'inner' opinion. On the other hand, reaction to A Tract received far more reaction from individuals who formed the 'inner' opinion. All belonged to élites and Keynes' call for reform and change led to vigorous debate in élite circles. However, Keynes ensured he kept up his direct appeals to the public so that 'outer' opinion would more easily align with 'inner' opinion. The second important aspect of the publication of $A$ Tract is, it marked a shift from international economic concerns to domestic issues Keynes felt needed attention.

As already argued, following World War One countries that had previously formed the successful and stable group of nations operating fixed exchange rates under the gold standard found conditions at home greatly altered. Apart from the more obvious physical restoration difficulties outlined by Keynes, price levels, for example, were greatly misaligned from one country to another. The Bank of England had stood for firm leadership before the war but came out of it in a weakened state and with no contender capable of taking its place. Inflationary pressures had also become a significant problem for politicians and policy makers. Many economists and politicians believed the answer lay in a return to the gold standard, a return to a time when domestic and international stability had been taken for granted. Keynes however had other ideas.

He had already argued the world could not return to the use of policies in play before the war since too much had changed. Keynes had come to believe the answer lay in fundamental monetary reform. He called for an end to any notion of a return to the gold standard but rather argued for the implementation of a managed paper currency 
regime. Whereas prosperity had followed the successful management of fixed exchange rates in the gold standard era of the late nineteenth, early twentieth centuries, Keynes believed in the new world context the focus should be on a more rigorously managed domestic economic environment with the exchange rate set adrift to self-regulate international trading conditions. In his preface to $A$ Tract Keynes outlined his reasons for this book:

One is often warned that a scientific treatment of currency questions is impossible because the banking world is intellectually incapable of understanding its own problems. If this is true, the order of society, which they stand for, will decay. But I do not believe it. What we have lacked is a clear analysis of the real facts, rather than ability to understand an analysis already given. ${ }^{63}$

For today's economists the Tract is of interest for four reasons. First, it shows the state of Keynes' thinking about monetary problems and the causes of inflation in the early 1920s, and provides a starting point for his progress through the Treatise on Money to The General Theory. Second, it provides one of the clearest expositions ever written of the determination of forward exchange rates. Third, it shows Keynes already in the 1920s favouring flexible exchange rates as a means of allowing independence in national economic policy. And, finally it is illustrative of how Keynes played out his role as a public intellectual and highlights his motivation in seeking to 'persuade' and influence public opinion.

But what is of most importance in The Tract are the links between theory and policy underpinning Keynes' views on monetary policy. For example Moggridge and Howson argue, 'for every change in the problem at hand came new proposals growing out of previous theory or, if previous doctrine could not accommodate the new situation,

\footnotetext{
${ }^{63}$ Keynes, (CW, IV, p. xiv).
} 
shifts in theoretical position. ${ }^{64}$ Patinkin agrees with this assessment of The Tract and suggests The Tract is not really a book. Rather it is a short and somewhat unsystematic revision and elaboration of the series of articles on post-war economic policy Keynes first published in 1922 in the "Reconstruction Supplements" of the Manchester Guardian Commercial. ${ }^{65}$ Not that this concerns Patinkin but rather reinforces his view that, as with much of his work in the area of monetary theory, Keynes is really concerned with practical policy problems and their related concern with the empirical aspects of these problems. Fodor takes a different view and argues 'the view that the Tract is basically a collection of articles which Keynes had previously published in the Manchester Guardian is mistaken. ${ }^{66}$

Not only did Keynes add new material while writing the Tract, argues Fodor, but he also completely changed his standpoint on the main issues involved, from the desirability of returning to the gold standard to the possibility of improving the fate of mankind by abolishing unemployment. Fodor attaches such importance to this singular work of Keynes he believes we can date the time Keynes became a 'Keynesian' to the summer of 1923 when he was transforming the Reconstruction Supplements into The Tract. While Keynes' subsequent road to breaking with the 'classical' economists was a difficult process, Fodor argues, the publication of The Tract pinpoints the period when Keynes publicly departed from orthodox economists and began to defend opinions which, at the time, 'were definitely associated with those of monetary cranks. ${ }^{67}$ From this moment Fodor believes Keynes' goal was clear: how to control the trade cycle.

\footnotetext{
${ }^{64}$ Moggridge and Howson, (1974, p. 247).

${ }^{65}$ Patinkin, (1975, p. 254).

${ }^{66}$ Fodor, (1990, p. 97).

${ }^{67}$ Fodor, (1990, p. 97).
} 
The Tract, Skidelsky argues, has 'the special atmosphere' of all of Keynes' economic journalism. It both reveals esoteric knowledge and profanes sacred wisdom. ${ }^{68}$ As with Economic Consequences, the Tract was full of 'blasphemies' designed to amuse Bloomsbury and provoke the complacent. For example when he calls the gold standard a 'barbarous relic' he knew the reaction such language would provoke from those who clung determinedly to the notion a return to gold was what was needed to restore economic stability. In an elaborate joke he bewails the afflictions of the virtuous saver, wiped out by inflation, "he who neither spent nor "speculated," who made "proper provision" for his family, who sang hymns to security and observed most straightly the morals of the edified and the respectable injunctions of the worldly wise. ${ }^{69}$ But beneath the technical argument and ironic language of the Tract were a series of connected propositions that would inspire Keynes' economic work for the rest of his life. For Keynes economic health was too important to be left to laissez-faire. Economic management must become part of the modern science of government, not a tool of vested interests.

\footnotetext{
${ }^{68}$ Skidelsky, (1992, p. 159).

${ }^{69}$ Keynes, (CW, IV, 1971, p. 16).
} 


\subsection{The Economic Consequences of Mr. Churchill}

It has been highlighted Keynes argued against a return to the gold standard in the Tract but once it was reality he turned his attention to changes that could be made to the management of monetary policy, which underpinned the return without having to abandon the gold standard. Keynes wrote to the editor of The Times, Geoffrey Dawson, offering him a series of articles on the consequences of the return to gold. Dawson accepted, subject to seeing the final version. When he had he wrote back to Keynes:

I am rather embarrassed by these articles. They are extraordinarily clever and very amusing; but I feel that, published in The Times at this particular moment they would do harm and not good. Whether you like it or not, the gold standard has now been restored beyond all hope of recall. This being so; it seems to me that the only thing to be done is to make the best of it. I do not in the least mind publishing criticism of the Government in this or any other respect; but three solid articles seem to me to be rather over-doing it. ... I really am reluctantly driven to the conclusion that I cannot take them as they stand, and that you had better let them loose elsewhere. ${ }^{70}$

Keynes had, as was to be expected in any of his writing, used a number of rhetorically flashy phrases to get the reader's attention and it was these that no doubt caused Dawson some discomfort. For example Keynes sarcastically referred to the Prime Minister, Stanley Baldwin, as 'Queen Baldwin' in reference to 'a furtive restriction of credit by the Bank of England [that] can be coupled with vague cogitations on the part of Mr Baldwin (who has succeeded to the position in our affections formerly occupied by Queen Victoria) as to whether social benevolence does not require him to neutralise the effects of this by a series of illogical subsidies. ${ }^{71}$ While politicians are often seen as fair game for such attacks, most other individuals and sector interests Keynes deemed as being at fault did

\footnotetext{
${ }^{70}$ Keynes, (CW, IX, p. 225).

${ }^{71}$ Keynes, (CW, IX, p. 225).
} 
not escape his colourful rhetoric. For example, when referring to his belief that Churchill's experts misunderstood and underrated the technical difficulty of bringing about a general reduction of internal money values, Keynes accused them of dwelling in 'the imaginary academic world, peopled by City editors, members of Cunliffe and Currency Committees et hoc genus omne, where necessary adjustments follow "automatically" from a "sound" policy by the Bank of England. ${ }^{172}$

But Keynes took Dawson's advice and next wrote to Lord Beaverbrook, the proprietor of amongst other newspapers the Evening Standard, on 17 July 1925 offering Beaverbrook the rights to publish the three articles at a rate of $£ 50$ per article:

If you are interested in the proposal in principle I can send you copies of the articles to-morrow morning. In my opinion they are good journalism and are matters of popular interest. ... The thesis of the first article [under the general title of 'Unemployment and Monetary Policy,' I. The Diagnosis] is that Winston's policy has committed us to reducing everyone's wages $2 /$ - to the $f$. The thesis of the second article [II. The Policy of the Bank of England] is that the Bank of England's policy of credit restriction is a policy of bringing about the above result of deliberately intensifying unemployment. The third article [III. The Alternative Courses of the Government] makes two suggestions for treating the situation in a different way, compatibly with remaining on the gold standard. ${ }^{73}$

The Evening Standard published them on 22, 23 and 24 July. Keynes expanded the articles into a pamphlet, which the Hogarth Press, owned by Leonard Woolf, published less than a

\footnotetext{
${ }^{72}$ Keynes, (CW, IX, p. 214). The Cunliffe Committee was named after the Committee's Chairman, Walter Cunliffe (1855-1920) who was Governor of the Bank if England from 1913 to 1918. The purpose of the Committee was to provide recommendations on the post-World War One transition of the British economy. The Committee reported in 1918; "it is imperative that after the war, the conditions necessary for the maintenance of an effective gold standard should be restored without delay."

${ }^{73}$ Keynes, (CW, XIX, p. 417).
} 
week later under the title The Economic Consequences of Mr. Churchill. Chapters I, II and V correspond to the original articles.

As with most of Keynes' published works, The Economic Consequences of Mr. Churchill created considerable controversy and through a variety of correspondence, published reviews and political comments it is clear Keynes remained firm in his approach to the need for economic management and the need for forethought rather than instinctive reactions to economic problems:

The truth is we stand mid-way between two theories of economic society. The one theory maintains that wages should be fixed by reference to what is 'fair' and 'reasonable' as between classes. The other theory - the theory of the economic juggernaut - is that wages should be settled by economic pressure, otherwise called 'hard facts,' and that our vast machine should crash along, with regard only to its equilibrium as a whole, and without attention to the chance consequences of the journey to individual groups.

The gold standard, with its dependence on pure chance, its faith in 'automatic adjustments,' and its general regardlessness of social detail, is an essential emblem and idol of those who sit in the top tier of the machine. I think that they are immensely rash in their regardlessness, in their vague optimism and comfortable belief that nothing serious ever happens. Nine times out of ten, nothing really serious does happen - merely a little distress to individuals or to groups. But we run a risk of the tenth time (and are stupid into the bargain), if we continue to apply the principles of an economics, which was worked out on the hypotheses of laissez-faire and free competition, to a society, which is rapidly abandoning these hypotheses. $^{74}$

In summary, from the time Economic Consequences appeared until the publication of The Economic Consequences of Mr. Churchill Keynes was better known as a publicist and passionate crusader than a scholar extending the 'frontiers of the subject.' Within his chosen specialisation, monetary economics, 'in the Cambridge of the early 1920s A. C.

\footnotetext{
${ }^{74}$ Keynes, (CW, IX, p. 224).
} 
Pigou, Frederick Lavington and Dennis Robertson were more active, if less popularly known.' ${ }^{75}$ Keynes' contribution to monetary economics in the first half of the 1920s had come from his journalism and his Tract, itself a reworking of his articles in the Manchester Guardian Commercial Reconstruction Supplements. Moggridge argues that to this point Keynes had not seriously begun to analyse the major issues in his field of specialisation. However, this period, perhaps best thought of as his "crusading" phase, when Keynes had 'a reputation as a publicist rather than a scientist - a balance of reputation that was to last for some time,' an important foundation was laid for his later and substantial academic book on monetary theory, Treatise on Money (1930). ${ }^{76}$

\footnotetext{
${ }^{75}$ Moggridge, (1992, p. 433).

${ }^{76}$ Moggridge, (1992, p. 433).
} 


\subsection{Summary: The Legacy of Economic Consequences}

If the first five years of the 1920s had laid an important foundation for Keynes' later more scholarly and theoretical works, they had also served as an important period in Keynes' life as he firmly cemented himself in the minds of 'inside' and 'outside' opinion. Although at the end of the 1920s he felt he was more a prophet than a persuader of opinion, he was, by 1925, a public intellectual in every sense of the word, whose views always courted controversy and heated discussion, but more importantly paved the way for reform and fundamental change.

Three years after Economic Consequences had so provocatively criticised and condemned the Treaty of Versailles, the Allied political leaders who presided over its framing, and the ways in which the document sowed the seeds for further civil revolution, The Times could only criticise The Revision as 'anything but banal.' The assertion was that what Keynes had so thoroughly condemned in late 1919 was now in 1923 accepted as commonplace opinion.

Keynes himself did not quite see it this way. He still railed against the failure of politicians, economists and policy makers whom he accused of not understanding the heavy albeit continually changing burden of reparations that continued to divide and destabilise Europe. He also continued to take a dim view of the failure of leaders to deal effectively with the various sources of economic instability still plaguing post-war Europe. Inflation, a direct result of insufficient taxation during the war years, still hung like a spectre over many European countries; disparate price levels between trading nations proved resistant to correction and constituted a barrier to global equilibrium; and unemployment for many European countries remained stubbornly high and unstable with consequent labour and social unrest accompanying it.

During this period Keynes came to be seen as a crusader for social justice and a publicist for his causes, labels he happily accepted. However, what really drove him to keep speaking out, was a belief things did not have to be the way they were. He had called 
for a one-off, sensible reparation payment at the end of the war as a remedy to what he considered a hopeless and unworkable Treaty agreement. He also appealed to the Allies for the settlement of all inter-Allied war debts. If both had been acted on in a timely manner Keynes believed Europe, and the world, could quickly recover and return to prosperity, albeit under different terms and conditions than had existed before the war. But, having failed to persuade opinion on these issues, Keynes then spent the early 1920s trying to convince his 'inside' and 'outside' listeners that monetary reform was needed to address the economic instability caused by unresolved debt burdens, inflation, price disequilibrium, and unemployment. He counselled against a return to the pre-war gold standard, called for an abandonment of uncontrolled laissez-faire economic policies, and advised implementation of a managed money supply system. There was also an appeal for a return to firm leadership similar to that provided by the pre-war Bank of England. Before being weakened by the war the Bank of England had ensured a managed and controlled money supply system, tied to gold convertibility, and stable trading conditions. This time around Keynes argued against linking the money supply system to gold because he could see those wanting to return to a gold standard failed to grasp the need for corresponding monetary reform where the price level, volume of business activity and quantity of money itself should be determined by community spending and controlled by varying the interest rate. What mattered to him was the capacity for and management of credit creation that with or without gold convertibility needed strong central monetary management.

That Keynes lived to see many of these 1920s unorthodox views become received economic orthodoxy demonstrates his powers of persuasion were every bit as potent as his prophecy. This is the most important legacy of Economic Consequences . It is hard to conceive what greater importance can be attributed to the activities of a public intellectual. 


\section{Chapter 9. Conclusion}

Ideas communicated to the public by economists are often misunderstood. For example, Keynes consistently maintained many of his critics did not understand the central message of Economic Consequences and much of the reaction to the book supports what Solow calls "ideas that turn to mush." ${ }^{1}$ Keynes claimed Economic Consequences was a serious work of economics that provided a set of economic solutions he believed could head off the economic apocalypse he foresaw if the terms of the Treaty were not changed, and governments did not put aside self-interested nationalistic and imperialist ambitions. Critics often judged the book as nothing more than political propaganda and accused Keynes of being a pro-German sympathiser, who exaggerated the extent of Germany's problems and capacity to pay. These same critics also failed to grasp Keynes' gravest concern that revenge and the economic weakening of Germany would lead to an economic dark age. Even to the present day there is a view Keynes exaggerated the extent of the problems facing Europe and there are critics who argue the central message of Keynes' book is political rather than economic.

If this criticism was taken as a measure of success, it could be argued Keynes was unsuccessful in communicating his ideas. However, this argument is flawed because the very nature of the information dissemination process in democratic societies encourages criticism and a process of falsification to ensure messages are transmitted in ways intended and best explained. While Keynes' critics were many and vocal there were also others who did grasp Keynes' central ideas and over time scholars such as Moggridge and Skidelsky have done much to provide explanations in support of Keynes. This dissertation builds on these explanations and supports the view that Economic Consequences was a serious work of economics and Keynes' ideas have been successful in bringing about change and reform.

\footnotetext{
${ }^{1}$ Solow, (1989).
} 
There are two parts to this conclusion. First is a summary of the dissertation's main points, which addresses the primary subject, how economic ideas are communicated. The second part argues this dissertation makes an important contribution to a wider understanding of Keynes as a public intellectual as well as Economic Consequences as an economic text. The examination of the ways Keynes used statistics, a literary criticism of the book and an examination of the influences on Keynes' writing style have previously not been undertaken to the depth undertaken in this dissertation. Furthermore, our knowledge of how economic ideas are communicated, especially to non-economists, can better be explained in light of this research. The author intends to build on this research by applying the tools of literary criticism to other important works of Keynes', especially those where Keynes wrote for a broad audience.

As a result of this analysis of Economic Consequences this dissertation also establishes a better understanding of how economic ideas can be communicated successfully. First, Keynes demonstrated economic ideas can be effectively communicated without undermining the scientific exactitude of his ideas. Second, Keynes' activities as a public intellectual demonstrate written ideas require methods and means of dissemination to ensure ideas are communicated successfully. Third, Keynes argued there are different audiences for whom the message must be 'tuned' to ensure persuasion. Fourth, economic ideas can be communicated without an economist having to compromise his or her scientific principles. Finally, scientific exactitude notwithstanding, communication style is important in conveying a message.

\subsection{Chapter Summary}

The first part of this dissertation examines The Economic Consequences of the Peace and contemporary reactions to the book. A number of themes run through the text with the most important ones argued in considerable depth and often supported by a number of statistics. Keynes' central economic argument was that the reparations figures proposed at Versailles were unrealistic and economically harmful for all Europe. Proposed figures ranged from $£ 3,000$ million to $£ 24,000$ million, which were in addition to a number of 
measures already taken, such as immediate forfeiture of shipping capability, designed to reduce Germany's economic capability for waging war again. Keynes proposed a total reparation of $£ 2,000$ million payment be made by Germany, the proceeds to go to the countries worst affected by the conflict, such as France and Belgium. Furthermore he proposed a complete forgiveness of all inter-Allied debts to would enable Europe to quickly restore itself to economic prosperity. Only Britain and the United States would have been faced with net debt write-offs and all countries would have been in a position to operate with balance sheets clear of an on-going weight of debt.

Keynes, however, was pessimistic about these proposals being accepted. He had been appalled at the way in which the Allied leadership manipulated commitments made to honour the Armistice's Fourteen Points and the incompetence, deception, and impotence of the Allied leaders to put in place a reparation scheme aimed at restoring Europe's economic fortunes. He believed the way in which reparations were to be imposed was vengeful and went well beyond Germany's capacity to pay. He argued this heralded a bleak and apocalyptic economic future for Europe and the wider world economy.

Chapter Three examines Keynes' role as a public intellectual and how he successfully communicated his ideas. First, there is a discussion about what it means to be a public intellectual and why Keynes meets most definitions. Second, the importance of cultural and environmental influences was discussed and how these helped shape Keynes' style and method of communication. Finally, the processes and ways of communicating economic ideas are examined so as to better understand how some intellectuals are successful while others are not. The chapter closes with a synopsis of a selection of economists, Smith, Ricardo, Mill, Marx, and Marshall, who have established a tradition of economists as successful public intellectuals and highlights how Keynes stands on the shoulders of other eminent economists.

The next chapter deals with the economic context within which Economic Consequences was written. Context is important because what may be applicable in one 
environment or set of circumstances may be unworkable in another. The success of the gold standard from 1870 to the early twentieth century but its failure in the mid-1920s is illustrative of this. Keynes was especially cognisant of the importance of context to the point where his critics often accused him of changing his mind. His response was that this was necessary if the right economic solutions were to be applied to a problem. In Economic Consequences he provides an example of this when he dealt with European prosperity and issues of convergence before the war and the ways in which the economic dislocation of the war meant Europe could not return to its pre-1914 status. Rather, new and radical economic solutions had to be found if Europe was to return to stability and prosperity within a short time frame.

Chapters Five to Seven analyse Keynes' claim that Economic Consequences was a serious work of economics and examine the ways in which Keynes' writing style enabled him to communicate successfully. The first of these chapters is an examination of how Keynes used statistics descriptively and rhetorically to support his arguments. Chapter Six is a literary criticism of Keynes' prose and poetry, which shows how his use of metaphors, allusions and analogies had an economic point. Chapter Seven examines some of the influences that shaped Keynes' unique and successful communication style.

Chapter Eight examines how Keynes spent the first few years following publication of Economic Consequences establishing himself as a public intellectual calling for reform and change to areas of the economy that concerned him most. The primary legacy of Economic Consequences is that it brought to the forefront of public awareness Keynes and his ideas and enabled him to better persuade an alignment of 'inside' and 'outside' opinion.

\subsection{Dissertation Contribution}

The contribution of this dissertation is an economic historical analysis combined with literary criticism, previously not attempted, of Economic Consequences. This has enabled a set of conclusions to be made that make it difficult to refute the central ideas of Keynes' book and supports his claim that Economic Consequences was a serious work of 
economics. Even the 'flashy bits,' as Keynes called them, were all developed in support of his primary economic concerns. Furthermore, the research in this dissertation has provided a set of insights that addresses how economic ideas are communicated.

First, Keynes demonstrated economic ideas can be successfully communicated without undermining the scientific exactitude of those ideas. When using the tools of literary criticism, central ideas can be interpreted with confidence. Second, Keynes has shown through his activities as a public intellectual, written ideas require methods and means of dissemination, which enable the message to be transmitted as the writer intends. Keynes was explicit in his attempts at persuasion and as a student of the classics and rhetoric he understood the importance of metaphors and writing style as important means for communication.

Third, there are different audiences within the public sphere for whom the message must be 'tuned' so as to ensure persuasion. Keynes dealt with this in his analysis of 'inner' and 'outer' opinion. He was interested in reaching an educated audience and so drew on metaphors, allusions and analogies he knew would trigger the "imaginative cosmos" of his readers. Keynes believed in the importance and responsibility of the élite's ('inner') leadership role, so he looked for any opportunity to communicate with politicians, officials and businessmen. In a democracy Keynes also knew how important it was to directly appeal to 'outer' opinion if the public were to be persuaded to change. This was also important because public opinion invariably influenced 'inside' opinion.

The fourth finding is that ideas can be communicated without an economist having to compromise his or her scientific principles. Keynes relied heavily on official statistics in support of his arguments and it is this more than any other factor which addresses the more serious of the charges against Keynes, namely, he exaggerated the numbers. There is no doubt persuasion was foremost in his mind and his statistics were used to fit his rhetorical agenda. However, deliberate exaggeration, and certainly the possibility of fraudulent use of numbers, seems a remote possibility. Such suggestions would cast doubt on the activities of the Treasury and similar official bodies, whose members would need to 
have been complicit in any deliberate attempts at exaggeration. Furthermore, apart from the complaints of Treasury colleagues at what they saw as an insider breaking ranks, there is no evidence the Treasury laid any official complaint for misuse of its numbers.

The final research finding is, scientific exactitude notwithstanding, communication style is extremely important in conveying a message. Keynes brought together three important elements in his writing, enabling him to effectively communicate his ideas: he understood the importance of rhetoric and how it needed to be used so his audience could be persuaded; his use of metaphors, allusions and analogies demonstrates why he so successfully reached his target audience; and he absorbed a number of significant influences that led to the development of his own unique style. 


\section{Bibliography}

\section{Primary Sources}

Angell to Keynes, 20 July 1919, King's College Archives, JMK/L/19/43.

Bagehot, Walter, (ed.), (9 April, 1870), "Foreign Correspondence," The Economist, pp. 448449.

Barnes, Thomas, (24 October, 1823), “News," The Times, p. 2.

Benn, William/Hansard/House of Commons/8 February 1922.

Blackwood, William (ed.), (February, 1920), “Musings and Method: Economic Nonsense The Real Wickedness of the Peace," Blackwood's Magazine, No. MCCLII, Vol. CCVII, pp. 287-300.

C. Melchoir to J.M. Keynes, 19 December 1919, King's College Archives, JMK/EC/2/1/65.

Chamberlain, E. R., 2 June 1982, “Eminently A. L. Rowse," The Daily Telegraph, p. 15.

Dawson, George Geoffrey, (ed.), (19 November, 1918), "Armistice Terms: Another German Protest: "Economic Conditions Menaced"," The Times, p. 6.

Dawson, George Geoffrey, (ed.), (27 March, 1915), "German Change of Tone: A War of Exhaustion," The Times, p. 8.

Dawson, George Geoffrey, (ed.), (3 April, 1918), "Enemy Economic Conditions: Austrian Hardships: Jealousy of Hungarian Plenty," The Times, p. 4.

Delane, John, (July 06, 1865), “Election Intelligence," The Times, p. 9.

Draft Manuscript of Economic Consequences held in the King's College archives; JMK/EC/9 (box 14).

ECP Correspondence Archives, Undated, King's College Archives, JMK/EC/1/2.

Eddie Marsh to J.M. Keynes, 15 December 1919, King's College Archives, JMK/EC/2/1/27.

FGK to Keynes, Undated, King's College Archives, JMK/EC/1/9.

Gilbert Murray to J.M. Keynes, 17 December 1919, Yatscombe, Boar's Hill, Oxford, King's College Archives, JMK/EC/2/1/48.

Harmsworth, Esmond/Hansard/House of Commons/14 April 1920.

Headlam-Morley, James Wycliffe, (15 January, 1920), "The Economics of the Peace," The Times Literary Supplement.

Page 371

8-Jun-11 
Hirst, Francis Wrigley, (ed.), (31 December, 1910), "The Coming Year," The Economist, p. 1324.

Keynes to Strachey, 10 April, 1907, King's College Archives, JMK/PP/45/316/3.

Keynes to Strachey, 11 March, 1906, King's College, King's College Archives, JMK/PP/45/316/2/155.

Keynes to Strachey, 17 May, 1920, King's College Archives, JMK/45/316/5.

Keynes to Strachey, 21 March, 1909, 6 Harvey Road, Cambridge, King's College Archives, JMK/PP/45/136/4/136.

Keynes to Strachey, 22 July, 1908, India Office, Whitehall S. W., King's College Archives, JMK/PP/45/316/4/46.

L. Strachey to J.M. Keynes, 16 December 1919, The Mill House, Tidmarsh, Pangbourne, King's College Archives, JMK/PP/45/316/5/64.

Leonard Woolf to Keynes, 21 August, 1921, King's College Archives, JMK/PP/45/352/3.

Marr, Andrew, 30 April 1996, “Who will fill the intellectual vacuum?” Independent, p. 12.

Marshall, Alfred, (15 February, 1886), Letter to the editor, The Times, p. 13.

Marshall, Alfred, (July 1907), “Alcoholism and Efficiency," The Times, p. 12.

Mitchell-Thomson, Sir W./Hansard/House of Commons/12 February 1920.

Original Manuscript of Economic Consequences, JMK/EC/8.

Parmoor, Baron/Hansard/House of Lords/1 November 1921.

Parmoor, Baron/Hansard/House of Lords/22 December 1919.

R. G. Hawtrey to J.M. Keynes, 18 December 1919, Elm Park Gardens, S.W. 10., King's College Archives, JMK/EC/2/1/56.

R. Kenna to J.M. Keynes, 27 December 1919, Munstead House, Goldaming, King's College Archives, JMK/EC/2/1/129.

Roberts, George/Hansard/House of Commons/15 March 1920.

Samuel, Herbert/Hansard/House of Commons/10 February 1920.

Steed Wickham, (ed.), (13 February, 1920), "Mr. Balfour on the Situation," The Times, p. 13.

Steed Wickham, (ed.), (13 February, 1920), “Mr. Balfour's Reply,” The Times, p. 17.

Steed, Wickham (ed.), (11 February, 1920), "Treaty before the Senate," The Times, p. 17. Page 372

8-Jun-11 
Steed, Wickham (ed.), (13 February, 1920), "The State of Europe," The Times, p.12.

Steed, Wickham (ed.), (13 February, 1920), "Mr. Wilson and the Treaty," The Times, p. 13.

Steed, Wickham (ed.), (5 January, 1920), “A Critic of the Peace," The Times.

Steed, Wickham, (ed.), "A Revision of the Treaty; Mr. Keynes' View; Is Germany Guiltless?” Jan. 10, 1922, The Times, p. 9.

Steed, Wickham, (ed.), (14 February, 1920), "Interpreter's Stories," The Times, p. 16.

Steed, Wickham, (ed.), (16 February, 1920), The Times, p. 10.

Steed, Wickham, (ed.), (19 February, 1920), "Reparation and Settlement," The Times, p. 10.

Strachey to Keynes, 1908, King's College Archives, JMK/PP/45/316/4.

Strachey to Keynes, 1 July, 1907, Lancaster Gate, King's College Archives, JMK/PP/45/316/3/81.

Strachey to Keynes, 12 May, 1920, King's College Archives, JMK/45/316/5.

Strachey to Keynes, 17 September, 1907, King's College Archives, JMK/PP/45/316/3/128.

Strachey to Keynes, 21 July, 1908, Besize Park Gardens, Hampstead, King's College Archives, JMK/PP/45/316/4/45.

Strachey to Keynes, 21 October, 1907, Belsize Gardens, King's College Archives, JMK/PP/45/316/3/149.

Strachey to Keynes, 23 March, 1906, Villa Henrietta, Menton-Garavan, King's College Archives, JMK/PP/45/316/2/171.

Strachey to Keynes, 24 January, 1922, King's College Archives, JMK/45/316/5.

Strachey to Keynes, 25 August, 1921, King's College Archives, JMK/45/316/5.

Strachey to Keynes, 27 November, 1905, Lancaster Gate, King's College Archives, JMK/PP/45/316/1/191.

Strachey to Keynes, 7 July, 1910, Belsize Gardens, King's College Archives, JMK/PP/45/316/4/163.

The National Archives: Catalogue Reference: $\mathrm{CAB} / 23 / 26$.

Virginia Woolf to Keynes, 3 February, 1921, King's College Archives, JMK/PP/45/353/3. 
Walsh, Dr. Walter, (18 January, 1920), "The Economic Consequences of the Peace;" or "The Doom According to Keynes," The Free Religious Movement, Address No. 142 in Steinway Hall, p. 7.

Whibley, Charles, (April, 1917), “A Retrospect," Blackwood's Magazine, 201, p. 433.

Withers, Hartley, (ed.), (12 October, 1918), "What Sort of Peace?” The Economist, p. 443.

Withers, Hartley, (ed.), (17 January, 1920), "Germany - prospects for 1920 - Expenditure and Taxes - Bourse Conditions in 1919 - Price Inflation - Employment - Coal Troubles," The Economist, p. 16.

Withers, Hartley, (ed.), (27 December, 1919), The Economist, p. 1179.

Withers, Hartley, (ed.), (December 27, 1919), "The Peace Treaty," The Economist, pp. 1192-1193. 


\section{Secondary Sources}

Adams, Stephen, (1970), The Homosexual as Hero, Vision, London.

Adelstein, Richard., (1991), "The Nation as an Economic Unit: Keynes, Roosevelt, and the Managerial Ideal," Journal of American History, 78, pp. 160-187.

Adler, Jacob H., (June, 1961), "Pope and the Rules of Prosody," PMLA, Vol. 76, No. 3.

Albright, Daniel, (1997), "Yeats's figures as reflections in Water," from Quantum Poetics: Yeats, Pound, Eliot and the Science of Modernism, Cambridge University Press, Cambridge.

Aldcroft, Derek H., (1978), From Versailles to Wall Street 1919-1929, University of California Press, Berkeley.

Aldcroft, D. H. and S. Morewood, (1995), Economic change in Eastern Europe since 1918, Edward Elgar, Brookfield, U.S.

Alexander, Jeffrey C., (Oct. 2005), "Public Intellectuals and Civil Society," paper prepared as keynote address for Public Intellectuals and Europe - European Public Intellectuals? Sociological Perspective, UCD Dublin.

Alford, B. W. E., (1996), Britain in the World Economy Since 1880, Longman, London.

Amariglio, Jack and David F. Ruccio,(1999), "Literary/Cultural 'Economics,' Economic Discourse, and the Question of Marxism," The New Economic Criticism: Studies in the Intersection of Literature and Economics, ed. Martha Woodmansee and Mark Osteen, Routledge, London, pp. 381-400.

Anderson, Mark Alan, (2003), "Macbeth: Sympathy for the Devil," Idea. http://w4.nkcsd.k12.mo.us/ manderso/educ/writing/macbeth.pdf.

Angus, H. F., (Feb. 1947), "The Carthaginian Peace - or The Economic Consequences of Mr. Keynes," Canadian Journal of Economics and Political Science, Vol. 13, No. 1, pp. 133134.

Anonymous, (1846), Address of the Committee of the Society for the Diffusion of Useful Knowledge, Charles Knight \& Co.

Anonymous, (1827), "Diffusion of Useful Knowledge," Mechanics' Magazine, Saturday, 5 May.

Arrow, Kenneth, (1969), "Classificatory Notes on the Production and Transmission of Technological Knowledge," American Economic Review, 59, No. 2 (May), pp. 29-35.

Ashe, Geoffrey, (2003), Book of Prophecy: From Ancient Greece to the Modern Day, Orion Books, London. 
Aspers, Patrik, (Oct. 1999), "The Economic Sociology of Alfred Marshall: An Overview," American Journal of Economics and Sociology, Vol. 58, No. 4, pp. 651-667.

Aspromourgos, Tony, (1988), "The Life of William Petty in relation to his economics: a tercentenary interpretation," History of Political Economy, 20:3, pp. 337-356.

Backhouse, Roger E., and Bradley W. Bateman, (Winter 2009), "Keynes and capitalism," History of Political Economy, Volume 41, No. 4, pp. 645-671.

Backhouse, Roger E. and Steven G. Medema. "laissez-faire, economists and." The New Palgrave Dictionary of Economics. Second Edition. Eds. Steven N. Durlauf and Lawrence E. Blume. Palgrave Macmillan, 2008. The New Palgrave Dictionary of Economics Online. Palgrave Macmillan. 03 April 2011 <http://www.dictionaryofeconomics.com/article?id=pde2008_L000232> doi:10.1057/9780230226203.0925

Bagehot, W., (1858), Estimates of some Englishmen and Scotchmen, London.

Baines, Dudley, (1994), “European emigration, 1815-1930: looking at the emigration decision again," Economic History Review, XLVII, 3, pp. 525-544.

Balliet, Conrad A., (Dec. 1965), "The History and Rhetoric of the Triplet," PMLA, Vol. 80, No. 5.

Ban, A., (Oct., 1879), “John Stuart Mill," Mind, Vol. 4., No. 16, pp. 520-541.

Barnard, C., (1958), The Function of the Executive, Cambridge, MA.

Barnes, B., (1982), T. S. Kuhn and Social Science, Macmillan, London.

Bartholomew, David J., (1995), "What is Statistics?" Journal of the Royal Statistical Society. Series A (Statistics in Society), Vol. 158, No. 1, pp. 1-20.

Beales, H. L., (1934), “Revisions in Economic History: I. The "Great Depression” in Industry and Trade," Economic History Review, Vol. 5, No. 1, pp. 65-75.

Bell, Daniel, (1976), The Cultural Contradictions of Capitalism, Basic Books, New York.

Berend, Ivan T., (2006), An Economic History of Twentieth-Century Europe,' Cambridge University Press, Cambridge.

Berend, Ivan T. and György, Ranki, (1974), Economic Development in East Central Europe in the $19^{\text {th }} \& 20^{\text {th }}$ Centuries, Columbia University Press, New York.

Berghan, Volker Rolf, (1987), Modern Germany: Society, Economy, and Politics in the Twentieth Century, Cambridge University Press, Cambridge.

Berman, Marshall, (1982), All That Is Solid Melts into Air: The Experience of Modernity, Simon \& Schuster, New York.

Page 376

8-Jun-11 
Bigelow, Gordon, (2003), Fiction, Famine, and the Rise of Economics in Victorian Britain and Ireland, Cambridge University Press, Cambridge.

Blaug, Mark, (1958), Ricardian Economics: A Historical Study, New Haven: Yale University Press

Blaug, Mark, (1986), Great Economists before Keynes, Wheatsheaf Books, Brighton, Sussex.

Blaug, Mark, (ed.,) (1991), Adam Smith (1723-1790): Volume 1, Edward Elgar Publishing Limited, Aldershot, Hants.

Blaug, M., (1992), The Methodology of Economics: Or How Economists Explain, $2^{\text {nd }}$ ed., Cambridge University Press, Cambridge, UK.

Blaug, Mark, (September 1994), "Recent Biographies of Keynes," Journal of Economic Literature, Vol. 32, No. 3, pp. 1204-1215.

Bonar, James, (Nov., 1911), "The Economics of John Stuart Mill," Journal of Political Economy, Vol. 19, No. 9, pp. 717-725.

Bordo, M. and F. Kykland, (1995), "The Gold standard As a Rule: An Essay in Exploration," Explorations in Economic History, 32, pp. 423-464.

Bornstein, Diane D., (1977), An Introduction to Transfomational Grammar, Winthrop Publishers, Inc., Cambridge, Mass.

Bornstein, Diane D., (1977), "French Influence on Fifteenth-Century English Prose as Exemplified by the Translation of Christine de Pisan's Livre du Corps de Policie," Mediaeval Studies, 39, pp. 369-386.

Bornstein, Diane D., (1978), "Chaucer's Tale of Melibee as an example of the Style Clerigial," Chaucer Review, 12, pp. 236-254.

Bradbury, Malcolm and Fames McFarlane (eds.,) (1991), Modernism, Penguin Books, London.

Brady, Michael Emmett, (July, 1988), “J. M. Keynes' position on the General Applicability of Mathematical, Logical and Statistical Methods in Economics and Social Science," Synthese, Vol. 76, No. 1, pp. 1-24.

Brantlinger, Patrick, (1996), Fictions of State: Culture and Credit in Britain, 16941994, Ithaca, NY: Cornell University Press

Briggs, Asa, (1973), "Communications and Culture: 1823-1973: A Tale of Two Centuries," The Foundation Oration delivered at Birbeck College 1971, Birbeck College, London.

Broadberry, Stephen and Mark Harrison, (eds.), (2005), The Economics of World War 1, Cambridge University Press, Cambridge.

Page 377

8-Jun-11 
Bronfenbrenner, Martin, (May, 1967), "Marxian Influences in "Bourgeois" Economics," The American Economic Review, Vol. 57, No. 2, Papers and Proceedings of the Seventyninth Annual Meeting of the American Economic Association, pp. 624-635.

Brown, V., (1993), "Decanonizing Discourses: Textual Analysis and the History of Economic Thought," in Henderson. W., Dudley-Evans, T., and Backhouse, R., (eds.), Economics and Language, Routledge, London, pp. 64-84.

Brown, V., (1994a), "The Economy as Text," in Backhouse, R. E. (ed.), New Directions in Economic Methodology, Routledge, London, pp. 368-382.

Brown, William Adams Jr., (Mar. 1930), "German Reparations and the International Flow of Capital - Discussion," American Economic Review, Vol. 20, No. 1, Supplement, Papers and Proceedings of the Forty-second Annual Meeting of the American Economic Association, pp. 89-92.

Burnley, J. D., (July, 1986), "Curial Prose in England," Speculum, Vol. 61, No. 3.

Bushnell, C. J., (Sep., 1920), "The Economic Consequences of the Peace," The American Journal of Sociology, Vol. 26, No. 2., pp. 238-240.

Caldwell, B. J., (1994), Beyond Positivism: Economic Methodology in the Twentieth Century, Routledge, London.

Cannadine, David, (1992), G. M. Trevelyn: A Life in History, HarperCollins, London.

Carruthers, Bruce G., and Wendy Nelson Espeland, (July, 1991), "Accounting for Rationality: Double-Entry Bookkeeping and the Rhetoric of Economic Rationality," American Journal of Sociology, Vol. 97, No. 1, pp. 31-69.

Casson, M., (1997), Information and Organisation: A New Perspective on the Theory of the Firm, Oxford University Press, Oxford.

Cate, Tom, (April 1981), "Keynes on Monetary Theory and Policy: Comment," Southern Economic Journal, Vol. 47, No. 4, pp. 1132-1136.

Chandler, Alfred D., and James W. Cortada eds. (2000), A Nation Transformed by Information: How Information Has Shaped the United States from Colonial Times to the Present, Oxford University Press, New York.

Charle, C, (1994), La République des Universitaires, Seuil, Paris.

Checkland, S. G., (Feb., 1949), "The Propagation of Ricardian Economics in England," Economica, New Series, Vol. 16, No. 61, pp. 40-52.

Chiswick, B. R., and T. J. Hatton, (2003), "International Migration and the Integration of Labor Markets," in Globalisation in Historical Perspective, ed. M. D. Bordo, A. M. Taylor and J. G. Williamson, Chicago: University of Chicago Press. 
Churchill, Winston. 2007, The Aftermath, The Folio Society, London.

Clark, G., (1987), "Why Isn't the Whole World Developed? Lessons from the Cotton Mills," Journal of Economic History, 47, pp. 141-173.

Clarke, Peter, (2009), Keynes, Bloomsbury, London.

Clemens, M. A. and J. G. Williamson, (2004), "Wealth Bias in the First Global Capital Market Boom, 1870-1913," Economic Journal, 114, pp. 304-337.

Clout, Hugh, (1996), After the Ruins, University of Exeter Press, Devon.

Clower, Robert, (1973), "Snarks, Quarks, and Other Fictions," in L. P. Cain and P. J. Uselding (eds.), Business Enterprise and Economic Change, Kent University Press.

Coats, A. W., (1988), "Economic Rhetoric: The Social and Historical Context," in The Consequences of Economic Rhetoric, ed. A. Klamer, D. N. McCloskey and R. N. Solow, Cambridge University Press, Cambridge, pp. 64-84.

Coats, A. W. Bob, (1993), The Sociology and Professionalisation of Economics, Routledge, London.

Colander, David. C. and A. W. Coats, (eds.), (1989), The Spread of Economic Ideas, Cambridge University Press, Cambridge.

Collini, Stefan, Richard Whatmore, and John Burrow, (eds.,) (2000), Economy, Polity, and Society: British Intellectual History 1750-1950, Cambridge University Press, Cambridge.

Collini, Stefan, (2006), Absent Minds: Intellectuals in Britain, Oxford University Press, Oxford.

Collins, Bruce and Keith Robbins, (eds.), (1990), British Culture and Economic Decline, Cambridge University Press, Cambridge.

Connel, Philip, (2001), Romanticism, Economics and the Question of "Culture.", Oxford University Press, Oxford.

Cook, Eleanor, (Summer, 1979), "T. S. Eliot and the Carthaginian Peace," ELH, pp. 341-255.

Cook, Simon, (Winter 2008), "Poetry, Faith and Chivalry: Alfred Marshall's Response to Modern Socialism," History of Economics Review, No. 47, pp. 20-38.

Cowan, Robin and Dominique Foray, (1997), "The Economics of Codification and Diffusion of Knowledge." Industrial and Corporate Change, 6, no. 3 (Sept) , pp. 595-633.

Crabtree, D. and A. P. Thirwell (eds.), (1980), Keynes and the Bloomsbury Group, Macmillan, London. 
Craddock, Patricia, (May, 1988), “Historical Discovery and Literary Invention in Gibbon's "Decline and Fall"," Modern Philology, Vol. 85, No. 4 from Restoration to Revision: Essays in Honor of Gwin J. Kolb and Edward W. Rosenheim, The University of Chicago Press, Chicago, pp. 569-587.

Craig, Lee A. and Douglas Fisher, (1997), The Integration of the European Economy, 18501913, Macmillan Press, London.

Crémer, J., (1993), “Corporate Culture and Shared Knowledge," Industrial and Corporate Change, Vol. 2., pp. 351-86.

Cullen, Michael J., (1975), The Statistical Movement in Early Victorian Britain: The Foundations of Empirical Social Research, Barnes \& Nobel, New York.

Daudin, Guillaume, Matthias Morys and Kevin H. O’Rourke, (2008), “Globalization, 18701914," Department of Economics Discussion Paper Series, University of Oxford, Oxford.

Daudin, Guillaume, Matthias Morys and Kevin H. O’Rourke, (2010), “Gobalization, 18701914," in Stephen Broadberry and Kevin H. O'Rourke, (Eds.), (2010), The Cambridge Economic History of Modern Europe: Volume 2: 1870 to the Present, Cambridge University Press, Cambridge, pp. 5-29.

Davis, Earle, (1968), Vision Fugitive: Ezra Pound and Economics, The University of Kansas, Lawrence, U.S.A.

Davis, John B., "Economic Methodology since Kuhn," from Samuels, Warren J., Jeff E. Biddles, and John B. Davis, (eds.), (2003), A Companion to The History of Economic Thought, Blackwell Publishing, MA, USA.

Day, Clive, (Jun. 1920), "Keynes' Economic Consequences of the Peace," American Economic Review, Vol. 10, No. 2, pp. 299-312.

Dean, Sarah, (2010), "Human Fallibility in Thomas Hardy's "Convergence of the Twain" (April, 1912)." http://www.victorianweb.org/authors/hardy/dean1.html.

Delong, Brad, (2003), "Would Ezra Pound have been a better poet if he had taken Ec 10

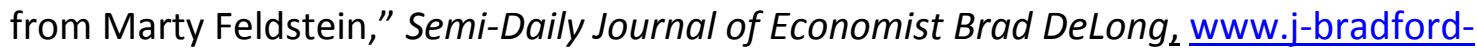
delong.net

Delong, Brad, (21 February 1996), "Monetary Reform," University of California, http://econ161.berkeley.edu/Econ Articles/Reviews/monetaryreform.html

DeWit, Andrew, (Oct. 2003), "Kaneko Masaru: A Public Intellectual Confronts Japan's Deep-rooted Economic Problems," Social Science Japan Journal, 6, 2, pp. 267-290.

Dillard, Dudley, (Winter, 1953), "Ricardo in Retrospect," Journal of Economic History, Vol. 13, No. 1, pp. 94-101. 
Djajic, Slobodan, Sajai Lahiri, and Pascalis Raimondos-Moller, (May, 1998), "The Transfer Problem and the Intertemporal Terms of Trade," Canadian Journal of Economics, Vol. 31, No. 2, pp. 427-436.

Dominik, William and Jon Hall (eds.), (2007), A Companion to Roman Rhetoric, Blackwell Publishing, Oxford, UK.

Eagleton, Terry, (2000), The Idea of Culture, Blackwell Publishers Inc., Oxford. (a)

Eagleton, Terry, (2000), "Base and Superstructure Revisited," New Literary History, 31, pp. 231-240. (b)

Easton, Lloyd D., (Dec., 1961), "Alienation and History in the Early Marx," Philosophy and Phenomenological Research, Vol. 22, No. 2, pp. 193-205.

Eatwell, John, Murray Milgate, and Peter Newman (eds.,) (1987), The New Palgrave: A Dictionary of Economics, Macmillan Press Limited, London.

Ekelund, Robert B. jr., and Robert Tollison, (May, 1976), "The New Political Economy of J. S. Mill: The Means to Social Justice," Canadian Journal of Economics, Vol. 9, No. 2, pp. 213231.

Eichengreen, Barry, (June 1984), "Reviewed Works: The Collected Writings of John Maynard Keynes. Vol. 19. Activities 1922-1929: The Return to Gold and Industrial Policy. Part I and II in Two Volumes," Journal of Economic Literature, Vol. 22, No. 2, pp. 586-588.

Eichengreen, Barry, (1998), "Transfer Problem," in Newman, Peter (ed.), The New Palgrave Dictionary of Economics and Law, Macmillan, London, pp. 684-685.

Eichengreen, Barry, (1992), Golden Fetters: The Gold standard and the Great Depression, 1919-1939, Oxford University Press, Oxford.

Eichengreen, Barry and Peter Temin, (June 1997), "The Gold standard and the Great Depression," NBER Working Paper Series, National Bureau of Economic Research, Cambridge, MA, pp. 1-43.

Eisenstein, Elizabeth, (1979), The Printing Press as an Agent of Change, Cambridge University Press, Cambridge.

Eloranta, Jari and Mark Harrison, (2010), "War and disintegration, 1914-1950,) in Stephen Broadberry and Kevin H. O'Rourke, (Eds.), (2010), The Cambridge Economic History of Modern Europe: Volume 2: 1870 to the Present, Cambridge University Press, Cambridge, pp. 134-155.

Eshag, E., (1963), From Marshall to Keynes: An Essay on the Monetary Theory of the Cambridge School, Oxford University Press, Oxford. 
Esteves, R. P., (2007), Between Imperialism and Capitalism. European Capital Exports Before 1914, Oxford University, Mimeo.

Falkus, M. E., (1975), “The German Business Cycle in the 1920's," Economic History Review, New Series, Vol. 28, No. 3, pp. 451-465.

Feather, J., (1994), Publishing, Piracy and Politics: An Historical Study of Copyright in Britain, Mansell, London.

Feather, John, (1988), A History of British Publishing, Croom Helm, New York.

Feiner, Susan F. and Barbara A. Morgan, (1985), "Discrimination: The Case of Economics Textbooks," Challenge, Nov-Dec., pp. 52-54.

Feis, H., (1930), Europe the World's Banker 1870-1914: An Account of European Foreign Investment and the Connection of World Finance with Diplomacy Before the War, Yale University Press, New Haven.

Feldman, Gerald D., (1992), Army, Industry and Labor in Germany, St. Martin's Press, New York.

Feldstein, M., and C. Horioka, (1980), "Domestic Saving and International Capital Flows," Economic Journal, 90., pp. 314-29.

Felix, David, (June, 1971), "Reparations Reconsidered with a Vengeance," Central European History, Vol. 4, No. 2, pp. 171-179.

Ferguson, N. (1996), "Constraints and room for manoeuvre in the German inflation of the early 1920s," Economic History Review, 46.

Ferguson, Niall, (1999), The Pity of War, Basic Books, London.

Ferguson, N., and M. Schularick, (2006), "The Empire Effect: The Determinants of Country Risk in the First Age of Globalisation, 1880-1913," Journal of Economic History, 66, pp. 283312.

Findlay, R. and K. H. O'Rourke, (2007), Power and Plenty, Trade, War, and the World Economy in the Second Millennium, Princeton: Princeton University Press.

Finkestein, Dr. David, (2010), "The Rise and Fall of the House of Blackwood's Magazine," http://www.qmu.ac.uk/mcs/mcc/Blackwoods/blackhist.html.

Fish, Stanley, (1995), Professional Correctness, Oxford University Press, Oxford.

Fitzgerald, F. Scott, Matthew J. Bruccoli, (ed.), (1992), The Great Gatsby, Macmillan, New York.

Fitzgibbons, A. (1988), Keynes' Vision, Clarendon Press, Oxford. 
Fischer, Claude S., (1992), America Calling: A Social History of the Telephone to 1940, University of California Press, Berkley.

Flandreau, M., and F. Zumer, (2004), The Making of Global Finance. 1880-1913, OECD, Paris.

Fodor, G., (1990), "From the Manchester Guardian Reconstruction Supplements to A Tract on Monetary Reform: The Early Development of Keynes' Thought," Contributions to Political Economy, 9, pp. 83-97.

Frandreau, M, and F. Zumer, (2004), "The Making of Global Finance: 1880-1914," OECD Development Center monograph, OECD, Paris.

Frank, Robert H., (Spring 2001), "The economist as public intellectual: A case for selling pareto improvements," Eastern Economic Journal, Vol. 27, Issue 2, pp. 221-226.

Frederico, Giovanni, (2010), “When did European markets integrate?" European Review of Economic History, pp. 1-34.

Frye, Northrop, (1990), Words with Power, Harcourt Brace Jovanovich, New York.

Furniss, H. Sanderson, (Mar. 1920), "The Peace Treaty and the Economic Chaos of Europe," Economic Journal, Vol. 30, No. 117, pp. 84-85.

Gagnier, Regenia, (1993), "On the Insatiability of Human Wants: Economic and Aesthetic Man," Victorian Studies, 36, pp. 125-153.

Galbraith, John Kenneth,(1961), The Great Crash, Houghton Mifflin, Boston, MA.

Gallagher, Catherine, (1985), The Industrial Reformation of English Fiction: Social Discourse and Narrative Form, 1832-1867, University of Chicago Press, Chicago.

Garnett, David, (1979), Great Friends: Portraits of Seventeen Writers, Macmillan, London.

Gerrard, B. (1991) “Keynes's General Theory: Interpreting the Interpretations," Economic Journal, 101, pp. 276-287.

Geweke, John, Joel Horowitz and Hashem Pesaran. "econometrics." The New Palgrave Dictionary of Economics. Second Edition. Eds. Steven N. Durlauf and Lawrence E. Blume. Palgrave Macmillan, 2008. The New Palgrave Dictionary of Economics Online. Palgrave Macmillan. 03 April 2011 <http://www.dictionaryofeconomics.com/article?id=pde2008_E000007> doi:10.1057/9780230226203.0425

Gibson-Graham, (1996), The End of Capitalism (As We Knew It), Blackwell, Oxford. Giddens, Anthony, (1990), The Consequences of Modernity, Stanford University Press, Stanford, CA. 
Gideonse, Harry D., (Dec. 1930), "Comment on Reparation Payments," The American Economic Review, Vol. 20, No. 4, pp. 691-695.

Ginzburg, Carlo, (c1999), History, rhetoric, and proof, University Press of New England, Hanover, NH.

Goldsworthy, Adrian, (2001), The Punic wars, Cassell Military, London.

Goodwin, C. D. and I. B. Holley, Jr. (eds.), (1968), The Transfer of Ideas, Duke University Press, Durham, NC.

Goriainov, Serge, (Jan., 1918), "The End of the Alliance of the Emperors," American Historical Review, Vol. 23, No. 2, pp. 324-349.

Goswiller, Richard, (1987), Revelation, Pacific Study Series, Melbourne.

Grabo, Carl, (1968), Prometheus Unbound; an interpretation, Gordian Press, New York.

Graves, Robert, (1981:1929), Goodbye to all that, Folio Society, London.

Groenewegen, Peter, (1995), A Soaring Eagle: Alfred Marshall 1842-1924, Edward Elgar, Aldershot.

Gudeman, Stephen, (Winter, 1984), “Ricardo's Representations," Representations, No. 5., pp. 92-114.

Habermas, Jürgen, Sara Lennox and Frank Lennox, (Autumn 1974), "The Public Sphere: An Encyclopedia Article," New German Critique, No. 3, pp. 49-55.

Halperin, Michael A., (Dec. 1946), "The Carthaginian Peace, or The Economic Consequences of Mr. Keynes," American Economic Review, Vol. 36, No. 5, pp. 930-934.

Handman, Max Sylvius, (June 1920), "The Peace," Southwestern Political Science Quarterly, University of Texas.

Hansen, Harry, (1949), "The Forgotten Men of Versailles," in Leighton, Isabel, The Aspirin Age, Simon and Schuster, New York.

Harrod, R. F., (1951), The Life of John Maynard Keynes, Macmillan \& Co. Ltd., London.

Hatton. T. J. and J. G. Williamson, (1998), The Age of Mass Migration: Causes and Economic Impact, Oxford University Press, Oxford.

Hatton, T. J. and J. G. Williamson, (2005), Global Migration and the World Economy: Two Centuries of Policy and Performance, Cambridge MA: MIT Press.

Hausman, D., (1992), The Inexact and Separate Science of Economics, Cambridge University Press, Cambridge, UK. 
Hawtrey, R. G., (June 1924), "Reviewed Work: A Tract on Monetary Reform. By J.M. Keynes," Economic Journal, Vol. 34, No. 134, pp. 227-235.

Hawtrey, R. G., (Aug. 1948), "The Carthaginian Peace, or The Economic Consequences of Mr. Keynes," Economica, Vol. 15, No. 59, pp. 234-238.

Headlam-Morley, James Wycliffe, (15 January, 1920), "The Economics of the Peace," Times Literary Supplement.

Headrick, Daniel, (2000), When Information Came of Age: Technologies of Knowledge in the Age of Reason and Revolution, 1700-1850, Oxford University Press, New York.

Heinzelman, K. (1980), The Economics of Imagination, University of Massachusetts Press, Amherst, Mass.

Henderson, W. (1982), "Metaphor in economics," Economics, Winter.

Henderson, Willie, (1995), Economics as Literature, Routledge, London.

Hession, C. H., (1983), John Maynard Keynes: A Personal Biography of the Man Who

Revolutionalised Capitalism and the Way We Live, Macmillan, London.

Hobson, J. A., (1902:1988), Imperialism, London: Unwin Hyman.

Hollander, Jacob H., (Apr., 1911), "The Work and Influence of Ricardo," American

Economic Review, Vol. 1, No.2, Papers and Discussions of the Twenty-third Annual Meeting, pp. 71-84.

Holroyd, Michael, (1991), Bernard Shaw: The Lure of Fantasy, Chatto \& Windus, London.

Holroyd, Michael, (1995), Lytton Strachey, Vintage, London.

Hoover, Kenneth R., (Spring 2005), "Economics as Ideology: Keynes, Laski, Hayek, and the Creation of Contemporary Politics," Journal of Markets \& Morality, Volume 8, Number 1, pp. 1-3.

Houck, Davis W., (1999), "Rhetoric, Science, and Economic Prophecy: John Maynard Keynes' correspondence with Franklin D. Roosevelt," in Woodmansee, Martha and Mark Osteen, The New Economic Criticism, Routledge, New York, pp. 334-364.

Hubbard, R. Glenn, (Fall 2004), "The Economist as Public Intellectual," Journal of Economic Education, Vol. 35, Issue 4, pp. 391-395.

Hudson, Heather E., (1998), "Global Information Infrastructure: Eliminating the Distance Barrier," Business Economics, 33, No. 2 (April), pp. 25-31.

Hull, Charles H., (May, 1900), "Petty's Place in the History of Economic Theory," Quarterly Journal of Economics, Vol. 14, No. 3, pp. 307-34. 
Hunsberger, George E., (Jan. 1957), "Reviewed Works: Memorials of Alfred Marshall by A. C. Pigou," Southern Economic Journal, Vol. 23, No. 3, pp. 332-333.

Irvine, William, (May, 1946), "George Bernard Shaw and Karl Marx," Journal of Economic History, Vol. 6, No. 1, pp. 53-72.

Jacks, D. S., (2006), "What Drove $19^{\text {th }}$ Century Commodity Market Integration?" Explorations in Economic History, 43, pp. 383-412.

Jacoby, Russell, (2000 (a)), The Last Intellectuals, Basic Books, New York. Jacoby, Russell, (2000 (b)), "Intellectuals and their discontents," The Hedehog Review, Fall. Jennings, Jeremy and Anthony Kemp-Welch, (eds.), (2003), Intellectuals in Politics: From the Dreyfus Affair to Salman Rushdie, Taylor \& Francis e-Library, Routledge, New York. Johns, Adrian, (1998), The Nature of the Book: Print and Knowledge in the Making, University of Chicago Press, Chicago.

Johnson, Elizabeth, (Jan. - Feb. 1974), “John Maynard Keynes: Scientist or Politician?” Journal of Political Economy, Vol. 82, No. 1, pp. 99-111.

Johnson, George M., (Summer, 1994), "'The Spirit of the Age": Virginia Woolf's Response to Second Wave Psychology," Twentieth Century Literature, Vol. 40, No. 2, pp. 139-164.

Johnson, Harry G., (Feb. 1975), "The Classical Transfer Problem: An Alternative Formulation," Economica, Vol. 42, No. 165, pp. 20-31.

Johnson, Paul, (1990), Intellectuals, HarperPerennial, New York.

Jones, Eric, (1995), “Culture and Its Relationship to Economic Change," Journal of Institutional and Theoretical Economics, 151, No. 2 (June), pp. 269-285.

Jones, Eric L., (2006), Cultures Merging, Princeton University Press, Princeton and Oxford. Kaldor, Mary, (1999), New and old wars: organised violence in the global era., Polity Press, Cambridge.

Kaufmann, David, (1995), The Business of Common Life, The John Hopkins University Press, Baltimore.

Keegan, John, (1998), The First World War, Hutchinson, London.

Kelly, Christopher, (Apr., 1997), "A Grand Tour: Reading Gibbon's 'Decline and Fall'," Greece \& Rome, Second Series, Vol. 44, No. 1, pp. 39-58.

Kenny, Anthony, (1986), "Evolution of a Primate," Oxford Magazine, Sixth Week, Hilary Term.

Kennedy, Paul, (1989), The Rise and Fall of the Great Powers, Fontana Press. 
Kent, Bruce, (1989), The Spoils of War, Clarendon Press, Oxford.

Kenwood, George A. and Alan L. Lougheed, (1971), The Growth of the International Economy 1820-1960, George Allen \& Unwin, London.

Keynes, John Maynard, (1971) Edited by Donald Moggridge, The Collected Writings of John Maynard Keynes: II, The Economic Consequences of the Peace, Macmillan and Co. Ltd., London.

Keynes, John Maynard, (1971) Edited by Donald Moggridge, The Collected Writings of John Maynard Keynes: IV, A Tract on Monetary Reform, Macmillan and Co. Ltd., London.

Keynes, John Maynard, (1971) Edited by Donald Moggridge, The Collected Writings of John Maynard Keynes: VI, A Treatise on Money, 2 The Applied Theory of Money, Macmillan and Co. Ltd., London.

Keynes, John Maynard, (1973), Edited by Donald Moggridge, The Collected Writings of John Maynard Keynes: VIII, A Treatise on Probability, Macmillan and Co. Ltd., London.

Keynes, John Maynard, (1972) Edited by Donald Moggridge, The Collected Writings of John Maynard Keynes: IX, Essays in Persuasion, Macmillan and Co. Ltd., London.

Keynes, John Maynard, (1971) Edited by Donald Moggridge, The Collected Writings of John Maynard Keynes: $X$, Essays in Biography, Macmillan and Co. Ltd., London.

Keynes, John Maynard, (1971) Edited by Donald Moggridge, The Collected Writings of John Maynard Keynes: XVI Activities 1914-1919 The Treasury \& Versailles, Macmillan and Co. Ltd., London.

Keynes, John Maynard, (1977) Edited by Donald Moggridge, The Collected Writings of John Maynard Keynes: XVII Activities 1920-1922 Treaty Revision and Reconstruction, Macmillan and Co. Ltd., London.

Keynes, John Maynard, (1981) Edited by Donald Moggridge, The Collected Writings of John Maynard Keynes: XIX Activities 1922-1929 The Return to Gold and Industrial Policy in Two Volumes Part I and Part II, Macmillan and Co. Ltd., London.

Keynes, John Maynard, (1982), Edited by Donald Moggridge, The Collected Writings of John Maynard Keynes: XXI Activities 1931-9: World Crisis and Policies in Britain and America, Macmillan and Co. Ltd., London.

Keynes, John Maynard, (1919), The Economic Consequences of the Peace, Macmillan and Co., Limited, London.

Keynes, John Maynard, (1922), A Revision of the Treaty: Being a Sequel to The Economic Consequences of the Peace, Harcourt, Brace and Company, New York. 
Keynes, J. M., (Mar. 1929), "The German Transfer Problem," Economic Journal, Vol. 39, No. 153, pp. 1-7.

Keynes, J. M., (Jun. 1929), "The Reparation Problem: A Discussion,” Economic Journal, Vol. 39, No. 154, pp. 172-182.

Keynes, John Maynard, (1936), The General Theory of Unemployment, Interest and Money, Macmillan, London.

Keynes, John Maynard, (Sep. 1924), “Alfred Marshall, 1842-1924," Economic Journal, Vol. 34, No. 135, pp. 311-372.

Keynes, John Maynard, (1940), How to Pay for the War, Macmillan and Co., Limited, London.

Keynes, John Maynard, (1949), Two Memoirs, Rupert Hart-Davis, London.

King, Clyde L., (July, 1920), "The Economic Consequences of the Peace," Annals of the American Academy of Political and Social Science, Vol. 90., Industrial Stability, p. 173.

Klamer, Arjo, ed., (1996), The Value of Culture: On the Relationship Between Economics and Arts, Amsterdam University Press, Amsterdam.

Klamer, Arjo, Donald [Deirdre] N. McCloskey, and Robert M. Solow, eds., (1988), The Consequences of Economic Rhetoric, Cambridge University Press, Cambridge.

Klamer, Arjo, (1987), "As If Economists and Their Subjects Were Rational," in The Rhetoric of Human Sciences, eds., John S. Nelson, Allan Megill, and Donald N. McCloskey, University of Wisconsin Press, Madison, pp. 163-183.

Klapper, Joseph, (1960), The Effects of Mass Communication, Free Press, Glencoe, IL.

Klaver, Claudia C., (2003), A/Moral Economics, The Ohio State University Press, Columbus.

Klovland, J. T., (2005), "Commodity market integration 1850-1913: evidence from Britain and Germany," European Review of Economic History, 9, pp. 163-97.

Knafo, Samuel, (Feb., 2006), "The Gold standard and the Origins of the Modern International Monetary System," Review of International Political Economy, Vol. 13, No. 1, pp. 78-102.

Komlos, J. (1983), The Habsburg monarchy as a customs union, Princeton: Princeton University Press.

Krasno, Jean E. (2004), The United Nations: confronting the challenges of a global society, Lynne Rienner Publishers, London. 
Laidler, D., (1999), Fabricating the Keynesian Revolution: Studies of the Inter-war Literature on Money, the Cycle and Unemployment, Cambridge University Press, Cambridge.

Lee, Hermoine, (1997), Virginia Woolf, Vintage, London.

Leith-Ross, Sir Frederick, (1968), Money Talks, Hutchinson, London.

Lentin, A. (1984), Lloyd George, Woodrow Wilson and the Guilt of Germany: An Essay in the Pre-History of Appeasement, Leicester University Press, Leicester.

Levitt, Theodore, (Aug. 1976), “Alfred Marshall: Victorian Relevance for Modern Economics," Quarterly Journal of Economics, Vol. 90, No. 3, pp. 425-443.

Levy, Leonard W., (1985), Emergence of the Free Press, Oxford University Press, New York. Levy, Paul, (ed.), (2005), The Letters of Lytton Strachey, Viking, London.

Lloyd George, David, (1932), The Truth About Reparations and War-Debts, Doubleday, Garden City, New York.

Machlup, F., (1964), International Payments, Debts and Gold, Scribner, New York.

Machlup, F., (1976), International Payments, Debts and Gold, New York University Press, New York.

Machlup, Fritz, (1980-84), Knowledge: Its Creation, Distribution and Economic Significance, 3 Vols., Princeton University Press, Princeton, NJ.

Mackintosh, W. A., (Aug. 1947), "Keynes as a Public Servant," Canadian Journal of Economic and Political Science, Vol. 13, No. 3., pp. 379-383.

Macmillan, Margaret, (2001), Peacemakers, London: John Murray.

Macrosty, Henry W., (Mar. 1935), "The Consequences of the War to Great Britain," Economic Journal, Vol. 45, No. 177, pp. 162-164.

Maddison, A., (1995), Monitoring the world economy 1820-1992, OECD, Paris.

Maddison, A., (2001), The World Economy: A Millennial Perspective, OECD, Paris.

Maddison, A., (2007), Contours of the World Economy, 1-2030AD: Essays in MacroEconomic History, Oxford University Press, Oxford.

Maier, C. S. (1975), Recasting bourgeois Europe: stabilisation in France, Germany, and Italy in the decade after World War 1, Princeton University Press, Princeton.

Maizels, A. (1964), Industrial Growth and World Trade, Cambridge University Press, Cambridge. 
Mantoux, Étienne, (1946), The Carthaginian Peace - or The Economic Consequences of Mr. Keynes, Oxford University Press, London.

Marks, Sally, (1978), "The Myths of Reparation," Central European History, Vol. 11, No. 3, pp. 231-255.

Markwell, Donald, (2006), John Maynard Keynes and International Relations, Oxford University Press, Oxford.

Marshall, Alfred, (1961), Principles of Economics, $9^{\text {th }}$ Edition, Volume 1, Macmillan and Co. Limited, London.

Marzola, A. (1994), "Rhetoric and Imagination in the Economic and Political Writings of J. M. Keynes," in John Maynard Keynes: Language and Methods, Edward Elgar, Aldershot.

Mauro, P., N. Sussman and Y. Yafeh, (2002), "Emerging Market Spreads: Then Versus Now," Quarterly Journal of Economics, 117, pp. 695-733.

May, Derwent, (2001), Critical Times: The History of The Times Literary Supplement, HarperCollinsPublishers, London.

May, Lary, (1980), Screening Out the Past: The Birth of Mass Culture and the Motion Picture Industry, Oxford University Press, New York.

McClelland, Peter D., (1975), Causal Explanation and Model Building in History, Economics, and the New Economic History, Cornell University Press, Cornell.

McCloskey, Donald N., (1986), The Rhetoric of Economics, Wheatsheaf Books Ltd., Sussex. McCloskey, D., (1994), "How to Do a Rhetorical Analysis and Why?” in Backhouse, R. (ed.), New Directions in Economic Methodology, Routledge, London, pp. 319-342.

McCloskey, D. N. (1991), "Mere style in economic journals, 1920 to the present," Economic Notes, 20 (1), pp. 135-158.

McCloskey, D. N. (2006), The Bourgeois Virtues: Ethics for an Age of Commerce, Universuty of Chicago Press, Chicago.

McCloskey, D. N. (2010), The Bourgeois Dignity: Why Economics Can't Explain the Modern World, Universuty of Chicago Press, Chicago.

McDonald, Patrick J. and Kevin Sweeney, (April 2007), "The Achilles' Heel of Liberal IR Theory? Globalisation and Conflict in the Pre-World War 1 Era," World Politics, 59, pp. 370-403.

McFadyean, Andrew, (March 1932), "Review of Essays in Persuasion," International Affairs, Volume 11, No. 2, p. 258. 
McHenry, Robert, (ed.,) (1992), The New Encyclopaedia Britannica, The University of Chicago, Chicago

McIntosh, Douglas C., (Dec. 1977), "Mantoux Versus Keynes: A Note on German and the Reparations Controversy," Economic Journal, Vol. 87, No. 348, pp. 765-767.

Meltzler, Lloyd A., (Jun. 1942), "The Transfer Problem Reconsidered," Journal of Political Economy, Vol. 50, No. 3, pp. 397-414.

Menard, C. Winter, (1980), "Three Forms of Resistance to Statistics: Say, Cournot, Walras," History of Political Economy, 12 (4), pp. 524-541.

Menninger, Karl, (1969), Number Words and Number Symbols: A Cultural History of Numbers, MIT Press, Cambridge, MA.

Meyers, Jeffrey, (1987), Homosexuality and Literature, Athlone Press, London.

Middelton, Roger, (1998), Charlatans or Saviours? Economists and the British economy from Marshall to Meade, Edward Elgar, Cheltenham, UK.

Mini, P. V. (1991), Keynes, Bloomsbury and the General Theory, Macmillan, London.

Mitchener, K. J. and M. Weidenmier, (2007), Trade and Empire, Mimeo, Santa Clara University and Claremont McKenna College.

Moggridge, D. E. and Susan Howson, (July 1974), "Keynes on Monetary Policy, 19101946," Oxford Economic Papers, Mew Series, Vol. 26, No. 2, pp. 226-247.

Moggridge, D. E., (1992), Maynard Keynes: An Economist's Biography, Routledge, London. Morishima, Michio, (1982), Why Has Japan "Succeeded"? Western Technology and the Japanese Ethos, Cambridge University Press, Cambridge.

Mokyr, Joel, (2002), The Gifts of Athena, Princeton University Press, Princeton.

Mokyr, Joel, (2010), The Enlightened Economy: An Economic History of Britain, Princeton University Press, Princeton.

Morkot, Robert, (1996), The Penguin Historical Atlas of Ancient Greece, Penguin Books, London.

Moser, Charles, (1992), Encyclopedia of Russian Literature, Cambridge University Press, Cambridge.

Mott, Frank Luther, (1947), Golden Multitudes: The Story of Best Sellers in the United States, Macmillan, New York.

Murray, Joddy, (2009), Non-Discursive Rhetoric, Suny Press, New York. 
Nayar, Baldev Raj, (2003), "Economic Globalisation and Its Advance: From Shallow to Deep Integration," Economic and Political Weekly, Vol. 38, No. 45, pp. 4776-4782.

Neilson, Francis, (Oct., 1948), "The Twilight of Marx," American Journal of Economics and Sociology, Vol. 8, No. 1, pp. 1-16.

Nicolson, Harold, (1945), Peacemaking 1919, Constable \& Co. Ltd., London.

North, D. C., (1990), Institutions, Institutional Change, and Economic Performance, Cambridge University Press, Cambridge.

Obstfeld, M., and A. M. Taylor, (2004), Global Capital Markets: Integration, Crisis, and Growth, Cambridge: Cambridge University Press.

O’Donnell, R. M., (1989), Keynes: Philosophy, Economics \& Politics, Macmillan Press Ltd., London.

Ohlin, Bertil, (June, 1929), "1: Transfer Difficulties Real and Imagined," in Keynes, J. M., "The Reparation Problem: A Discussion," Economic Journal, XXXIX, pp. 172-182.

Ohlin, Bertil, (June 1932), "Review: Essays in Persuasion," Economic Journal, Vol. 42, No. 166, pp. 258-262.

O’Riordan, Tomás, (2010), “Emancipation, Famine and Religion: Ireland under the Union, 1815-1870: Asenath Nicholson," University of College Cork, Ireland, http://multitext.ucc.ie/d/Asenath_Nicholson.

O'Rourke, K. H. and J. G. Williamson, (1994), "Late $19^{\text {th }}$ Century Anglo-American Factor Price Convergence: Were Heckscher and Ohlin Right?, Journal of Economic History, 54: pp. 892-916.

O’Rourke, K. H. and J. G. Williamson, (1999), Globalisation and History: The Evolution of a Nineteenth Century Atlantic Economy, MIT Press, Cambridge MA..

Owens, Richard N., (December 1924), "Reviewed Works: A Tract on Monetary Reform," The Journal of Political Economy, Vol. 32, No. 6, pp. 730-731.

Oxford Dictionary of National Biography, Oxford University Press, 2004; online edn, Jan 2008 [http://www.oxforddnb.com/view/article

- 34489, Middleton, Roger, 'Ross, Sir Frederick William Leith - (1887-1968)

- 33585, Oxbury, H. F., 'Sir Percy James Grigg - (1890-1964)

- 32629, Williamson, Philip, 'Cripps, Charles Alfred, first Baron Parmoor - (1852-1941)

- 35928, Wasserstein, Bernard, 'Samuel, Herbert Louis, first Viscount Samuel - (1870-

1963)

- 35769, Tracey, H. T., 'Roberts, George Henry - (1868-1928)

- 30705, Hale, Leslie, 'Benn, William Wedgewood, first Viscount Stansgate - (1877-1960)

- 31202, Blake, Robert, 'Harmsworth, Esmond Cecil, second Viscount Rothermere - (18981978)

Page 392

8-Jun-11 
- 35159, Stray, Christopher, 'Murray (George) Gilbert Aimé - (1866-1957)

- 36984, Porter, Dilwyn, 'Hartley Withers' - (1867-1950)

- 34310, Cairncross, Alec, 'John Maynard Keynes, Baron Keynes' - (1883-1946)

- 30472, Green, E. H. H., 'Ashley, Sir William James' - (1860-1927)

- 36831, Parrinder, Patrick, 'Wells, Herbert George' - (1866-1946)

- 33360, Grieves, Keith, 'Sir Eric Geddes' - (1875-1937)

- 36736, Sutherland, John, 'Ward, Mary Augusta' - (1851-1920)

- 31477, Skidelsky, Robert, 'Mosley, Sir Oswald Ernald' - (1896-1980)

- 36337, Newman, Michael, 'Strachey, (Evelyn) John St Loe' - (1901-1963)

- 32413, Addison, Paul, 'Churchill, Sir Winston Leonard Spencer' - (1874-1965)

- 33991, Williamson, Philip, 'Horne, Robert Stevenson' - (1871-1940)

- 31212, Black, R. D. Collison, 'Hawtrey, Sir Ralph George - (1879-1975)

- 35776, Fletcher, Gordon, 'Robertson, Sir Dennis Holme - (1890-1963)

- 33785, Goldstein, Erik, 'Morley, Sir James Wycliffe Headlam-' - (1863-1929)

Park, Robert E., (1940), "News as a Form of Knowledge," American Journal of Sociology, 45, pp. 675-677.

Parker, William N., (Jun. 1954), "The Carthaginian Peace, or The Economic Consequences of Mr. Keynes," The Journal of Political Economy, Vol. 62, No. 3, pp. 272-273.

Parsons, Howard L., (January, 1964), "The Prophetic Mission of Karl Marx," Journal of Religion, Vol. 44, No. 1, pp. 52-72.

Patinkin, Don, (June 1975), "The Collected Writings of John Maynard Keynes: From the Tract to the General Theory," Economic Journal, Vol. 85, No. 338, pp. 249-271.

Patinkin, Don, (Nov., 1976), "Keynes and Econometrics: On the Interaction between the Macroeconomic Revolutions of the Interwar Period," Econometrica, Vol. 44, No. 6, pp. 1091-1123.

Payli, Melchior, (July, 1947), "Review of The Carthaginian Peace," Review of Politics, Vol. 9, No. 3, pp. 390-393.

Peach, Terry. "Ricardo, David (1772-1823)." The New Palgrave Dictionary of Economics. Second Edition. Eds. Steven N. Durlauf and Lawrence E. Blume. Palgrave Macmillan, 2008. The New Palgrave Dictionary of Economics Online. Palgrave Macmillan. 03 April 2011 <http://www.dictionaryofeconomics.com/article?id=pde2008_R000259> doi:10.1057/9780230226203.1439

Peden, G. C., (2000), The Treasury and British Public Policy: 1906-1959, Oxford University Press, Oxford.

Pettitt, Clare, (2004), Patent Inventions: Intellectual Property and the Victorian Novel, Oxford University Press, Oxford. 
Phelps, Michael G., (Summer, 1980), "Laments, Ancient and Modern: Keynes on Mathematical and Econometric Methodology," Journal of Post Keynesian Economics, Vol. 2, No. 4, pp. 482-493.

Phelps Brown, E. H. and Browne, M. (1967), A Century of Pay, Macmillan, London.

Plant, Marjorie, (1974), The English Book Trade: An Economic History of the Making and Sale of Books, $3^{\text {rd }}$ edition, Allen \& Unwin, London.

Politzer, Robert L., (Oct-Dec., 1961), "Synonymic Repetition in Late Latin and Romance," Language, Vol. 37, No. 4.

Pollard, Sidney, (1973), The Development of the British Economy, 1914-1980, Edward Arnold, Caulfield East.

Posner, Richard A., (2003), Public Intellectuals: A Study of Decline, Harvard University Press, Harvard.

Preminger, Alex (ed.), (1974), Princeton Encyclopedia of Poetry and Poetics, Princeton, New Jersey.

Price, L. L., (Jun., 1893), "Adam Smith and his Relations to Recent Economics," The Economic Journal, Vol. 3, No. 10, pp. 239-254.

Ramsden, John, (ed.), (2005), The Oxford Companion to Twentieth Century British Politics, Oxford University Press, Oxford.

Reeve, C. D. C., (c1988), Philosopher-kings: the argument of Plato's Republic, Princeton University Press, Princeton, N. J.

Reynolds, W. Vaughan, (April, 1935), "The Reception of Johnson's Prose Style," Review of English Studies, Vol. 11, No. 42.

Ritschl, Albrecht, (2005), "The pity of peace: Germany's economy at war, 1914-1918 and beyond," in Bradberry, Stephen and Mark Harrison (eds.), (2005), The Economics of World War 1, Cambridge: Cambridge University Press.

Robb, George, (2002), British Culture and the First World War, Palgrave, Hampshire, New York.

Roberts, Priscilla, (2010), "Benjamin Strong, the Federal Reserve, and the limits to interwar American nationalism: Part I: Intellectual profile of a central banker," http://www.allbusiness.com/finance/940014-1.html

Robertson, D. H., (March, 1920), "The Economic Consequences of the Peace," Economic Journal, Vol. 30., No. 117, pp. 77-84.

Robertson, D. H., (Mar. 1922), "A Revision of the Treaty, being a Sequel to the Economic Consequences of the Peace," Economic Journal, Vol. 32, No. 125, pp. 77-78.

Page 394

8-Jun-11 
Ronnback, K., (2009), "Integartion of global commodity markets in the early modern era," European Review of Economic History, 13, pp. 95-120.

Rosenberg, Alexander, (1988), "Economics is Too Important to Be Left to the Rhetoricians," Economics and Philosophy,_4, pp. 110-128.

Rosenbaum, S. P., (1975), The Bloomsbury Group, University of Toronto Press, Toronto and Buffalo.

Rosenbaum, S. P., (1981), "Preface to a Literary History of the Bloomsbury Group," New Literary History, Vol. 12, No. 2., (Winter), pp. 329-344.

Rosenbaum, S. P., (1983), "Virginia Woolf and the Intellectual Origins of Bloomsbury," Virginia Woolf: Centennial Essays, eds. Elaine K. Ginsburg and Laura Moss Gottlieb, Whitson, Troy, NY.

Rothbard, Murray N., (October 09, 2009), "Karl Marx as Religious Eschatologist," http://mises.org/daily/3769.

Rouse, Robert, (March 15, 2006), "Happy Anniversary to the first scheduled presidential press conference - 93 years young!" http://www.americanchronicle.com/articles/6883.

Samuelson, Paul A., (Jun. 1952), "The Transfer Problem and Transfer Costs: The Terms of Trade When Impediments are Absent," Economic Journal, Vol. 62, No. 246, pp. 278-304.

Sayers, R. S., (Jun. 1972), “The Young Keynes," Economic Journal, Vol. 82, No. 326, pp. 591599.

Schabas, Margaret, (Mar. 1989), "Alfred Marshall, W. Stanley Jevon, and the Mathematization of Economics," Isis, Vol. 80, No. 1, pp. 60-73.

Schuker, Stephen A., (1988), American "reparations" to Germany, 1919-33: Implications for the Third-World debt crisis, International Finance Section, Dept. of Economics, Princeton University Press, Princeton, NJ.

Schumpeter, Joseph A., (Jun. 1941), "Alfred Marshall's Principles: A Semi-Centennial Appraisal," American Economic Review, Vol. 31, No. 2, pp. 236-248.

Schumpeter, Joseph A., (September, 1946), “John Maynard Keynes 1883-1946," American Economic Review, XXXVI.

Schwartz, Pedro, (1968), The New Political Economy of J. S. Mill, Weidenfeld and Nicolson, London.

Scott, W. R., (Sep., 1936), "New Light on Adam Smith," Economic Journal, Vol. 46, No. 183, pp. 401-411.

Shell, Marc, (1993), Money, Language, and Thought, The John Hopkins University Press, Baltimore.

Page 395

8-Jun-11 
Silkin, (1996), Penguin Book of First World War Poetry, Penguin Books Ltd., London.

Singleton, John, (2007), "'Destruction ... and misery': the First World War," Oliver, Michael J. and Derek H. Aldcroft (eds.), Economic Disasters of the Twentieth Century, Edward Elgar, Cheltenham, UK, pp. 9-50.

Skidelsky, Robert, (1979), "Keynes and the Reconstruction of Liberalism," Encounter, 52, pp. 29-39.

Skidelsky, Robert, (1983), John Maynard Keynes: Hopes Betrayed 1883-1920, Macmillan, London.

Skidelsky, Robert, (1992 (a)), John Maynard Keynes: The Economist as Saviour, 1920-1937, Macmillan, London.

Skidelsky, Robert, (1992 (b)), "Reviewed Work: Keynes, Bloomsbury and the General Theory, by Mini (Piero V.)," Economic Journal, Vol. 102, No. 414, pp. 1269-1272.

Skinner, Andrew. "Smith, Adam (1723-1790)." The New Palgrave Dictionary of Economics. Second Edition. Eds. Steven N. Durlauf and Lawrence E. Blume. Palgrave Macmillan, 2008. The New Palgrave Dictionary of Economics Online. Palgrave Macmillan. 03 April 2011 <http://www.dictionaryofeconomics.com/article?id=pde2008_S000154> doi:10.1057/9780230226203.1545

Smithies, Arthur, (Aug. 1972), "Keynes Revisited," Quarterly Journal of Economics, Vol. 86, No. 3, pp. 463-475.

Snow, C. P., (1998), The Two Cultures, Cambridge University Press, Cambridge.

Snowden, Brian, and Howard R. Vane, (1997), Reflections on the Development of Modern Macroeconomics, Edward Elgar, Cheltenham, UK.

Solow, Robert, (1989), "How economic ideas turn to mush," in Colander, David C. and A. W. Coats (eds.), The Spread of Economic Ideas, Cambridge University Press, Cambridge, pp. 75-84.

Sommerville, C. John, (1996), The News Revolution in England: Cultural Dynamics of Daily Information, Oxford University Press, New York.

Sontag, Susan, (1964), “Notes on “Camp”," Partisan Review, 31, pp. 515-530.

Soules, Marshall, (2 September, 2007), "Jürgen Habermas and the Public Sphere," http//www.mala.bc.ca/-Soules/media301/habermas.htm.

Sowell, Thomas, (2008), "Say's Law," The New Palgrave Dictionary of Economics, Second Edition. Eds. Steven N. Durlauf and Lawrence E. Blume. Palgrave Macmillan, The New Palgrave Dictionary of Economics Online, Palgrave Macmillan, 24 April 2011. 
http://www.dictionaryofeconomics.com/article?id=pde2008_S000028>doi:10.1057/9780 230226203.1478

Spengler, J. A., (1970), "Notes on the international transmission of economic ideas," History of Political Economy, 2(1), pp. 133-151.

Spurr, Barry, (1995), A Literary-Critical Analysis of the Complete Prose Works of Lytton Strachey (1880-1932), The Edwin Mellen Press, New York.

Spurr, Barry, 1990), "Camp Mandarin: The Prose Style of Lytton Strachey," English Literature in Transition (1880-1920), 33:1, pp. 31-45.

Sterling, Christopher H., (1984), Electronic Media: A Guide to Trends in Broadcasting and Newer Technologies, 1920-1983, Praeger, New York.

Stephens, Michael, (1988), A History of News, Viking, New York.

Stevens, Michael R., (Fall 1999), "T.S. Eliot's Neo-Medieval Economics," Journal of Markets and Morality, http://www.acton.org/publicat/m and m/1999 fall/stevens.html

Stone, I., (1999), The Global Export of Capital from Great Britain, 1865-1914: A Statistical Survey, Macmillan Press, London.

Strachey, Lytton, (1986), Eminent Victorians, The Folio Society, London.

Strachey, Lytton, (1948), Landmarks in French Literature, Chatto and Windus, London.

Strachey, Lytton, (1980), “Creighton” (1929), The Shorter Strachey, Michael Holroyd and Paul Levy, eds., Oxford University Press, New York.

Strachey, Lytton, (1933), "English Letter Writers," Characters and Commentaries, Chatto and Windus, London.

Strachey, Lytton, (1921), Queen Victoria, Penguin, Hammersmith.

Susman, Warren, (1984), Culture as History: The Transformation of American Society in the Twentieth Century, Pantheon, New York.

Sutherland, J. A., (1976), Victorian Novelists and Publishers, Athlone Press, London.

Svennilson, Michael, (1954), Growth and Stagnation in the European Economy, United Nations, Geneva.

Taddeo, Julie Anne, (1997), "Plato's Apostles: Edwardian Cambridge and the "New Style of Love."', Journal of the History of Sexuality, Volume 8, Issue 2, pp. 196-228.

Taddeo, Julie Anne, (2002), Lytton Strachey and the Search for Modern Sexual Identity, The Harrington Press Inc., New York. 
Taussig, F. W., (Feb., 1920), “Keynes, The Economic Consequences of the Peace,' Quarterly Journal of Economics, Vol. 34, No. 2., pp. 381-387.

Taylor, A. J. P., (1975), English History: 1914-1945, Oxford University Press, Oxford.

Thatcher, David, (1970), Nietzsche in England, 1890-1940: the growth of a reputation, University of Toronto Press, Toronto.

Thompson, James, (1996), Models of Value: Eighteenth-Century Political Economy and the Novel, Duke University Press, Durham, NC.

Trachtenberg, Marc, (March, 1979), "Reparation at the Paris Peace Conference," The Journal of Modern History, The University of Chicago Press, Vol., 51, No. 1, pp. 24-55.

Trachtenberg, Marc, (1980), Reparations in World Politics: France and European Economic Diplomacy, 1916-1923, Columbia University Press, New York.

Veblen, Thorstein, (1919), "Why Economics is Not an Evolutionary Science," The Pace of Science in Modern Civilisation, Huebsch, New York, pp. 65-89.

Ville, S., (1991), "Shipping Industry Technologies," in International Technology Transfer: Europe, Japan and the USA, 1700-1914, ed. D. J. Jeremy. Aldershot: Edward Elgar.

Vos, Alvin, (July, 1974), "The Formation of Roger Ascham's Prose Style," Studies in Philology, Vol. 71, No. 3.

Waller, William, and Linda Robertson, (1990), “Why Johnny (PhD, Economics) Can't Read: A Rhetorical Analysis of Thorstein Veblen and a Response to Donald McCloskey's Rhetoric of Economics," Journal of Economic Issues, 24 (December), pp. 1027-1044.

Watts, Cedric, (1990), Literature and Money: Financial Myth and Literary Truth, Harvester Wheatsheaf, New York and London.

Weill-Raynal, Etienne, (1938), Les Réparations Allemands et la France, Paris.

Whitaker, John K., (ed.), (1990), Centenary Essays on Alfred Marshall, Cambridge University Press, Cambridge.

Williams, John H., (Mar. 1930), "Reparations and the Flow of Capital," The American Economic Review, Vol. 20, No. 1 Supplement, Papers and Proceeding of the Forty-Second Annual Meeting of the American Economic Association, pp. 73-79.

Williams, Raymond, (1958), Culture and Society, Chatto \& Windus, London.

Williamson, Jeffrey G., (1996), "Globalisation, Convergence, and History," The Journal of Economic History, Vol. 56, No. 2, pp. 277-306. 
Williamson, Jeffrey G., (2008), "Globalization and the Great Divergence: terms of trade booms, volatility and the poor periphery, 1782-1913," European Review of Economic History, 12, pp. 355-391.

Wilson, A. N., (2003), The Victorians, W. W. Norton \& Company, New York.

Wilson, A. N., (2005), After The Victorians: 1901-1953, Hutchinson, London.

Winch, Donald, (1996), Riches and Poverty: An Intellectual History of Political Economy in Britain, 1750-1834, Cambridge University Press, Cambridge.

W.L.H., (October 1932), "Review: Essays in Persuasion," Pacific Affairs, Volume 5, No. 10, pp. 905-906.

Wolcott, Susan, (Sep., 1993), "Keynes Versus Churchill: Revaluation and British Unemployment in the 1920s," Journal of Economic History, Vol. 53, No. 3, pp. 601-628.

Wordsworth, William; edited by Sally Bushell, James A. Butler, and Michael C. Jaye; with the assistance of David Garcia, (2007) The excursion, Cornell University Press, Ithaca.

Worthington, lan, (ed.), (2007), A Companion to Greek Rhetoric, Blackwell Publishing, Oxford (UK).

Yeo, Richard R., (1986), "Scientific Method and the Rhetoric of Science in Britain, 18301917," in The Politics and Rhetoric of Scientific Method, ed. John Schuster and Richard R. Yeo, D. Reidel, Dordrecht and Boston.

Young, Allyn A., (Mar. 1926), "Economics and War: A Presidential Address," American Economic Review, Vol. 16, No. 1, pp. 1-13.

Zeizer, Viviana, A., (1994), The Social Meaning of Money, Basic Books, New York. Ziman, John, (1976), The Force of Knowledge, Cambridge University Press, Cambridge. 